\title{
RechtSpreken : mensenrecht in openbare orde
}

\author{
Citation for published version (APA):
}

Bost, R. (1999). RechtSpreken : mensenrecht in openbare orde. [Doctoral Thesis, Maastricht University]. Datawyse / Universitaire Pers Maastricht. https://doi.org/10.26481/dis.19990111rb

Document status and date:

Published: 01/01/1999

DOI:

10.26481/dis.19990111rb

Document Version:

Publisher's PDF, also known as Version of record

\section{Please check the document version of this publication:}

- A submitted manuscript is the version of the article upon submission and before peer-review. There can be important differences between the submitted version and the official published version of record.

People interested in the research are advised to contact the author for the final version of the publication, or visit the DOI to the publisher's website.

- The final author version and the galley proof are versions of the publication after peer review.

- The final published version features the final layout of the paper including the volume, issue and page numbers.

Link to publication

\footnotetext{
General rights rights.

- You may freely distribute the URL identifying the publication in the public portal. please follow below link for the End User Agreement:

www.umlib.nl/taverne-license

Take down policy

If you believe that this document breaches copyright please contact us at:

repository@maastrichtuniversity.nl

providing details and we will investigate your claim.
}

Copyright and moral rights for the publications made accessible in the public portal are retained by the authors and/or other copyright owners and it is a condition of accessing publications that users recognise and abide by the legal requirements associated with these

- Users may download and print one copy of any publication from the public portal for the purpose of private study or research.

- You may not further distribute the material or use it for any profit-making activity or commercial gain

If the publication is distributed under the terms of Article $25 \mathrm{fa}$ of the Dutch Copyright Act, indicated by the "Taverne" license above, 
Rech t Spreken

Mensenrecht in openbare orde 
Foto's onsslag:

voor: "The Kid", Charles Chaplin (1921) achter: Het Limburgs Dagblad,

Rie als Charlie's Angel in de carnavalsoptocht in Kerkrade (1978) 
Rechtspreke n

Mensenrecht in openbare orde

\section{PROEFSCHRIFT}

ter verkrijging van de graad van doctor aan de Universiteit Maastricht,

op gezag van de Rector Magnificus, prof. dr. A.C. Nieuwenhuijzen Kruseman,

volgens het besluit van het College van Decanen, genomen op 11 januari 1999

door

Rie Bost

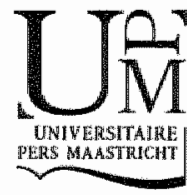


Promotores.

Prof Mr. N.H.M. Roos

Mr. M. J. Cohen

Beoordelingscommisste:

Prof. Mr. drs. G.E. van Maanen (voorzitter)

Prof. Mr. C. Flinterman

Prof. Mr. G.R. de Groot

Prof. Mr. D.H.M. Meuwissen (Rijksuniversiteit Groningen)

Prof. Mr. A.Q.C. Tak 


\section{Voorwoord}

Het boek is af. Na ruim tien jaar hard werken, veel lezen, schrijven en stevig discussiëren ligt er nu een werk dat als proeve van bekwaamheid is goedgekeurd voor het verkrijgen van de doctorstitel.

Je persoonlijke geschiedenis tekent de totstandkoming van dit boek. Steeds gesteund door je promotor-van-begin-af-aan Job Cohen en door je man Jo en je kinderen Britta, Bart en Kara, heb je voortdurend doorgewerkt, ook al zat het soms niet mee. In 1996 word je ziek, maar dat belet je niet on na een tijd de draad van het onderzoek weer op te pakken. Daarnaast werk je als docent/tutor aan de Maastrichtse juridische faculteit.

In de loop van 1998 word je opnieuw - ernstig - ziek. Het lijntje met het proefschrift wordt well heel dun, totdat Nico Roos, die als jouw woornaamste begeleider in de latere fasen van het onderzoek is opgetreden, de hoofdstukken van het tweede deel van het boek naar inhoudsdeskundige collega's stuurt. Na bemoedigende reacties van thun zijde, kruipt hij achter de computer om nog wat te sleutelen aan het eerste deel, en met name in het vierde hoofdstuk de samenhang aan te brengen zoals die in jullie onderlinge discussies al min of meer was vastgesteld. Jullie bespreken zijn aanpassingen. Je leest het manuscript nog eens door en geeft het dan, met wat opmerkingen die slechts kleine wijzigingen betreffen, uit handen.

Na de goedkeuring door de beoordelingscommissie wormen Nico Roos en wij, je paranimfen, een team en gaan aan de slag om die dingen te doen die horen bij de afronding van een proefschrift: voorwoord, nawoord, samenvatting, Synopsis, literatuurlijst, notenapparaat, tikfouten, drukker. Daarbij wordt het werk in beperkte mate geactualiseerd. De lezer zal merken dat tot en met 1995 veel literatuur en voorbeelden in de tekst zijn werwerkt. Daarna zijn slechts de verwijzingen naar handboeken in de noten bijgewerkt tot recente drukken. Secretariële hulp komt van Monique Destreel van de capaciteitsgroep Metajuridica, die het werk camera-ready maakt. Je familie draagt zorg voor de mooie omslag en Uitgeverij Datawyse levert buitengewoon snel werk. Namens jou bedanken wij iedereen die aan het verschijnen van dit boek een bijdrage heeft geleverd. Een bijzonder woord van dank gaat nog uit naar Alma van Bers, die je vanaf het begin van je studie uitdaagde om rechtsfilosofische onderwerpen aan te pakken.

We feliciteren je, vanuit een diepe verbondenheid in collegiale wriendschap wan harte met het afronden van je boek en het behalen van de titel.

Elsloo/Maastricht, januari 1999

Annemiek Derks

Ria Wolleswinkel 



\section{Inhoudsopgave}

\section{Deel I Mensenrecht en discursieve rechtvaardigheid}

\section{HOOFDSTUK 1 INLEIDING}

1. Een onderzoeksthema dient zich aan

2. De kwestie Geertruidenberg: is dit recht?

3. Begrippen: Recht, rechtsorde en rechtsidee

4. Openbare orde als algemeen inzetbaar rechtsbegrip : 7

5. Mensenrecht als morele kern wan recht 9

6. Overzicht wan de opbouw van dit boek 11

HOOFDSTUK 2 OP ZOEK NAAR EEN THEORETISCH KADER

1. Een gespreksmodel van recht

2. Barendrecht: recht als model van rechtvaardigheid 14

3. Bespreking van Barendrechts theorie 1.5

4. De vraag naar het primat: mensenrecht of democratie? 19

5. Ideeënhistorische voedingsbodem voor interne samenhang 20

6. Publieke autonomie en de morele kern wan het recht $\quad 24$

HOOFDSTUK 3 RECHT "SPREKEN"

$\begin{array}{ll}\text { 1. Inleiding } & 27\end{array}$

2. Private en publieke autonomie... 27

3. ...een niet operationeel te maken concept? 29

4. De samenhang van private en publieke autonomie met 31 politieke macht 31

5. Openbaarheid 33

6. Openbaarheid en gesprek in de rechtszaal 36

7. Dimensies van rationeel handelen 41

8. De ontkoppeling van systeem- en leefwereld in liet recht 44 
HOOFDSTUK 4 IN ALPARTIJDIG PERSPECTIEF: DRIE BEGINSELEN VAN MENSENRECHT

1. Inleiding

2. Alpartijdig stellen en toepassen van rechtsnormen 45

3. Alternatieve concepties van alpartijdigheid 48

4. Bruggen tussen private en publieke autonomie $\quad 52$

5. Drie beginselen wan rechtens behoorlijk handellen 55

6. Drie beginselen wan mensenrecht 58

\section{Deel II Mensenrecht em openbare ordle in het Nederlands recht}

\section{HOOFDSTUK 5 INTERNATIONAAL PRIVAATRECHT}

1. Inleiding

2. Opkomst van het openbare orde begrip in het ipr

3. "Eenige opmerkingen..." uit 1895

4. Na 1895: via zedelijke en algemene rechtsbeginselen...

5. en in samenhang thet voorrangsregels...

6. nawr doorwerking van drie beginselen van mensenrecht

7. Openbare orde als ingang voor toetsing van vreemd recht aan het Europees mensenrechtenverdrag?

8. Openbare orde als laatste kwaliteitstoets in het ipr

\section{HOOFDSTUK 6 PRIVAATRECHT}

1. Inleiding

2. Ontstaan van het Nederlandse privaat- en publiekrecht

3. Het begrippenpaar openbare orde en goede zeden in het contractenrecht

4. Doorwerking van moraal via het begrippenpaar openbare orde en goede zeden

5. Drie beginselen van contractenrecht en drie beginselen van mensenrecht: een vergelijking

6. Doonwerking van drie beginselen van mensenrecht in drie fasen: voor, tijdens en na het sluiten van het contract 


\section{HOOFDSTUK 7 PUBLIEKRECHT}

1. Inleiding

2. Het openbare orde begrip in het verengingsrecht van politieke partijen

3. Algemene beginselen van behoorlijk bestuur in verhouding tot drie beginselen van mensenrecht

4. Het politiebegrip openbare orde

5. Misdrijven en overtredingen betreffende de openbare orde en de zeden in het Wetboek van Strafrecht

\section{HOOFDSTUK \& INTERNATIONAAL PUBLIEKRECHT}

1. Inleiding

2. De ontwikkeling van de vrijheid van geweten tot klassiek mensentecht

3. Zet "oeverloosheid" van het geweten het vrijheidsbeginsel opzij?

4. Drie beginselen van mensenrecht als hulpmiddel bij het opheffen van de tweedeling in klassieke en sociale mensenrechten?

5. Staatsverplichtingen: uitbanning van rassendiscriminatie tegenover respect voor uitingsvrijheid van journalisten

6. Een universele bemiddelende functie van het begrip openbare orde ten aanzien van mensenrecht

7. Mensenrecht in de context van Europees Gemeenschapsrecht

8. Openbare orde in de context wan Europees Gemeenschapsrecht

\section{HOOFDSTUK 9 EEN RICHTSNOER VOOR IEDER?}

1. Inleiding

2. Samenvattende vergelijking Nederlands recht

3. Houdbaarheidstest in Nederlands recht geslaagd

4. Een proef met de kwestie Geertruidenberg: is dit recht?

5. Drie beginselen van mensenrecht als universeel richtsnoer voor ieder in een wereldorde in wording? 
Inhoudsopgave

Samenvatting

Synopsis

Literafuurlijst

181

Nawoord

189 
DEEL I

MENSENRECHT EN DISCURSIEVE RECHTVAARDIGHEID 



\section{INLEIDING}

\section{Een onderzoeksthema dient zich aan}

In 1982 had ik als bijna vijftigjarige het genoegen te behoren tot de eerste lichting van de in dat jaar in Mastricht gestarte juridische faculteit. Vol enthousiasme en verwachting begonnen wij aan de "revolutionaire" opleiding van deze nieuwe faculteit. lk viel, zo weet ik nu, met mijn neus in de juridische boter. Volgens een probleengestuurde afspraak met medestudenten las ik ter kennismaking met jurisprudentie een uitspraak van de Hoge Raad dic bekend staat als het tweede Geertruidenberg-arrest." Het arrest verbaasde mij in hoge mate en boeide mij aanzienlijk meer dan overeenkwam met de overige in de onderwijsgroep aanwezige belangstelling en met de voor bespreking beschikbare tijd. Job Cohen was tutor in die onderwijsgroep. "We kumnen er nog wel een keertje over praten", zei hid terloops in de wandelgang na afloop van de bijeenkomst. Dat was het begin van een reeks kostelijke discussies door de jaren heen, zowel voor als na de voltooing van mijn studie.

Ondat "Geertruidenberg" het onderzoek op gang heeft gebracht en om de lering die er uit te trekken valt, wordt deze strafzaak in de volgende paragraaf kort besproken (par. 2). Bij eerste lezing riep het Geertruidenberg-arrest bij mij de vraag op: is dit recht? Dic vraag had niet veel te maken met de formele technisch-juridische kwaliteit van de uitspratk. Ze had vooral te maken met inhoudelijk-morele kwaliteit. Anders gezegd: hel ging niet on de legaliteit maar om de legitimiteit van de uitspraak van de rechter. Na de verbazing rond het tweede Geertuidenberg-arrest kreeg de tem openbare orde voor mij een signaalfunctie voor de problemen met betrekking tot orde en rechtwaardigheid. "Openbare orde" leek een soort toverspreuk warmee taaltovenars in het rechtsbedrijf praktisch elke gewilde richting uit kunnen. Daarbij leek het ordeperspectief nogal eens te domineren ten koste van rechtvaardigheid." Dat heef in dit onderzoek geleid tot een opvalting wan het begrip recht (par. 3) die beide kanten omvat en warin de spanning te onderkennen is tussen "rech" en "orde" zoals die begrippen in de centrale onderzoeksthese gebruikt worden.

De centrale these vart dil onderzock luidt als volgt. $\mathbb{E} r$ is een morele kern van recht aan te wijzen die dienst kan doen als richtsnoer voor een niek alleen legale maar ook legitieme interpretatie van (openbare) orde in een democratische rechtsorde. Deze morele kem cor-

2 Tegen het einde van de studie schreef ik onder begeleiding van Alma van Bers en Job Cohen ex artikel met als titel "Openbare orde: een toverspreuk" en als onderitel "Beschouwingeri naar aanleiding van de Geetruidenberg-arresten". Zie Moastrichtse wandelingen door hor Rech, 10 scriphes van de eerste lichting afgestudeerden an de Faculteit der Rechtsgeleerdheid te Mastricht, septenber 1986, p. 6-20. 
respondeert met presupposities van het menselijk discours zoals geanalyseerd door Jurgen Habermas. Deze discursieve rechtvaardigheid is ten nawwste verbonden met de idee van de wiversele mensenrechten en ik duid hem daarom ook aan als mensenrecht. In het tweede deel van deze studie zal de praktische houdbaarheid van een in het eerste deel te ontwikkelen richtsnoer worden getest in het Nederlandse recht.

De notie "mensenrecht" is wellicht niet de eerste associatie die door de tem openbare orde zal worden opgeroepen. Bij de term openbare orde denkt men onwillekeurig aan ordehandhaving zelfs al zou dat ten koste gaan van mensenrechten, bijwoorbeeld waneer de politie optreedt bij wanordelijkheden. Toch zal uit deze studie bliken dat beide noties ten nauwste met elkaar verbonden zin. Om dat voorlopig enigszins plausibel te maken zeg ik het een en ander over de algemene inzetbarheid wan het politiek-juridische begrip openbare orde (Stelling I; par. 4). In de daarop volgende paragraal (par. 5) zet ik uiteen hoe de notie mensenrecht refereert aan de morele kern van het modeme westerse recht (Stelling $\mathrm{C}$ ).

In de afsluitende paragraaf van deze inleiding wordt aangegeven hoe het betoog verder zijn beslag krijgt (par. 6 ).

\section{De kwestie Geertruidenberg: is dit recht?}

Alleen al het bestaan van de Geertuidenbergse kwestie als strafzalk deed mij als eerstejakrs rechtenstudent in 1982 gekunsteld aan, om nog maar te zwijgen van de wijze waarop de Hoge Raad de kwestic afdeed. Juridisch ging het om een eis van openbare orde als "noodzakelijke" beperking van de uitoefening van "de openbare godsdienst" als mensenrecht. Feltelijk kwam de eis van openbare orde neer op een aan de Nederlandse grondwet ontleend verbod om in de Noord-Brabantse plats Geertruidenberg een rooms katholieke processie te houden. Verbazingwekkend voor mj was dat de "noodzaak" wan het zogenaande processieverbod niet werd aangetoond met het oog op de lokale toestand in de tijd warin de processie gehouden werd, dat wil zeggen de toestand in de plaats Geertruidenberg in het jaar 1957. Nee, deze "noodzaak" werd beredeneerd met het oog op plaatselijke gebruiken die wia een grondwetsbepaling uit 1848 teruggevoerd werden tot 1795 en eerder. Met een in mijn studentenogen bizare vasthoudenclheid werd deze strafzaak door het openbaar ministerie tot in hoogste nationale rechtsinstantie gevoerd in een geschil dat eenvoudig niet in het tolerante Nedenland wan de hweede helft van de Iwintigste eeuw leek to passen. Als sluitstuk bleek de Hoge Raad bereid een mij bizar voorkomende openbare orde-formule uil te spreken. Als gevolg darvan bleef de eis van het openbaar ministerie betreffende de openbare orde overeind en falde het beroep van de verdachte op het mensenrecht. Mijn vraag was: is dit recht?

Zic hier de toedracht. Een kapelaan van de rooms-katholicke St. Gertudisparochie te Geertuidenberg houd op 23 juni 1957 aldaar een openbare godsdienstoefening in de vorm van een door hem georganiseerde processie. Een strafrechtelijke vervolging tegen de kapelaan is het gevolg. Volgens de tenlastelegging heeft hij "de R.K. openbare godsdienst uitgeoefend op ecn andere plats of op andere platsen, dan was de openbare godsdienstoefening, naar art. 184 lid 2 (art. 107 lid 2 oud) der Grondwet volgens de bij de uitvandiging der Grondwet wan 1848 bestande wetten en reglementen was toegelaten." De 
kapelaan roept artikel 9 van het voor Nederland in 1954 in werking getreden Europees verdrag tot bescherming van de rechten van de mens en de fundamentele vrijheden (EVRM) in, dat dateert wan 4 november 1950 . Volgens de tekst van artikel 9 lid 2 EVRM is een beperking van de in het eerste lid neergelegde godsdienstvrijheid slechts toegelaten als die niet alleen bij wet is voorzien in een democratische gemeenschap, maar ook "noodzakelijk" is voor de bescherming van de openbare orde.

De Rechtbank Breda komt aan het beroep op artikel 9 EVRM niet toe. Bij vonnis van 25 februari 1958 wordt de verdachte kapelaan vrijgesproken. ${ }^{3}$ De rechilbank oordeelt dat het openbaar ministerie niet geslaagd is in het te leveren bewijs dat in 1848 de openbare godsdienstoefening in Geertruidenberg niet gebruikelijk was. Op 9 december 1958 bevestigt het Hof 's-Hertogenbosch in hoger beroep de uitspraak van de rechtbank. Op 15 mei 1959 vernietigt de Hoge Raad de uitspraak van het Hof op grond van onzuivere vrijspraak en verwijst de zaak voor afdoening naar het Hof Arnhem. ${ }^{4}$ De Hoge Rat overweegt onder andere "dat, waar het Hof te dezen slechts beslissend heeft geacht de vraag, of bewezen is dat in de gemeente Geertruidenberg in 1848 de openbare godsdienstoefening, in den ruimsten zin genomen, buiten gebouwen en besloten plaatsen niet gebruikelijk was, en het Hof daarnevens nog slechts heeft overwogen dat ook geen enkel bewijs geleverd is aangaande den plaatselijke feitelijke toestand en deszelfs gebruiken te Geertruidenberg in 1822 , het college aan de hierboven uit de te laste legging angehaalde woorden een onjuiste betekenis heeft toegekend."

Om de processie in Geertruidenberg als geoorloofd te kumnen beschouwen is volgens de Hoge Raad niet alleen nodig dat die vorm van godsdienstoefening bij de uitvaardiging van de Grondwet 1848 in die gemeente gebruikelijk was, maar ook "dat dit gebruik steun vond in het Besluit van 23 april 1822, met andere woorden dat plechtigheden van dien bepaalden vorm te Geertruidenberg tot 1822 "zonder interruptie altijd" - zowel voor als na 1795 - hebben plaats gehad." Door niet verder terug te denken dan 1822, is her Hof volgens de Hoge Raad tekort geschoten.

Hoe vait een overweging over oeroude gebruiken met voorbijgaan alan de reële plaatselijke situatie in 1957 te rijmen met een moderne verdragseis als die van artikel 9 lid 2 EVRM? Een eis van openbare orde moet volgens dat artikel toch "noodzakelijk" zijn on een beperking van de godsdienstvrijheid te rechtvaardigen? In zijn eerste arrest kontt de Hoge Raad aan een antwoord op deze vragen nog niet toe.

Na de verwijzing door de Hoge Raad klaart het Hof Arnhem het toetsingskarwei in een uitspraak van 8 maart 196.. Het Hof stelt het grondweltelijk processieverbod buiten werking als onverenigbaar met artikel 9 EVRM en ontslaat de verdachte van rechtsvervolging. Het Hof oordeelt dat de in het tweede lid wan artikel 184 Grondwet neergelegde beperking niet geacht kan worden noodzakelijk te zijn voor de openbare orde. 


\section{Hoofdstuk I}

En dan komt hel tweede Geetruidenberg-arrest. Daarin draait de Hoge Raad de beslissing wan het Hof Arnhem terug, tegen het advies van de procureur-generall Langemejer in. De Hoge Raad makt daarbij gebruik van de volgende loetsingsformule. Alleen dán mag de rechter volgens de Hoge Raad een beperking van de vrijheid van godsdienst door de wetgever als niet noodzakelik voor de bescherming van de openbare orde beschouwen "indien het ten enen male ondenkbaar zou moeten worden geachi dat en wetgever, gesteld voor de noodzatk met het oog op de bescherming van de openbare orde te dien aanzien. een regeling te treffen, daartoe cen zodanige regeling in redelijkheid zou kumnen treffen of handhaven."

Als beginnend rechtenstudent wist ik niet dat ik te maken had met een omstreden staalije Nederlandse jurisprudentie. Ik dacht: waróm laat de Hoge Raad die mensen met hun mensenrecht in de kou staan? Voor hel ordelijk verloop van het gemeenschapsleven in Geertruidenberg is en strafvervolging op grond van het oeroude processieverbod ongetwijfeld nict nodig en juridisch gezien stat artikel 9 EVRM de rechter als "hoger" recht ter beschikking on het processieverbod buiten werking te stellen. Ik dacht verder: de toepasing ervan is niet "noodzakelijk" maar de rechter is kennelijk niet bereid het processieverbod buiten toepassing te verklaren. De consequentie dat het in het EVRM gewarborgde mensentecht dan geen bescherming bied neemt de rechter op de koop toe. En tenslotte dacht ik: de toverspreuk die de rechter deze keuze biedt in dit taalspel dat rechtspraak heet is: "openbare orde".

Met de intussen bereikte distantie is niet alleen mijn verbazing begrijpelijk, maar ook de terughoudendheid van de Hoge Rad wat betreft de toepassing van het Europees mensenrechtenverdrag. Dat het processieverbod als eis van openbare orde niet in een gewone wet maar in de grondwet verpakt zat, heeft de Hoge Raad uiteraard parten gespeeld. In 1962 was toetsing van een bepaling van de hoogste nationale wetgever - en dan nog wel een bepaling met een historisch gewicht als het processieverbod - aan een piepjonge verdragsbepaling voot de Hoge Raad een onwennig karwei.

In het licht van de klassieke scheiding van overheidsmachten leek het toepassen van een internationale verdragsbepaling door de rechter ten koste van een bepaling van do nationale grondwet in die tijd wellicht heiligsehennend. In de ogen van de rechter kon het rachtsbelang van een processie in het Noond-Brabantse Geentruidenberg daar kennelijk niet tegenop. Dat de houding van de Hoge Raad achteraf gezien begrijpelijk is, wil achter nog niet zeggen dat deze achteraf ook goed te praten valt. Maar er is méér.

Opmerkelijk is dat het processiewerbod pas in 1983 uit de Nederlandse grondwet en - in verband met uitwoeningswetgeving - pas in 1988 uit het Nederlandse rech is werdwenen. Laten we aamemen dat het processieverbod in 1815 nodig was, gelet op de toen gevoelige geloofsverhoudingen tussen protestanten en katholieken in dit land. Tegen welke tijd had het dan als grondwettelike maatregel van openbare orde realiter geschrapt kunnen worden? De grondwetsherziening in 1848 kont daatvoor niet in anmerking. Ook bij de grondwetsherzianing in 1917, toen tijdens de eerste wereldoorlog een "godswrede" de pacificatio van openbar en bijzonder onderwijs mogelijk makkte, was politiek Nederland er blijkbaar niet an toe om het processieverbod uit de grondwet te halen. 
Na de tweede wereldoorlog, rond de tijd van de Universele Verklaring van de rechten wan de mens (1948) en het mede daardoor geinspireerde Verdrag van Rome, het EVRM (1950), moet de tijd ongetwijfeld wél rijp zijn geweest om het processieverbod uit de grondwet te halen en als museunstuk bij te zetten. Dat het ook dan nog tientallen jaren met grondwettelijke status kon blijven voortbestaan zou eenvoudig toegeschreven kunnen worden aan het feit dat het politiek niet interessant was en aan het tijdrovende van een herziening van de grondrechtencatalogus die leidde tot de grondwetsherziening 1983. Het vervallen van het processieverbod was een onderdeel van die herziening.

Leerzaam vind ik het, te constateren dat in een tijd waarin een regel niet alleen duidelijk "uit de tijd" is, maar het met het oog op een nieuwe regel ook voor de hand ligt om ze buiten toepassing te laten, gezagsdragers te vinden zijn die bereid zijn verbaliserend, vervolgend en rechtsprekend zo"n achterhaalde bepaling "in rechte" zijn werk te laten doen. In rechte? Mijn vraag blijft: is dit recht?

\section{Begrippen: recht, rechtsorde en rechtsidee}

Volgens Meuwissen zijn de belangrijkste kenmerken van recht: a) het tot stand brengen van recht door daartoe bevoegd gezag; b) de algemene gelding; c) de gerichtheid op uiterlijk waameembaar menselijk gedrag; d) de kenbaarheid, algemeen-toegankelijkheid en rationaliteit van recht; e) de formele structuur; f) de rechtsidee. ${ }^{6}$ Op elk van deze kenmerken ga ik hierna kort in.

Ad a) Het proces van rechtsvorming en rechtshandhaving wordt op gang gehouden door daartoe bevoegd gezag. Het bevoegd gezag, de overheid met als overheidsorganen wetgever, rechter en overheidsbestuur, wordt door het recht bimen een rechisstelsel aangewezen en georganiseerd en is zelf ook aan het recht gebonden.

Ad b) Met de gelding van recht is de aanspraak bedoeld op algemene verbindendheid van het recht. In die aanspraak kan onderscheid gemakt worden tussen drie facetten van gelding: de saciale, de juridische en de morele gelding. ${ }^{\top}$ Deze drie facetten maken in onverbrekelijke samenhang de normatieve gelding van het recht wit. Sociale gelding wil zeggen dat het recht feitelijk wordt toegepast en nageleefd. Juridische gelding betekent dat het recht op een door het recht zelf geregelde manier is tot stand gekomen. Dit facet van gelding komt overeen met het begrip legaliteit. De morele gelding betreft de eerder al ter sprake gekomen legitimiteit, het moreel gerechtvaardigd zijn van recht.De algemeenheid van de gelding van recht betekent dat het voor overheidsgezag en burgers binnen een rechtsorde gelijkelijk verbindend is.

6 D.H.M. Meuwissen, Recht en wijheid, Inleiding in de rechtsfilosofic, Utrech/Antwerpen 1982 , 13 $v$

7 Zie Meuwissen 1982 , p. 216, die voor de drie geldingsmomenten verwijst nat R. Dreier, "Rech und Moral", in Recht, Moral, Ideologie 1981, p. 180. 
Ad c) Recht doen is gericht op het reguleren wan uiterlijk waameembaar menselijk. gedrag. Dat wil niet zeggen dat persoonijke opvattingen en gevoelens van mensen door het recht nooit beschermo worden. Integendeel, denk maar aan de mensenrechtelijke erkenning van de wrijheid van geweten, godsdienst en levensovertuiging. Waar het om gat is dat de regulerende taak van het recht niet verder gaat dan uiterlijk wameembaar gedrag; ongeacht door welke geestelijke instelling dat gedrag geînspireerd is.

Ad d) Kenbaarheid, algemeen-toegankelijkheid en rationaliteit zijn kenmerken die naw samenhangen met de algemene gelding van recht. Naarmate recht minder bekend en toegankelijk is en minder vrij van willekeur, kan het in de praktijk moeilijker door ieder toegepast en nageleefd worden. Recht drijft als het ware op een openbaarbeid waarin rationeel geregelde procedures voorzien in rationele argumentaties en afwegingen voor het behandelen of oplossen van maatschappelijke problemen.

Ad e) Op haar beurt hangt de formele structuur van het recht nauw samen met de kenbaarheid, algemeen toegankelijkheid en rationaliteit van het rechtsstelsel als geheel. Globaal kan onderscheid worden gemaakt tussen rechtsnormen (zoals wettelijke regels en rechterlijke beslissingen), rechtsfiguren of rechtsinstituties (zoals eigendom of contract) en rechtsinstituten (zoals verenigingen).

Ad f) Met uitzondering van de morele legitimiteit ais éen van de drie facetten van gelding (zie onder b), hebben alle hiervoor besproken kenmerken van recht betrekking op proceclurele en structurele kanten van recht. In termen van recht en orde in een rechtsorde zou je dat de formeel ordenende kant van recht kunnen noemen. De rechtsidee daarentegen heeft betrekking op de inhoudelijk ordenende kant van recht. Preciezer gezegd verwijst de rechtsidee naar de pretentie die het recht als geheel heeft on een bepaald einddoel te verwerkelijken. Op dat finale doel ga ik in deze korte bespreking van kenmerken van recht nog niet nader in. Voldoende is hier de constarering dat de morele gelding van recht direct betrokiken is op de rechtsidee.

Formeel-technisch dient recht voor het in stand houden van cen uiterlijke ordening van menselijk samenleven volgens een in recht uitgedrukt organisatiepatroon. Zo gezien correspondeert de component "orde" in het begrip "rechtsorde" met de formeel-technische aspecten van recht. On volwaardig als "recht" te kunnen gelden moeten uiterlike ordening en het organisatiepatroon daatachter echter niet alleen op de aspecten feitelijke en tech. nisch-juridische gelding matar ook op het aspect morele gelding betrokken zijn. Wat feitelijk of technisch-juridisch aan rechtsordening wenselijk of nodig lijkt kan in strijd zijn met de rechtsidee. Daardoor kan deze ordening morele gelding ontberen en daarmee als rechisordening te kort schieten. Via deze studie over openbare orde en rechtvaardigheid, wil ik pogen tot een nadere bepaling te komen van de rechtsidee zodanig dat er een praktisch richtsnoer kan worden gehanteerd om te controleren of beide elementen van de term rechtsordening de juiste nadruk hebben gekregen. Dit richtsnoer, dat ontwikkeld wordt in het eerste deel wan deze studie, bestast uit drie beginselen: wrijheid, trouw en zorg. Via de analyse van de ontwikkeling van thet begrip openbare orde in het Nederlandse recht zal blijken dat ook het begrip "openbare orde" alleen als rechtsbegrip adequat kan 
worden begrepen als het ordenende aspect van het recht word onderworpen an deze drie morele beginselen.

\section{Openbare orde als algemeen inzetbaar rechtsbegrip}

Stelling 1: "Het begrip opewbre onde is als kwalificatie van dwingend recht in beginsel in iedere rechtsregel of rechtsbeslissing toe te passen."

In dit stadium van het betoog zou ik de stelling ook kmmen vereenvoudgen tot de bewering dat de uitdrukkingen "dit is van openbare orde" en "dit is dwingend recht" in het Nederlandse recht synoniem zijn. Daarbij wil ik het niet laten. Met een korte algemene plaatsbepaling en enkele voorbeelden uit het Nederlandse recht wordt de stelling hier alvast wets nader toegelicht.

In het begrip openbare orde komt uiterlijke ordening als oerfunctie van recht tot uitdrukking. Deze functie rakt de meest essentiele grenzen van en binnen een rechtsorde en daannee de kemproblemen van recht. Extern gericht markeert het begrip de grenzen van bimnen een rechtsorde geldend recht. Zo kan een nationaal georienteerd openbare orde begrip in het internationaal privaatrecht functioneren als effectief afweemiddel tegen veemd recht." En moetzame discussies over intemationalisering van openbare orde begrippen binnen de Europese Gemeenschap lopen parallel met een even moeizame ontwikkeling van een Europese rechtsorde zelf." Intern, binnen een rechtsorde, raakt het begrip openbare orde eveneens wezenlijke grenzen, zoals die tussen het publieke en het private en die tussen dwingend techt en anvallend recht.

In het Nederlandse recht heeft het begrip openbare orde uiteenlopende betekenissen. Die betekenissen varièren van het ordelijk verloop van het alledaagse leven op straat of ander openbaar terrein tot een samenvallen van openbare orde met rechtsonde, van trivialiteiten in het leven van alledag tot de als meest fundamenteel gedachte beginselen van de sociale en democratische rechtsstaat. Global zijn twee soorten betekenissen aan te geven. De ene soort betreft zeer veetzijdge, maar per geval beperkte, an en concrete context gobonden betekenissen. De andere soort heeft betreking op de rechtsorce als geheel.

De aloude politietak tol hel handhaven van de openbare orde lijkt de neest duidelijke toepassing van het begrip openbare orde in beperkte, feitelije contexten. Maar wat rest nog van die duidelijkheid als blijkt dat de poltietaak sterk verweven is met besturlijke hanchaving van de rechtsorde als geheel? ${ }^{10}$

In thet privatrecht is het contract als private rechtshandeling een klassuck voorbecld wan de rekbarheid van het begrip openbare orde (en goede zeden), als instrument in handen van

8 Zie hidst. 5

97 ze lifdst. 8. par. 7 eng.

10 Zichtost. 7, par. 4 


\section{Hoofdstuk I}

de burgerlike rechter. Bij de inwoering van het Burgerlijk Wetboek in 1838 werd bepaald dat een owercenkomst niet in strijd mag zijn met de openbare orde en de goede zeden. De interpretatie van dit begrippenpar in de loop van de tijd weerspiegelt fraai de evolutie van de contractsvrijheid in de zich van klassick liberaal tof verzorgingsstaat ontwikkelende Nederlandse rechtsstaat"

Dat het begrip openbare orde en sleutelpositie kan imnemen bij problemen die het democratisch functioneren van de rechisstat raken, illustreent de geschiedenis van de verenigingsvrijheid van politieke partijen. Bij het grondrecht tot vereniging functioneert het begrip openbare orde vanouds als beperkingscriterium. Maar ook de meer recente geschiedenis van de Wet van 17 maart 1988 inzake "verboden rechtspersonen" laat zien hoe zich tot in onze tijd hevige dilemma's in partementaite discussies afspelen rond het begrip "openbare orde". Dic bewogen geschiedenis laat óok zien hoe ondanks of juist dankzij hevige controverses het open begrip openbare orde als criterim tar bepenking wan het recht tot vereniging gehandhaard wordt. ${ }^{2}$

Het materiele strafrecht kan als een met directe sanctiedreiging opgelegde en gehandhaafde publieke ordening in zijn geheel worden opgevat als openbare orde in de zin wan dwingend recht. En het Nederlandse strafprocesrecht telt een groot aantal procesregels die "van openbare orde" zijn, dat wil zeggen dat ze wegens hun functie als warborg woor een deugdelijk proces van dwingende aard ziji. ${ }^{13}$

Als passend sluitstuk van het voorlopig aanmemelijk maken van de algemene juridische inzetbarheid van het begrip openbare orde volgt hier een passage uit hel parlementair debat rond het verdwijnen van het eerder besproken processieverbod uit de Nederlandse grondwet. In dat debat gat het over nieuwe criteria ter beperking van de vrijheid van godsdienst en levensbeschouwing. De Raad van State is weinig gelukkig met "gezondheid, verkeer en wanordelijkheden". Vooral "verkeer" als mogelijke beperking van een grondrecht, vindt de Raad niet fraai. Hij geeft in overweging te volstaan met: "De wet kan regels stellen ter handhaving van de openbare orde." Daar zou volgens de Raad het verkeer zo nodig onder vallen. ${ }^{*}$

In thun commentaar geven de verantwoordelike ministers als hum ming te kennen dat het voorstel van de Raad van State cen anmerkelijke uitbreiding van de beperkingsbevoegdheid en dus een verzwakking wan het grondrecht zou inhoullen. Dan volgt deze passage: "Het begrip "openbare orde" is er een, dat zich bijzonder ruim lat uitleggen." Nagenoeg we beleidsdoeleinden laten zich eronder brengen (...). Hantering wan een begrip als Wanordelijkheden is veel duideliker en verdient, waar nodig aangevuld met andere beperkingsgronden, nat onze mening de voorkeur." De ministers hebben gelijk. Het begrip openbare orde is er inderdaad een dat zich bijzonder nim laat witleggen, zodat "nagenoeg

Zie hidst 6

Zie hifdst. 7, par, 2.

Zie hrosi, 7, pux, 5 .

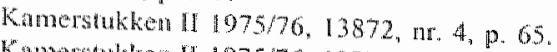

Kanterstuken II 197576,13872, nr. 6, p. 31. 
alle beleidsdoeleinden" eronder te brengen zijn. Sterker nog: het woord "nagenoeg" kan wat mij betreft uit het citaat vervallen, zodat niet "nagenoeg alle", maar "alle" beleidsdoeleinden in het begrip openbare orde zijn onder te brengen. Deze gedachte is wat het begrip openbare orde betreft het uitgangspunt van mijn betoog.

\section{Mensenrecht als morele kern van recht}

Stelling II: "De notie mensenrecht onvat de morele kern van recht naar westerse traditie."

In deze stelling gaat het over de notie mensenrecht. Daarmee wil ik duidelijk maken dat het niet gaat om mensenrecht in een betekenis van concreet geldend recht zoals dat in internationale verdragen of nationale wetten te vinden is. Het gat on de idee mensenrecht, die als invulling van de eerder besproken rechtsidee de morele gelding van iedere specifieke juridisering van rechten van de mens bepaalt. Om de stelling voorlojig aamnemelijk te maken plaats ik de historische ontwikkeling van rechten van de mens tegen de achtergrond wan de beweerde algemene juridische inzetbaarheid van het begrip openbare orde.

Als eerder aangegeven is het ordenen en op orde houden van een menselijke samenleving als oerfunctie van recht herkenbaar in het politiek-juridisch begrip openbare orde. Ordenende macht is in iedere samenleving anwezig. Dat is niet alleen een ervarings:eit, het kan ook gezien worden als een zekere behoefte van mensen. Ordening kan zekerheid en daardoor bescherming bieden. Maar ordenende macht kan ók in de eerste plaats beschouwd en gebruikt worden in het belang van machthebbers zélf. Niet alleen degenen clie aan macht onderworpen zijn, ook machthebbers zelf hebben behoefte aan legitimatie van hun machtspositje. In een eerste juridische dimenisie in de Westerse traditie is dit het "recht" op regeermacht." Een tweede juridische dimensie is het "recht" van besturen, door middel van organisatie en de inzet van eer passend geacht instrumentarium. Een derde dimensie in de hier zeer grof geschetste ontwikkeling is juridische normering van de ordenende machtsuitoefening zélf. In deze dimensie is de vraag: wat doet het gezag door middel van zijn organisatie en instrumentarium en hóe doet het dat in een rechtsverthouding met de bestuurden? In deze fase gaat het om de rechtspositic van de burger ten opzichte van de owerheid.

De notie mensenrecht is aan de oppervlakte gekomen en uitgegroeid in vrijheidsbewegingen als reacties tegen overheidsmacht. Dat heeft geleid tot de ontwikkeling van klassieke grond- of mensenrechten, die als functie hebben on op vrijheid gerichte belangen varn leden van een samenleving tegen overheidsinmenging te beschermen. Dat daarbij vanouds de morele kern van vrijheid in het geding is geweest, daarvan getuigt de historische ontwikkeling wan de vrijheid van geweten. In 1579 heeft deze morele vrijheid in de Unie van Utrecht alls eerste de juridische status van mensenrecht bereikt. ${ }^{17}$

16 I. Yan der Hoeven, De drie dimensies van het bestumsrech, Alphen ad. Rijn 1989, p. I1 v.

17 Zie hedst. 8, par. 2 


\section{Hoofdsruk I}

In de historische ontwikkeling van klassicke rechten van de mens past het begrip openbare orde als een machtsinstrument dat overheden speelruinte geeft on zich wiet te onthouden, om in naam van het algemeen belang legaal inbreuk op rechten van de mens te kunnen maker. Het beeld van een zich zowel op het gebied van klassieke als op dat van sociale rechten van de mens actief inmengende overheid is na enkele wereldoorlogen een verschijnsel van onze tijd. Naar de mate waarin in de ordening van de samenleving de notie mensenrecht in gejuridiseerde vormen is doorgedrongen, heeft dit in inhoud en werking van het begrip openbare orde weerspiegeling gevonden.

Het overheidsoptreden en parallell daaraan het openbare orde begrip bestrijkt steeds meer ook situaties waarin sprake is van horizontale werking van rechten van de mens, tussen burgers onderling. Tenslotte bestrijkt het juridisch openbare orde begrip ook actieve overheidsinmenging bij het feitelijk verwezenlijken wan zowel klassieke als sociale rechten van de mens. In naam van openbare orde gaat dit desnoods ten koste van rust en veiligheid zoals die in een klassieke invulling van het openbare orde begrip werden opgevat. Denk bijwoorbeeld aam het zo nodig inzelten van een grootscheepse politiebescherming voor het waarborgen van wrijheid van meningsuiting bij een controversiële betoging. In een klassieke opvatting van het handhaven van de openbare orde zou het toelaten van zo'n betoging eenvoudig niet aan de orde zijn geweest.

Als in het begrip openbare orde tenslotte ook bescherming van burgers tégen de overheid tot uitdrukking koml - de eerder geschetste derde dimensie van juridische normering - dan is de cirkel van juridische inzetbaarheid van het begrip openbare orde in samenhang met rechten van de mens rond. In dit verband beschouw ik de term openbare orde in artikel 4. lid 2 van de Wet Persoonsregistraties - als uitwerking van het sedert 1983 in de Nederlandse grondwet opgenomen recht op bescherming van de persoonlijke levenssfeer - als een historisch moment in de juridisering van de spanningstelatie tussen openbare orde en mensenrecht in het Nederlandse recht. Ter bescherning van de beslotenheid van zijn persoonlijke levenssfeer kan de burger nu juist het bij uitstek publieke begrip openbare orde niet alleen tegen mede-burgers, maar ook tegen de overheid als zodanig in stelling brengen. Daarmee heeft de notie mensenrecht zich in een juridische uitwerking in de kem van het juridisch begrip openbare orde genesteld.

De geschetste ontwikkeling heef het oorspronkelijk probleem van bescherming van onderdanen tegen overheidsmacht niet wit de wereld geholpen, al kan geconstateerd worden dat onderdanen zich tot steeds mondiger wordende burgers ontwikkeld hebben. Geheel a tgezien van goede of minder goede bedoelingen ontstaan in nam van zorg, bescherming, berniddeling op het gebied wan rechten wan de mens nieuwe machtsafhankelijkheden waar evenwichtige machtsverdeling met gelijkwardige vrijheid voor ieder de inzet is. Bovendien ontstaat naast overheidsmacht ook groeiende overheidsonmacht. Dat wordt in de hand gewerkt door factoren als steeds verder gaande maatschappelijke democratisering en een internationalisering die het gevolg is van groeiend besef van afhankelijkheden in het licht van mondiale problemen. Het beeld dringt zich op van een onoverzichtelijke verwevenheid van machtscentra op uiteenlopende levensgebieden. Dat makt rechtsbescherming door en 
baar. Het kan hooguil in de loop van de tijd telkens weer vertald worden in een probleen wasn beter of minder goed mee te leven valt.

Met het oog op individuele rechtsbescheming lijkt het feit dat rechten wan de mens in gejuridiseerde vormen steds meer in het algemene juridisch begrip openbane orde tot uitdrukking komen op het eerste oog een onverdeeld prima ontwikkeling: het "machtige" begrip openbare orde kont steeds meer expliciet in diensi te staan van rechten van de mens. Maar zit hier niet een addertje onder het gras? Dreigt het moreel appel van de notie mensenrecht tot behoorlijk handelen in de samenleving niet op de achtergrond te raken nar mate deze notie in steeds meer alledaagse vormen juridisch "ingeliff" wordt in de ordenende macht van "openbare orde"? Dreigt daardoor het gevar dat de notie mensenrecht als morele ken van het modene recht onherkenbaar wordt, zonder dat dar voldoende compenserende rechtsbescheming voor in de plaats komt? Ik denk van wel.

Om de herkenbartheid en werkbarheid wan de notie mensenrecht to bevorderen probeer ik ze in deze studie te vertalen in een richtsnoer dat bestaat uit drie beginselen van mensenrecht. In de loop van het betoog hoop ik aannemelijk te maken dat deze beginselen wij heid, troum en zorg zijn en geen andere.

\section{Overzicht van de opbouw van dit boek}

Na dit inleidend hoofdstuk komen in het tweede hoofdstuk enkele kwesties rond de keuze wan een theoretisch kader aan bod. Als deze besproken zijn lijkt een aan de theorie van Jurgen Habermas aanknopend gespreksmodel van recht en democratie een voor dit onderzoek geschikte keuze. Als theoretisch kader lijkt het preciks de ineme spanning tussen legaliteit en legitimiteit van rechtsvorming in de democratische rechtsstaat an het licht te kumen brengen, waar het in dit onderzoek om gaat. In hoofdstuk drie wordt vervolgens de vruchtbarheid voor dit onderzoek beproefd van Habermas discourstheorie van het recht en de democratische rechtsstaat. ${ }^{18}$ De aandacht gaal daarbij vooral uit naar Habermas' concept van private en publieke autonomie, dat nat hel mij voorkont precies in mijn onderzok past. Daarop aanshitend wordt de notie mensenrecht in hoofdstuk vier nader geanalyseerd en uitgewerkt in de drie bovengenoomdo beginselen.

In het weede deel probeer ik de potentiele praktische bruikbarheid wan her in het cerste deel ontwikkelde richsnoer amnemelijk te maken in het Nederlandse rechl. In de hoofdstukken vijf tot en met acht spits ik dit onderzoek toe op het intermationalal privaatrecht (hoofdstuk 5) en belangrike deelgebieden in privaatrecth (hoofdstuk 6), publiekrecht (hoofdstuk 7) en intemationaal publiekrecht (hoofdstuk 8).

In hoofdstuk 9 worden de resultaten van het onderzoek in het Nederlandse rech vergeleken. Vervolgens beoondeel ik. da capo al fine - aan de hand van hed door mij voorgestelde richtsnoer het rechtsgehalte van het tweede Geertruidenbergarrest. de witsprak van de 


\section{Hoofdstuk!}

Hoge Raad war deze studie mee begonnen is.

In een korte slotbeschouwing waag ik mij aan enkele speculaties over universaliteit van drie beginselen van mensenrecht als tichtsnoer voor ieder in een Europese en wereldorde in wording. De technische kwaliteit van recht mag dan het terrein van juridische specialiste zijn. Dat wil niet zeggen dat ook de morele kwaliteit van recht aan specialisten mag, moet of kan worden overgelaten. Algemene aarvaardbaarheid van openbare ordening in een rechtsorde in een kwestie die jeder als lid van die rechtsorde rechtstreeks aangaat. 


\section{OP ZOEK NAAR EEN THEORETISCH KADER}

\section{Een gespreksmodel van recht}

Kort gezegd is dit onderzoek een zoektocht naar een operationeel te maken kern van de rechtsidee in een democratische rechtsstat. De combinatie van het zoeken naar een inhoudelijke kern wan recht in een procedureel perspectief van democratie vraagt een theoretisch kader dat deze beide aspecten kan omvatten. Mijn voorkeur gaat uit naar een gespreksmodel van recht en democratie. Dat maakt het mogelijk, een theoretisch kader op te bouwen vanuit de realiteit van alledaagse levenservaring. Die realiteit betreft zowel ieders gesprekservaring op het microniveau van het leven van alledag als het matschappelijk macroniveau van een in de westerse traditie gewortelde democratische rechtsvorming. Het is echter nog maar de vraag of in een consequent opgevat gespreksmodel van democratie sprake kan zijn van een onvervangbare inhoudelijke kern van recht.

Moet in een radicaal opgevalte democratie niet iedere imhoud van recht in beginsel door rechtsgenoten zélf als veranderlijk "in gesprek" kunnen worden gebracht? Stel dat dit inderdaad zo is, maakt dit mijn onderzoek dan niet overbodig? De dissertatie van Barendrecht, Recht als model van rechtvaardigheid, lijkt de overbodigheid van het zoeken naar een inhoudelijk-morele kern van recht te bevestigen.' Barendrecht zoekt niet op een zeer algemeen niveau naar een kerninhoud van de rechtsidee. Integendeel, hij stelt voor om geldend Nederlands recht, wetgeving en rechtspraak, te beschouwen als model van rechtvaardigheid. Waar ik uitga van rechtvaardigheid als model van recht gaat Barendrecht omgekeerd uit van recht als model van rechtvaardigheid. Zet een van ons beiden hier de zaak op zijn kop? Of getuigt Barendrechts aanpak eenvoudig van meer realiteitszin dan de mijne? Is het zoeken naar een zeer algemeen model van rechtvaardigheid een titopie?

Na een beschrijwing (par. 2) en bespreking (par. 3) van Barendrechts theorie blijft mijn centrale onderzoeksvraag overeind. Maar de vraag of een gespreksmodel een passend theoretisch kader woor dit onderzoek kan bieden, is dan nog niel beantwoord. Een antwoord blijkt afhankelijk te zijn van de onderlinge verhouding tussen democratie en mensenrecht. Als het primaat bij mensenrecht ligt en democratie daaraan ondergeschikt is, dan is een gespreksmodel van recht in dit onderzoek niet consequent door te voeren. Als echter omgekeerd het primaat bij democratie ligt, dan is mijn onderzoek als geheel niet uitvoerbaar. Het rijmt immers niet de notie mensenrecht te beschouwen als inhoudelijk norele kern van legitieme rechtsvorming in de democratische rechtsstaat en die notie tegelijk op te vatten als ondergeschikt aan democratie. 


\section{Hoofdstuk 2}

Een onderzoek naar cen eventuele prioriteitswerhouding (par. 4) zal een inteme samenhang tussen de noties democratie, mensenrechten en rechtvaardigheid aan het licht brengen die de vraag naar het primaat irrelevant maakt. Nadat die samenhang ook in een theorieennhistorische schets getraceerd is (par. 5), is de weg viij om een gespreksmodel van recht als theoretisch kader verder te bespreken. Dat gebeurt in het volgende hoofdstuk. Laten we nu eerst het model van Barendrecht nader bekijken.

\section{Barendrecht: recht als model van rechtvaardigheid}

Barendrecht gaat crvan uit dat rechtvaardigheid het doel is van rech. Hij ontwikkelt echter geen algemene maatstaf voor rechtvaardigheid. Rechtvaardigheid beschouwt hij als cen hol en leeg en volledig waardevrij begrip, een werkbegrip dat staat voor "al datgene wat men met het recht wil bereiken." Daarmee wil hij aangeven dat het recht niet te verwezenlijken is zonder acht te slaan op de inhoud ervan. Hij vindt het echter niet nodig meteen ook te bepalen welke die inhoud moet zijn.

Barendrecht betoogt dat ook zonder rechtvaardigheid nader te omlijnen de constante spanning tussen recht en rechtvaardigheid geconstateerd kan worden. Volgens hem is men zich van de spanning tussen het stelsel van het geldende recht en de rechtvaardigheid allijd al bewust geweest. "Aristoteles signaleerde al dat rechtsregels hun gebreken kunnen heoben. De billijkheid als correctief op het wettenrecht is door hem uitgevonden." "In het kader van zeer algemene theorieën over rechtvaardigheid bespreekt Barendrecht naast Aristoteles ook Kant en Bentham. "Rechtvaardigheid zou volgens Aristoteles betekenen, dat ieder het zijne krijgt. Rechtvaardigheid zou volgens de categorische imperatief van Kant inhouden, dat men aldus moet handelen, dat men van zijn wrijheid zo gebruik maakt, dat zij kan samengaan mel de vrijheid van een ander, op een wijze als volgens een algemene regel bepaald. Rechtvaardigheid zou volgens Bentham meebrengen, dat de grootste hoeveetheid geluk voor alle mensen tezamen wordt bereikt." drecht is dit soort algemene theorieën nooit in werkelijkheid aanvaard ats de basis voor een rechtsstelsel. De kans dat dat ooit zal gebeuren acht hij uitermate gering "al kan men
het nooit helemaal uitsluiten."s

In zijn theorie beschouwt Barendrecht het geldende positief recht als model van rechtvaardigheid. Wetielijke regels en rechterlijke uitspraken worden opgevat als weergave van de stand van de in de loop van de tijd verworven kennis over rechivaardigheid op het desbetreffende deelgebied van het recht. Zijn vooronderstelling ten atnzion van het Nederlandse rechtsstelsel is dat daarin recht en rechtvaardigheid dicht bij elkaar liggen. Met zijn theorie keent Barendrecht zich in het bijzonder tegen het werken met vage nomen in het huidige Nederlandse civiele recht. In zijn visie werken vage normen, als sluiproutes nat

Barendrecht $1992, p .24$, verwijst mat Aristoteles' Nicomacheische Ethiek $V .10$ on verder naar Pau Seholten, Verzamelde Geschriften I, p. 239-241

Burentex 1992, p. 41

Baremdrecht $1992, p, 41$ 
rechtvaardigheid, belemmerend op het verwerven wan kennis over rechtvaardigheid. Sterker nog, ze kunnen deze kemnis wernietigen. Als altematief pleit hij voor een stelsel met scherpere mat flexibele normen, die zowel door de wetgever als door de rechter gesteld kumnen worden.

Het zoeken naar rechtsregels als theorieèn of modellen wan rechtvaardigheid vergelijkt Barendrecht met het zoeken naar wetenschappelijke theorieën die een juiste beschrijving van de werkelijkheid geven. Met het oog op het ontbreken van een maatstaf voor rechtvaardigheid betoogt hij dat het verschil met de wetenschappelijke theorieen gradueel is.

ook daar berust de aanvaarding van een theorie uiteindeijk altijd op een keuze." Barendrecht gaat uit van het standaardbeeld van wetenschappelijke activiteit. Aan Poppers kritisch-rationalisme ontleent hij het criterium van falsifieerbaarheid van wetenschappelijke theorieën, de eis wan de mogelijkheid tot weerlegging. Aan Lakatos ontleent hij het criterium van behoud van informatie bij het vervangen van een theorie door een betere. Geheel vage normen, zoals de norm van redelijkheid en billijkheid, voldoen niet aan het criterium van behoud van informatie en daardoor zijn ze niet te falsifieren. Met het oog op kennis over rechtvaardigheid zijn ze waardeloos.

Tegen het einde wan Barendrechts betoog dient zich alsnog een mogelijke invulling vain rechtvaardigheid aan, als democratische legitimatie van het recht ter sprake komt. Het resultaat van de rationele maatschappelijke discussie komt dan naar voren als een mogelijk criterium van rechtvaardigheid. "Neernt men het criterium van het resultaat van de mat" schappelijke discussie als maatstaf, dan kiest men echter voor cen bepaalde invulling van het begrip rechtvaardigheid, op welke keuze men kritiek kan hebben", aldus Barendrecht."

\section{Bespreking van Barendrechts theorie}

In het kader van een voortdurende kritische discussie over de inhoud van recht spitst Barendrecht zijn studie toe op vage normen, die hij beschouwt als "sluiproutes naar rechtvaardigheid". Dat betekent in zijn visie dat ze als dragers van kennis van rechtvaardigheid watardeloos zijn. Die visie kan ik niet delen. Mij lijkt dat nu juist vage normen, zoals bijvoorbeeld de goede trouw, rechtstreeks de morele kern van recht kunnen raken. Dragen zulke normen geen kennis van rechtvaardigheid? Daarover gaat de eerste vrag. De idee van een voortdurende kritische discussie over de inhoud van recht acht ik mét Barendrecht essentieel voor de kwaliteit van recht. Daarover gaat de fweede vraag. ${ }^{\text {to }}$

6 Barendrecht 1992, p. 39-40.

7 Barendrecht 1992, p. 25 \%. verwijst natar Popper: The logic of scicurific discowery, 1968 (1959): The open sociely and its enemer delen 1 en 2, $1980(1945)$; The poverty of hishoricism, 1986 (1957): Conjectures and refutations, 1989 (1963). Zie Barendrecht 1992, p. 61 w over Lakatos, mot. verwij.

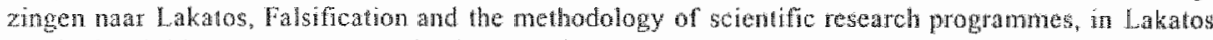
c.s. (red.), Criticism and the growth of knowledge, 1988 (1970); troors and rafutations, $1988(1976 \%$.

8 Barendrech 1992, p. 52

9 Barendreche 1992, p. 240.

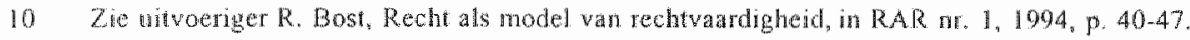




\section{Hoofdstuk 2}

Eerste vraug: Kan Barendrecht tegen de achtergrond van zeer algemene theorieẻn over rechtvaardigheid vage normen als goede trouw en redelijkheid en billijkheid afdoen als normen die geen dragers zijn van kennis van rechtvaardigheid? Voorop gesteld: juridischtechnisch gezien kan Barendrecht in zijn theorie vage normen zonder meer afdoen als waardeloos op het gebied van kennis van rechtvaardigheid. Sterker nog, hij kàn niet anders dain geheel vage nomen afdoen als informatief waardeloos. Dat eisen de criteria die hij zelf in zijn theorie aanlegt. Aan de hand van deze criteria, falsifieerbaarheid (Popper) en het behoud van informatie (Lakatos) zoals Barendrecht die opvat, valt een norm als redelijkheid en billijkheid eenvoudig door de mand.

De vraag is of een voorbeeld als dat van de billijkheid - waarvan Barendrecht zelf zegt dat Aristoteles deze "uitgevonden" heeft als correctie op gebreken van wettenrecht - alleen al sterk genoeg is om een kennisbegrip dat alleen scherpe normen als dragers van kennis herkent als te beperkt door de mand te laten vallen. Laten we eerst wat verder kijken naar Barendrechis woorbeelden van algemene theorieën.

Over de theorieën wan Aristoteles, Kant en Bentham spreekt Barendrecht als "vele prachtige natuurrechtelijke beginselen" die in de loop der eeuwen zijn ontwikkeld en die men kan beschouwen als zeer algemene theorieën over rechtvaardigheid. "Niet te ontkennen valt dan dat deze theorieën op zijn minst getuigen van een door de eeuwen heen zoeken naar algemene kennis van rechtvaardigheid. Aristoteles' beginsel "ieder het zijne" heeft als het ware het eeuwig leven. Onder privaatrechtelijk georiẻnteerde theoretici is het vanouds gemeengoed, ook al leidt het telkens weer tot kritische discussie over de invulling ervan. ${ }^{12}$ Hoe kan dat? Wijst dit niet op het door de eeuwen heen overdragen, kritisch toetsen en steeds verder ontwikkelen van kennis van rechtvaardigheid? Ook al voldoet het beginsel niet aan Barendrechts criteria van falsifieerbaarheid en behoud van informatie? Gaat voor het vrijheidsbeginsel zoals Kant dat heeft gehanteerd en getransformeerd tot morele kern van recht niet dezelfde redenering op?

Ook Barendrechts laatste voorbeeld van een zeer algemene theorie - Benthams criterium van het grootste geluk voor alle mensen samen - is hier interessant. Het betreft de transformatie van Benthams criterium in de maatschappijfilosofie van Popper. In zijn theorie over de inrichting van de samenlewing keert Popper de oude utilistische formulering van Bentham om. Hij gaat niet uit van het abstract wermeerderen van geluk maar van het concreet verminderen van ongeluk ${ }^{13}$ Ook dit voorbeeld illustreert fraai hoe het voortbouwen op zeer allgemene theorieën te maken heeft met het verwerven van kennis over rechtvaatdigheid. Vgl. J.H. Nieuwenhuis, leder het zijne, RM het zinne, Zwolle 1984, p. 1 16; Henk Simom, Publis 1988, p. 73 v.; Arent van Hatersolte, De mens en Vgl. MS. Groenhuijsen, De criticus bekritiseerd NJB 1982 privatrechr?, Zwolle 1993, p. 43. p. 31 gesignaleerde discussie over het belang van Popper voor de 161 v., in de door Barendrecht 1992, 
Interessant in het voorbeeld Bentham/Popper in vergelijking met de theorie van Barendrecht is, dat Popper zich niet als Barendrecht toelegt op kennis van rechtwaardigheid, maar op het oplossen van problemen van onrechtvaardigheid. In dat licht versehijnen rechters niet primair als constructeurs van scherpe normen maar als probleemoplossers die in steeds veranderende omstandigheden moeten oordelen. In dat licht moeten rechters in de algemene context van een zich steeds verder ontwikkelend leerproces en in de bijzondere context van een concreet probleem hun weg zoeken, in directe confrontatie en discussie met de partijen in het proces.

Is het aannemelijk dat in het geschetste leerproces het gebruik van zich in de loop der jaren steeds werder uitkristalliserende vage normen getuigt van het belemmeren of vernietigen wan kennis van rechtvaardigheid? Nee. Wie hier twijfelt raad ik aan de eerste casestudy die Barendrecht als test van zijn theorie over vage normen bespreekt, het afbreken van onderhandelingen, te vergelijken met de bespreking van de ontwikkeling wan dit leerstuk bij De Kluiver. ${ }^{1+4}$ Is het in de geschetste optiek van concrete probleemoplossing niet aannemelijk dat kennis van rechtvaardigheid óók opgeslagen ligt in zeer algemene normen als redelijkheid en billijkheid, in formules als ieder het zijne en in zeer algemene beginselen als het vrijheidsbeginsel? Zijn er verschillende soorten kennis? Ik denk van wel. De inhoudelijke opvatting van de redelijkheid en billijkheid, die in een compleet netwerk van algemene en specifieke bepalingen is vastgelegd in het huidige Nederlandse Burgerlijk Wetboek bevestigt deze gedachte. Barendrecht zelf noemt het BW het "beste voorbeeld" dat de wet de weergave vormt van regels "die door gestage groei van kennis op het gebied van rechtvaardigheid tot stand zijn gekomen, in een steeds voortdurend trial and error proces." ${ }^{.15}$ Al met al meen ik te kunnen concluderen dat de éénkennigheid ten aanzien van kennis van rechtvaardigheid in Barendrechts theorie onhoudbaar is. Daarmee is het gevaar geweken dat wage normen die de morele kern wan recht tot uitdrukking brengen waardeloos zijn op het gebied van kennis van rechtvaardigheid.

Tweede vraag: Hinki Barendrechts proefschrift op twee gedachten? Met verve verdedigt hij zijn theorie van recht als model van rechtvaardigheid. Tegen het einde van zijn betoog voorziet hij dit hol en leeg begrip rechtvaardigheid alsnog van een mogelijke inhoud. Dat brengt mij op de vraag: verdraagt Barendrechts theorie van recht als model van recht vaardigheid zich met zijn voorstel voor invulling van het begrip rechtvaardigheid? Voor een antwoord volg ik Barendrecht op het terrein van Habermas' communicatietheorie.

Mét Barendrecht vind ik een op Habermas' werk geinnspireerd ideaalbeeld van een rationele maatschappelijke discussie over normen van samenleving een aantrekkelijk uitgangspunt voor het bepalen van de inhoud van het recht. Het smalle kennisbegrip dat Barendrecht hanteert sluit echter niet aan op het brede rationaliteitsbegrip dat in het hart van Habermas' communicatietheorie zit. Barendrecht zegt dat Habermas getracht heeft "om

14 Barendrecht 1992, p. 82-92; H.J. de Kluiver, Onderhandelen en privatrecht, Deventer 1992, p. 245 v. Zie ook Bost 1994, p. 46 .

15 Barendrecht 1992, p. 238. Zie woor uitgebreide analyses wan de redelijkheid an billighetd in het oude net huidige BW: L.K. van Zaltbonme1, De betekenis wan het recht als systeen. Amsterdam 1993 , p. $45-62$. 


\section{Hoofdsuk 2}

zowel voor wetenschappelijke waarheidsaanspraken als voor normatieve oordelen eén rationaliteitsbegrip te formuleren." ${ }^{\text {:16 }}$ Dat klopt ook wel, zij het dat Habermas' rationaliteitsbegrip nog breder is. Het bevat niet alleen criteria voor waarheid in de objectieve wereld van feiten en voor juistheid in de sociale wereld van normen. Het biedt ook ruinte voor criteria voor watachtigheid in de subjectieve wereld van persoonlijke uitingen. ${ }^{\text {? }}$

Volgens Barendrecht biedt Habermas' Jeer de mogelijkheid om de imrichting van de maatschappij te doen bepalen op basis van kennis van de beste oplossing, maar ruimt ze ook een plaats in voor democratisch tot stand gekomen keuzes. En vervolgens zegt hij: "De kennis die is verworven, speelt immers een cruciale rol in de redelijke argumentatie."iø Ongetwijfeld gebruikt Barendrecht hier het kennisbegrip zoals hij dat eerder in zijn proefschrift ontwikkeld heeft. Dit begrip is echter exclusief gerichi op kennis die in $\mathbb{Z} 0$ scherp mogelijke juridische teksten is vast te leggen. Voor contextafhankelijke dialogische kennis die bij rechterlijke rechtsvorming komt boven drijven en die zich via vage normen en algemene rechtsbeginselen verder ontwikkelt is daarin geen plaats. Habermas' rationalileitsbegrip waagt echter een méérdimensionaal kennisbegrip, dat correspondeert met criteria voor waarheid, juistheid en waarachtigheid.

Het is van tweeẻn één: óf Barendrechts eng kennisbegrip, óf Habermas' ruim rationaliteitsbegrip. Een optie voor het laatste lijkt meer te beloven dan het vasthouden aan het eerste. ${ }^{19}$ In deze optiek zou Barendrechts theorie gezien kunnen worden als een poging om te komen "Beyond Objectivism and Relativism" karakter van rechtsvorming. Dat sluit aan bij een gespreksmodel als kritische discussie over de inhoud van recht. In het kader van dat model wordt het rationaliteitsbegrip in het volgende hoofdstuk nader besproken. Daarbij wordt ook bekeken in hoeverre een numere visie op kennis van rechtvaardigheid dan Barendrecht hanteert in combinatie met een invulling van rechtvaardigheid als resultaat van rationele maatschappelijke discussie aansluiten bij de procedurele en tegelijk inhoudelijke benadering van recht waar mijn
onderzoek wan uitgaat.

Hier kan geconcludeerd worden dat uit Barendrechts theorie niet blijkt dat realiter een procedurele benadering van recht niet te combineren valt met een inhoudelijke invulling van rechtvaardigheid. Maar voor mijn onderzoek zegt dat weinig. Het feit dat Barendrecht in zijn studie kiest voor een leeg rechtvaardigheidsbegrip maakt alleen duidelijk dat hij niet uitgaat van een inteme samenhang tussen democratie en een bepaalde inhoud wan de

18 Barmelicht 1992, p. 237.

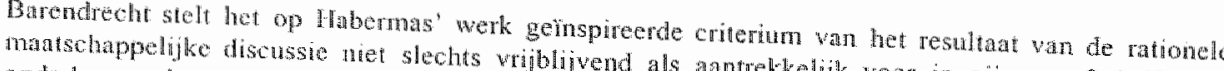

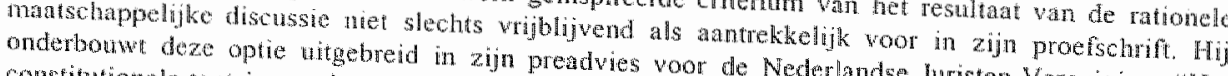

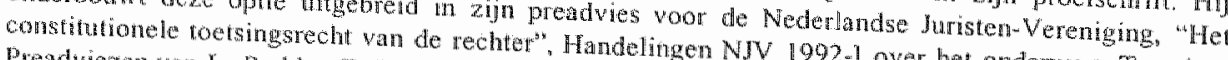

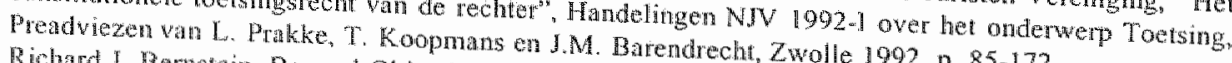
Richard $J$. Bertate in. Beyond Objectivism and R. Barendrecht, Zwolle 1992, p. 85-172.

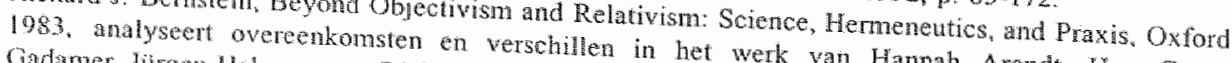

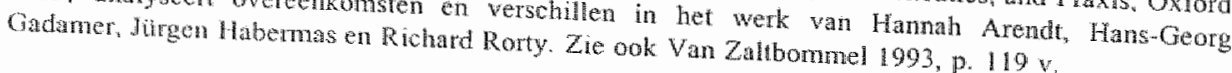


rechtsidee. Mijn onderzoek gaat daar wel van uit. Het veronderstelt een zodanige inteme samenhang tussen de notie mensenrecht en democratie, dat de vraag naar het primaat van een van beide irrelevant is. Is deze vooronderstelling houdbaar?

\section{De yraag naar het primaat: mensenrecht of democratie?"}

Het rechtsgehalte van openbare ordening hangt af van de kwaliteit van openbaarheid. ${ }^{21}$ In een gespreksmodel van recht correspondeert openbaarheld met openheid van publieke discussie. Deze openheid ziet niet alleen op vrijheid van meningsuiting en argumentatie in het publieke debat. Ze heeft ook te maken met de toegang tot het publieke debat, met het openhouden van formele gesprekskanalen en met tolerantie ten aanzien van informele kanalen. Dat laatste geldt óók als het informele publieke gesprek vanuit formele kanalen gelijk staat aan burgerlijke ongehoorzaamheid. ${ }^{22}$ Tenslotte geldt openheid ook voor de manier waarop de resultaten van publieke discussie worden geëffectueerd. Zo ruim opgevat typeert het begrip openbaarheid een consequent aan open discussie georiënteerd democratisch perspectief.

Op het begrip openbaarheid kom ik verderop in het betoog uitgebreid terug. Hier gaat het om de associatie van openbaarheid met de openheid van gesprek. De veronderstelling dat de openheid van gesprek cen principiêle erkenning van menselijke waardigheid inhoudt wordt vanuit een filosofische invalshoek in verrassend directe termen bevestigd. Ik denk aan de manier waarop Levinas de ervaring beschrijft van een wób het feitelijk gesprek liggende communicatieve relatie tussen mensen. Levinas typeert deze relatie, die alleen te kennen is door ze feitelijk te beleven, als gesprek "van aangezicht tot aangezicht". ${ }^{23}$ Het feitelijk gesprek vindt in deze opvatting zijn oorsprong niet in woorden of andere middelen van communicatie. Het vindt zijn oorsprong in een onmiddellijke relatie "van aangezicht tot aangezicht". Deze communicatieve relatie is niet mogelijk zonder principiële erkenning van menselijke waardigheid.

De hier bedoelde communicatieve relatie kan ook getypeerd worden als intersubjectiviteit. In cen antropologische betekenis is daarmee alles bedoeld wat zich in een vrije weder relatie tussen mensen afspeelt. ${ }^{24}$ In tegenstelling tot een producerend type van handelen, waarin een subject in een eenzijdige relatie tegenover een te bewerken object staat, wordt intersubjectief handelen gekenmerkt door een wederkerige relatie lussen subjecten onderling. Op het niveau van gesprek komt deze relatie tot uitdrukking in het met ellkar spreken en naar elkaar luisteren. Verbreed tot het hele gebied van het intersubjectief

$21 \mathrm{Vgl}$. Bost $1986, \mathrm{p} .17 \times 18$.

22 G $A$ den Hartogh, Burgerschap en ongehoorzamheid, RM Themis 1989, p. 5-33.

23 Enmanuel Lewinat, Van aangezich tot aangezicht, 1987; Hef menselijk gelaat, Essays wan Enmanual Levinas, gekozen en ingeleid door Ad Peperzak, Bilthoven 1969; De totaliteit en het oneindige, Iissay over de exterioriteit, wertald door Theo de Boer en Chris Bremmers, met antekening wan Theo de Boer, Bam 1961. Zie ook Theo de Boer, Tussen nilosofic en profetie, de wijsbegeerte wan Emmanuel Levinas, wede herziene druk. Baam 1988.

$24 \mathrm{Vgl}$. Th. van Velthoven, De intersubjectwiteit wan het zinn, Ka mpen 1988, p. 207 v. 


\section{Hoofdstuk 2}

handelen gaat het om geven en ontvangen. Let wel, het gaat niet om geven en nemen, maar on het over en weer geven en ontwangen. Intersubjectiviteit verdraagt zich niet met beheersing van de ander. Ze is aangewezen op thet wrij handelen door de ander. Daardoor is de intersubjectieve relatie er onvermijdelijk een van onderlinge afhankelijkheid. Die onderlinge afhankelijkheid houdt echter tegelijk een onherleidbare individuele onafhankelijkheid in stand. Kortom: het erkennen van de ander als ander houdt de erkenning in van individuele menselijke vrijheid en waardigheid.

Op het empirisch niveau van het alledaagse gesprek zelf ligt een principiële erkenning van menselijke vrijheid en waardigheid besloten in de vooronderstellingen waarvan ieder altijd al uit moet gaan om een concreet op onderlinge verstandhouding gericht gesprek te kunnen voeren. Die vooronderstellingen zijn: afwezigheid van dwang, toegankelijkheid voor kritiek en opreclatheid. Wil er sprake zijn van een gesprek in een gewone alledaagse betekenis van onderlinge verstandhouding, dan moet aan deze voorwaarden zijn voldaan. Zo'n gesprek is niet mogelijk als gesprekpartners van elkaar weten dat ze dreigen, zich immuun maken voor tegenspraak of liegen. ${ }^{25}$

De principięle erkenning van individuele menselijke vrijheid en waardigheid is de morele kern van de notie mensenrecht en tegelijk de kern van een op het open gesprek gebaseerde opvatting van democratie. Dat is de grondgedachte van dit onderzoek. Die gedachte maakt de vraag naar het primaat van mensenrecht of democratie irrelevant.

\section{Ideënhistorische voedïngsbodem voor interne samenhang tussen mensenrecht}

Om te bezien of voor de opvatting van een interne samenhang tussen mensenrecht en democratie in politieke theorieën een historische voedingsbodem te vinden is, passeren hierna enkele in de politieke filosofie algemeen bekende denkers kort de revue, als voorlopers in de westerse ontwikkeling van mensenrecht en democratie.

De voedingsbodem voor de theorie van de politieke denker Thomas Hobbes (1588-1679) is hat revolutionaire zeventiende eeuwse Engeland, in de overgang van een feodale naar een kapitalistische samenleving. ${ }^{25}$ Hobbes ziet geen heil in democratie. In zijn hoofdwerk, de Leviathan ${ }^{27}$ ontwikkelt hij een bevelstheorie. ${ }^{28}$ Daarin zijn de wetten van de Lewiathan, in die tijd moderne mechanistische centrale politieke macht heeft, geldend recht. In zijn dan beweging. De mens heef ergste dat een mens kan overkom ingebouwde drijfveer "to keep going". Doodgaan is het

Vgl. Wouter Wemer, De fundering wan het juridisch discours, Recht en Kritiek 1992, p. 52-72
Zie over deze achtergrond Grage

Zie over deze achtergrond Graham Lock, Van Hobbes tot Hegel: 1640-1820, in: Van Gunsteren/Lock, posities in de politieke filosofie, Leiden/Antw p. 56 v. Zie ook Lock/Van Gunsteren/Balibar, Sterke "Thomas Hobbes, Leviahosofie, Leiden/Antwerpen 1989, p. 43m57.

Zie over dit type theorie G.M. van Asperen, De goede Macpherson, Penguin English Library, 1982. 
vreemdbaar natuurrecht op zelfbehoud, dat onder alle omstandigheden overeind blijft. De fundamentele naturwet is volgens Hobbes "that every man, ought to endeavour Peace, as far as he has hope of obtaining it; and when he cannot obtain it, than he may seek, and use, all helps, and advantages of Warre."29

Het model van het sociaal contract waarin Hobbes zijn theorie giet, drukt de fundamentele notie uit dat het gezag van een owerheid niet van God en evenmin van de natuur afkomstig is. Het is mensenwerk. Het is de vrije mens zélf die de politieke macht als bevoegd gezag creëert. Als dat eenmaal is gebeurd eist Hobbes' politieke theorie gehoorzaarnheid van mensen aan de soevereine macht. Het is echter geen blinde gehoorzaamleid. Hobbes koppelt de gehoorzaamheidsplicht niet aan de macht van de soeverein zonder meer, maar aan de macht "by which he is able to protect them." Hobbes onderkent de te verwachten weerstand tegen de in zijn model ingebouwde absolute macht wan de Soeverein. Met burgeroorlog als ergste schrikbeeld voor ogen is hij echter kort en krachtig: "Soveraigne Power is not so hurtfull as the want of it."3i

Hobbes wordt wel eens voorgesteld als pleitbezorger van een onbeperkt absolutisme. ${ }^{32}$ In zijn theorie kan de soeverein zijn bevelen echter niet geven dan in de taal van her recht. ${ }^{3.3}$ Intern garandeert dat een rechtsorde die de onderdanen subjectieve vrijheden volgens algemene wetten garandeert. Het legitimiteitsprobleem komt in de theorie van Hobbes echter miet binnen de rechtsorde aan bod. Bij de constructie van de theorie lost dat zich in eén klap op.

Gelet op het bevelskarakter van zijn theorie is bij Hobbes geen sprake van een interne samenhang tussen noties van mensenrecht en democratie. In het verlengde van zijn sociaal contractstheorie kunnen leden van een rechtsgemeenschap niet méér dan een stilzwijgend appèl doen op politieke machthebbers, tot erkenning van menselijke vrijheid en waardig. heid. Maar door de kennelijke macht van de Leviathan en de kennelijke kwetsbaarheid van zijn onderdanen is dat wél een voortdurend dringend appèl. Het is immers duidelijk dat de macht van de Leviathan in deze theorie gebaseerd is op respect woor het onvervreemdbaar natuurlijk recht op zelfbehoud van de onderdanen. Zo gezien zijn in Hobbes" theorie wél een principieel respect voor menselijke vrijheid (tot zelfbehoud) en openbare ordening als rechisordening intern met elkaar verbonden. Wat zijn sterke voorkeur voor een monarchie boven een aristocratie of een democratie betreft geeft Hobbes toe dat deze voorkeur voor de monarchie als "the most commodious government" door hem niet overtuigend beargumenteerd wordt "but only probably stated." 3 "34

30 Hobbes 19821651, p. 272.

31 Hobbes $1982 / 1651$, p. 238.

32 Vgl. C.W. Van der Pot-Donner/Prakke, Handboek wan het Nederlandse Staatsrecht, dertiende druk, Zwolle 1995, p. 17.

33 Zie hierover Jürgen Habermas, Faktizitat und Geltung, Zweite Auflage, Frankfurt am Man 1992, p. I.18, Thomas Habbes, The Citizen, p. 104. 


\section{Hoofdstuk 2}

In vergelijking met de bevelstheorie van Hobbes komt in de beritstheorie ${ }^{35}$ van Locke (1632-1704) een omslag tot uitdrukking. Natuurrecht heeft miet meer de functie van het creëren van plichten van onderdanen en regeermacht van de overheid, zoals nog bij Hobbes. Natuurrecht krijgt de functie van rechten van de burger en plichten van de overheid. Behalve "life and liberty" regelt de natuurwet in de vorm van de rede ook eigendommen, in het verlengde van de mens als bezitter van zijn eigen persoon en arbeidskracht ${ }^{36}$ Locke ageert niet alleen tegen een traditioneel "goddelijk" of "natuurlijk" recht van vorsten op regeermacht. Met zijn model van het sociaal contract pleit hij expliciet voor vrijheid van de burger en een daarmee corresponderende waakplicht van de overheid.

Anders dan Hobbes past Locke zijn natuurrechtstheorie sterk aan de belangen van de bezittende klasse in het opkomend kapitalistisch systeem aan. Waar Hobbes zijn gelijkheidsbeginsel consequent doortrekt, accepteert Locke klasse-ongelijkheid. Sterker nog, in de manier waarop hij zijn eigendomstheorie virwerkt krijgt klasse-ongelijkheid een extra accent. Economische vrijheden zijn expliciet en ruim bedeeld maar duidelijk niet weggelegd woor ieder. Slechts "freemen" zijn in de theorie van Locke partij bij het sociaal contract. Door positieve ansluiting zijn zij volwaardig lid wan de politieke gemeenschap en kunnen zij hun belangen veilig stellen. De massa loonwerkers en werklozen acht Locke niet in staat toit het rationeel gedrag dat voor aansluiting bij het sociaal contract is vereist. De massa wordt geacht stilzwijgend in te stemmen omdat ze door het leven in de gemeenschap profijt trekt van het sociaal contract. ${ }^{37}$

In tegenstelling tot Hobbes geldt Locke tot de dag van vandaag als voortrekker van de klassieke grond- en mensenrechten. Aan de oppervlakte komt in zijn werk inderdaad de idee van mensenrecht naar voren die bij Hobbes verborgen blijft.

Bij nader toezien is echter eerder de theorie van Hobbes dan die wan Locke gebaseerd op een principiêle erkenning van menselijke vrijheid en waardigheid als kern van de notie mensenrecht. In de theorie wan Hobbes worden alle onderdanen consequent rechtens gelijk behandeld: niemand heeft recht van spreken. Bij Locke zijn vrije mannen als leden van de bezittende klasse "in gesprek" met politieke machthebbers, terwijl de bezitloze massa geen
recht van spreken heeft.

Ideeën over directe democratie vinden we bij Rousseau (1712-1778). Mét Locke stelt Rousseau de vrag naar de voorwaarden waronder overheidsgezag legitiem kan zijn. In zijn antwoorden liggen echter nieuwe accenten: die van consensus en wederzijdse verplichtingen van alle betrokkenen. ${ }^{38}$ In de visie van Rousseau komt door een bundeling

Van Asperen 1978, p. $78 \mathrm{w}$

John Locke. Two Treatises of Giovemment (1690) 1965

Locke brengt werkloosheid en anmoede niet in verband met economisehe owrzaken. Hij ziet ze als verdubbeling van de werkloosheid veroorzaakt worde voor Handel schrijft Locke in 1697 dat disclpline and corruption of manners" C. B Mordt door "mothing alse but the relaxation of Indiwidualism, ninth impression, Oxford/New YorkThorson. The political Theory of Possessive Jean-Jacques Ronssean, Du Contrat Social (1762). 
van krachten die nodig is om te overleven de kracht wan de hele gemeenschap ten dienste wan ieder lid van die gemeenschap te staan. Andere modellen van het sociaal contract gaan ervan uit dat bij het aangaan van het contract ieder tof op zekere hoogte wrijheid inlevert om belangrijker winst aan bescherming te kunnen genieten. Rousseau lijkt niets aan individuele vrijheid te willen opgewen en toch voor ieder winst te willen boeken. Verlies van natuurlijke menselijke vrijheid wil hij compenseren door burgerlijke vrijheid. De consequenties wan fysieke ongelijkheid wil hij beperken door de ontwikkeling wan morele of politieke gelijkheid. ${ }^{35}$ Maar Rousseau is reëel genoeg om in te zien dat onder slechte regeringen politieke of morele gelijkheid een illusie is die slechts de ellende van de armen en de uitbuiting door de rijken in stand houdt ${ }^{40}$

Strikt genomen verstrikt Rousseau zich met zijn model van het sociaal contract in een aantal tegenstrijdigheden." Sommige van zijn ideeën lijken niet to passen in het keurslijf van het sociaal contract. Voor ons is echter niet zozeer zijn constructie van het sociaal contract interessant, als wel Rousseaus ideeën over op gelijkwaardigheid van ieder te baseren besluitvorming in een sociale orde. Bij het sluiten van het sociaal contract krijgt ieder recht op medezeggenschap en medebeslissingsrecht. In deze beide niet overdraagbare rechten ziet Rousseau de garantie van een ideale samenlevingsvorm. De besluitvorming van de gemeenschap in de vorm van wetgeving drukt zich uit door middel van de algemene wil, "la volonté générale", niet te verwarren met de wil van allen, "la volonté des tous". De wil van allen is kort gezegd de optelsom van wat ieder individu wil, zuiver afgaande op de eigen wensen en verlangens. Het is een aggregaat van de wil van ieder afzonderlijk. Wil er daarentegen sprake zijn van de algemene wil, dan moet an een aantal voorwaarden zijn voldaan.

Om te beginnen moeten mensen in hun besluitvorming niet uitsluitend uitgaan van eigen voordeel maar van het voordeel van allen. Verder moeten ze over voldoende informatie beschikken en het behartigen van groepsbelangen in plaats van het algemeen belang moet vermeden worden. Als de behartiging van groepsbelangen niet te voorkomen is, dan moeten er veel sub-groepen zijn. Geen groep mag sterker zijn dan een van de anderen.

Tenslotte mag de algemene wil uitsluitend uitgesproken worden op terreinen die voor ieder gelijk van toepassing zijn. Beslissingen moeten ieder dezelfde rechten toekennen en ieder dezelfde plichten opleggen.

Bij Rousseau stat het uitoefenen wan politieke rechten niet meer als bij eerdere politicke denkers onder het voorbehoud van natuurlijke rechten. Zo te zien verwerpt Rousseau de notie van mensenrecht, ondat ze niet te verenigen is met het primaat van do volonte générale. Maar het normatief gehalte van de notie mensenrecht komt tot uitdrukking in de uitoefening van het democratisch wetgevingsproces. In dit proces komt de verenigde soevereine wil van de staatsburgers (de idee van volkssoevereiniteit) tot uitdrukking in

41 Vgl. Van der Pot-Donner/Prakke 1995, p. 29 v; Van Gunsteren/Lock 1977, p. 110 w: Lock/Van Gunsteren/Balibar 1989 , p. 106 v.; Van Asperen 1978, p. 82 \%. 


\section{Hoofdstuk 2}

algemene en abstracte wetten. Deze wetten laten uitsluitend regelingen toe die gelijke subjectieve vrijheden voor ieder lid van een rechtsgemeenschap waarborgen. Een correcte procedurele uitoefening van het democratisch besluitwormingsproces garandeert bij Rousseau tegelijk een correcte materiële invulling van een oorspronkelijk mensenrecht op gelijke subjectieve handelingsvrijheid. In Rousseaus volonté génerale is van huis wit het recht op gelijke subjectieve vrijheden in de private én publieke sfeer ingebouwd.

Bij Rousseau lijkt het inzicht door te breken van een interne samenhang tussen de noties mensenrecht en democratie. Mar in zijn werk valt ook iets van een onuitgesproken concurrentie tussen die beide noties te bespeuren. Een mogelijke verklaring is, dat in die tijd de traditionele eenheid van zedelijkheid, politiek en recht zodanig onder druk is komen te staan, dat een onderscheid is ontstaan tussen noties van ethische zelfontplooiing en morele zelfbepaling. ${ }^{4 z}$

Ethische zelfontplooiing oriënteert zich aan het eigen goede leven of aan dat van de eigen groep. Morele zelfbepaling oriënteert zich aan universele rechtvaardigheid. Tussen ethische zelfontplooiing en volkssoevereiniteit aan de ene kant en morele zelfbepaling en mensenrecht aan de andere kant bestaan affiniteiten waarop in bepaalde politieke tradities meer of minder sterk de nadruk is gelegd. Grof gezegd staat in een "republikeinse" traditie volkssoevereiniteit voorop, als uitdrukking van ethische zelfontplooiing. In een "liberale" traditie staat mensenrecht voorop, als uitdrukking van morele zelfbepaling. Zo gezien staan in deze tradities mensenrecht en democratie inderdaad eerder in een concurrentieverhouding dan dat ze elkaar veronderstellen.

Door staatsburgerlijke autonomie op te vatten als het verwerkelijken van een bewust gekozen levensvorm van een concreet volk geeft Rousseau de idee van zelfbepaling cerder een ethische dan een morele betekenis. Zijn tijdgenoot Kant (1720-1804) vat autonomie eerder op als morele zelfbepaling. ${ }^{43}$ In tegenstelling tot Rousseau laat Kant "natuurlijke rechten" die de private autonomie van mensen beschermen aan de wil van de wetgever voorafgaan. ${ }^{44}$ Waar Kant het primaat van mensenrecht bezegelt, versmelten bij Rousseau de noties van mensenrecht en democratie in de volonté générale.

\section{Publieke autonomie en de morele kern van het recht}

De al in het werk van Rousseau en Kant vermoede interne samenhang tussen mensenrecht en democratie komt tot uitdrukking in het normatief gehalte van de uitoefening van publieke autonomie. In deze - bij Habermas ${ }^{45}$ aan te treffen - eigentijdse opvatting van

Voor en korte schets van de leer van mmanuel Kant, zie Arie Leijen, Profielen wan ethiek. wan Herover nithebreing, Muiderberg 1992 , p. 87-121.

Zie voor een konte typering wa 1992, p 132 w. Zie ook Van der Pot-Donnevprake 1995, p. 33-34 nuteit Roos 1990, p. 33. 
overgeleverde ideeën wordt publieke autonomie niet al gegarandeerd door de vorm van algemene wetten maar pas door communicatieve menings- en wilsworning wardoor deze wetten tot stand komen. Deze opwatting van Habernas, warop in het volgende hoofdstuk nader zal worden ingegaan, biedt niet alleen een geschikte afronding van de korte ideeenhistorische verkenming van een interne samenhang tussen de noties mensenrecht en democratie. Het begrip publieke autonomie is ook een geschikt uitgangspunt voor hei verder bekijken van een gespreksmodel van recht waarin zowel procedureel als inhoudelijk de morele kern van recht tot uitdrukking kan komen. 



\section{RECHT "SPREKEN"}

\section{Inlleiding}

In de aan het einde van het vorige hoofdstuk naar voren gekomen opvatting van publieke autonomic gaat Habermas uit van gelijkoorspronkelijkheid van private en publieke autonomie. In termen van een gespreksmodel wijst dit op een met gelijk gewicht rechtens beschermen van de beslotenheid in de private sfeer en de openbaarheid van het gesprek in de publieke sfeer. Dit concept wordt in dit hoofdstuk beschreven in het kader van Habermas" reconstructie van een stelsel van subjectieve rechten in de democratische rechtsstaat (par. 2). Bij het bekijken van het concept van private en publieke autonomie dringt zich de vraag op of het niet een weliswaar fraaie, matar in de praktijk niet waar te maken theorie is (par. 3). De vraag is met name ook hoe het concept van private en publieke autonomie te rijmen valt met de realiteit van politieke macht (par. 4). Daarbij komt een differentiatie van politieke macht in communicatieve en administratieve politieke macht in beeld. In aansluiting daarop komt het openbaarheidsbegrip aan bod (par. 5). Ondat dit onderzoek gaat over rechtvaardigheid en rechtsworming in de rechtspraak, komt vervolgens de relatie tussen gespreksmodel, openbaarheid en rechtspraak aan de orde (par. 6). Meer in het bijzonder zal daarbij nog aandacht worden geschonken aan de diverse dimensies van rationaliteit die (ook) in de rechtspraak een rol spelen (par. 7). Bepleit wordt de systeemen leefwereld in het recht te koppelen door verruiming wan het rationaliteitsbegrip (par. 8).

\section{Private en publieke autonomie...}

Uitgangspunt in thet concept van private en publieke autonomie is de notie van subjectieve rechten die corresponderen met gelijke subjectieve handelingsvrijheid.' Tn thet moderne recht bakenen subjectieve rechten de ruimte af warbinnen een rechtssubject tot handelingsvrijheid gerechtigd is. Algemene en abstracle wetten leggen in deze opvatting de grenzen van jeders gelijke vrijheid vast. In dit wetsbegrip komt de voor het recht karakteristieke idee van onpartijdigheid tot uitdrukking. Bij uitstek kont de notie van gelijke subjeclieve vrijheidsrechten tot uitdrukking in de idee van de universele rechten van de mens.

Op basis van de idee van gelijke subjectieve handelingswrijheid reconstrueert Habermas stap woor stap een stelsel wan subjectieve rechten dat de private en publieke autonomic als problematische samenhang wan subjectief recht en publiek recht werklart Habemas mede uit een erfgoed wan het natturrecht: de idee dat positief recht ondergeschikt zou zijn an matuturlijk of moreel recht. 
zelfwetgeving van burgers als leden van een democratische rechtsorde met gelijk gewicht tot gelding moet brengen. ${ }^{2}$ Hier geef ik een korte beschrijving van deze reconstructie, als toelichting bij het concept van private en publieke autonomie. Verderop in het betoog kan deze reconstructie tevens dienst kan doen als een soort proef op de som. Onderzocht kan worden in hoeverte mijn op de morele kern van recht gebaseerd richtsnoer aansluit bij Habermas' schets van een stelsel van subjectieve rechten.

Met lhet oog op verschillende typen handelingsnormen drukt Habermas het autonomiebegrip zelf uit in een algemeen discours-principe. Dat algemeen principe omvat zowel rechtsnormen als morele normen. Het luidt als volgt. "Gültig sind genau die Handlungsnormen, denen alle möglicherweise Betroffenen als Teilnehmer an rationalen Diskursen zustimmem könnten." A.ls het in de vorm van recht tot uitdrukking komt, dan neemt het discoursprincipe de vorm van een democratie-principe aan. ${ }^{4}$ Op basis van dit democratie-principe kunnen precies die subjectieve rechten van ieder gereconstrueerd worden, die mensen onderling moeten erkennen als een logische voorwaarde on hun samenleven door middel van positief recht legitiem te kunnen regelen.

Een eerste categorie rechten in Habermas' reconstructie betreft het politiek autonoom vorm geven aan de idee van gelijke subjectieve handelingsvrijheden. Een tweede categorie betreft het politiek autonoom vorm geven aan de status van medelid in een vrijwillige associatie van rechtsgenoten. Een derde categorie betreft rechten die voortvloeien uit het politiek autonoom vorm geven aan individuele rechtsbescheming. In deze reconstructie mogen deze categorieën rechten nog niet begrepen worden als afweerrechten tegenover overheden, zoals de klassieke liberale rechten van de mens. In deze fase van dit denkmode! gaat het om het basale niveau van het regelen van de betrekkingen tussen vrije burgers onderling. Van een overheid en statsdwang is dan nog geen sprake. De genoemde categorieën rechten zijn voorwaarden voor sociale integratie onder gelijken door middel van recht. Ze betreffen private autonomie van rechtsgenoten, voor zover deze elkaar in hun rol als adressaten van wetten erkennen.

De idee autonomic eist dat degenen die als adressaten aan het recht onderworpen zijn, zich tegelijk als auteurs van het recht kunnen opvatten. Dat correspondeert met publieke autonomie. De idee van zelfwetgeving moet in het recht zélf tot gelding worden gebracht. In een volgende stap in deze reconstructie krijgen de rechtssubjecten naast de rol van adressaten dan ook de rol van auteurs van hun rechtsorde. Een daarmee corresponderende vierde categorie rechten heeft betrekking op gelijke kansen voor ieder tot deelname aan processen van menings- en wilsworming waarin burgers hun politieke autonomie uitoefenen en legitiem recht tot stand brengen. In een volgende denkronde wordt deze categorie politieke rechten reflexief toegepast op de feitelijke interpretatie van, en de politieke en juridische vormgeving aan de onder een tot en met vier genoemde categorieën rechten. Zo maakt hun politieke status wan vrije en gelijke staatsburgers het de rechtsgenoten mogehijk hun private en publieke antonomie zélf te interpreteren en praktisch vorm te geven.

2 Hinermas 1992, p. $151 \%$

3. Habermas 1992, p. 138 . Op de diverse conponenten van dit discours-principe ga ik in het volgende lioofdstuk nader in

4 Habernas 1902, p. $151 \mathrm{v}$ 
Met het oog op het praktisch vorm geven aan private en publieke autonomie impliceren de vier genoemde categorieën rechten tenslotte een vijfde categorie rechten. Deze betreft het in sociaal, technisch en ecologisch opzicht waarborgen van levenswoorwaarden voor zover dat nodig is on ieder gelijke kansen te geven om daadwerkelijk gebruik te maken van de eerste vier categorieën rechten.

Het stelsel van rechten moet uitgewerkt en vastgelegd worden in concrete rechtsregels, in een concrete rechtsorde. Dat wil niet zeggen dat dit stelsel van theoretisch ingevoerde rechten als natuurrecht of ander "hoger" recht aan concrete wettelijke of verdragsrechtelijke interpretaties voorafgaat. Het is eerder ongekeerd. Een bepaalde grondwettelijke of mensenrechtelijke pasitivering van rechten leidt juist tot het besef dat deze rechten voorwaarden zijn die het mogelijk maken het samenleven door recht legitiem te regelen. Het gaat bij het geschetste stelsel van rechten immers ook om een reconstructie van voorwaarden voor legitiem recht. In deze visie moeten ook de meest basale rechten van de mens via het democratisch proces zelf als rechtsregels vastgelegd worden.

Historische ontwikkelingen op het gebied van rechten van de mens zijn in Habermas" reconstructie te begrijpen als telkens contextafhankelijke interpretaties van hetzelfde stelsel van rechten. Klassieke rechten van de mens zijn te begrijpen als interpretaties van de eerste vier categorieën rechten als waarborgen van gelijke subjectieve private handelingsvrijheden, de algemene status van medelid in een vrijwillige associatie van rechtsgenoten, rechtsbescherming en politieke vrijheden. Sociale rechten van de mens zijn te beschouwen als uitwerkingen van de vijfde categorie rechten. Een democratisch perspectief van communicatieve vrijheid komt aan bod in de politieke vrijheden die dóorwerken in het politiek autonoom vorm geven aan het gehele stelsel van rechten.

De gedachte aan rechten als voorwaarden on op het macroniveau van een samenleving het democratisch rechtsvormingsproces mogelijk te maken doet denken aan de eerder besproken yoorwarden die op het microniveau van persoonlijke beirekkingen thet alledargse gesprek mogelijk maken. Dat is niet verwonderlijk. Het hier bedoelde stelsel van rechten ligt precies in het verlengde van de eerder besproken vooronderstellingen die het gesprek mogelijk maken. Het houdt precies die rechten in, die de alstand overbruggen tussen het interpersoonlijk niveau wan gesprek en het gemeenschappelijk niveau van democratische menings- en besluitvorming in een rechtsgemeenschap van gelijkwaardige, mondige rechisgenoten die hun samenleven door middel van recht legitiem willen regelen.

\section{3. ...een niet operationeel te maken concept?}

In een gespreksmodel komt private autonomie overeen met de vrijheid om zich aan het gesprek in de openbare politiek-juridische sfeer te onttrekken. De private autonomie van mensen als rechtssubjecten reikt precies zover als ze niet publickelijk ter verantwoording geroepen kunnen worden, rechtens gén gronden hoeven aan te geven voor het eigen doen en laten. Waar de grens van deze private autonomie in bepaalde soorten gevallen en situatie-types ligt, moet uitgemaakt worden bij rechtsvorming als het uitoefenen van publieke autonomie. Cruciaal voor het waarborgen van ieders morele autonomie is in dit concept 


\section{Hoofdstuk 3}

Jet evenuthch in de interne verhouding tussen private en publieke autonomie. Het een gat niet ten koste van het ander. Het een is niet te hebben en te houden zonder het ander.

In cen opvatting warin private en publieke autonomie met gelijk gewicht gewaarborgd moeten worden, is de grens iussen het private on het publieke niet eens en voor al te trekken. De grens van publicke vrigheid ligt bij de individuele private vriheid van iedere rechisgenoot. Maar de grens zelf van deze private vripheid moet telkens opnieuw in de uitoefening wan publicke wriheid geconeretseerd worden aan de hand van gemeenschappelike opvattingen over maatschappelike problemen. De onmogelijkheid on eens en voor al cen scherpe scheiding te maken tussen het private en het publieke makt het onderscheid niet zinloos. Integendeel, het brengt precies de onvermijdelije spanning aan het licht tussen individuele en gemeenschappelijke aspecten van menselijke vrijheid in een sameneving.

Is het hier weergegeven onderscheid tussen private en publieke autonomie een fraaie constructic die het onmogelijke wil combineren? Wordt hier in theorie de realiteit geweld aangedaan van cen niet met jeders morele autonomie te verenigen boven de betrokkenen staande wetgever of superieure wet, die voorschrijf welke morele belangen wel en niet rechtens beschemenswaard zijn? rk denk dat zo"n met private en publieke autonomie niet te verenigen hogere wetgever of superieure wet alleen in een éndimensionaal individualistisch perspectief in beeld verschint. Daarin is inderdaad geen rumte voor een differentiatic in het autonomiebegrip. Dat wordt anders als we vamuit een individueel én een gemeenschappelijk perspectief, als twee kanter van éen medaille, naar rechtsnormen in een rechtsorde kijken. Rechtsgenoten kunnen zich dan aan de ene kant beschouwen als individucle adressaten wan rechtsmomen en aan de andere kant ók als gemeenschappelijke auteurs van dezelfde rechtsnomen. In 20 "n rechtsorde kunnen boven betrokkenen staande autoriteiten en superieure wetten ontmaskerd worden als onrechtmatig, juist omdát ze in strijd zijn met private en publieke autonomie van de rechtsgenoten. Dat is mogelijk vanuit het besef dat in een legitiene rechtsorde morele autonomie zowel in de private als in de publieke sfeer geliktijlig en met gelijk gewhich tot gelding moeten komen om de morele vrijherd van ieder als rechtsgenoot te kumnen waarborgen.

Ook al is het theoretisch denkbaar, een andere vraag is, of en hoe het concept van private en publieke automonic op cen integere manier operationeel te maken en te houden is. Heef bijvoorbed eon instifutionele scheiding tussen een priwate en een publike sfeer niet mede geleid tot het vasthouden aan een in theorie achterhalde man feitelijk nog steeds bestande onderschikking van wouwen? In historisch perspectief valt in de westerse traditie de dominantie van mamen, in de privésfeer als gezinshoofden en in de publieke sfeer door thet feitelijk uitsuiten van vrouwen uit het politieke leven, niet te bewisten. "Door het gevoelsmatige bij vrouwen en bij de opvoeding van kinderen in de private sfeer te

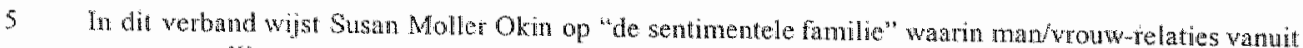
cen voorstelling van romantische lefe werden geduid. Zie Susan Moller Okin, Women and the

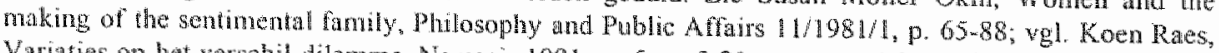
Varaties op het veschildtemma. Nemesis 1991 m. 5, p. $5-21$, een overzichtsatikel wan ontwikelin-

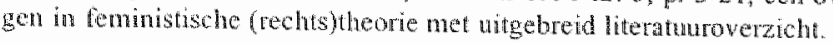


lokaliseren, kon de dominantie van mannen in de publieke sfeer en over het gezin verantwoord worden. Daardoor konden anti-patriarchale politieke theorieën over individuele vrijheid zoals de eerder besproken ideeën van Hobbes en Locke in de private sfeer onschadelijk worden gemaakt.

Het voorbeeld van man/vrouw-relaties toont atan dat door taaje vooroordelen de sfeer van politieke openbaarheid aan bepaalde categorieèn mensen onthouden kan worden. De private sfeer van intimiteit en zorg kan bijvoorbeeld toegedacht blijven aan vrouwen als het domein waar zil exclusief competent zijn. Zulke vooroordelen vragen om een grondige problematisering van de institutionele scheiding tussen het private en het publieke. Dat neemt niet weg dat met het oog op vrijheid voor ieder het onderscheid zélf tussen een private en een publieke sfeer ók - of misschien wel juist - in hedendaagse complexe samenlevingen niet weg te denken is. Raes wijst er op dat steeds verschuivingen plaats grijpen in de scheiding tussen het publieke en het private en dat geen a-historische bepalingen geformuleerd kunnen worden van wat tot de "openbare orde" gerekend wordt. ${ }^{6} \mathrm{lk}$ deel de opvatting van deze auteur dat het recht op het trekken van de grens tussen het private en het publieke fundamenteel gepolitiseerd kan (en wat mij betreft moet) worden, zonder het bestaan van die grens zélf te willen opheffen. In deze opvatting past naar $\mathrm{ik}$ meen het concept van het geiijktijdig en met gelijk gewicht tot gelding brengen van private en publieke autonomie.

\section{De samenhamg van private en publieke autonomie met politieke macht}

In het concept van private en publieke autonomie maken mensen die zich in een private sfeer terugtrekken en niet actief aan het politieke leven in de publieke sfeer deelnemen een keuze. Wie dat beweert moet begrijpen dat door allerlei externe omstandigheden het keuze-moment in de praktijk wer te zoeken kan zijn. De kloof tussen de beslotenheid in de private sfeer en de politieke openbaarheid in de publieke sfeer kan in onze tijd net zo onoverbrugbaar lijken als ze in de klassieke tijd in de Griekse polis voor vrouwen en slaven was. Maar er is een wezenlijk verschil. In de Grickse polisfilosofie was het ondenkbaar dat anderen dan vrije mannen als hoofden van private huishoudingen aan het politicke leven in de openbaarheid zouden kunnen deelnemen. In onze tijd dringt daarentegen praktisch wereldwijd het besef door dat er geen goede gronden te winden zijn waarom in beginsel niet ieder gelijkelijk toegang toekomt tot het openbare politieke leven binnen zijn of haar samenleving. Dat daaraan velerlei praktische belemmeringen in de weg kunnen staan doet aan dat inzicht zelf niet af. Integendeel, juist deze belemmeringen worden steeds meer als onrechtvaardige beperkingen van vrijheid onderwerp van kritische publieke discussie.

Als vrijheid voorop staat, dan is het actief deelnemen aan het politieke leven in de publieke sfeer niet af te dwingen. Maar dat wil niet zeggen dat niet ieder in een rechtsgemeenschap in beginsel bij het politieke leven betrokken is. Zelfs al zou ieder zich op het 
nivcau wan het toepassen van recht beperken tot eigen rechtsbescherming, dan nog zou dat in de hier bedoelde politiek-juridische betekenis een publieke aangelegenheid zijn. De bescherming van iets dat in een rechtsorde geacht wordt door ieder als recht te worden gerespecteerd, gaat in en dóor dat respect ieder lid van die rechtsorde aan. Dat geldt ook voor het niveau van het vormen van recht. Met respect voor het in een vrije samenleving niet afdwingbare van actieve deelname aan het politieke leven is ieder lid van een rechtsorde als rechtsgenoot potentieel drager van politieke macht.

Via communicatieve vrijheid zijn we zonder veel onhal terecht gekomen bil politieke macht. Om deze overgang van vrijheid naar macht te verhelderen is het nuttig het begrip politieke macht te differentiëren in communicatieve en administratieve macht. ${ }^{7}$ Communicatieve politieke macht sluit aan bij communicatieve wijheid die voor legitieme rechtsvorming getransformeerd moet worden in politieke macht. Administratieve politieke macht komt overeen met de uitvoerende macht van een via legitiem recht aan de communicaticve macht van rechtsgenoten gebonden staatsapparaat. Het grondfenomeen van macht is in deze visie niet de kans om bimnen een sociale relatie de eigen wil tegen weerstand in door te zetten, naar de bekende definitie van Max Weber. Het grondfenomeen van politieke macht is in deze opvatting het potentieel van een in vrije communicatie gevormde gemeenschappelijke wil.

Hannah Arendt wijst er naar ik meen treffend op dat niemand het type communicatieve macht kan "bezitten". Wijst dat er niet op dat communicatieve macht als het op daden aankont een illusie is? Blijft een model van vrije politieke communicatie niet steken in woorden? Dat hoeft niet, denk ik. Het publiek gebruik van communicatieve vrijheid maakt méér mogelijk dan een rationele gemeenschappelijke menings- en wilsvorming. Gedeeide overtuigingen hebben een motiverende kracht. Op zich zelf genomen is die niet sterker dan de motiverende kracht van goede gronden. Dat communicatieve vrijheid desalniettemin een potentiele macht is, kan ieder voor zich zelf nagaan aan het model wan ja- of nee-stellingnamen in een gesprek. " De gemeenschappelijke overtuiging die ontstaat door de acceptatie door de gesprekspartners van criteria voor waarheid, juistheid en waarachtigheid die in de modus van het gesprek zelf zitten, impliceert over en weer een verplichting om ook overeenkomstig die ceiteria te handelen. Bij rechtsvorming kan de kracht van zulke verplichtingen samenvloeien to een potentieel van communicatieve macht waaraan degenen die administratieve machtsposities bekleden niet voorbij kunnen gaan.

In de idee van de rechtsstaat moet de nomatieve veronderstelling van politieke autonomie tot gelding worden gebracht. Dat moet gebeuren tegen de achtergrond van rechtens niet getemde macht die in strijd met het normatief zelfbegrip het recht kan binnen dringen. De inrichting van de rechtsstaat is in deze opvatting een stelsel van fundamenteel open, door ervaring geleide voorzieningen tegen hel onderwerpen wan het rechtssysteen aan niet-

7 Habemus $1902,19.183 \%$

8 Habems 1992, p. 183, met verwizingen nar Hannah Aremd, Vita Activa, Stutgart 1960 en Uber die: Revolution, Mänohen 1965.

9 Arend 1960, p. 194.

10 Habermas $1992, \mathrm{p}, 183$ 
legitiene macht." Zo gezien wordt het modeme recht zowel gakenmerkt door materialisme als door idealisme. Het materialisme kenmerkt een rechtsorde die onder de druk van functionele eisen staat. Het idealisme kenmerkt een rechtsorde die onder voortdurende legitimiteitsdruk staat. Privaat- en publiekrechtelijke instituties maken de inrichting van markten en de organisatie van een staatsapparaat mogelijk. In een legitiene rechtsorde moeten de functionele eisen van economie en staatsapparaat echter gekoppeld blijven aan normatieve eisen van staatsburgerlijke zelfbestemming. In de samenhang van private en publieke autonomie met politieke macht blijft het rech: voor zijn legitumiteit en daarmee voor zijn sociaal-integratieve kracht uiteindelijk aangewezen op de uitoefening van pablieke autonomie door de rechtsgenoten. Deze uitoefening staat of valt met openbarheid.

\section{Openbasarheid}

Voor een harscherpe scheiding tussen de beslotenheid van een private sfeer en de openbaarheid van een publieke sfeer moeten we teruggam tot de polis, de klassieke Griekse stadstaat. ${ }^{2}$ De Griekse polis-idee laat een strikte scheiding zien tussen datgene wat tot een private huishouding behoort - dat is kort gezegd alles wat noodzakelijk is on in leven te blijven - en het "vrije" publieke leven in de polis. Dat laatste is een soort weede leven in een politieke sfeet van gelijken. In het publieke leven speelt zich het politieke af. Dat is vrije actie in de tussenmenselijke samenleving, als deze bevrijd is van het noodzakelijke, de ongelijkheid en dwang die zich in de beslotenheid van de privế huishouding afspelen tussen het hoofd darvan en zijn ondergeschikten: slaven, vrouwen en kinderen.

In de loop van de tijd is de strikte scheiding tussen een private en een publieke sfeer vervaagd. Daarbij heeft het verschijnen van een sociale sfeer een verwarmende rol gespeeld. Deze sociale sfeer, noch prive noch publiek in de klassieke politieke zin van het woord, is een fenomeen dat in de nationale staat zijn politieke vom heeft gekregen. In de sociale sfear schept het levensproces als het ware zijn eigen publicke domein. Aan de ene kant schrompel het privé domein ineen tot een terrein warin nog slechts het uiterst intiene overbliff. Aan de andere kant is ook het zuver politicke niet tegen de constante groel van de sociale sfeer opgewassen. Als een beslissend historisch feit word in dit verband wel gezien de ontdekking van de moderne privacy. Die wordt dan niet gezien als legenovergesteld aan de politieke sfeer mar an de sociale sfeer. ${ }^{13}$

11 Habermas 1992. 0.58.59.

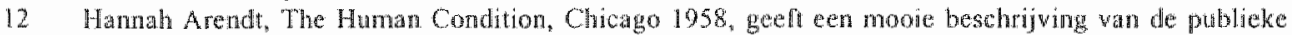

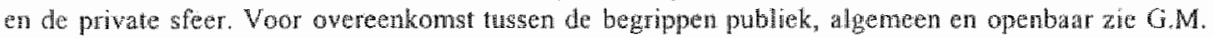
van Asperen, De goode matschappij, Assen 1978, p. 58.

13 Arendt 1958, p. 38-39, geeft jean-Jacques Roussear de eer da ondekker te zijn wan do moderne privacy, stis een soort "rebellion of the heart". 
Het klassieke begrip openbaarheid komt owereen met een voor iedere rechtsgenoot gelijk toegankelijke publieke sfeer wan politieke discussie." In deze openbaarheid wordt over zaken van algemeen belang gesproken en beslist. In de feodale periode maakt dit begrip plaats voor een representatief openbaarheidsbegrip. ${ }^{15}$ Dat is niet meer gebaseerd op publieke discussie. Het komt neer op het kenbaar maken aan het publiek van de mening van het gezag. Participatie van de leden van de feodale gemeenschap beperkt zich tot het als toeschouwers kennis nemen van die mening.

Door de groei van handel en industrie ontstaan netwerken van economische afhankelijkheden die de afhankelijkheid aan feodale heersers doorkruisen. De permanente beurs die in het jaar 1531 in Antwerpen ontstaat is een voorbeeld wan cen markt van een andere aard dan de van oudsher bekende lokale markten onder lokaal gezag. Deze verbreding van de stadseconomie gaat samen met de ontwikkeling van de nationale staat als belastingstaat. Dit vroeg-kapitalisme stabiliseert oude feodale verhoudingen, maar schept tegelijkertijd ruimte voor ontwikkelingen die deze oude gezagsverhoudingen doen afbrokkelen. In deze ambivalentie ontstaat een splitsing van staat en maatschappij die het uitgangspunt is voor het model van burgerlijke openbaarheid.

Het model van burgerlijke openbaatheid is opnieuw, als het klassieke Griekse polismodel, gebaseerd op een strikte seheiding tussen een publieke en een private sfeer. Openbaarheid heeft niet meer als in de feodale tijd het karakter van het tonen van de grootheid van het gezag. Openbaarheid krijgt de functie wan vrije publieke discussie over maatschappelijke normen. Het publiek (de tot publiek verzamelde private personen) treedt in dit model op als spreekbuis van maatschappelijke behoeften en als drager van de operbare mening. Dit burgerlijk begrip openbaarheid houdt in dlat het publiek de legitimiteit van wetten bediscussieert en dat an het publiek rekenschap afgelegd dient te worden van overheidsbesluiten. Om de macht en met name ook het geweldmonopolie te legitimeren moet de overheid door middel van argumenten de burgers overtuigen van de juistheid van alle overheidsmaatregelen. ${ }^{16}$

Het op een strikte scheiding van private en publieke sfeer gebaseerde model van burgerlijke openlsaarheid wordt minder houdbaar naarmate deze sferen in de werkelijkheid steeds verder verstrengeld raken. In de hierboven al ter sprake gekomen sociale tussensfeer doordringen een vermatschappelijkte publieke sfeer en een verstatelijkte private sfeer elkaar zonder tussenkonst van een politiek discussiërend publiek. Aan de ene kant ontstaan verbanden die zonder algemene discussie gemeenschappelijke private belangen direct willen omzetten in politiek. Aan de andere kant gaan politieke partijen zich door

In deze beschrijwing volg the het 1962 verschenen onderzoek van Habermas, Strukturwandel der Orfentichkeit, 15. Auflage, Damstadt, Netwied 1984. Habermas stileert diarin de socialstalelijke transfomatie van liberale elementer van het type "burgenlijke openbarheid".

16. Ziv over idee en ideologie van burgerlike openbaarheid Habermas 1984/1962, p. 112-171. Daarin bespreskt hij ondier meer publiciteit als bemiddelend principe van politick en moraal bij Kant, de dialectiek van openbarheid bij Hegel en Marx en de ambivalente opvating van openbararheid in de theorie van het liberalisme bij John Stuart Mill en Alexis de Tocqueville. 
samensmelting met overheidsorganen bówen de openbaarheid stellen in plats van te opereren als instrument van de openbaarheid. Naarmate dat gebeurt kont de positie wan burgers als volwaardige rechtsgenoten in het gedrang. Openbaaheid verwordt dan tot een quasiopenbaarheid in een van bovenaf gemanipuleerde gespreksituatie. "De menselijke waardigheid en vrijheid dreigt zo tot op het bot te worden uitgebeend."17

Bij de korte beschrijving van thet model van burgerlijke openbaarheid lijkt "het publiek" als drager van de openbare mening een feitelijke verzameling van alle burgers die collectief drager zijn van "de" openbare mening over alle mogelijke politieke kwesties. Daarbij komt dat dit model uitgaat van een burgerlijke maatschappij die de door arbeids", kapitaalen goederenmarkten gestuurde economie insluit. In hedendaagse samenlevingen is zo'n model onhoudbaar. Maar daarmee is de notie van burgerlike openbaarheid niet verdwenen. Integendeel, in onze moderne complexe samenlevingen is deze opnieuw tot leven gekomen. ${ }^{18}$

Een eigentijdse versie van burgerlijke openbaarheid is niet meer gekoppeld aan een burgerlijke maatschappij zoals die naar liberale traditie met de groei van handel en industrie opkwam. Hoewel de huidige burgerij in de kern verbonden blijft met de economische aspecten van de samenleving hebben burgerij en economie zich tot op zekere hoogte ten opzichte van elkaar verzelfstandigd, zoals dat ook met burgerij en overheid is gebeurd. In een sociale sfeer is als het ware een maatschappijbrede burgerlijke openbaarheid ontstaan die well met staat en economie verbonden is maar er niet door wordt opgeslokt.

Min of meer afgegrensd wan staat, economie en andere functionele maatschappelijke systemen doen vrijwillige associaties dienst als fora voor publieke discussie over maatschappelijke problemen op uiteenlopende schaal en levensgebieden. In de sfeer van vrijwillige associaties manifesteert burgerlijke openbaarheid zich in min of meer spontaan ontstane groepen, verenigingen, (protest)bewegingen. Deze associaties vertalen de gevolgen van maatschappelijke problemen in het leven van alledag naar de officiële politieke openbaarheid. Deze herontdekte burgerlijke openbaarheid is te beschrijwen als een netwerk voor de communicatie van meningen."

In het hier woorgestelde model zijn communicatiekanalen van de openbaarheid zodanig aan de private sfeer - van familie en vriendenkring, contacten met buren, collega's en bekenden - angesloten, dat communicaties geleidelijk verbreed en abstracter worden zonder dat de onderlinge verstandhouding verloren gaat. Zo kan de oriëntering op de praktische verstandhouding van het alledagse gesprek behouden blijven voor communicaties onder vreemden die in complex vertakte openbaarheden over verre afstand gevoerd worden. In deze opvatting van burgerlijke openbaarheid wordt de drempel tussen private

17 Aldus cen karakteristiek die Van Bers 1984, p. 15, geeft van het betoog van Habemas op dit pnant.

18 Habermas 1992, p. 443.

19 "Dic Offentlichkeit laszt sich am ehesten als ein Netzwerk fur die Kommunikation won Inhalter und Stellungnahmen, also von. Aeinugen beschreiben; dabei werden die Kommunikationsflisse so gefil. rert und synthetisiert, dass sie sich zu themenspezifisch gebundehen offenthchen Moningen verdichten." Habermas 1992, p. 436, met cursiveringen van Habermas. 
sfeer en openbaarheid niet gemarkeerd door bepaalde thema's of betrekkingen, maar door het varierren van de woorwaarden voor de toegankelijkheid tot communicaties. Deze voorwaarden waarborgen aan de ene kant de intimiteit en aan de andere kant de publiciteit van communicaties. Ze sluiten de private sfeer echter niet tegen de openbaarheid af. Ze kanaliseren slechts de stroom van thema"s uit de ene sfeer in de andere. Op deze manier krijgt de openbaarheid impulsen uit de private verwerking van de neerslag van maatschappelijke problemen in het leven van alledag. ${ }^{20}$

Uit democratisch oogpunt moet burgerlijke openbaarheid méér zijn dan een waarschuwingssysteem met een maatschappijbrede gevoeligheid. Maatschappelijke problemen moeten niet alleen in de openbaarheid waargenomen en geidentificeerd worden. Ze moeten ook zo overtuigend en invloedrijk gethematiseerd worden dat ze als communicatieve macht door het parlementaire politieke proces overgenomen en verder bewerkt kunnen worden. Doordat het publiek als drager van de openbaarheid samengesteld is uit leken, is de burgerlijke openbaarheid ingesteld op een niet gespecialiseerd alledaags taalgebruik. Ze is niet specifiek betrokken op bepaalde functies of op bepaalde inhouden van communicatie. Ze kenmerkt zich eerder door betrokkenheid op een derde aspect van communicatie: de sociale ruimte die in een aan onderlinge verstandhouding georiënteerd gesprek ontstaat.

In een optiek van private en publieke autonomie is de kwaliteit van openbaarheid en daarmee ook van recht afhankelijk van de manier waarop rechtsgenoten omgaan met de sociale ruimte die ontstaat bij het uitoefenen van hun publieke autonomie. Maar is de veronderstelling van het bestaan zélf van sociale ruimte reëel? Zit er voor gewone burgers in de politiek en irh de rechtspraktijk iets anders op dan genoegen nemen met de eerder besproken quasi-openbaarheid? In een rechtsorde waarin burgers hun publieke autonomie structureel niet kunnen uitoefenen kan geen sprake zijn van sociale ruimte en is de kwaliteit van recht afhankelijk van de willekeur van machthebbers. Dat mag duidelijk zijn. Iets. anders is het als burgers hun publieke autonomie orm welke reden dan ook niet willen uitoefenen. Dat staat hen vrij. Net als bij het uitoefenen van private autonomie verdraagt communicatieve vrijheid zich ook bij het uitoefenen van publieke autonomie niet met dwang. Dat rechtsgenoten door géen gebruik te maken van hun mogelijkheden tot uitoefening van publieke autonomie het rechtskarakter van hun rechtsorde op het spel zetten illustreert de innerlijke kwetsbaarheid van een consequent aan vrijheid georiënteerde democratische rechtsordening.

\section{Openbaarheid en gesprek in de rechtszaal}

Evenals het onderzoeksthema zelf is de gedachte aan gesprek als model van het doen van recht primair bij mij opgekomen in de context van recht spreken. Als een historische oervorm van recht doen lijkt rechtspraak ook een voor de hand liggend uitgangspunt voor 
een theoretisch raamwerk. "Maar het associëren van archaïsche vormen van rechtspraak levert met het oog op het open gesprek niet direct succes op. Het roept eerder beelden op van een pater familias, een stamhoofd of een rechter-koning die om tol een uitspraak te komen eerder met god(en) "in gesprek" gaan dan met de rechtsgemeenschap en met direct betrokken partijen.

In onze tijd is juist het vermijden van ledere vorm van buiten- of boven-menselijke rechtvaardiging een vereiste van deugdelijke rechtspraak. En: toch, komt vandaag de dag een "gesprek" van de rechter met de rechtsgemeenschap niet ongeveer op hetzelfde neer als in oude tijden het "gesprek" van de rechter met goden? Als thet "gesprek" in beide gevallen even ongrijpbaar en daardoor immum is voor kritiek dan lijkt het daar inderdaad op. En hoe staat het met direct betrokkenen? Is het gesprek in de rechtszaal, zéker op het gebied van het strafrecht, niet eerder te karakteriseren als "dwangcommunicatie" dan als open gesprek? ${ }^{22}$.

Mij lijkt dat de verdachte in het strafproces inderdaad vaak "wordt genoodzaakt in te stemmen met feitelijke en normatieve presupposities die aan de taalhandelingen van de rechter ten grondslag liggen en die de verdachte nauwelijks de gelegenheid bieden om een eigen visie naar voren te brengen." ${ }^{23}$ Deze door Bal geschetste realiteit van dwangcommunicatie in de rechtszaal trek ik niet in twijfel. Integendeel, een model van recht doen als open, kritische discussie is juist bedoeld om praktijkgericht stelling te kumnen nemen tegen de realiteit van ontbrekende of gebrekkige discussie in het juridisch proces over (de uitleg van) feiten en normen. ${ }^{24}$ Ook Bal zelf pleit met het oog op de realiteit in de rechtszaal voor een strafproces dat open staat voor een kritische en fundamentele discussie.

Dat een theorie waarin recht doen wordt opgevat als kritisch "gesprek" ook ongeduldige weerstand oproept mag duidelijk zijn. Daarvan getuigt het wolgende citaat uit een kritiek op Habermas' discourstheorie van het recht. 'De werkelijkheid van het recht is echter niet die van het gesprek, maar van de rechtszaal, de politie en de kleine lettertjes van een contract. Het is tijd om dit legitimiteitsvraagstuk van de rechtstheoretici te koppelen aan de alanvaardbaarheidsvragen van de betrokkenen." ${ }^{25}$ Dat laatste is precies wat ik in deze studie probeer te doen.

In het perspectief van "aanvaardbaarheidsvragen van betrokkenen" in de rechtszaal gebruik ik hierna in een korte schets de begrippen "begrijpelijk" en "zinvol", die hier ook op te vatten zijn in de betekenissen van legaliteit en legitimileit. Rechterlijke beslissingen

21 Ch. Enschedé, De burger en liet rech, Ansterdam 1988, p. 48, typeer rechtsprakak als "de moeder van hei recht."

22 P. Bal, Dwangcommunicatie in de Rechtszal, Arnhem 1998.

23 Peter Bal, Wat draagt Habemas bij tot de ontwikkeling wan een discourstheorie vant hat straf(proces)recht?, Recht en Kritiek 1994, p. 152-169, p. 160-161.

24 Vgl. het opstel Recht als knitische discussic, in de gelijknamige bundel opstellen van A. A. Peters, Arnhem 1993 .

25 Erhard Blankenburg, De legitimiteit wan het recht ligt on wat het doet, Kech en Krituek 1994, p. 145151. p. 147 


\section{Hoofdstuk 3}

moefen woor betrokkenen begrijpelijk én zinvol zijn. Dat is het uitgangspunt. Het criterium woor het begrijpelijke is hier de samenhang van hef geheel van rechtsmomen binnen een bestaande rechtsorde. Bij dat criterium ga ik aan de grondslagen van $\mathrm{z}^{\circ} \mathrm{n}$ rechtsorde voorlopig voorbij. Het gaat erom dat rechtspraak voor betrokkenen (h)erkenbaar moet zijn als passend in de rechtsorde als geheel. Maar als een rechterlijke beslissing voldoet aan dit technisch criterium van coherentic binnen het systeem, dan is het nog niet een "goede" beslissing. Het recht(vaardigheid)sgehalte betreft ook het zinvolle van een beslissing. ${ }^{2 h}$ Dat heeft te maken met de feitelijke en normatieve betekenis die de beslissing heeft voor individuele rechtsposities en voor de samenleving waarin ze genomen wordt. Voor het zinvolle hanteer ik hier het criterium: op goede gronden algemeen aanvaardbaar. Daarbij gat ik ervan uit dat de beslissing in beginsel de vrije instemming moet kunnen krijgen niet alleen van direct betrokkenen maar ook van ieder lid wan de betreffende recintsgemeenschap. Deze instemming heeft betrekking op datgene wat de beslissing concreet betekent voor mensen, met het oog op uiteenlopende belangen en gedeelde of verdeelde voorstellingen van normen en waarder in de samenleving.

Veronderstellen dat rechterlike beslissingen voor ieder ook concreet te begrijpen zijn zodra ze naar het oordeel van de rechter aan het criterium van coherentie voldoen, is niet reëel. Integendeel, rechterlijke uitspraken zullen vaak niet alleen voor de juridische leek maar ook voor de aankomende, onervaren of niet gespecialiseerde jurist in eerste instantie onbegrijpelijk zijn. Mogelijke oorzaken daarvan zijn niet wer te zoeken. Denk maar aan steeds complexer wordende regelsystemen ${ }^{27}$ of an soms zeer ingewikkelde typisch juridische redeneringen. ${ }^{2 B} \mathrm{Om}$ zo"n complexe juridische gang van zaken echt begrijpelijk te maken zal de jurist zich moeten inleven in de belevingswereld van mensen die anders dan juridisch-professioneel bij de kwestie betrokken zijn. Daarbij spelen ook andere factoren een rol dan het ingewikkelde van juristerij. De context en het partijperspectief zijn zulke factoren. ${ }^{29}$ De "bril" waarmee mensen naar bepaalde feiten en gebeurtenissen kijken kan tot sterk uiteenlopende waarneming en interpretatie daarvan leiden. Voor de juridische beoordeling wan het conflict is dan uiteraard van groot belang welke voorstelling als maatgevend wordt beschouwd. ${ }^{30}$

26 In de soeiologie is het gebrikelijk on op basis wan het begrip "zin" eev ondersicheid te maken tussen "houdelen" en "gedrag". Zie Tamelie Blom, Zin en systeem, in Tijdschrift woor Sociale Wetenschappen 1086, p. 23-53, ook over het begrip "zin" in de systeemtheorie wan Luhmann. In het begrippenpar begrijpelijk en zimol gebruk ik het begrip zin in een mimere, nomatieve betekenis (⿻ivic overeenkont met legitimiteit.

27 M.G. Rood, Over de zwarte van de rechtenstudie, NIB 1992, p. 157 160, schrift: "De explosie van juridische regelgeving door nationale en intemationale wetgevers en doot rechisprak heeft de zwarte van de juridische studie ingrijpend behnvloed. Was rechten jaren terug een relatief lichte studie, dat is radichal woorbif." Zie p. 159.

28 Zie M.J. Cohen, Over het denken wan juristen, Nieuwenhoflezing V. Deventer 1992, voor typen redeneringen die juisten plegen te hanteren.

29 Cohen 1992, p. 9 v.

30 Cohen 1992, p. 10 beschijn het partipperspectief als een essentide deteminant voor de wijze warop aen juridisch conflic behandeld word. "In buitengewoon veel gevallen is het vaststellen van de feiten de slentel voor de (juridische) oplossing wan het conflict: slag je erin joux presentatie van de feiten voor de rechter anmemelijk te maken, dan heb je de zaak gewonnen, ondat in dat geval meer dan én 
Om zijn beoordeling van het geschil werkelijk begrijpelijk te maken zal de rechter allereerst de moeite moeten nemen zich te verplaatsen in de belevingswereld van partijen. Ook zal de rechter moeten bereiken dat partijen dat over en weer tot op zekere hoogte ók doen. En tenslotte zal het oordeel van de rechter begrijpelijk moeten zijn vanuit de optiek van de werking van het juridisch systeem. Van de rechter wordt hier een betrokken "onpartijdigheid", een soort "alpartijdigheid" gevraggd. Een (te?) moeilijke opgave.

Als hiervoor de indruk is gewekt dat het nemen van een technisch begrijpelijke beslissing uitsluitend te maken heeft met het verstandelijk oordeelsvermogen van de rechter dan is dat een eenzijdige voorstelling. Verstand en gevoel zullen in de praktijk van het recht net zo min solistisch kunnen optreden als bij andere activiteiten in het leven van alledag. Ook bij een primair op samenhang binnen een rechtsstelsel gericht juridisch beslissen komt méér kijken dan verstandelijke kennis van rechtsregès en technische kunde in de omgang daarmee. Het ontstaan en het voortbestaan van conflicten en het oplossen of beslechten ervan is een deel van het leven van mensen. Net als bij andere vormen van leven zijn ze daarbij met hun verstand, gevoel, wil, kortom met hun hele persoon betrokken. Uiteraard zal de intensiteit varn de werking van verstand en gevoel per activiteit aanzienlijk kunnen en ook moeten verschillen om de activiteit naar behoren te kunnen uitvoeren. Wie zou niet zijn hart vasthouden voor een hartoperatie waarbij de chirurg zijn hoofd niet koel houdt en zeer geëmotioneerd betrokken is? ${ }^{32}$ Ook van de rechter mag verwacht worden dat hij bij zijn oordeelsworming het hoofd koel houdt. Maar dat wil niet zeggen dat het gevoel dan afwezig is. Ook bij de uitvoering van een "verstandelijk" karwei zijn intellectuele én gevoelsmatige vermogens steeds gelijktijdig in het spel. Deze vermogens zijn weliswaar analytisch te scheiden en het kan verhelderend en nuttig zijn om dat te doen. In concreto zijn ze hooguit te onderscheiden, niet te scheiden.

De gedachte aan analytische ontkoppeling van verstand en gevoel komt niet toevallig op als overgang tussen bespreking van het begrijpelijke en het zinvolle. Bij de gedachte aan het zinvolle komt als vanzelfsprekend uit de schaduw van het rechtsdenken het rechtsgevoel voor het voetlicht. Maar wordt het zinvolle door een koppeling aan het recht(valardigheid)sgevoel niet in één klap gedegradeerd tot een praktisch niet te hanteren criterium? Immers, het rechtsgevoel is "wel een zeer ruim en, om het zacht te zeggen, niet org precies gedefinieerd begrip." ${ }^{33}$ Laten we aamemen dat bij een oordeel over (on)aanvaardbarheid, over het zinvolle van een juridische beslissing, inderdaad het rechtsgevoel een niet, althans veel moeilijker weg te denken rol speelt dan bij het nemen van cen begrijpe-

Inogelike toepasselijke rechtsregel in refielijkheid nie te vinden is."

31 Het woord "alpartijdig" is wok te vinden bij Wibren wan der Burg, Het democratisch perspectef, Amhem 1991. In hoofdstuk 4 gal ik daar verder op in.

32 Zie voor een psychologische theorie van de emotie Nico H. Frijda, in de bundel Gevoel en emotie, onder redactie van Marten van Nierop, Delft 1985, p. 73-95. In dezelfde bundel Heleen J. Pott, De rationalite tan emoties, p. 39-61. Zie over de objechiviteit wan wardeoordelen J.C. Hage, in Intene en exteme analyses van recht, red. IM. Kanderman en N.H.M. Roos, Zwolle 1988, p. 49-66.

33 Cohen 1992, p. 9. Maar war het om gaat, sehrijft Cohen in dit verband "en dat is wezenlijk in het domein van het recht, is dat eventuele onamvardbaarheid van een bepaalde beslissing tot gewolg kan hebben dat men gatat zoeken naar een andere oplossing, en dat die andere oplossing ook niet ondenkbatar is." 


\section{Hoofdstuk 3}

lijke beslissing. ${ }^{34}$ Om zicht te krijgen op het zinvolle lijkt het dan nuttig dat we ons het werk voorstellen wan een rechter wiens rechtsgevoel expliciet aan het werk is. Welru, de rechter zal de zwalarte van aangereikte argumenten voor of tegen een bepaalde beslissing moeten wegen, specifiek met het oog op "goede gronden". Maar woórdat hij aan wegen toekomt zal hij met een scherp oor voor het "goede" wan gronden naar de argumenten van partijen moeten laisteren.

Hoe werken luisteren en wegen met het oog op het niet alleen begrijpelijke maar ook zinvolle van rechterlijke beslissingen? Is het daarbij mede varen op het kompas van het rechtsgevoel niet een (al te?) hachelijke onderneming? Bij het bekjjken van theorieën over rechterlijke rechtsvinding walt op dat deze zich vooral richten op het versterken van het intellectuele element. ${ }^{35}$ Onbegrijpelijk is dat niet. Het gevoelsleven lijkt meer op zijn plaats in huiselijk en ander particulier verkeer. Het toelaten ervan in het juridisch discours lijkt niet verstandig, met name met het oog op de kwaliteit van recht. Zelfs iemand als Wiarda, die het intuitief zedelijk element in het recht uildrukkelijk positief waardeert, pleit ervoor om een als gewetensbeslissing aan te merken intuïtieve "gedachtensprong" die bij de uiteindelijke keuze van het doorslaggevend argument objectief en rationeel niet verder kan worden verantwoord, "niet groter te doen zijn dan onontkoombaar is." Vrouw Justitia een gevoelsarm verstandsmens?

Laten we de metafoor van Vrouw Justitia even aanhouden, als ideaalmodel. En laten we haar uitrusten met in evenwicht zijnde gelijkwaardige vermogens vam denken, voelen en willen. Hoe zal ze haar weegschaal hanteren? Voorlopig zal ze die laten rusten, om te luisteren naar parlijen. ${ }^{37}$ En als ze dat doet zijn we bij een belangrijk punt in het verhaal. Het luisteren van Justitia wijst rechtstreeks naar recht doen als een vorm van gesprek die gericht is op het nemen van niet alleen technisch begrijpelijke, maar ook in moreel opzicht zinvolle beslissingen.

Als tussen partijen onderling een gesprek over een praktisch probleem dat tussen hen gerezen is niet op gang komt of afgebroken wordt, dan gat Justitia op juridisch niveau met partijen "in gesprek". Justitia luistert naar de vragen van partijen en de voorstelling van zaken die zij geven. Waar de voorstellingen die partijen geven tegenstrijdig zijn zal ze al luisterend en vragend onderscheid moeten proberen te maken tussen ware en onware beweringen over fetten en gebeurtenissen, tussen juiste en onjuiste normatieve voorstellin-

VgI. H.F.M. Crombag, J.L. de Wijkerstooth en M.J. Cohen, Een theorie over reclaterlike beslissingen, Groningen 1977, p. 91. De anteurs achten het "onvermijdelijk dat beslissende rechters hun subjectieve rechtwardigheidsgevol, een toch niet weg te redeneren psychologisch fenomeen, blijwen wergelijken mot door hen berikte systeemonsistente resultaten."

352 zals Crombag/De Wijkerslooth/Cohen 1977 en A.H. de Wild, De rationalitett van het rechterijk oordeel, Deventer 1980 .

36 G.J. Wiarda, Drie typen van rechtsvinding, Zwolle 1980, p. 109-110.

37 Vgl hddst. 2, par. 4, over het met elkar spreken en naar elkar luisteren in een wedarkerige relatie. Zie ook Van Velthoven 1988, p. $109 \%$, over luisteren in thet kader van de intersubjectiviteit van het kennen. Hij wijst erop dat voor echt luisteren is vereist "dat we ons openstellen voor het andere om het zo ongehinderd mogelijk te verstaan, dat we het andere zo tot ons toelaten dat het in dit contact zichzelf kan zijn" (p. 109). 
gen, tussen waarachtige en onwaarachtige witingen van persoonlijke ervaringen en intenties. En tenslotte zal zij moeten wegen en haar antwoord, haar oordeel, moeten rechrvardigen.

Goede gronden als basis voor een algemeen aanvaardbare beslissing kunnen zowel primair via het (rechts)verstand als primair via het (rechts)gevoel opkomen en als zodanig erkend worden. Het laatste kan bijwoorbeeld het geval zijn als deenemers an een discussie rechtstreeks de zwaarte aanvoelen van belangen en warden die in het geding zijn. Zo gezien is het rechisgevoel van Justitia en andere deelnemers aan het gesprek niet een aitshitend psychologisch fenomeen. Als het in een gespreksituatie dialogisch functioneent is het met slechts een persoonlijk, subjectief gevoel. Het is dan ók tussenpersoonlijk, intersubjectief, een sociaal gevoel. En als dat zo is, dan kan lnet kritisch potentieel wan het zo opgevatte rechtsgevoel mee richting geven aan communicatief rationele besluitworming. In ieder geval zweeft Justitia dan niet in haar eentje als een soort rechtwardige godin bóven partijen en hanteert zij evenmin genadeloos haar rechmatigheidssabel. $Z i j$ is gesprekspartner náast partijen. Zij leidt weliswaar het gesprek en zij neent ar met een specifieke reflecterende instelling aan deel. Dat neent niet weg dat Justitia deelnemer is aan het gesprek, niet een uitsluitend observerende waamemer of strategisch rationele beslisser. Een actief onpartijig en in die zin "alpartijig" perspectief is de basis van een evenwichtige rechterlijke werkwijze van Justitia. Dit perspectief is de basis van rechterlijke beslissingen die niet alleen begripelijk maar ook in sociaal en moreel opzicht zinvol willen zijn.

\section{Dimensies van rationeel handelen}

Het geschetste beeld van Vrouw Justitia past in een model wan een ideale communicatiegemeenschap die drijf op communicatieve rationaliteit, waarbij verstand, gevoel en will evenwichtig aan bod komen. In het leven van alledag en dus ook in de juridische werkelijkheid ziet het er anders uit. De rechter zal meestal hooguit serieus rekening kumen houden mel standpunten wan partijen. Oorzak van deze discrepantie is niet in de cerste plaats een gebrek aan communicatieve competentie van een werkelijke beslisser in vergeljking met de ideale Justitia. Integendeel, zo lang conflicterende partijen niot geinteresseerd zijn in een gesprek dat gericht is op overecnstemming tussen hen over de interpretatie van foiten en de gelding van normen, mar uitsluitend oog hebben voor het hoe dan ook halen van hun gelijk, staat iedere beslisser op communicatief niveau machteloos. Het sociaal contact met partijen kan dan niet anders plats hobben dan op het strategisch handelingsniveat warop partijen opereren.

In een levensecht juridisch discours valt niet over alles te discussieren. Dat is op zich zelf geen probleem. Integendeel, het is logisch onmogelijk om alles tegelijk ter discussie te stellen. ledere discussie vooronderstelt een gedeelde achtergrond die niet in zijn geheel gelijktijdig bespreekbaar is. Maar ook praktisch inhoudelijk gezien is het juridisch discours er juist op gericht om binnen redelijke termijnen tot besluiten te komen, tot een (voorlopige) afsluiting van het gesprek. Problematisch wordt het pas als "discussieloze" beshitvor" ming leidt to in de samenleving in het algemeen en door betrokkenen in het bijzonder niet 


\section{Hoofdstuk 3}

als zinvol te aanvaarden beslissingen. Zinvolle beslissingen zijn afhankelijk van reële ruimte voor redelijke discussie over betrokken belangen, waarden en normen. Die discussie hoeft overigens niet op ieder institutioneel niveau telkens opnieuw plaats te hebben. Naarmate op het niweau van wetgeving algemene normen van samenleving in meer substantieel democratische verhoudingen tot stand komen en een breder draagvlak hebben in de samenleving, zal er op het niveau van rechtspraak in een concreet geval minder draagylak zijn om deze normen zêlf ter discussie te stellen. Toch zal de rechter ook dáárvoor steeds de ruimte moeten bieden, naast de rumte voor rationele communicatie over de vraag of toepassing van op zichzelf algemeen aanvaardbare normen in een gegeven geval adequaat is.

Laten we nu in samenhang met het voorgaande het op verschillende manieren gebruikte begrip rationaliteit wat nader bekijken. Voor het bereiken van technisch begrijpelijke rechterlijke beslissingen kan volstaan worden mer een strategische, direct doelgerichte rationele discussie en met een technisch-instrumentele toepassing van regels. Het effectief bereiken van het gestelde doel, hier een in het rechtssysteem in te passen technisch begrijpelijke beslissing, bepaalt de rationaliteit van het rechterlijk handelen. Voor het bereiken van een niet alleen begrijpelijke maar aok zinvolle beslissing is méér nodig. Het criterium van het zinvolle eist een morele "alpartijdigheid" die niet te bereiken is met een louter doelrationele benadering van het op te lossen of te beslechten probleem. Morele "alpartijdigheid" eist dat alle potenticel goede gronden met het oog op het in geding zijnde probleem door betrokkenen naar voren gebracht kunnen worden en door de rechter als een oprechte deelnemer aan het "gesprek" serieus gemotiveerd worden verwerkt. Datt eist communicatief rationeel handelen.

Het onderscheid tussen instrumenteel, strategisch en communicatief handelen kan gemaakt worden door aan de ene kant te letten op de aard van de handelingssituatie en aan de andere kant op de oriëntatie waarmee gehandeld wordt. ${ }^{38}$ Om te beginnen met de handelingssituatie: strategisch en communicatief handelen zijn sociaal van aard, instrumenteel handelen is niet social van aard. Instrumenteel handelen kan wel nauw verweven zijn met sociale interactic, maar is zelf geen sociaal handelen. Het betreft een eenzijdige relatie tussen cen subject en een te bewerken object. Strategisch en communicatief handelen daarentegen zijn zelf vormen van sociaal handelen.

Wat de handelingsoriëntatie betreft: instrumenteel en strategisch handelen zijn vormen van succesgeoriënteerd handelen. Een doelgericht subject stat tegenover een voor dat doel te bewerken object (instrumenteel handelen) of subject (strategische interactie). Succes wordt gedefinieerd als het effectief bereiken van een gewenste toestand, die in een gegeven situatie door doelgericht doen of laten causaal bereikt kan worden. Instrumenteel handelen richt zich voor het bereiken van een bepaald doel naar technische regels. De effectiviteit wordt beoordeeld naar de samenhang van toestanden en gebeurtenissen. Strategisch handelen richt zich voor het bereiken van een bepaald doel naar een rationele keuze uit hande- 
lingsalternatieven. De effectiviteit wordt beoordeeld naar het belmwloeden van de beslissingen van een rationele tegenspeler. Het gaat hier om varianten van een producerend type handelen dat al in het vorige hoofdstuk ter sprake is gekomen. ${ }^{39}$

Communicatief handelen is niet georiënteerd op eigen succes maar op onderlinge verstandhouding. Een in onderlinge verstandhouding bereikte overeenstemming berust op gemeenschappelijke overtuigingen. Ze katn niet opgelegd worden, noch instrumenteel door een directe ingreep in de handelingssituatie, noch strategisch door een berekende beinwloeding van besluiten van een tegenpartij. ${ }^{\text {to }}$. De oriëntatie op onderlinge verstandhouding houdt overigens niet in dat bij communicatief handelen doelgerichtheid taboe zou zijn. Dat zou ook praktisch niet mogelijk zijn. Alle handelen kan op een of andere manier als doelgericht worden beschouwd. De gerichtheid op onderlinge verstandhouding houdt wel in dat de deelnemers aan communicatief handelen niet primair aan het eigen succes georienteerd zijn. Als individuele doelen nagegaan worden, dan gebeurt dat onder de voorwaarde dat de deelmemers hun handelingsplannen op basis van gemeenschappelijke situatiedefinities op elkaar kunnen afstemmen.

Bif commumicatief rationeel handelen zijn mensen voor het bereiken van een doel gebonden aan normen waarvan de gelding afhankelijk is van onderling begrip en wederzijdse instemming. Bij dit type handelen heeft rationaliteit vóór alles te maken met het fundamenteel kritiseerbare van uitingen en met bereidheid tof rechtvaardiging van alles wat gezegd kan worden. De criteria voor communicatieve rationaliteit zijn, Habermas wolgend, warheid, juistheid en waarachtigheid. In deze optiek staat rechtsvorming niet alleen consequent open voor waarheid ten aanzien van feiten en gebeurtenissen. Ze staat ook open voor juistheid van op goede gronden algemeen aanvaardbaar geregelde nomatieve betrekkingen tussen mensen en voor waarachtigheid van persoonlijke ervaringen en intenties. Deze opvatting van de rationaliteit van communicatie bevestigt dat niet alleen het rechtsverstand van Vrouw Justitia maar ook haar rechtsgevoel als sociaal gevoel te maken heeft met rationalitent.

In een ruime betekenis onvat het begrip rationaliteil zowel insirumentele en strategische als communicatieve rationaliteit en vormen de drie dimensies van conmunicatieve rationaliteit (waarheid, juistheid en waarachtigheid) onderling éen geheel. Historisch gezien hebben echter ontwikkelingen plaats gehad waardoor de term rationaliteit praktisch uitsluitend nog in verband met instrumentele en strategische doelrationaliteit en in verband met communicatieve waarheidsaanspraken wordt gebruikt. Communicatief rationele aanspraken van normatieve juistheid en persoonlijke waarachtigheid zijn op de achtergrond geraakt. Dat heeft geleid tot het loskoppelen van criteria van effectiviteit en problemen van rechtvaardigheid. ${ }^{4 !}$ 


\section{Hoofdstuk 3}

\section{De ontkoppeling van systeem- en leefwereld in het recht}

Het laskoppelen van doelrationaliteit en problemen van rechtvaardigheid heeft de capaciteit om problemen op te lossen aanzienlijk vergroot. Direct doelgericht, optimaal gebruik van hulpmiddelen kan de enorme vooruitgang verklaren op terreinen als goederenproductie en beheersing van de natuur. Ook de groeiende verzelfstandiging van economie, recht en politiek, ieder met eigen organen en instanties, regels en wetmatigheden, kan hierdoor worden verklaard. Maar deze loskoppeling levert op het gebied van probleemoplossing ook nadelen op. Als een probleem dat met rechtwaardigheid te maken heeft bijworbeeld wordt teruggebracht tot een probleem dat met een efficiënte procedure van afdoening te maken heeft, dan ligt het voor de hand dat personen, die direct bij dat rechtvaardigheidsprobleem betrokken zijn, gedesoriënteerd raken. In Habermas" terminologie: systeem- en Leefwereld sluiten niet meer op elkaar aan. In de rechtspraak gebeurt dat als de inhoudelijke vraag of een uitspraak "juist" is (in een betekenis wan rechtvaardig), vertaald wordt in de procedurele wraag of de uitspraak "juist" is (in een betekenis van het formeel juist tot stand komen van de uitspraak). In zo'n formeel procedurele benadering wordt het onderliggende moreel-praktisch probleem aan het zicht onttrokken. Dat is precies wat in mijn ogen gebeurt als iemand wiens aandacht uitgaat naar het praktisch probleem waar het eigenlijk on gaat bij een technisch-rationele beslechting verbaasd vraagt: "Is dit recht?"

Als we kwesties van morele rechtvaardigheid in het recht willen behandelen en tegelijk integraal willen vasthouden aan eisen van rationaliteit, zal het rationaliteitsbegrip daarvoor de nodige ruimte moeten bieden. ${ }^{42}$ In een gespreksmodel wan recht als gedemonstreerd aan Vrouw Justitia is deze ruimte ingebouwd. Historisch gezien kan zo'n verruiming gezien worden als correctie op de vernauwing van het begrip rationaliteit die is ontstaan door een steeds verdere mechanisering, op feitelijke beheersing gerichte differentiëring en specialisering. Voor een op normatieve juistheid gerichte verruiming van het rationaliteitsbegrip hebben we Barendrecht al een voorzet zien geven. ${ }^{43}$

42 Vgl. Ton Wilthagen, Recht in een gesloten samenleving, het debat over reflexief recht en autopoiesis, in Recilt der Werkeligkheid 1992, p. 119-138. In een theorie van reflexief recht die zich oriënteert aan de procedure gerichte modellen wan Habermas en Luhmann wordt reflexieve rationaliteit gepresenteerd als een onontkoonbare "derde weg", na de formele rationaliteit van een laissez-fairemarkteco nomie en de materiele rationaliteit van het top down-instrumentalisme van de verzorgingsstat. In teflexief recht en zelfreferentiele of autopoietische systemen, zoals aangepakt en witgewerkt door Teubner, signaleert Wilthagen het ontbreken van een relatie tot een handelingstheorie. Daardoor is volgens hem onduidelijk welke betekenis aan een begrip als "democratisering" moet worden toegekend. De door Teubner in het voetspoor wan Luhmann geschetste "derde weg" -rationaliteit laat ik datron in deze studie terzijde. 


\section{IN ALPARTIJDIG PERSPECTIEF: DRIE BEGINSELEN VAN MENSENRECHT}

\section{Inleiding}

De in het vorige hoofdstuk besproken justitięle openheid in de vorm van "alpartijdigheid" sluit op het eerste gezicht goed aan bij het concept van de daar eveneens aan de orde gestelde democratische openbaarheid. Toch zijn er belangrijke verschillen tussen het alpartijdig stellen van rechtsnormen en het alpartijdig toepassen ervan (par. 2). Deze juridische alpartijdigheid is door Habermas niet vanuit zijn gespreksmodel ontwikkeld. Met het oog op $z 0^{\prime n}$ ontwikkeling loont het wellicht de moeite ten opzichte van Habermas afwijkende concepties van politieke alpartijdigheid te bezien op hun toepasbaarheid op justitiële alpartijdigheid. Die zouden waardevol kunnen blijken voor de ontwikkeling van een bruikbaar concept van justitiële alpartijdigheid, zelfs al zou Habermas' visie van politieke alpartijdigheid als zodanig de voorkeur verdienen. In het bijzonder Van der Burgs visie springt er in dit verband uit, omdat hij ook inhoudelijke nomen verbindt aan "onpartijdigheid". Niettemin zal Habermas" visie op democratische alpartijdigheid adequater blijken, zodat alternatieve concepties van onpartijdigheild in ieder geval geen onmiddellijk soelaas kunnen bieden bij het zoeken naar justitiele alpartijdigheid (par, 3). Het probleem is dan vanuit de idee van mensenrecht de innerlijke relatie tussen private en publieke autonomie nader te bepalen. $\mathrm{k} k \mathrm{kom}$ daartoe op basis van een weerlegging van kritiek op Habermas door Van Roermund en via een pleidooi van Holtmaat voor het verruimen van het concept van subjectieve rechten (par. 4). In samenhang met een perspectief van alpartijdigheid in het gekozen model van het open gesprek zal ik drie aspecten van mensenrecht affeiden: wrijheid, trouw en zorg. Ik stel deze aspecten voor als procedurele en materiële beginselen van behoorlijk handelen in een rechtsorde (par. 5), die zich tevens laten beschouwen als drie beginselen van mensenrecht (par. 6). Of deze drie beginselen bruikbaar zijn als richtsnoer voor het beoordelen wan het rechtsgehalte van "openbare orde", zal dan moeten blijken in het tweede deel van deze studie.

\section{Alpartijdig stellen en toepassen van rechtsnormen}

Hoewel duidelijk is dat mensen zich in werkelijkheid nooit volledig los kunnen maken van hun eigen belangen, vooroordelen en maatschappelijke posities, wordt het inmemen van een moreel gezichtspunt van onpartijdigheid algemeen gezien als een voorwaarde voor het rechtvaardigen van morele uitspraken. Modellen van onpartijdighteid gaan bijwoorbeeld uit van een fictieve morele wetgever (Kant), van een niet partijdige toeschouwer (Baier), van 


\section{Hoofdstuk 4}

een ficticve naturoestand (Rawls) of van een ideale gespreksituatic (Habemas).'

Als rechtspraak in deze studie model staat voor een bepaalde invulling van de notie var aparijdigheid mag dat er not toe leiden dat alparijdige wetgeving en alpartijdige rechtspraak over eén $\mathrm{kam}$ worden geschoren. Als het onderscheid in het niveau van algemeenheid en in de aard van de werkzaamheden wit het oog verloren wordt, komt rechtsbescherming door de rechter op de tocht te staan. Daarmee wil ik niet zeggen dat een rechter bij het oordelen in een concreet geval de algemeenheid van toe te passen regels mag verwaaryozen. Integended, dat zou ten koste gaan van alpartidighey bimen de rechtsorde als geheel. Mij lijkt echter dat bijwoorbeeld nict van de rechter het scherp formuleren van een nieuwe rechtsregel geéist mag worden als een bestaande wetstekst in een gegeven geval geen bevredigende uikomst biedt. Als dat wel van de rechter wordt geejst ${ }^{2}$ dan ligt het voor de hand dat de rechter zodanig wan het voorliggende geval moet abstraheren, dat dit ten koste kar gaan van individuele rechtsbescheming van de rechtszoekende burger. Daarmee gaat het dan tevens ten koste wan hel normatief gehalte van de rechtsorde als gehecel.

Zowel het essentieel onderscheid als de interne samenhang tussen wetgewing en rechtspraak kan geillustreend worden, waar Barendrecht het resultaat van de rationele maatschappelije discussie voorstelt als mogelijk criterium van rechtvaardigheid. Dit woolstel past in een concept van private en publieke autonomie en commumicatieve politieke macht. It hun hoedanigheid van betrokkenen bij de in Jun rechtsorde geldende rechtsnormen zijn rechtsgenoten te beschouwen als awewrs van deze rechtsnonnen. Als rechtsgenoten zijn ze (potenticle) deelnemers an de rationele matschappelike discussie. Geldende rechtsnormen geven de actuele stand van deze maatschappelijke discussie weer. In het proces van rechtsprak daarentegen zijn de direct bij een concreet conflict betrokken partijen primair te beschouwen als adressaten van deze rechtsnomen. De rechter wordt geacht deze rechtmormen als weergave van de actuele stand van deze discussie bij de tijd te brengen en in samenhang met het voorliggende conflict te interpreteren. ${ }^{3}$

Gelet op hun algemeenheid en onbepaldheid kunnen rechtsnomen in concrete gevallen op het cerste oog miet meer dan toepasselijk lijken. Pas in het toepassingsproces zelf kan getoutst morden of deze rechtsnormen ook feitelijk toepasselijk zijn, of ze passen op een gegeven situatie. Als dat niet zonder meet het geval is, dan moeten ze met inachtneming wan hun strekking binmen de rechtsorde als getheel plaats maken woor een doon de rechter aangepaste nom of voor een andere, well passende norm. Bij het alpartijdig stellen van rechtsnornen gaat het om de gelding wan rechtsnomen in het algemeen. Bij hel alpartijdig tocpassen van rechtsnomen gat het erom een geldige rechtsnorm op een gepaste manier"

1 Vander Burg 1991, p. 211.

2 Zic in dit verband ining kommentar bij de theorie van Barendrecht in hoofdstuk twee.

3 Zie over de "trias politica" nict meer als scheiding van wetgevende, rechterlijke en bestwurlijke macht maar als een dymamisch evonwicht van machten W.J. Witteveen, Evenwicht van machten, Zwolle 1991.

4 Habernas 1992, p. 268 w. verwigst in dit verband naar de studie van $\mathbb{K}$. Günther, Der Sinn für Angenessenheit, Frankfurt/Main 1988 . 
op een gegeven situatie te betrekken. In het open gesprek met partien en tegeljk met de rechtsgemeenschap in het algemeen, neemt de rechter een uniek alpartijdige positic in.

In gesprek met de rechter moeten betrokken partijen als adressaten van rechtsnomen verantwoording afleggen en moet de rechter feitelik en juridisch oordelen over een gerezen geschil. Tegelijk is de rechter met dezelfde partijen en met rechtsgenoten in het algemeen "in gesprek" als gezamenlijke auteurs van rechtsnomen. Een overgeleverde verzameling an verandering onderhevige en - als het goed is - in een alpartijdige openbatheid tot stand gekomen rechtsnormen staat de rechter als achtergrond ter beschikking. Matstaf voor de legitimiteit van wetgeving én rechtspraak is in het besproken autonomiemodel het met gelijk gewicht tot gelding brengen wan de private en publieke autonomie van alle rechtsgenoten. Deze maatstaf geldt zowel op het nveau van direct bij het geschil betrokken partijen als tegelijk ook op het niveau van alle rechtsgenoten ge meenschappelijk.

Daarbij moet echter worden bedacht dat een rechter die een nom toepast deze een betekenis verleent op basis van hypothesen over de strekking van de wet. Dit is echter een typisch juridische aangelegenheid. Een rechter reconstrueert een rechtsnorm niet, bijwoorbeeld, in politicologische termen, maar als de uitkonst van een bepaalde afweging van rechtswaarden. Ook als er niet direct een rechtsnom van toepassing is, zal een rechter buiten het strafrecht althans, een nom construeren aanknopend bij nomen die van toepassing ziljn op werwante gevallen. Ook de beoordeling wan de feiten geschiedt typisch onder het gezichtspunt van hoe partijen met de in het geding zijnde rechtswaarden zijn omgegaan. Het is door dit zoekilicht van relevante rechtswaarden dat de beroemde "hermeneutische cirkel" tussen feiten en recht mogelijk is. Partijen hebben veelal strijdige visies op het gewicht van de rechtswaarden en de feiten. Ook het gesprek tussen rechter en partijen over deze zaken speelt zich af in het licht wan deze rechtswaarden en het is in het licht daarvan dat rechter en partijen elkaar kunnen "verstaan" (wat niet noodzakelijkerwijs betekent: het met elkatar eens zijn). Het is, zoals betoogd, de taak wan de rechter deze op een "alpartijdige" wijze te verstaan en te beoordelen.

Gezien het bowenstaande is het duidelijk dat we op zoek moeten nar juridische matstaven voor alpartijigheid nen nar politiek-democratische. Niettemin zullen er relaties lussen beide bestaan als we met Habermas een gelikoorspronkelijkheid van private an publieke autonomie aamemen. Zowel over de betekenis van normen als over de interpretatie van feitelike gebeurtenissen kumnen zich verschillen van visie voordoen waabij nu juist de vragg naar de afgrenzing van vrijheidsrecht, private autonomie, en socianl belang, publieke autonomie, aan de orde is. Waar dethalve behoefte an is zijn matstaven ter bepaling van beide. De juridische alpartidigheid is door Habermas niet vanuit zijn gespreksmodel ontwikkeld. In ferte heeft hij zich beperkt tot een democratic-theoretisch betoog dat private autonomie vooronderstelling is wan publieke autonomie. Hoe celter private en publieke autonomie als rechtsbeginselen samenhangen, heef hij niet nader geanalyseerd, zodat het vooralsnog duister is wat het niet-procedurele, maar inhoudelijk-moreel cognitieve karakter 


\section{Hoofdstuk 4}

is van justitiele alpartidigheid. Om dat te verhelderen loont het wellicht ten opzichte van Habermas afwijkende concepties wan politieke alpartijigheid te bezien op hun toepasbatarheid op justitiele alpartijigheid. Zelfs al zou Habermas' visie op politieke alpartijdigheid de voorkeur verdienen, dan nog zouden deze alternatieve concepties waardevol kunnen zijn voor een nadere invulling van justitiele alpartijigheid.

\section{Alternaticve concepties van alpartijdigheid}

Voor een antwoord op de vraag naar het adequate van een "alpartijdigheid" ả la Vrouw Justitia ga ik om te beginnen nader in op het eerder in hoofdstuk drie ter sprake gekomen democratie-principe wan Habermas. Daama ga ik te rade bij Van der Burg, die in zijn proefschrift over democratie werkt met het begrip alpartijdigheid.

Habermas gaat ervan uit dat een moreel gezichtspunt wan onpartijdigheid an de rechtsvorm twee intuitieve noties zijn van mensen die hun samenleven op een in beginsel door allen op goede gronden wrij anvaardbare manier zo veel mogelijk geweldloos willen regelen. De notie wan de rechtsvorm heef betrekking op de vorm waarin het feitelijk dwingend stellen en handhaven van onpartijdige samenlevingsvomen to urtdrukking komt. De notie van onpartijdigheid is in deze opvatting een eis van algemene aanvardbaarheid van normen wan samenleving. Deze eis komt bij Habemas tot uitdrukking in het eerder kort besproken discours-principe.

Volgens Habermas' discours-principe zijn precies die handelingsnomen geldig, waamee alle mogelijke betrokkenen als deelnemers aan rationele discoursen zouden kunnen instem* men. Met handelingsnomen zijn hier zowel in de tijd als sociaal en zakelijk gegeneraliseerde gedragsverwachtingen bedoeld. Het predikaat geldig word in een algemene normatieve zin bedoeld. Daarin wordt nog geen onderscheid gemaakt tussen geldigheid in een betekenis van moraliteit (van morele normen) en legitimiteit (van rechtsnomen). Onder de categorie betrokkenen valt ieder die door te verwachten gevolgen van een door normen geregelde algemene praxis in ziju belangen wordt getroffen. Onder rationele discoursen vergtant Habemas hier iedere poging tot verstandhouding over problematische aanspraken van gelding wan handelingsnormen. On van rationele discoursen te kunnen spreken moeten zulke pogingen plaats hebben onder voorwaarden die wije discussie mogelijk maken. Direct heet het begrip rationeel discours hien betrekking op communicatief bandelen. Indirect heet het ók betrekking op strategische onderhandelingen, voor zover die plats hebben onder communicatief geregelde voorwaarden van een open, eerlijke procedure. Zo blijh ook strategisch handelen communicatief genomeerd.

Het algemeen discours-principe vali uiteen in een moraal-principe en een democratieprincipe. Het moral-principe betreft handelingsmomen die uitsluitend met morele gronden gerechtvaardigd kunnen worden. Het democratie-principe betreft rechtsnormen. Deze kunnen niet allew met morele gronden max daarnaast ook met ethisch-politieke en met pragmatische gronden gerechtvaardigd worden. De aard van de gronden vloeit telkens voort nit de specifieke vaag die aan de orde is. Bij morele vragen moeten de doorslaggevende gronden in principe door ieder anvaard kunnen worden. De mensheid als 
geheel of een publiek van wereldburgers staat hier model voor het rechtvaardigen van regelingen die in het belang van allen zijn. Ethisch-politieke vragen hebben betrekking op "onze" specifieke levensvorm van een concrete politieke gemeenschap die bepaalde tradities en sterke waarden deelt. De doorslaggevende gronden moeten in principe door alle leden van die gemeenschap aanvaard kunnen worden. Pragmatische wragen eisen een rationele afweging tussen concurrerende waarden en tegenstrijdige belangen. De betrokkenen daarbij zijn direct belanghebbende sociale groepen waarmee onderhandeld moet worden om tot compromissen te komen. Voor zover deze compromissen onder faire onderhandelingswoorwaarden tot stand komen moeten ze in beginsel voor alle parijen aanvaardbaar zijn. De doorslaggevende gronden waarop compromissen ten aanzien van pragmatische wragen aanvaard worden behoeven niet, zoals dat bij morele en ethischpolitieke vragen wél het geval is, voor alie partijen dezelfde te zijn. Maatgevend voor deze benadering van alpartijdigheid is de ruimte die betrokkenen zellf krijgen on hun visie op een probleem aan bod te laten komen.

In een vergelijking met zijn discourstheoretische opvatting wan onpartijdigheid bespreekt Habermas de oorspronkelijke positie in Rawls' theorie van het sociale contract." Rawls bouwt in de beschrijving van een fictieve oertoestand een "sluier van onwetendheid" in over eigen en andermans kenmerken, eigenschappen en levensplannen. De bedoeling is dat vrije en gelijke partijen onder deze sluier van onwetendheid tot de keuze van juiste procedurele principes komen. Faire resuitaten moeten gewaarborgd worden door de faire procedure waarin deze resultaten tot stand komen. Doordat het morele oordelen gelijk schakelt met een rationele keuze van principes onder een tekort aan informatie doet Rawls' model volgens Habermas niet helemaal recht aan de geldigheidspretentie van morele oordelen. Datzelfde is volgens hem het geval met een model dat uitgaat van een ideale overname van rollen, zoals dat van Kohlberg. Volgens Habermas beschouwt Kohlberg morele inzichten als een bijzondere vorm van begrijpen. Doordat in Habermas' voorstel morele argumentatie zélf wordt opgevat als adequate procedure voor onpartjidige besluitvorming, telt in zijn voorstel alleen de kraclit van het betere argument.

Ook Van der Burg wijst op tekortkomingen in Rawls' model van onpartijdigheid. Rawls abstraheert sterk van verschillen in belangen, opvattingen en posities van betrokkenen. Daardoor wordt de onpartijdigheid evenals in Baiers model wan de miet partijdige toeschou. wer jngevuld als een abstracte opvatting van buitenstaanders, aldus Van der Burg. ${ }^{7} \mathrm{Hij}$ laat zien dat de constructies van Rawls en Baier bruikbaar zijn om bepaalde factoren in de oordeelsvorming te betrekken, maar onvoldoende recht kunnen doen aan andere factoren die in sommige situaties essentieel zijn. Als een derde belangrijk model van onpartijdigheid noemt Van der Burg de ideale gespreksituatie van Habermas. Hij laat Habermas' model echter rusten. Volgens Van der Burg is dat dermate complex dat het niel goed doenlijk is er in kort bestek op in te gaan. ${ }^{*}$

7 Van der Burg 1991, p. 212 wist in dit verband op feministische theoretici (roung 1986, Benhabib 1987) die de eenzijdigheid wan abstracte en unwersele onpartijdigheidsnoties aan de kaak stellen. 


\section{Hoofdutuk 4}

Als altematief voor abstracte benaderingen van onpartijigheld kiest Van der Burg voor een perspectievenbenadering, een in de praktijk van de toegepaste ethiek gangbare procedurele benadering wan onpartijdigheid. Daarin wordt getracht de concrete deelperspectieven van de voomaamste betrokkenen te analyseren en met elkaar te verzoenen. Omdat deze benadering wolgens Van der Burg nog weing witgewerkt is, pakt hij dat karwei zelf aan." Een onpartijdig gezchtspunt moet in die zin "alpartijdig" ziju dat het aan alle relevante aspecten wan en visies op een probleem recht doet, aldus Van der Burg. ${ }^{10}$ Daamee maakt hij een opstapje naar zin formuleting wan een ideaal moreel gezichtspunt in de vorm vam "het democratisch perspectief". Dit houdt in dat de deelperspectieven wan alle betrokkenen voor elk van een vijfal aspecten van een politick proces gelikelijk worden meegewogen in een morele oordeelsvorming. De vüf aspecten van een politiek proces zijn 1) participatie in de beshitvorming, 2) de gronden waarop de beslissing wordt genomen, 3) de inhoud van de beslisaing, 4) de vraag wie de beslissing noet witvoeren en hoe dat moet gebeuren en 5) do consequenties van do beslissing."

Het democratisch perspectief als procedureel uitgangspunt vult Van der Burg aan met een inhoudelijke norm van gelijke aandacht, zorg en respect voor alle burgers. Hij maakt duidelijk dat het om een ideaal gaat. Omdat de perspectieven wan alle betrokkenen van binnentit meegewogen moeten worden, is geen sterfelijk wezen in staat daaraan te voldoen. Toch is het een zinvol ideaal, omdat het richting kan geven aan pogingen om een moreel, alpartijdig gezichtspunt in te nemen, aldus Van der Burg."

Een vergeliking laat zien dat zowel bij Habermas als bij Van der Burg de invulling van de notie van onpantijdigheid neerkomt op hat geljkelijk rekening houden met alle betrokken belangen en relevante aspecten van een zaak. Habermas drukt dit uit in het procedurele principe dat slechts die nomen aanspraak mogen maken op geldigheid, die de instemming, kunnen krijgen van alle mogelijke betrokkenen als deelnemers aan een praktisch discours. Volgens Van der Burg is niet alleen cen procedurele norm nodig, een invulling van het moreel gezichtspunt van onpartijdigheid, maar ook een inhoudelijke norm. Als inhoudelijke basisnorm beredeneert hij gelijke aandacht, zorg en respect voor alle burgers in alle aspecten van het democratisch proces.

Habermas geeft naar ik meen een trefzekere benadering van het moreel gezichtspunt van onparijdigheid. Met deze trefzekerheid bedoel ik de identificatie ran het onpartijdig oordeel met het vrije morele oordeel dat wortelt in de zedelijkeid wan het alledaagse gesprek. Vanwege de fundering in de noodzakelijke vooronderstellingen van toegankelijkheid, kritiseerbaarheid en oprechtheid wan het open gesprek verdient Habermas" model nar ik meen de vookeur. Modellen als die van Rawls zijn daarbij vergeleken inderdaad

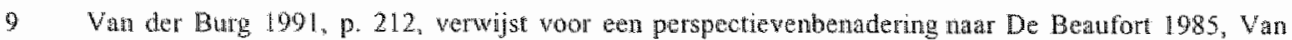
dea Burg 1986, Veddat en Van der Burg 1989, Van de Meent-Nutma 1990.

10 Von der Burg 1991, p. 213.

11 Van der Burg $1991 ., 05$.

12 Van der Burg 1991, p. 213. 
omnodig fictief ${ }^{3}$, terwijl Van der Burg de additionele funderende werking wan Habermas" model lant liggen.

Een voordeel bij Van der Burg lijkt dat hij de deelperspectieven van betrokkenen explioiet op alle aspecten van een politiek proces betrekt. Habermas lijkt zich te beperken tot ratio. nele besluitvorming in engere zin. Aan Habermas' democratie-principe ligt echter een universaliseringsbeginsel ten grondslag. In praktische discoursen neemt dat de vorm van een argumentatieregel aan: bij geldige normen moeten de gevolgen die met het oog op ieders belangen te verwachten zijn bij het algemeen nakomen van deze momen door allen vrijwillig kunnen worden aanwaard. ${ }^{14}$ O betrekt ook Habermas de verschillende aspecten van een politiek proces bij de invulling van de notie van onpartijdigheid.

Aan de reden die Van der Burg opgeeft om het model van Habermas te laten liggen (dat hij het vanwege het complexe wan Habermas" werk niet goed doenlijk vindt om er in kort bestek op in te gaan), valt niet te tomen. ${ }^{5}$ Zijn opmerking dat de in een perspectievenbenadering gezochte procedurele alpartijdigheid in de buurt lijkt te komen van Habermas" ideale gespreksituatie ${ }^{\text {It }}$ wijst er echter op dat hij de verwantschap van zijn benadering met die van Habermas inziet. Wat Habermas' benadering in mijn ogen vóor heeft is, dat in diens democratie-principe expliciet naar voren komt dat betrokkenen in verband met hun eigen positie en belangen in beginsel zéli uitmaker of en hoe ze betrokkenen zijn. Daardoor kan Haberntas" democratie-principe niet monologisch werken. Juist de principieel dialogische aard wan toetsing van nomen stelt Habermas in stat om moreel handelen te verbinden met feitelijk welzijn zonder een beroep te moeten doen op inhouden van normen. Bij Van der Burg is niet uitgesloten dat een modelrechter zoals Dworkins Rechten Hercules in zijn eentje als specialist de (juridische relevantie van de) deelperspectieven van betrokkenen monologisch beredeneert en vervolgens in zijn oordeelsvorming betrekt. ${ }^{\text {in }}$ Een bevestiging wan mijn eerder naief gekozen "alpartijdige" invulling van de notie van onpartijdigheid kan hier metaforisch bezegeld worden met een handreiking van Vrouw Iustitia aan Rechter Hercules. ${ }^{18}$

13 Zie voor een overzicht van de discussie over $\mathbb{R}$ awls' theorie Koen Raes, De post-Rawlsiange rechtwaardigheidsdiscussie, Liberalisme, Egalitarisme; Communtarisme, R\&R 1990, P. 190-210.

14 Mabermas 1991, p. 12.

15 Vgl over de fundering van de theorie wan Van der Burg de recensie van Lack in RM Themis 1992 , p. $291-294$.

16 Van der Burg 1991, p. 212. Als praktische voorbeelden van en perspectiewenbenddering wijst Vun der Burg in dit verband op ethische adviescommissies en toetsingscommissies, waarin gezoclit wordi naar het creëren van een zo apen mogelijke gespreksituatie, zodat de verschillende dedperspectieven tot hun recht kumen komen.

17 Ronald Dworkin, Taking rights serionsly, 1978. Zue ook Habermas 1992, p. 272 c.v. Op de sanenhang tussen Van der Burgs inhoudelijke basisnorm met de theorie van Dworkin ga ik in de volgende paragrafaf nader in.

18 B. wan Roermund, Solidariteit onder wreenden: de rechtstheorie van Jïgen Habermas, R\&R 1994, p. 120-156, p. 137, wijst op het volgens hem uiterst gering werschil tussen en "interstubjectieve interpretatio van Hercules (Habermas) en en therculaanse interpretatie van intersubjectiviteit (Dworkin)" Ook in Habermas' reconstructie van reclit. "zullen de discussiepartners moeten deelnemen vanuit het specilieke juridische perspectief warvour Hercules model stat", aldus Van Roermunc. 


\section{Bruggen tussen private en publieke autonomie}

Gegeven de superioriteit van Habermas' conceptie van democratische alpartijdigheid en de beperkingen ervan voor het begrip van justitiele alpartijdigheid, is er geen andere mogelijkheid dan de koe bij de horens te vatten. Habermas" these van de gelijkoorspronkelijkheld van private en publieke autonomie is door hem zodanig bepaald dat private autonomie zich in het publiekrecht manifesteert in subjectieve vrijheidsrechten. Maar als er werkelijk sprake zou zijn van gelijkoorspronkelijkheld, dan zou ook het ongekeerde moeten gelden. Ook subjectieve privaterechten zouden al en innerlijke betrekking moeten hebben op sociale belangen. Met de vragg hoe deze innerlike betrekking zich vanuit een discourstheorie van het recht laat construeren, heb $\mathrm{Kk}$ lang geworsteld.

Een eerste brug tussen private en publieke autonomie wond ik in kritische beschouwingen van Van Roermund over Habermas' boek Faktiztät und Geltung. ${ }^{19}$ Oppervlakkig gezien zijn deze beschouwingen alleen maar geschikt om mijn twijfel nog verder aan te wakkeren. Maar ze werken ongekeerd. Dat komt denk ik doordat de kritiek draait om wat Van Roermund zelf de mooiste zin van Habermas' boek noemt. ${ }^{20}$ Dat geeft te denken. Waarom vindt Van Roemund deze zin zo mooi?

Voorafgaand aan het citeren van bedoelde zin schrijft Van Roermund dat de door procedures geregelde politiek in het werk vän Habermas vooral een context of justification" constitueert voor de oplossing van matschappelijke problemen. De oplossing zelf van die problemen bliff niet alleen aangewezen op een verdere administratieve "implementatie". Ze blijft ook aangewezen op een "context of discovery" van een niet door procedures geregelde openbaarheid die door het algemene publiek van staatsburgers gedragen wordt. "Enerzijds is die sfeer kwetsbaarder voor systematisch verstoorde communicatievormen (..), anderzijds ontvankelijker voor diversiteit en openheid doordat elke formele regeling ontbreekt; het is de bron van zowel conflicten als nieuwe levensvormen". "I En dan komt de mooie zin:

"Aber" die kommunikative Bewäligung dieser Konflikte bildet in einer säkularisierten Gesellschaft, die mit ihrer Komplexiät auf bewuszte Weise wmztgehen gelernt hat, einzige Qwelle fü eine Solidariät unter Fremden - unter Fremden die auf Gewalt verzichten und die sich, bet der kooperativen Regelung ihres Zusammenlebens, auch das Recht zugestehen, fureinander Fremde zu bleiben. "22

20 Van Roemund 1994, 15. 142.

21 Van Roermund 1994, p. 141-142.

22 Habermas 1992, p. 374; Van Roenmund 1994, p. 142. 
Ekaar het recht gumnen om vreemden voor elkaar te blijven. Met het oog daarop merkt Van Roemund op dat het niet vanzelf spreekt dat Habemas "autonome als een verhouding tussen subjecten wil aflezen aan een subject-object verhouding, waarbinnen het andere subject altijd een derde is, een buitenstaander, een wreomdeling."27 Inderdaad, dat spreekt niet wanzelf. Daarmee raakt Van Roermund ook mijn twijel over het combineren van subjectieve wrijheidsrechten met de idee van private en publieke autonomie. Maar wil Habermas werkelijk autonomie als een wederkerige verhouding tussen subjecten "aflezen" aan een verhouding warbinnen de ander "altijd" een derde "Is? Van Roemund kan best gelijk hebben waar hij oppert "dat Kant de metaforiek van het subjectieve recht gebruikte woor een filosofische redenering inzake wederkerigheid, terwijl deze - overeenkomstig de stelling van Luhmann - in de maatschappelije en dogmatische feitelijkheid van het recht al lang de vorm van een functionele complementariteit had gekregen." Mat kar bat zijn dat "de mooiste zin" van Habermas" boek mooi is, precies ondat or mér in te lezen is dan een functionele complementariteit?

Het gat in die zin on "kommunikative Bewältigung" van maatschappelijke problemen als enige bron van solidariteit onder wreemden die elkaar ókk de vrijheid gumnen on vreemden voor elkar te bljven. Dat lijkt mij een verdienstelijke poging on een verbinding van binmenuit tussen filosofisch opgevatte wederkerigheid en functionele complementariteit tot uitdrukking te brengen. Habermas voorstel tot transfomatie van de klassieke figun van de praktische rede in de communicatieve rede makt cen communicatieve binding wan strategisch gebruik van subjecteve rechten en daarmee een op wederkerigheid gebasearde solidariteit onder vreemden mogelijk. Dat wordt bevestigd door hetgeen eerder in hooldstuk 3 onder openbaarheid besproken is. Bij het in burgerlike openbarheid geleidelijk verbreden en abstracter worden van communicaties kan de onderlinge verstandhouding behouden blijven voor communicaties onder vreemden. Dat deze vreemden elkaar ók de wrijheid gunnen vreemden voor elkaar te bljiven komt overeen met de sociale rumte die binnen een proces van onderlinge verstandhouding ontstat. Precies op die openheid, op die sociale ruimte, is burgerlijke openbaarheid speciaal betrokken.

Anders dan in een pur moreel discours verlangt het juridisch discours geen volledige identificatie van subjecten. Het civiel contract bijvoorbeeld vereist weliswarr wilsovereenstemming, maar dat impliceert niet dat partijen het ook eens moeten ziju over de morete doeleinden die zij met het contract beogen te dienen. Wat dat betreft, kumen partijen gerust wreenden voor elkaar blijwen. Het enige opzicht waarin zij zich met elkaar moeten identificeren is als contractspartien, dat wil zeggen in de wederzidse gebondenheid ara * en verbondenheid van hun contractuele beloften. Op soortgelijke wijze verest het civiele recht "zorgvuldigheid in het matschappelik werkeer". Dit is echter geen morele zorgwuldigheid. Het civiele recht verbiedt geenszins een concurrent op rechmatige wijze tot de bedelstaf te brengen, hoe dubieus dil ook vanuit zuiver moreel oogpunt, zoals dat in preburgerlike tijden prevaleerde, moge zijn. Opgemerkt zij dat het gegeven voorbeeld al iets laat zien wan de innerlike relatie tussen private autonomie en sociaal belang. In de 


\section{Hoofdsite 4}

burgerlike wisie is het belang van het andere individu net onmiddelljk identiek met het algemene belang. Het prevaleren van het belang van de éen ten koste van het belang van de ander kan in het algemeen belang zijn. Daarbij kumen zich echter weer secundaire vragen vootdoen over de wijze warop hel algemene belang zich het geschade individuele belang dient ala te trekken. Bifvoorbeeld, in het geval wan de failliet geconcurreerde ondemener, in de vorm wan een bijstandsuitkering.

Aan de hand wan dit voorbeeld blikt ook hoe de drie dimensies van rationaliteit, de instrumentele, de strategische en de communicatieve rationaliteit ${ }^{25}$ alle drie in het recht een rol spelen, zij het op een ten opzichte van het morele discours gedifferentieerde wijze. Het commerciele contract is voor beide partijen cen instrument, waamee ze eigen belangen dienen, warwan sommige mogelijk van strategische aard kunen zijn, zelfs in de directe relatie tot de wederpartij. Niettemin zal het contract wil het valide $z \mathrm{gn}$, wel aam zekere eisen van communicatiewe bepaaldheid (de essentiële contractsvereisten) moeten voldoen, en zullen partijen bij de uitvoering van het contract ook een zekere mate van zorg dienen te besteden an de belangen wan de ander. Maar er is, anders dan in het morele discours, geen sprake meer van een directe identificatie van partijen, angezien de communicatieve rationaliteit voor zover die betrekking heeft op het basale welzijn van de andere contractspartij, gedifferentieerd is in een afzonderlijk rechtssysteem, namelijk dat van de sociale verzekeringen.

Een tweede brug tussen private en publieke autonomie vond ik bij Riki Holtmaat, waar 2ij pleit voor het overstigen van dichotomieèn in het recht ${ }^{26}$ De eerste dichotomie die in haar ogen moet worden angepakt is de tweedeling tussen recht en behoefte, die overeen komt met niet-verantwoordelijkheid en zorg. In dat verband oppert zij werruiming van het concept van subjectieve rechten. ${ }^{27}$ Naast claims op basis wan prestaties kunnen rechten ook opgevat worden als een wijheid (privilege), ean macht (bevoegdheid) of een immumiteit (onahankelijkheid). Het is dan mogelijk naast verschillende prestaties ook afhankelijkheid, zorg en behoefte ten grondslag te leggen an een recht. Als voorbeeld geeft Holtmaat de tegenstelling tussen een recht op bijstand (op basis van behoefte) en een recht op een sociale verzekeringsuitkering (op basis van prestatie) in het Nederlandse recht. Deze tegenstelling werspigget een tegenstelling tussen een ffecr van zorg en een sfeer van recht. Een recht op bijstand op basis van behoefte zou in de recienering van Holmaat opgevat kumnen worden als cen immuniteits-recht (vrijwaring tegen armoede). Op het niveau wan basale levensbehoeften drukt de behoefte aan bijstand afhankelijkleid uit. Op het niveau van het recht kan een immuniteits-recht arvoor zorgen dat deze afhankelijkeid een fundamentele onathankelikheid niet aantast. bogin van deze eezw onwikkelde. Daarin wordt onderscheid gemaak tussen vier soorten rights die elk cen relatic ussen rechthebbende en omgeving inhouden. Op basis van verschillende prestaties, atributen, situaties of thodarigheden van mensen kunnen al deze soorten subjectieve rechten een juridisch afdwingbare aunspralk opleveren. 
Holtmaat wijst erop dat via discussie "over wat rechten zijn en wellke inhoud we daar aan willen en kunnen geven" binnen het recht plaats gemaakt kan worden voor wat de Nederlandse rechtsfilosoof "t Hart "alteriteit" noemt. ${ }^{28}$ In deze visie moet het recht twee vormen van rechtsbescherming bieden. De ene vorm bestaat in rechtens afdwingbare rechten. De andere vorm van rechtsbescherming ligt in ruimte voor het andere verhaal, dat wil zeggen in een noodzakelijke openheid van het recht voor andere dan de dominante interpretaties van de werkelijkheid. ${ }^{29}$ Deze gedachtengang sterkt mij in mijn poging om het rechtsgehalte van rechtens afdwingbare rechtsnormen (de ene vorm van rechtsbescherming) te baseren op een evenwicht tussen private en publieke autonomie dat intern samenhangt met een "alpartijdige" openbaarheid (de andere vorm van rechtsbescherming). Zo wordt met het oog op rechtsbescherming de onderlinge samenhang tussen dwang en vrijheid in het recht inzichtelijk. De aliernatieve interpretatie van een rechtsnorm of van de feiten die in het geding zijn, zoals die door een partij in het rechtsgeding naar voren worden gebracht, zijn niet slechts uitdrukking van subjectieve procesrechten, maar tegelijkertijd uitingen van publieke autonomie zoals die zich volgens de alpartijdigheidsprincipes van de rechtspraak voltrekt. Op de procedurele kant hiervan behoeven we hier niet in te gaan. Het gaat ons hier om een innerlijke betrekking van rechtsideeën zoals die zich zouden moeten laten afleiden uit het gespreksmodel.

\section{Drie beginselen van rechtens behoorlijk handelen}

Het open gesprek, gekoppeld aan de notie van alpartijdigheid, staat in dit betoog model voor zowel procedureel als inhoudelijk behoorlijk, wederkerige verplichtingen scheppend handelen in een rechtsorde. Het wordt gekenmerkt door communicatieve vrijheid van betrokkenen. Met het oog daarop kan met name de morele dimensie van vrijheid in deze stand van het betoog ${ }^{30}$ naar ik meen zonder verdere toelichting voorgesteld worden als kenmerkend aspect en in die zin als leidend procedureel en inhoudelijk beginsel van rechtens behoorlijk handelen. ${ }^{31}$

Aan erkenning van de morele dimensie van vrijheid als leidend beginsel van rechtens behoorlijk handelen hangt een prijskaartje, zowell in de negatieve als in de positieve betekenis van het woord prijs. Te betaalt een prijs en je krijgt er een. De prijs van vrijheid is trouw..$^{32}$ In tegenstelling tot de bewering over vrijheid behoeft deze bewering over trouw hier wél toelichting. Trouw als prijs van vrijheid zit in een communicatief opgevat

28 Holtmaat 1993, p. 78. A.C. 't Hart, Recht als schild van Perseus, voodtachten over strafrechtstheorie, Arnhem-Antwerpen 1991, p. 53.

29 Deze gedachiengang sluit aan bij Marjed Gunning. Onwolwassen recht, Nemesis 1994, p. 17-23, watar deze pleit voor erkeming wan het kind als de ander if plats van als bijna-volwassene. Het kind zou juist in het anders-zijn dan de volwassene noeten worden gerespecteerd en bevestigd. De juridische annexatic van bet kind sluit niet alan bij de behoeften van het kind maar is volgens Gunning een gevolg van eigenmachtig gelijkheidsdenken van wolwassenen.

30 Zie vooral hfolst. 3 , par. 4, betreffende principieje erkerning van menselijke wrijheid en walardighoid

31 Zie hfdst. 7, par. 3, over beginselen wan behoorlijk handelen in een benadering door Van Gerven. (1983), in samenhang met algemene beginseler wan behoorlijk bestur.

32 Hermann Krings, Systen und Freiheit, Freiburg/Minchen 1980, p. 229.-230. 
vrijheidsbegrip, zoals dat eerder naar voren is gekomen. ${ }^{33}$ De autonome grond van handelen die vrijheid wordt genoend is de basis wan betrouwbaarheid. Deze grond van betrouwbaarheid is het besef van morele vrijheid zélf. Wie moreel vrij is staat in voor beslissingen die zij of hij in vrijheid neemt. Precies in de standvastigheid van dit instaan voor vrijheid houdt wrijheid stand. Dit maakt de idee van een prijs amkeerbaar: de prijs die de trouwe wint is de vrijheid. Morele vrijheid en trow zijn in een handelingsperspectief onverbrekelijk met elkaar verbonden.

Vrijheid draagt onvermijdelijk het risico in zich van het nieuwe, het onvoorziene, het niet onder voorafgaande controle gebrachte. In een wisselwerking tussen vrijheid en trouw word dit risico in vormen van betrouwbaarheid aanvaard. Maar het is een misverstand als trouw hier uitgelegd wordt als consequent vasthouden aan een abstracte vrijheidsgedachte. "Trouw is geen gehoorzaamheid aan eigen ideeën of idealen, maar lotsverbondenheid. werbondenheid met de nog onbekende lotgevallen van wat ons dierbaar is." ${ }^{34}$ Trouw is de kwaliteit wan onderlinge verbondenheid met anderen, als redelijke en zedelijke wezens.

In het open gesprek is trouw niet weg te denken. De aanspraak op geldigheid van uitspraken is synoniem met het te kennen geven van de bereidheid om in te staan voor de waarachtigheid van persoonlijke uitingen en voor het desgewenst aanvoeren van goede gronden voor aanspraken op waarheid van feiten en juistheid van normen. Een kenmerkend coördinatie-effect ontstaat doordat de toehoorder in een gesprek als vanzelfsprekend aanneernt dat de spreker de ingebouwde geldighejdsaanspraken desgewenst kan onderbouwen. Juist daarom worden deze geldigheidsaanspraken veelal als onproblenuatisch aanvaard. De vooronderstelling van het instaan voor aanspraken van geldigheid is het inherent normatief verbindend betrowwbaarheidsaspect van het gesprek. Zo opgevat stel ik trouw voor als tweede beginsel van rechtens behoorlijk handelen.

Als derde beginsel wan rechtens behoorlijk handelen stel ik voor: zorg. Ook zorg kan, evenals trouw, in negatieve en positieve betekenis uitgedrukt worden als een prijs van vrijheid. En ook zorg is in het open, op onderlinge versiandhouding gericht gesprek verankerd. Ook bij zorg heb ik niet een gehechtheid aan een abstracte vrijheid en openheid op het oog, die dienst moeten doen als basis van een consequente toepassing van een stel universalistische beginselen. Evenals trouw is ook zorg hier op te vatten als concrete verbondenheid in morele vrijheid. Waar trouw ziet op lotsverbondenheid als zodanig, ziet zorg op het wábrmaken daarvan in concreet situatiegebonden materiele vormen. Met vrijheid, trouw en zorg acht ik drie algemene beginselen van behoorlijk handelen in een rechisorde in clie zin compleet, dat dit driespan naar ik meen alle moreel relevante aspecten van menselijk samenhandelen omspant.

33 Zie De Wachter 1987, over het socias moment dat in ieder individueel wrijheidsrech besloten ligt.

34 A. Bums/4. de Dijn, De rationaliteit en liaar grenzen, Leuven/Assen 1986, p. 94, bespreken de betekenis wan trouw of loyaliteit in lhet kader wan de complexe wisselwerking tussen zingeving en manipulatie. 
Hoe paki een inhoudelijke vergelijking uit van drie beginselen van rechtens behoorlijk handelen met Habermas' reconstructie van een stelsel van rechten en met Van der Burgs basisnorm? Laten we beginnen bij Habermas. Als de onderlinge samenhang ussen vrijheid, trouw en zorg houdbaar is, dan ligt het voor de hand dat deze beginselen het hele terrein dekken van rechten op 1) private handelingsvrijheid, 2) politieke autonomie, 3) rechtsbescherming, 4) politieke participatie en 5) sociale, technische en ecologische voorzieningen. De reconstructie van dit stelsel gaat immers uit van gelijke subjectieve handelingswrijheid.

Habermas" stelsel van rechten is inderdaad met drie beginselen van rechtens behoorijk handelen te omvatten. Om te beginnen wijst het concept van private en publieke autonomie naar aspecten van vrijheid. Vervolgens is in de eerste, tweede en vierde categorie van het stelsel van rechten het beginsel vrijheid expliciet richtinggevend. De derde categorie expliciteert vooral het beginsel trouw in de vorm van rechtszekerheid. Bij de vijfde categorie komt het beginsel zorg op de voorgrond.

Anders dan Habermas hanteert Van der Burg niet alleen een procedurele maar expliciet ook een inhoudelijke basisnorm. Van der Burgs basisnorm sluit aan bij een formulering van Dworkin over politieke moraal: "I presume that we all accept the following postulates of political morality. Government must treat those whom it governs with concern, that is, as human beings who are capable of suffering and frustration, and with respect, that is, as human beings who are capable of forming and acting on intelligent conceptions of how their lives should be lived. Government must not only treat people with concern and respect, but with equal concern and respect. ${ }^{\text {r.35 }}$

Van der Burg verbreedt het beginsel van "equal concern and respect" van een norm voor de staat tot inhoudelijk uitgangspunt voor een democratische beslissingsprocedure in het algemeen. Een zelfstandige appellerende kracht van deze basisnorm is volgens hem terug te voeren tot het mensbeeld waarnaar de norm verwijst. "Dat mensen kunnen lijden en aan frustratice onderhevig kunnen zijn en dat zij in staat zijn om op basis van een zelf gekozen levensplan te handelen, zijn inderdaad essentiele kenmerken wan de mens, "3ki Het begrip "equal" bij Dworkin correspondeert volgens Van der Burg met de sterke notie dat democratie iets met fundamentele gelijkheid te maken heeft. Als vertaling voor "concern" kiest hij voor "aandacht en zorg"." Deze begrippen corresponderen volgens bem met argymenten voor democratie op grond van belangenbescherming. Het begrip "respect" lenslotte correspondeert met argumenten voor democratic op grond van autonomie. Daarmee voldoet de strekking van de norm van gelijke aandacht, zorg en respect volgens Van der Burg aan de eis dat alle relevante aspecten van de beslissingssiluatie in vanmerking moeten worden genomen om tot een gerechtvaardigd oordeel te komen.

35 Drotkin 1978, p. 272-273. Van der Burg 1991, p. 105

36 Van der Burg 1991, p. 106. Hij wijs erop dat de antropologie van heitelige fundamentelu gelijklieid van de mens her als indirect relevant een achergrondheore bied watad de nomatieve theorio

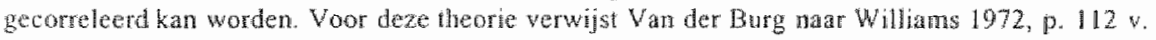

37 Van der Durg 1991, p. 106, verwigh nar The Oxford Paperback Dictionary (1988), we als ex van de betekeissen van liwet werkwoord "concern" geef: "gite carce and attention". 
Van der Burgs veronderstelling is dat de componenten aandacht, zorg en respect alle moreel relevante aspecten van het menselijk leven bestrijken. Mocht dat niet zo zijn, dan kan de formulering van de basisnom aangepast worden om deze gebrekkigheid op te heffen. Daarmee is in de ogen van Van der Burg geen man overboord. ${ }^{3 / 2}$ Gelukkig maar. IK denk dat Van der Burgs basisnom inderdaad aanpassing behoeft om uitdrukking te geven aan alle moreel relevante aspecten van het menselijk leven. De norm van gelijke aandacht, zorg en respect bestrijkt expliciet twee beginselen van behoorlijk handelen. Respect voor autonomie in Van der Burgs basisnorm komt overeen met het beginsel vrijheid. Het beginsel zorg omvat Van der Burgs componenten aandacht en zorg. Als component van zorg betreft gelijkheid van aandacht de gronden voor een beslissing. Gelijkheid van zorg betreft de inhoud van de beslissing. ${ }^{19}$ "Trouw zit niet expliciet in Van der Burgs basisnorm. Ik denk echter aannemelijk te hebben gemaakt dat trouw in een onverbrekelijke samenhang met morele vrijheid en zorg als zelfstandige factor moreel relevant is. Dat komt ook overeen met het beginsel van "integriteit" dat in de achterliggende theorie van Dworkin het politieke ideaal van wrije en gelijke rechtsgenoten weergeef. Met het oog daarop behoeft Van der Burgs basisnorm aanvulling met het aspect trouw.

Met het voorgaande meen ik aannemelijk te hebben gemaakt dat mijn voorstel ten aanzien van drie beginselen van behoorlijk thandelen in een rechtsorde een vergelijking met Habermas' discourstheorie en stelsel van rechten en Van der Burgs op Dworkin geinspireerde basisnorm kan doorstaan.

\section{Drie beginselen van mensenrecht}

Reeds eerder heb ik gewezen op de relatie tussen discursieve rechtvaardigheid en de notie van de rechten van de mens. Ik heb steeds de term "mensenrecht" gebruikt on deze relatie tot uitdrukking te brengen. In deze paragraaf zal ik nader op het aspect van de mensenrechten ingaan.

De besproken drie beginselen wortelen in het alledaagse gesprek. In een model van recht dat op dit gesprek georiënteerd is, zijn deze beginselen te vertalen in algemene beginselen van (het doen van) recht als een specifieke regeling van behoorlijk handelen. Een verdere vertaling in beginselon van mensenrecht is dan te beschouwen als een moreel appèl binnen het recht zelf. Dit appè bestaat in het accentueren van de morele dimensie van vrijheid, trouw en zorg - als universele moreel relevante aspecten van menselijk samenleven - in gevallen waarin rechtsbescherming in de knel dreigt te raken. Dat geldt zowel voor rechtsbescherming in de vorm van afdwingbare mensenrechten als woor rechtsbescherming in de vorm van "het andere verhaal", de noodzakelijke openheid van het recht woor andere dan de dominante interpretaties van de werkelijkheid. 
Het uitgaan van basale, moreel relevante aspecten van samenlewen sluit aan bij een voorstel van Fons Coomans over het opsporen van de kerninhoud van economische, sociale en culturele rechten van de mens." "Hlet begrip kerninhoud betekent dat elk techt een bepaalde intrinsieke waarde in zich draagt die het wezenlijke of het essentiële element wan elk recht afzonderlijk belichaamt. Indien de kerninhoud niet kan worden gewaarborgd verliest een recht zijn betekenis als mensenrecht, omdat in een dergelijk geval de menselijke waardigheid in het gedrang komt die immers het fundament vormt van de rechten van de mens." ${ }^{42}$ In mijn voorstell kunnen de beginselen vrijheid, trouw en zorg in onderlinge samenhang richting geven aan het vaststellen van de kerninhoud van mensenrechten. De typologie van verplichtingen van staten met het oog op de kerninhoud van mensenrechten (verplichtingen "to respect", "to protect" en "to fullfil") ${ }^{43}$ sluit aan bij mijn voorstel tot een méérdimensionaal respect voor vrijheid. ${ }^{44}$

Ik stel voor het mensenrechtelijk beginsel vrijheid te differentiëren naar private en publieke autonomie. In het verlengde daarvan kan dan geprobeerd worden ook de beginselen trouw en zorg naar dimensies in de private en de publieke sfeer te differentiëren. In dit voorstel speelt het openbaarheidsbegrip een dubbelrol. Het speelt niet alleen vanuit een democratisch perspectief een centrale rol met het oog op het uitoefenen van publieke autonomie. Het markeert ook de in openbaarheid in een betekenis van publieke openheid voortdurend te bevestigen of opnieuw vast te stellen grens tussen het private en het publieke (de grens tussen private en publieke autonomie). Het rechtskarakter wan dynamisch opgevatte openbare ordening, als uitoefening van publicke autonomie, wordt bepaald door het evenwichtig gelijktijdig tot gelding brengen van private en publieke autonomie. In het statisch opgevat begrip openbare orde verwijst de component openbaarheid naar het evenwicht zélf, dat als grens tussen het private en het publieke in het dynamisch proces van openbare ordening behouden of opnieuw vastgesteld moet worden. De vraag naar die grens, de vrag maar het evenwicht tussen persoonlijke en gemeenschappelijke aspecten van vrijheid, moet telkens een antwoord krijgen in argumenlaties waarin vrijheid als leidend beginsel van mensenrecht in onderlinge samenhang met de beginselen trouw en zorg richtinggevend is.

Resteert de vraag: waarom niet ók een gelijkheidsbeginsel als beginsel wan mensenrecht? Mijn antwoord is eenvoudig. Gelijkheid is niet een zelfstandige materiële component náast wrijheid, trouw en zorg. Het gat on de oeroude, naar Aristoteles terug te voeren notie van gelijke behandeling in gelijke gevallen en onderscheid naar de mate van relevante verschil. len. Deze notie van gelijkheid werkt dóór het moreel gezichtspunt van allpartijdigheid via

41 A.P.M. Coomans, Schendingen van economische, soctale en culturele rechter, in de Manshrichtse buadel De toenemende betekewis van economische, sociale en culturele mensenrechten, onder redactie wan Coomans/heringa/Westendorp, Leiden 1994, $\mathrm{p}, 59-73$.

42 Coomuns 1994, p. 69 .

43 Coomans $1994, \mathrm{p}, 71 \%$

44 Hoofdsuk 3, par. 4, over het wrigheidsbegrip. 
drie procedurele en materiële beginselen van gelijhwaardige wijheid, troww en zorg. ${ }^{45} \mathrm{lk}$ stel voor met dit instrumentarium van drie beginselen van mensenrecht in het tweede deel wan deze studie naar functies en inhoud van het begrip openbare orde in het Nederlandse recht te kijken. In het afsluitende hoofdstuk zal ik dan het resultaat van deze exercitie bekijken, ook met het oog op alpartijdigheid.

45 Zie G.1. Postema, Equality as membership, R\&R 1990, p. 155-178; G. Maneschijn e.a., Geligherd voor allen - is dat rechivardig?, een publikatie van het Nederlands Gespreks Centrum 1989; Rieneke Meij-van Bruggen, Grondrechten als dilemna van overheidsoptreden, Den Haag 1989, over een Cormeel en en materieel aspect van het begrip gelijklheid; Raes 1991 an de daar opgegeven literatuur over het geljkheids en differentie-denken in de feministische discussie; Wentholt 1991 over het rekening houden met zorgtaken, als een ander perspectief toor het gelikheidsbeginsel. 


\section{DEEL II}

\section{MENSENRECHT EN OPENBARE ORDE IN HET NEDERLANDS RECHT}





\section{INTERNATIONAAL PRIVAATRECHT}

\section{Inleiding}

In het wweede deel van deze studie ga ik ervan uit dat het begrip openbare orde in het Nederlandse recht algemeen inzetbaar is ${ }^{\prime}$ en uitdrukking geef aun de basale mensenrechtelikk georiënteerde waarden en nomen die het Nederlandse recht dragen." Centrale vraag: zijn functies en inhoud van het begrip openbare orde in het Nederlandse recht adequat weer te geven in de optiek van doomwerking van vrijheid, tronw en zorg als drie beginselen van mensenrecht? Ik ga uit van de veronderstelling dat ontwikkelingen op het gebied van mensenrecht in de te onderzoeken rechtsgebieden mede tot uitdrukking komen in de ontwikkeling van het openbare orde begrip in die rechtsgebieden.

Dat ik begin in het Nederlands intenationaal privaatrecht (ipr) heeft te maken met het volgende. In de internatiomale context van dit rechtsgebied ligt een orientatie op mensenrecht voor de hand. Daarbij komt dat het begrip openbare orde in dit rechtsgebied vanouds. een cruciale rol speelt. Daarmee is het interessante van dit rechtsgebied voor deze studie gegeven. IK denk dat met name de functies die het begrip openbare orde in dit rechtsgebied heeft, een aanknopingspunt zijn voor de rest wan dit deel. Bekeken kan worden of deze functies ook in andere rechtsgebieden te vinden zijn en waarop ze inhoudelijk betrekking hebben.

In het ipr gaat het om twee vragen. Van welk land is de rechter bevoegd een zaak waarin internationale elementen een rol spelen te berechten? Stel dat de Nederlandse rechter in een gegeven geval bevoegd is. Welk rechtsstelsel is dan van toopassing? Latcn we een eenvoudig voorbeeld nemen, diclit bij hus, warin het Nederlandse rechtsstelsel van toepassing zou kunnen zijn of dat van een van de buturlanden. Stel dat een in Nederland wonende wrotw bij de Nederlandse rechter een verzoek indient tot echtscheiding of scheiding van tafel en bed tegen har in Belgie wonende man. Man en vrouw hebben de Duitse nationaliteit. Is de Nederlandse rechter bevoegd om over de eis van de vrouw te beslissen? Zo jo, welk rechtsstelsel is van toepassing, het Nederlandse, het Belgische of het Duitse?

Wie probeent enig inzicht te krijgen in het ipr zal op zijn minst op éen punt snel bereid zijn specialisten op dit rechtsgebied gelijk te geven. Het ipr wertoont hot beeld van een

3 Vga HR 23 februari 1973, NJ 1973, 366. Op deze kwestiv kom ik later in dit hoofdstuk terug. 


\section{Hoofdstuk 5}

chaotisch rechtsgebied. Het is een lappendeken ${ }^{4}$ die steeds bonter schijnt te worden. ${ }^{5}$ Op vragen over de bevoegdheid van de rechter en over het toe te passen rechtsstelsel probeert het ipr antwoord te geven in een stelsel wan verwijzingsregels. ${ }^{6}$ De materie is echter kenrelijk te weerbarstig om tot een nationale en internationale beslissingsharmonie te komen. Ondanks velerlei pogingen daartoe is dat door de eeuwen heen zowel op theoretisch niveau als in de rechtspraktijk (nog?) niet gelukt. Wellicht is juist dáárom iets anders wél gelukt.

Het begrip openbare orde is eeuwen geleden in het ipr ten tonele gevoerd en is er tot op de dag van vandaag in geslaagd een inhoudlelijk onduidelijke, maar functioneel effectieve dubbelrol te blijven spelen. Het stelt de rechter in staat om desgewenst het resultaat van bestaande verwijzingsregels te doorkruisen. In de rol van "strijd met de openbare orde" van het land van de rechter (de negatieve werking van de openbare orde) doet het dienst om toepassing van ongewenst (vreemd) recht af te weren. In de rol van "recht van openbare orde" (de positieve werking van de openbare orde) doet her dienst om toepassing van gewenst (eigen) recht dwingend op te leggen.

Om te zien hoe het openbare orde begrip in het ipr is binnengekomen (par. 2), schets ik hierna in vogelvlucht de geschiedenis van het continentaal-Europese ipr. Vervolgens besteed ik vrij uitvoerig aandacht aan een in 1895 verschenen Gronings proefschrift van Ferdinand Kranenburg, getiteld "Eenige opmerkingen over het begrip: "Publieke Orde" (par. 3). Dit proefschrift geeft de stand van zaken weer rond het begrip openbare orde in het Nederlands national en internationaal privaatrecht tegen het einde van de vorige eeuw. Het biedt een zowel inhoudelijk als in de tijd passende start voor een verhaal over openbare orde als algemeen rechtsbegrip in het ipr in de laatste honderd jaar.

De bespreking over de periode 1895-1995 loopt van een verkenning van de transformatie van zedelijke beginselen in rechtsbeginselen (par. 4) via samenhang met voorrangsregels (par. 5) naar beginselen van mensenrecht (par. 6) die mede via het begrip openbare orde doorwerken in het ipr. In het verlengde daarvan bespreek ik de wraag of openbare orde als algemeen rechtsbegrip een ingang biedt voor toetsing van vreemd recht aan het Europees mensenrechtenverdrag (par. 7). In de context van het EEG-Verbintenissenverdrag komt in de laatste paragraaf van dit hoofdstuk het openbare orde begrip naar voren als laatste kwaliteitstoets in het ipr (par. 8).

Th. M. de Boer, De vermaalschappelijking wan het intemationaal grivatrecht, NJB 1980 , p. $785-796$, zis p. 796 .

6 Zie voor cen samenvatting van de bestaansreden wan het ijg J.G. Sauveplanne, Elementair Intemationaal Privaatrecht, negende druk, Deventer 1989, p. 16 v. Zie ook Asser-Scholten. Algemeen deel, 1974, p. $146 \%$ 


\section{Opkomst wan het openbare orde begrip im het ipr}

Vragen naar de bevoegdheid van de nationale rechter in een international geval eir mar het toepasselijke rechtsstelsel worden actueel als intemationaal rechtsverkeer geconfronteerd wordt met een grote verscheidenheid in rechtsstelsels. Deze situatie ontstat in het middeleeuwse Noord-Italië. Daar begint dan ook de geschiedenis van het continentaalEuropese ipr. ${ }^{7}$ Evenals in Noord-Italië komt in de loop van de tijd ook in andere landen een stelsel van verwijzingsregels tot ontwikkeling, de zogenaande statutenleer. Aan de hand van de aard en strekking van bestaande rechtsregels (statuten) wordt het toepassingsgebied van deze regels bepaald. Sommige regels volgen een persoon als hij naar een wreende staat gaat. Deze staat dient dan bij een desbetreffend conflict vreend recht toe to passen. Andere regels werken uitsluitend op het grondgebicd van de eigen staat, naar verbinden dan ook een ieder die zich op dat grondgebied bevindt.

In de negentiende eeuw heeft een omwenteling plaats in het ipr waaraan de naam van de Duitse rechtsgeleerde Von Savigny (1779-1861) verbonden blift. Von Savigny gat niet uit wan de aard en strekking van de rechtsregel, zoals de statutenleer. Hij gaat uit van de rechtsverhouding tussen conflicterende partijen. Een feitelijk aspect aan deze verhouding dient als aanknopingsfactor woor het aanwijzen van het rechisstelsel dat het nauwst bij de rechtswerhouding betrokken is.

In aansluiting bij Von Savigny's orientering ontstat onder leiding van de Italiaanse rechtsgeleerde en staatsman Mancini (1819-1888) de Romaanse of Italiaanse school. Het beginsel van gelijkheid van staten dwingt er volgens hem toe om op bepaalde rechtsgebieden, zoals het personen-, familie- on erfrecht, het nationaal recht van burgers toe te passen, ongeacht waar deze zich bevinden. Het is dwingend toepasselijk recht van "ordre prive". Op andere terreinen van "ordre prive", zoals op dat van het contractenrecht, is het toepasselijk recht niet van dwingende aard. Daar geldt het beginsel van partijautonomie. Dit houdt in dat aan partijen zelf de keuze wordt gelaten ten aanzien van het toe te passen rechtsstelsel. Staten zijn rechtens verplicht deze keuze van partijen te eerbiedigen.

Het beginsel van gelikheid van staten bij Mancimi kan gezien worden als afgeleid van zijn uitgangspunt: "de wrije mens als drager van cultunr, met zijn cigen taal, godsdienst cn ook recht." In deze interpretatie rypeent de nationaliteit van een persoon een sfeer van culturele wrijheid war vreende staten af moeten blijven." Dat de vrijheid van de persoon uitgangspunt is, past ook in Mancini's visie op partiautonomie in het overeen-

7 L. Strikwerda, Inleiding to het Nederlands International Privaatrech, vijfde druk, Groningen 1997. Zie p. $32 \gamma_{\text {. }}$ met literaturoverzicht.

8 Strikwerda 1997 , p. 39. Vgl. Roeland Duco Kollewijn, Het beginsel der openbare orde in hei intemationat privatrecht, "S-Gravenhage, 1917 , p. 37 .

9 IH.A. van Loon, De wisselwerking tussen international privatrecht on rechten van de mens, in Grensoverschrijdend privatrecht Deventer 1993, p. 139. Anders: Strikwerda 1997, p. 39-40, die de nadnuk legt op het eenheidsstreven van Mancini als staatsman.

10 Voor en rechtsvergelijkente studie over mationahteisrecht zie Gerard-René de Groot, Staatsange. horigkeil im Wandel, 's-Gravenhage 1988. 


\section{Hoofdsiuk 5}

culturele wrijheid waar vreemde staten af moeten blijven." Dat de vrijheid van de persoon uitgangspunt is, past ook in Mancini's visie op partijautonomie in het overeenkomstenrecht. In een tegenstelling tot regeils van "ordre prive" komt in Mancini"s leer het begrip "ordre public" in het ipr tot ontwikkeling Op het grondgrebied van de regelgevende staat zijn regels die strekken tot bescherming van hel algemeen belang en van de goede zeden van "ordre public". Deze regels verbinden een ieder die zich op dat grondgebied bevindt. Daarbuiten hebben ze geen werking.

Mancini probeert een scherp onderscheid te maken tussen een op menselijke vrijheid gericht universeel werkend recht van "ordre prive" en een op algemeen belang gericht, slechts in eigen Jand werkend recht wan "ordre public". Zonder acht te slaan op de inlhoud van het recht wan een bepaalde staat wordt uit de specifieke aard van een rechisinstituut, zoals huwelijk, kiesrecht, eigendom, afgeleid of het van private of van publieke orde is. Dat is theoretisch en praktisch onhoudbaar. Wat te doen als de rechter de toepassing wan vreemd recht van ordre privé onaanvaardbaar acht vanwege de inhoud van dat recht? Hier biedt het openbare orde begrip uitkomst. In een afwerende functie gaat het dienst doen om ongewenst wreemd recht van private orde als in strijd met de openbare orde in het land van de rechter buiten toepassing te laten. In plats daarwan wordt het eigen privaatrecht toegepast als recht "van openbare orde". Hier tekent zich - in de optiek van deze studie bimen het ipr het probleem af van het met gelijk gewicht tot gelding brengen van private en publieke autonomie.

\section{3. "Eenige opmerkingen..." uit 1895}

Kranenburg (1895) onderzoekt het begrip openbare orde zowel in het privaatrecht als in het ipr. " Volgens hem heeft het in beide rechtsgebieden dezelfde werking en ook dezelfde soort inhoud. Als een algemene basis voor wat hij "het beginsel van de openbare orde" noemt, bespreekt Kranenburg artikel 14 van de Wet Algemene Bepalingen van het Koninkrijk wan 1829 (Wet $\mathrm{AB}$ ). ${ }^{12}$ Volgens artikel 14 Wet $\mathrm{AB}$ kunnen geen handelingen of overeenkomsten ann de wetten die op de openbare orde en de goede zeden betrekking hebben, haar kracht ontnemen. Evenals het corresponderende artikel 6 van de Franse Code Napoléon beoogt artikel 14 Wet $A B$ een algemeen beginsel over nietigheid van private handelingen uit te drukken. Daarmee is de afwerende functie van wetten van openbare orde en goede zeden duidelijk. Handelingen die in strijd zijn met wetten die de openbare orde of de goele zeden betreffen, zijn rechtens nietig. Op de vrag welke wetten dat zijn of hoe zulke wetten herkenbaar zinn geven artikel 14 Wet AB en artikel 6 Code Napoléon geen uitsluitsel. ${ }^{13}$

10 Voor een rechtswergehikende studie over nationaliteitsrecht zie Gerard-René de Groot, staatsangelörigkeit in Wandel, 's-Gravenhage 1988 .

I1 Ferdinand Kmenburg, Eenige opmerkingen over hel begrip: "Publieke Orde", proefschrif, Gromingen 1895. De begrippen publieke orde en openbae orde zijn bij Kranenburg synoniem.

12 Arikel 14 Wet $A B$ is inmiddells vervallen.

13 Kranenburg 1895, p. 31. Vgl, Asser-Scholten 1974, p. 23 
De afwerende functie van het openbare orde begrip vind Kranenburg ook terug in artikel 1373 ond BW, dat hij gebruikt als opstapje voor het bespreken van dezelfde functie van openbare orde in het ipr. Bij het ontstaan van het Burgerlijk Wetboek (1838) vreesde de Nederlandse wetgever volgens Kranenburg voor misbruik van private vrijheid van handelen. Met het oog daarop bepaalt artikel $1373 \mathrm{BW}$ dat een overeenkomst nietig is als het doel dat partijen ermee beogen bij de wet verboden is of in strijd is met de goede zeden of de openbare orde. Deze "guillotine voor suspecte contracten" 14 , deze "slagboom" van de openbare orde en de goede zeden is ook bruikbaar gemaakt in het ipr, als afweermiddel tegen "gevaarlijke gasten". De gevaarlijke gasten zijn vreende rechtsregels die de Nederlandse openbare orde en goede zeden in gevaar kumnen brengen.

Kranenburg beperkt zijn onderzoek tot wetten van openbare orde. Hoewel artikel 1373 BW apenbare orde en goede zeden noemt als categorieën naast de wet, kan Kranenburg eisen van openbare orde buiten de wet om niet aanvaarden. Op dat onderdeel acht hij artikel 1373 BW overbodig. Eisen van goede zeden buiten de wet om erkent hij wél. De daaruit voortvloeiende problematiek gaat hij echter op een onthutsende manier uil de weg. Hij deelt de lezer eenvoudig mee dat hij het volgens hem "gladde terrein" van de goede zeden niet wenst te betreden. "Het begrip van de openbare orde na te sporen schijnt reeds troosteloos genoeg."

Het privaatrechtelijk artikel $1373 \mathrm{BW}$ geeft welswaar zicht op een parallelle afwerende functie van het openbare orde begrip in het $\mathrm{ipr}$, mar ten aanzien van de inhoud van het begrip levert het Kranenburg niets op. Hij gaat dan te rade bij de publiekrechtelijke Wet Vereniging en Vergadering. Deze wet is een uitwerking van artikel 10 van de Nederlandse Grondwet van 1848, dat luidt: "Het regt der ingezetenen tot vereeniging en vergadering wordt erkend. De wet regelt en beperkt de uitoefening van dat regt in het belang der openbare orde". "Artikel 2 van de Wet Vereniging en Vergadering verbiedt verenigingen die strijdig zijn met de openbare orde. In artikel 3 wordt strijdig met de openbare orde geacht elke vereniging die tot doel heeft: 1 . ongehoorzaamheid aan of overtreding van de wet of een wettelijke verordening; 2 . aanranding of bederf der goede zeden; 3. stoornis in de uitoefening der rechten van wie het ook ziy.

In de Memorie van Toelichting worden deze criteria in positieve zin uitgelegd als eerbiediging van de wet, de goede zeden en de rechten van wie het ook zij. Deze gedachtengang van de wetgever ter nadere bepaling wan het begrip openbare orde moet wolgens Kranenburg worden vastgehouden. Hij vat deze samen in de formules "ongestoorde heerschappij wan het rech" en "deugdelijke rechtsverwezenijking." Als ik het goed zie smokkelt Kranenburg via deze zeer algemene formules de goede zeden (die hij niet in zijn onderzoek wenst te betrekken) het openbare orde begrip binnen. De goede zeden zijn immers

I4 Kranenburg 1895, p. 2.

15 Kranenburg 1895, p. $23-24$.

16 Kranenburg 1895, p. 34 . Een uigebreide analyse is te vinden bij 3.A.O. Eskes, Repressie wan politieke bewegingen in Nederland, een juridisch-lisistorische studie ower het Nederlandse publickrechteligke verenigingsrecht gedurende het tjodvak $1798-1988$. Zwolle 1988, p. $21 \%$ 


\section{Hoofdsuk 5}

onderdeel van de gedachtengang van de wetgever, zoals werwoord in artikel 3 Wet Vereniging en Vergadering.

Terwijl Kranenburg, smokkellend net de goede zeden, de inhoud wan het openbare orde begrip in zeer rume formules samenvat, pleit hij tegelijkertijd voor een beperkte reikwijdte van dit begrip. Verreweg het grootste deel van het recht karakteriseert hij als "utilitair", weîl dwingend recht maar géén recht "wan openbare orde". Openbare orde betreft volgens hem als onderdeel van dwingend recht slechts de wetten die de wetgever absoluut onmisbaar en essentieel acht voor een deugdelijke rechtswerwezenlijking. Van een regel van utilitair recht kan volgens Kranenburg wel de kern, het beginsel, van openbare orde zjin. Voor het overige is het dan een kwestie van de meest geschikte uitwerking.

Kranenburgs pleidooi voor een beperkte reikwijdte van het begrip openbare orde wordt ingegeven door zijn verzet tegen gebruik van het begrip openbare orde in een cirkelredenering. Hij heef geen principieel bezwaar tegen een rume opvatting van openbare orde, als synomiem voor dwingend recht. Waar het hem on gaat is, dat openbare orde niet gebruikt mag worden als synoniem voor dwingend recht en tegelijk als motief om "den wil der individuen buiten te sluiten." $\mathrm{Hij}$ verzet zich, terecht, tegen een quasi-redenering warin de werkelijke reden om een regel op te leggen verborgen blijft. Zo'n redenering kont hierop neer: een rechtsregel is van openbare orde ondat ze dwingend recht is en ze is dwingend recht ondat ze van openbare orde is. In de opvatting van Kranenburg heeft het openbare orde begrip een kerninhoud waaraan rechtens niet voorbij mag worden gegaan. Dat de uitwerking van deze kernimhoud varieert, komt door rechtsverscheidenheid die terug te voeren is tot economische, culturele en andere verschillen.

Voor het opsporen van wetten wan openbare orde in de rechtsstaat Nederland wijst Kranenburg primair op het vrijheidsbeginsel. De openbare orde bestaat volgens hem hierin, dat het recht worde gehandhaafd, "als organisatie der maatschappij en van haar krachten in dien zin, dat aller vrijheid worde beperkt met dit doel en ook slechts in zover, dat ieder zich in zijn sfeer zoo wrij mogelijk zall kumnen bewegen." Hij ziet de persoonlijke vrijheid wan de mens als "misschien het meest tekenende kenmerk van onze matschappij (...) juist een van die beginselen, die de wetgever in zijne matschappij aantreft als een onafwijsbare eisch der volksconscientie; wanneer hij dien eisch niet vervult, dan is van geene rechtsverwezenlijking sprake."20 Daamee komt in Kranenburgs studic gelikwaardige whilheid van ieder nat woren als leidend beginsel van het Nederlandse recht. geworteld in de kem van het begnip openbare orde.

Ook het beginsel zorg komt bij Kranenburg in de kern van het openbare orde begrip naar voren. Dat is het geval war hij beschermingswetten noemt als voorbeeld van utilitair recht mat een kern van openbare orde. Als voorbeeld noemt hij bescheming van minderjarigen. De leenjid warop de meerderjarigheid ingat is veranderlijk en wordt door redenen van 
nuttigheid bepaald. In zijn tijd is die leeftijd in Nederland drieënwintig jaar. Maar het principe zelf van bescherming van de zwakkeren in de samenleving is in de visie van Kranenburg essentieel voor deugdelijke rechisverwezenlijking en dáárom van openbare orde. In dit beschermingsprincipe heeft zorg niet een technische betekenis van zorg voor het in stand houden van een bepaalde juridische ordening. Het morele aspect dat hier in de kern van het openbare orde begrip gesitueerd wordt komt overeen met zorg als beginsel van mensenrecht.

Een mensenrechtelijk georiënteerd beginsel trow in materiële zin is bij Kranenburg niet direct te traceren. Wél procedurele betrouwbaarheid, als de rechtszekerheid van het strikt vasthouden aan de wet. In de geest van zijn tijd staat Kranenburgs visie nog in het teken van de opvatting: geen recht buiten de wet. Het aammemen van eisen van openbare orde buiten de wet om is voor hem niet aan de orde. Eisen van goede zeden buiten de wet om gat hij categorisch uit de weg. Vanuit mijn optiek had Kranenburg de kern van de goede zeden mooi kunnen opvangen als zedelijke beginselen die in zijn aan de wet georiënteerde opvatting van openbare orde (met goede zeden als schaduwbegrip) wortelen. Maar mijn optiek is er een van 1998, niet van 1895, en bovendien loop ik op de bespreking vooruit. Zedelijke beginselen komen in de volgende paragraf aan de orde.

\section{Na 1895: via zedelijke en algemene rechtsbeginselen...}

Volgens Kollewijn (1917) schijnt zich in het ipr een begrip openbare orde te hebben uitgekristalliseerd, "dat in zich de territoriale gelding van "les lois de police et de sûretê" van artikel 3 der Code Napoléon met de omvang van "I"ordre public" van artikel 6 verenigde." ${ }^{\prime \prime}$ Ten aanzien van artikel 6 Code Napoléon komt Kollewijn's benadering overeen met die van Kranenburg. Het gaat dan over openbare orde met goede zeden als schaduwbegrip. Ten aanzien van het politiebegrip openbare orde en veiligheid van artikel 3 Code Napoléon gaan de visies van de beide auteurs uit elkaar. Waar Kranenburg denkt dat het politiebegrip openbare orde (en veiligheid) geheel afgescheiden kan worden gehouden van het privaatrechtelijk begrip openbare orde (en goede zeden), legt Kollewijn via het geldingsbereik van het politiebegrip een verbinding tussen de beide begrippen. Dir wijst eens te meer op algemene inzetbaarheid van het openbare orde begrip.

Na een onderzoek dat hij ook uitstrekt tot het Anglo-Amerikaanse recht kont Kollewijn tot de conclusie dat een begrip openbare orde bij de meest verschillende schrijvers te vinden is en in vonnissen van rechters van verschillende staten fungeen. Hij bedoell "de openbare orde, die zekere zedeliksheidsbegrippen omvat, welke geach worden aan de ganse beschaafde wereld gemeen te zijn." ${ }^{\text {"22 }}$ Als toepassing van wreemd recht geweigerd

21. Kollewijn 1917, p. 18 . Om de tijd te traceren warin de term "openbare orde" in het ipr in de literatuur verschignt, gaat Kollewijn terug tot een uigave van Valette wan Proudhon"s Traté sur l'étal des personnes (1848). Zie hierover onk J. Warda, Nederlands internationaal personen- en familierech en de openbare orde, in: "T Exempel dwinght, Kisch-bundel, 2wolle 1975, ,3. 389-408, p. 397-398, olice de tem openbare orde terugvoert to Jean Domat (1625-1696). "Tratte des loix". Paris 1689. Kollewijn 1917 , p. 54. 


\section{Hoofdstuk 5}

wordt, dan wordt volgens hem echter ten onrechte aangenomen dat geweigerd wordt ondat de gehele beschaafde wereld dat vreende recht als onzedelijk verwerpt. In zijn ogen vindt de rechter de maatstaf "in de rechts- en zedelikheidsopvattingen, welke in zijn eigen staat heersen - en nergens anders. ${ }^{223}$ Hij komt tot de conclusie dat het niet mogelijk is het recht van openbare orde te bepalen. Kennelijk ziet hij in "zekere zedelikhidsbegrippen", ook al lijkt "de gansche beschaaffe wereld" ze min of meer gemeen te hebben, geen houvast voor de rechter bij het hanteren van het begrip openbare orde. "Het beginsel der openbare orde geeft aan de rechter geen richtsnoer, geen middel om te vinden wat recht is."24

In tegenstelling tot Kollewijn ziet Hijmans (1937) wél iets als een richtsnoer voor de rechter. ${ }^{25}$ Hij zet de openbare orde in de traditie van rechterlijke rechtsontwikkeling wia beginselen. Hij vergelijkt het taaie leven van de openbare orde in het ipr met de Romeinse bona fides, de latere goede trouw. Met behulp daarvan heeft de rechtspraak het contractenrecht in vele richtingen op woortreffelijke wijze uitgebouwd, aldus Hijmans. Hetzelfde gebeurt volgens hem in het ipr "achter het rookscherm der openbare orde, in vele landen, niet altijd op dezelfde wijze, maar toch overal met veel succes."26

In hun opvattingen over wettelijke rugdekking voor openbare orde staan Kranenburg (1895) en Hijmans (1937) pal tegenover elkaar. Waar Kranenburg vasthoudt aan wetten wan openbare orde betoogt Hijmans dat rechtsbegrippen als openbare orde zich in wetten niet goed thuis voelen. "Men bespare aan de openbare orde pijnbank en levenslang tuchthuis. Zij blijve buiten de wet." ${ }^{327}$ In het werk van Hijmans wordt een ontwikkeling van zedelijke beginselen in het recht in de richting van algemene rechtsbeginselen zichtbaar. Van Brakel (1953) traceert deze ontwikkeling aan de hand van uitspraken van ce Hoge Raad. ${ }^{28}$ Als hij toepassing van vreemd recht in strijd acht met zedelijke beginselen dan levert dat volgens de Hoge Raad een resultaat op "dat naar Nederlandse opvatting niet mag worden geduld" of dat "de Nederlandse rechtsorde niet toelaat" of dat in strijd is met "de grondslagen van de Nederlandse rechtsorde."29 Deze ontwikkeling van zedelijke beginselen in de richting van beginselen van recht komt overeen met een in het eerste deel van cleze studie besproken vertaling van beginselen van rechtens behoorlijk handelen in algemene rechtsbeginselen.

23 Kollewijn 1917, p. 56 mat verwijgingen.

24 Kollewijn 1917, p. 134.

25 I.H. Hijmans, Algemeene Problemen wan Internationaal Privaatrecht, Zwolle 1937

26 Himans 1937, p. 236. Vgl. J.M.M. Eras, De overeenkomst in het international priwatrecht, "s-Graven. hage 1928.

27 Hijuatus 1937, p. 237 .

28 S. van Brakel, Grondslagen en Beginselen wan Nederlands Intermationaal. Privantecht, derde druk. Zwolle 1953, p. 98.

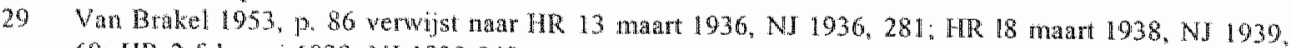
69: HR 2 februari 1939, NI 1939848. 


\section{5. en in samemhang met voorrangsregels...}

De samenhang wan het leerstuk wan de openbare orde en de leer van de voorrangsregels in het ipr is als volgt te traceren. ${ }^{30}$ In de traditie van hel ipr sedert Von Savigny valt het publiekrecht buten de werking van de verwijzingsregels. Met het steeds neer vervagen van de grens tussen privaatrecht en publiekrecht, zeker met de opkomst wan de verzorgingsstaal, ontstaat cen steeds groter tussengebied. De vraag is dan hoe dit senu-publiekrech in het jpr valt in te passen.

Aanhangers van de Romaanse leer beschouwen het semi-publiekrecht als recht "van openbare orde"." Het onttrek zich in deze visie an de verwijzingsregels in het ipr en verbindt als dwingend recht een ieder die zich op het grondgebied van de wetgevende staat bevindt. Het kan slechts door de rechter van deze staat worden toegepast. Als te ongenuanceerd blijkt deze leer in de praktijk onhoudbaar. In een volgende leer dient het als toepasselijk aangewezen rechtsstelsel integraal te worden toegepast. Niet alleen het privaatrecht, maar ook het semi-publiekrecht wordt dan geacht onder de verwijzingsregels te vallen. Ook deze leer blikt praktisch niet te werken. Ze wordt werdrongen door de bijzondere aanknopingsleer. Daarin is het leerstuk van de voorrangsregels ingebed. ${ }^{32}$

In de bijzondere aanknopingsleer worden semi-publiekrechtelijke regels - als mogelijke voorrangsregels - op hun toepasselijkheid in internationale gevallen beoordeeld. Daarbij spelen de functie en inhoud van deze regels een belangrijke rol. Het Alnati-arrest van de Hoge Raad uit 1966 staat bekend als de uitspraak waarin de Hoge Raad de bijzondere aanknopingsleer heeft aanwaard. ${ }^{33}$ De Hoge Raad aanvaard de mogelijkheid dat niet alleen eigen maar ook buitenlands ordeningsrecht voor toepassing als voonangsiegel in aanmerking komt. ${ }^{34}$

Door de opmars van de voorrangsregels krimpt het terrein van de openbare orde. Wordt daardoor de stelling over het algemeen inzetbare van het openbare orde begrip ondergraven? Mij lijkt van niet. Gelet op hun ontwikkelingsgang knnnen voorrangsregels juist gezien worden als regels van openbare orde in de rume betekenis van synoniem voor dwingend recht. Maar ook in een enge opvatting wan het openbare orde begrip blijt cen

30 Strikmerda 1997, p. 88 e.v.

31 P. Vlas, Internationaal privatrecht in de spiegel wan het nieuwe BW, rede WU Amsterdam, Devernter 1989, beselmijft het leerstuk van de "positieve openbare orde" als historische voorloper van dat van de voorrangregels.

32 Strikwerda 1997, p. 91 e.w; Vlas 1989, p. 8.

33 HR 13 mei 1966, NJ 1967,3, m.n. HB. Als voorbode van toepassing wan de bijzondere aanknopings leer in de Nederlandse jurisprudentie word gezien de uitspraak. HR 5 jun 1953, N.1953, 613 in de zaak Melchers. Vgl. Strikwerda 1997, p. 91 en Vlas 1989, p. 8. Zie ook Marice V. Polak, Internationaal privaltrecht voor hel forum van de Hoge Raad, Deventer $1990, \mathrm{p} .19$.

34 Zie over het belang van voorangsregels ook L. Strikwerda, Ver ipr-dissertaties, NIB 1988, p. 1444. 1448. Voor voorbeelden van het doordringen van voorangsregels tot privatrechtelijke bepalingen zie Vlas 1989, p. 9-10. 


\section{Hoofdstuk 5}

kern van openbare orde in voorrangsregels behouden. Ik denk hier aan het betoog van Kranenburg, die in 1895 een "beginsel" van openbare orde in overigens "utritair" recht" verdedigt. Als we deze visie vergelijken met voorangsregels, lijk Kranemburgs pleidooi voor een enge opvatting van he "beginsel" van openbare orde met de opkomst van yoorrangsregels gehonoreerd. Deze vergelijking correspondeent ook aardig met de wisie van Verheul $(1973)^{35}$, die voorrangsregels, ook wel règles d'application immediate of Eingrifsnormen genoemd, ziet als situatiegebonden uitwerkingen van universele beginselen.

Het lijkt niet te gewaagd de wolgende samemhang aan te nemen. Het "beginsel" van openbare orde in voor het overige utilitair recht bij Kranenburg (1895) en uitwerking van universele beginselen in woortangsregels bij Verheul (1973), passen in een ontwikkelingslijn waarin in een kertachtig opgevat openbare orde begrip de doorwerking van beginselen van mensenrecht in het ipr steeds duidelijker zichtbar wordt.

\section{6. naar doorwerking van drie beginselen van mensenrecht}

Als cen specifieke samenlevingskring die uitgerust is met een national geweldsmonopolie krijgt de staat in het ipr te maken met levenskringen die een internationaal element vertonen. In dit verband bespreekt Verheul een algemeen beginsel van materiële competentie. ${ }^{36}$ Hy spreekt aver structurele vervlechtingen van samenlevingskringen, zoals de staat, het gezin, het bedrijf, de vereniging, de kerk. Uit een juridische gezichtshoek kan elk van deze samenlevingskringen gezien worden als een zelfstandige materiele competentiesfeer. Mij lijkt dat dit een geslaagde voorstelling is van het beginsel wrijheid, uitgedrukt in mensenrechtelijk georiënteerde vormen van private en publieke autonomie.

In zijn voorstelling van materiële competentiesferen omschrijft Verheul als cen eerste overheidstaak "het lenen van de sterke am" waar die nodig is om nakoming van in andere kringen gevornd recht af te dwingen. Als voorbeeld dararvan kiest hij het overeenkomstenrechi. In de materiële competentiesfeer van de contractanten wordt het recht primair gevormd door contractanten zelf. Het ontleent zijn bindendheid niet aan de wet. Als rechtsinstitut is het contract ook ouder dan de staat en in het volkenrecht wordt het nog steeds als bindend aanvard, los wan enig daaboven stand overheidsgezag. De vaag naar de grenzen an de contractswijheid vertalt Verheul in de vaag nar de grenzen aan de aldwingbatheid in rechte wan datgene wat partijen zijn overeengekomen. Het openbare orde begrip doet hier in zijn afwerende functie (de "slagboon" wan Kranenburg) dienst als grensbopaling.

Openbare orde word hicr gebrukt in een betekenis die ongeveer overeenkomt met "goede zeden", oen "gerewhigheidsmaatstaf die de stat aaniegt, alvorens zin fiat te geven aan

35 J.P. Werhenl, Rechtswinding in the international privatrecht, in Viftig jaar calvinistische juristenvereniging (1923-1973), p. 83-152, p. 121 v.

36 verheal 1973, p. $85 \mathrm{v}$.

37 Verheul 1973, p. 110 , noemt verder als grenzen uniform dwingend recht en voorrangsregels. 
buten zijn loedoen gevormd recht." Van deze "gerechtigheidsmaatstaf" noent Verheul drie varianten. In de eerste plaats zijn ex regels die alleen intern van openbare orde zijn. Dat is national dwingend recht. In de tweede plaats is er de "Nederlandse interivationale openbare orde". Daarmee zijn de zedelijke grondslagen van de Nederlandse samenleving bedoeld. Deze worden in het ipr "internationaal" genoend, ondat ze ook in een internationaal geval geeerbiedigd dienen te worden. Als derde openbare orde variant noemt Verheul een internationaal openbare orde begrip dat niet afhankelijk is van national recht en dat bijvoorbeeld gehanteerd kan worden door een internationale rechter.

De genoende drie varianten van openbare orde zouden volgens Verhenl eigenlijk identiek moeten zijn, in een orientatie op de mensenrechten. "De openbare orde in deze zin is naw verbonden met de idee van wriheid en gelijkheid. van alle individuen, met de mensenrechten." Waar de mensenrechten universeel zijn, moet volgens Verheul de door de staal aangelegde maatstaf dezelfde zijn, ongeacht of de rechten warvan nakoming wordt gevrazgd in een nationale dan wel in een intemationale rechtskring zijn ontstaan. Door historisch gegtoeide bijzonderheden per land is het volgens hem echter algemeen aanvard dat een rechtsregel, die intern dwingend recht is, dit op internationaal niweau niet hoeft to zijint.

De verhouding tussen de genoemde openbare orde varianten typeent Verheul als dubbelzinnig. Duidelijk is wel dat het in de derde wariant gat om en intemationaal wenselijke slandaard. Daarbij wordt zo nodig niet alleen afstand genomen van afwijkende opvattingen in andere landen maar ook van nationale opvattingen. Het ontsluiten van hef recht in de richting wan de (juridische) moraal is een dynamisch proces. Dit proces kan op een bepaald punt in het ene land verder gevorderd zijn dan in het andere. In zijn Leidse oratie in 1978 zegt Verheul: "Het toetsen van een vreemd recht aan onze eigen rechisbeginselen, het vergelijken van vreemde rechtsinstellingen met de onze, scherpt de blik en makt kritisch ook tegenover het eigen recht. De openbare orde kan dan een tweesnijdend zward worden dat zich niet alleen naar buiten maxir ook naar binnen keert. ${ }^{\text {wil }}$

Een opleggende functie heeft het openbare onde begrip in de ogen van Verhenl bij een categorie statstaken die hij typeert als het sanctioneren van een door de meerderheid in een bepaalde kring gewenste regeling die in het algemeen belang is en lie niet zonder staatshulp kan worden gerealiseerd. Als voorbeeld noemt hij de op het Cognossementsverdrag van 1924 gebaseerde Hague Rules. Dat zijn standaardvoorwarden van particuliere herkomst. Het openbare orde begrip dient hier het algemeen verbindend maken van teze standaardwoorwaarden.

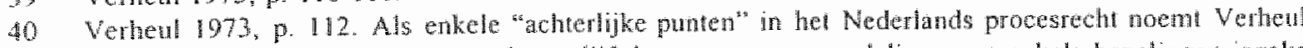
gratis-admissie, betekening ten parkette, lifsdwang tegen reemdelingen en enkele bepalingen imzake die recherligke bevoegdlut.

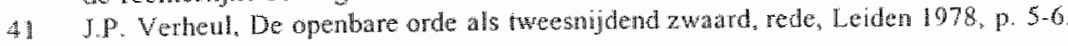




\section{Hoofdstuk 5}

Verheul laat zien hoe met name de Rechtbank Rotterdam met het openbare orde begrip ongaat om recht te kunnen doen aan de beoogde algemeengeldigheid van de Hague Rules. De Rechtbank stelt zich op het standpunt van de internationale openbare orde, maar dan in letterlijke zin opgevat: als "internationale orde, en behandelt het Nederlandse recht geheel op gelijke voet met andere rechtsstelsels." ${ }^{3 * 2}$ Deze rechtspraak kan als voorbeeld dienen van het op de voorgrond komen van het beginsel trow via het openbare orde begrip. Dit beginsel komt hier tot uitdrukking in de betekenis van het rechtens beschermen van een betrouwbaar verwachtingspatroon in het handelen van partijen in een specifieke materiele competentiesfeer.

Ook op het gebied van een staatstaak die Verheul het keren van onrecht noemt blijkt het openbare orde begnip in het ipr een centrale rol te kunnen spelen met het oog op doorwerking van beginselen van mensenrecht. In de materiële bevoegdheidssfeer van de familie dient de wetgever primaire verantwoordelijkheid van de ouders voor het kind te erkennen. Ingrepen van een overheid zijn uitsluitend te rechtvaardigen met het oog op bedreiging van het belang van het kind. ${ }^{4 y}$ Wat het belang van het kind eist, kan juridisch vertald worden in het begrip openbare orde. ${ }^{44}$ Verheul wijst erop dat het hier gaat om een werkelijk universele openbare orde. Die kan zich niet alleen tegen vreemd recht, maar ook tegen het eigen recht van de rechter keren. Bij invulling van openbare orde als "het belang van het kind" komen private en publieke dimensies van zorg op de voorgrond, in samenhang met priwate en publieke autonomie, in een telkens op het conerete geval toegespitste invulling van kinderbescherming.

In zijn beschouwing van vijfentwintig jaar rechtspraak van de Hoge Raad op het gebied van het ipr, sedert de wijziging wan de cassatiegrond schending van de wet in 1963 in schending van het recht, typeert Polak het openbare orde begrip in het ipr als "ultimum remedium." Hoewel hij de sparrzaamheid waarmee de Hoge Raad "met de bijl van de openbare orde zwaait" prijst, mag volgens hem "de zucht naar internationalisme en de vrees voor chauvinisme" een beroep op de openbare orde niet op voorhand frustreren. De opmars van een in het ipr vooral procedureel gericht beginsel vrijheid in de vorm van partijautonomie wordt bevestigd in de rechtspraak van de Hoge Raad. Polak vertaalt deze partijautonomie mede in rechtszekerheid. Partijautonomie op steeds meer gebieden van het ipr vergroot de voorspeibaarheicl voor betrokken partijen van de bevoegde rechter en van het toepasselijk recht. Datamee komt de onderlinge samenhang tussen vrijheid en trouw in het perspectief van mensenrecht in beeld. Hier wordt rechtszekerheid immers niet gezocht in een formeel systeem van verwijzingsregels, maar in de betrouwbaarheid van thet verwachtingspatroon van direct betrokken partjjen.

Verhenl1973, p. 115.116. Zik bv. Rb. Rotterdan 29 juni 1971, S\&S77.

Zie voor een diepgande analyse van de invulling wan het citerium "het belang wan het kind" als beschermingsbeginsel in het afstammingstecht het proefschrift van A.P.M. J. Vonken, Het internationale afstammingsecht in perspectief. Amhem 1987.

Dat dit veelvulig is gebeurd illustreert Vonken 1987 , p. 34 v. an de evolutie van de rechtspraak in het a fsiammingsrecht.

Polak 1990, p. 31 . 
Een ontwikkelingslijn in de richting van "wereldrecht" ziet Polak als de rode draad in de rechtspraak van de Hoge Raad in de door hem onderzochte periode. Het openbare orde begrip ziet hij daarin functioneren voor het tot aitdrukking brengen wan universele morele beginselen van recht. Dat vrijheid daarbij het leidend beginsel is, wordt bevestigd door het concept vam materiële competentiesferen en het beginsel van partijautonomie. In het verlengde daarvan zijn woorbeelden van doorwerking van de beginselen trouw (Hague Rules) en zorg (het belang van het kind) in de private en publieke sfeer nar voren gekomen.

\section{Openbare orde als ingang voor toetsing van vreemd recht aan het Europees mensen rechtenverdrag?}

Ik ga ervan uit dat doorwerking van drie beginselen van mensenrecht via het openbare orde begrip in het ipr intussen aamnemelijk is geworden. In deze paragraaf is de vreag of het begrip openbare orde ingang kan geven aan een toetsing van vreend recht aan mensenrechten zélf, die als positief recht zijn neergelegd in het Europees Verdrag voor de rechten van de mens (EVRM). ${ }^{46} \mathrm{Ik}$ neem aan dat de mogelijkheid van doorwerking van mensenrechten zélf via een universeel georiënteerd openbare orde begrip tevens iets zegt over doorwerking van beginselen van mensenrecht.

Vonken (1993) acht het juridisch technisch zeer wel mogelijk, vreemd recht te toetsen aan bepalingen van het EVRM via het begrip openbare orde. " Hij ziet echter veel bezwaren. Gelet op het specifieke karakter van de mensenrechten pleit er volgens hem veel voor deze niet via de openbare orde, maar op eigen kracht te laten gelden. directe toetsing aan het EVRM kan ik delen. Waar mensenrechten voldoende zijn uitgewerkt via interpretatie door het Europese Hof voor de rechten van de mens in Straatsburg, is toetsing via de openbare orde een onnodige omweg. Daarover zijn we het cens. Doen de bezwaren wan Vonken er dan nog toe? Ja, ik denk van wel.

Met het oog op de laatste noot in Vonkens studie is het wan belang of zijn bezwaren tegen toetsing via de openbare orde overtuigend zijn. In die noot benadrukt hij dat de openbate orde-exceptie een eigen bestaansgrond behoudt. Dit is volgens hem bijvoorbeeld het geval in de situatie dat het toepasselijke buitenlandse (stell: lerse) recht elke vorm van echtscheiding verbiedt. Omdat aan de bepalingen wan het EVRM geen recht op echtscheiding ontleend kan worden, zal volgens Vonken in een dergelijk geval slechts met een beroep op de openbare orde dit vreemde recht geweerd kunnen wordem. ${ }^{49}$ Wegen in $z 0^{\prime} n$

46. Zie woor samenhang tussen het EVIRM en de groeiende betekenis wan hel woor Nederland in 1979 in werking getreden International Verdrag inzake Burgerrechten en Politieke rechten (IVBPR) de IVBPR. Special van het NCM Bulletin 1994 , p. 765-944.

47 A.P.M.J. Vonken, De reflexwerking van de mensenrechten op het IPR, in Doorwerking wan mensenrechten, P.B. Cliteur en A.P.M.J. Vonken, red, Groningen 1993, p. 181 \%.

48 Wonken 1993, p. 183-184, met verwijzingen naar gelijkgezinde autaurs.

49 Vonkem, 1993, p. 184 verwigst naar de uitspraak van hel Europese Hof van 18 december 1986, NJ 1989, 97, (Alkema), in de zaak Johnston e a. tegen lenland. 


\section{Hoofdstuk 5}

geval de vele bezwaren van Vonken tegen toetsing via de openbare orde niet meer mee, of althans niet zwaar? Met het oog op de door hem genoemde "eigen bestaansgrond" van het begrip openbare orde lijkt het dienstig zijn bezwaren na te lopen.

Als een rechtstheoretisch bezwaar ziet Vonken dat mensenrechten die universele gelding pretenderen de openbare orde als cen "per definitie lager principe" nodig hebben om als toetssteen voor vreemd recht te kunnen dienen. De openbare orde is en blijft in zijn visie toegespitst op de eigen rechtsorde, terwijl de in het EVRM vervatte mensenrechten ook in een Europese rechtsorde gelden. Dit bezwaar lijkt niet overtuigend. Is openbare orde een "per definitie lager principe"? Pretendeert openbare orde, mét het respecteren van rechtsverscheidenheid per rechtskring, in de kern niet net zo goed een universele gelding als mensenrechten dat doen? Sterker nog, is openbare orde welbeschouwd in de kern niet zélf mensenrechtelijk? Ik denk aan de artikelen 28 en 29 van de Universelle Verklaring wan de rechten van de mens. Volgens artikel 28 heeft een ieder recht op een sociale en internationale orde waarin de rechten en vrijheden zoals in de Universele Verklaring neergelegd, volledig kunnen worden gerealiseerd. Dat kan vertaald worden als het recht op lokale, regionale en wereldwijde openbare ordes in de betekenis van mensenrechtordes. In artikel 29 van de Universele Verklaring worden de plichten van een ieder ten aanzien van deze mensenrechtelijke openbare ordes verwoord.

Als een ander bezwaar tegen toetsing via de openbare orde ziet Vonken de schijn van paternalisme die het nationale openbare orde begrip kan oproepen, vooral als er grote cultuurverschillen zijn tussen de forumstaat en de vreemde staat. Ook dit bezwaar overtuigt niet. Waarom zou de nationale rechter niet, evenals de internationale rechter, kunnen uitgaan van de idee van een getrapte rechtsorde? Naast nationale rechtsordes waarmee de rechter in het ipr te maken krijgt kent deze getrapte rechtsorde een Europese verdieping, zoals Vonken zelf stelt. ${ }^{50}$ Daarmee correspondeert een Europese openbare orde die op zijn beurt niet gesloten is voor een verdere ontwikkeling in de richting van een wereldorde.

Als doorslaggevend bezwaar ziet Vonken, dat voor strijd met de nationale openbare orde een zekere mate van betrokkenheid van de zaak met het land van de rechter is vereist. Daardoor kan het geldingsbereik van de mensenrechten. volgens hem door min of meer toevallige omstandigheden worden beperkt. Het EVRM kent geen expliciet betrokkenheidsvereiste en ook de jurisprudentie van de Straatsburgse instanties geeft hierwoor volgens Vonken geen aanknopingspunt. Zo'n vereiste is volgens hem ook moeilijk te rijmen met de wens van de verdragstaten om aan een ieder die in aanraking komt met hun rechtssysteem een minimum aan bescherming te garanderen. Vanuit praktisch oogpunt acht hij de verdragsrechtelijke "margin of appreciation" elastisch genoeg om adequaat op eigenaardigheden van internationale verhoudingen te kunnen inspelen.

Vonkens bezwaar ten aanzien van het betrokkenheidsvereiste kan ik ook in zijn eigen betoog niet goed platsen. Wijst het garanderen door verdragstaten van "een minimum aan 
bescherming" aan "ieder die in aanraking komt met hun rechtssysteem" niet zélf al op een praktisch vereist minimum aan betrokkenheid van de zaak met het land van de rechter? En is in de "margin of appreciation" die de Stratsburgse instanties met het oog op culturele verschillen de verdragstaten gunnen niet ók de mate van betrokkenheid van de verdragstaat in het openbare orde begrip ingecalculeerd? Een redenering van Mayer, die Vonken met instemming bespreekt, geeft, als ik goed zie, een mooi voorbeeld van de werking van het betrokkenheidsvereiste. ${ }^{5}$ Mayer trekt de redenering van het Straatsburgse Hof in de zaak Soering tegen het Verenigd Koninkrijk door naar het ipr. ${ }^{52}$

In de zaak Soering/VK gat het on de uillevering van Soering door het Verenigd Koninkrijk (verdragstaat) aan de Verenigde Staten van Amerika (niet-verdragstaat), waar Soering de doodstraf te wachten staat. De Britse regering verweert zich met het argument, dat voor deze mogelijk onmenselijke behandeling niet het Verenigd Koninkrijk als verdragstaat verantwoordelijk is, maar de Verenigde Staten als niet-verdragstaat. In de redenering van het Straatsburgse Hof gaat het echter om de verantwoordelijkheid van de door Soering aangeklaagde staat, het Verenigd Koninkrijk, voor de uitlevering zélf. Deze witlevering stelt Soering direct bloot aan het gevaar van onmenselijke behandeling. Doorgetrokken naar het ipr gaat het er om of de rechter zélf door toepassing van wreend recht overeenkomstig zijn verwijzingsregel het EVRM schendt.

De vraag rijst dan: hoe ver gaat dit? "Dient het privaatrecht van de hele wereld aan de Europese standaard te worden getoetst?" 53 Deze vraag voert naar een in het ipr bekend onderscheid tussen de buten- en de binnengrens van de openbare orde. Als een regel wan vreend recht niet absoluut onaanvaardbaar is (de buitengrens van de openbare orde) hang? het van de betrokkenheid wan Nederland bij de situatie af (de binnengrens van de openbare orde) of die vreemde regel in Nederland kan worden toegepast. Naamate betrokkenheid van Nederland minder is, komt het vreemd recht eerder voor toepassing in aanmerking. Sterker nog: in termen van mensenrecht kan met het oog op culturele verschillen de toepassing of erkenning van een vreemde regel of beslissing een eis van een door het EVRM gewaarborgd recht zijn, juist ondát de betrokkenheid van Nederland daarbij minimaal is. Kortom: bij het betrokkenheidsvereiste gat het on de "variabele kracht van centrale beginselen van ons recht" al naar gelang de mate van betrokkenheid van de Nederlandse rechtsorde bij de gegeven situatie.

5 P. Mayer, La Convention earopéente des droils de lhomme ef l'application des normes étrangè res, in Vonken 1993 , p. 172 v. Vgl. J.H.A. wn Loon, De wisselwerking tussen intemationat privantrecht en rechten van de mens, in Grensoverschrijdend privaatrecht, Deventer 1993, p. $145 \%$

52 Europese Hot 7 juli 1989, NJ 1990, 158, nn. Alkerna.

5.3 Van Loon, 1993 , p. 146.

54 H.U. Jessurun d'Oliveira, Openbare orde en rechtsvergelijking, in 'T Exempel dwinght, Kisch-bundel,

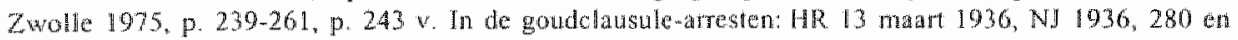
281; HR 11 rebruan 1938. NJ 1938,787, heef de Hoge Raad matstaven geformulecid voor de toessing van vreemd recht aan de openbare orde, al gebevorde dat uiterard nog niet met het oog op het toen nog njet bestaande EVRM. Deze maststaven staan bekend als de button- en de binnengrens wan de openbare orde. Vgl. Saluweplanne 1989, p. 92. 


\section{Hoofdstuk 5}

In verband met het betrokkenheidswereiste en de redenering van Mayer in de zaak Soering/VK schiet mij een opmerking van Kranenburg (1895) te binnen, die hij toeschrijft aan Fiore. ${ }^{55}$ Deze opmerking komt hierop neer. In het ipr gaat het er niet om, dat een vreemde wet in strijd is met de openbare orde van het land van de rechter. Het komt er op aan of een rechtshandeling die men krachtens een vreemde wet in het land van de rechter will verrichten, dan well het gevolg van een rechtshandeling waarop men zich in het land van de rechter beroept, in strijd is met de openbare orde van het land van de rechter. Deze opmerking acht Kranenburg van belang, terecht denk ik, omdat de Nederlandse staat in zijn taak van "justicier humanitaire" schromelijk te kort zou schieten "wanneer hij den wreemdeling geheel onnodig ging catechiseren en zijne wettig verkregen rechten in twijfel ging trekken, waar de wijze wâap hij ze verkreeg geheel buiten ons rechtsgebied ligt.

Aan de hand van de redenering van Mayer in de zaak Soering/VK, de opmerking van Fiore en het binnengrenscriterium van de openbare orde kan de vraag hoe ver de toetsing van vreemd recht aan het EVRM via de openbare orde moet gaan, per geval genuanceerd beantwoord worden. Dat maakt Vonkens bezwaar tegen het vereiste wan betrokkenheid bij toetsing van vreemd recht aan het EVRM via de openbare orde zwak.

Als laatste argument tegen toetsing van vreemd recht aan het EVRM via de openbare orde werpt Vonken op, dat de interpretatie van de mensenrechten in laatste instantie plaats vindt door de Straatsburgse instanties. Anders dan bij een van land tot land variërende invulling van de openbare orde, kan bij zelfstandige toetsing aan het EVRM een zekere mate van uniformiteit worden bereikt. Voor een "Europese" interpretatie van de mensenrechten valt inderdaad alles te zeggen in gevallen waarin deze uitleg duidelijk is. Maar als dat niet het geval is? Een toetsing via de openbare orde lijkt dan juist een voordeel te hebben. De nationale rechter zou zich in zo'n geval ten opzichte van de Straatsburgse instanties woorzichtig kunnen opstellen en tegelijkertijd via de openbare orde een actieve bijdrage aan de Europese mensenrechtontwikkeling kunnen leveren. Als voorbeeld hiervan geef ik het door Vonken zelf opgeworpen geval van het Ierse echtscheidingsverbod.

In de zaak tegen Ierland waar Vonken naar verwijst komt bet Straatsburgse Hol tot het oordeel, dat aan het EVRM wél een recht om te huwen (artikel 12 EVRM) maar géen recht op echtscheiding kan worden ontleend. Is de nationale rechter in de ogen van Vonken niet gehouden om deze "Europese" interpretatie te volgen? Of mag de Nederlandse rechter lerland, dat "langzamerhand als enige geen echtscheiding kent", tot de "Europese openbare orde" roepen waar het Hof in Straatsburg dat nalaat?

55 Kranenburg 1895. p. 88 verwijst naar Fione, Dron International Privé (Antoine) I 275.

5.6 Krancuburg 1895 , p. $90-91$.

$57 \mathrm{Vgll}$. de noot wan Alkema onder de uitsprak, $\mathrm{NJ} 1989,97$, die in werband met de tweestrijd ussen "activism" en "self restraint" wan constitutionele rechtscolleges en van het Europese Hof o.a. verwijst nat G.J. Wiarda in Ad Personam (Enschede-bundel) en in Rechterlijke voortvarendheid en rechterijke terughouding bij de toepessing van het ECRM, "s-Gravenhage 1986. 
Volgens artikel 12 EVRM hebben mannen en vrowwen wan huwbare leeftijd het recht te huwen en een gezin te stichten wolgens de nationale wetten die de uitoefening van dit recht beheersen. De woorden "het recht te huwen" slaan volgens het Straatsburgse Hof in hun normale betekenis niet op de ontbinding van het huwelijk. Bovendien verwijst deze bepaling uitdrukkelijk naar nationale wetten. Het Hof acht zich niet bevoegd om door middel van evolutieve interpretatie uit het EVRM een recht af te leiden dat daarin niet van het begin is opgenomen. Klagers zijn in de visie van het Hof ook niet in een positie, analoog aan die van personen die in het buitenland woonachtig zijn en voor wie echtscheiding door middel van erkenning van een buttenlands echtscheidingsvonnis wel mogelijk is.

Als artikel 12 EVRM in de Nederlandse rechtsorde wordt geñnterpreteerd, dan mag het mensenrechtelijk beginsel vrijheid (in dit geval on te huwen) niet verworden tot wettelijke dwang om, eenmaal gehuwd, een wettelijk huwelijk onder alle omstandigheden levenstang in stand te houden. De aan vrijheid gekoppelde beginselen zorg voor elkaar en voor thit het huwelijk geboren kinderen en onderlinge trom spelen weliswar in het huwelijksreclit vanouds een prominente rol. Deze zorg en trouw kunnen echter niet zover voeren dat ze wrijheid, als leidend beginsel van mensenrecht, doen verdwijnen achter een wettelijke regeling die vrijheid om te huwen omzet in levenslange dwang om gehuwd te blijven. Het beginsel vrijheid blijft het primaire richtsnoer voor iedere "deugdelijke rechtsverwerkelijking" (om met woorden van Kranenburg (1895) te spreken). Met een redenering in deze geest zou de Nederlandse rechter in een concreet geval toepassing wan het lerse echtscheidingswerbod inderdaad wia het openbare orde begrip in de Nederlandse rechtssfeer kumnen weren.

Aan het Nederlandse echtscheidingsreclat in samenhang met het openbare orde begrip is ook te illustreren, hoe een juridische interpretatie van "openbare orde" achter kan blijven bij zich ontwikkelende rechtsopvattingen. In een arrest uit 1907 acht de Hoge Raad het Nederlandse echtscheidingsrecht "van openbare orde". ${ }^{58}$ Dat houdt in dat de Nederlandse rechter op alle bij hem aangebrachte vorderingen tot echtscheiding het Nederlandse echtscheidingsrecht dient toe te passen. Buitenlands recht komt in geen geval voor toepassing in aammerking. Pas in 1973 breekt de Hoge Raad met deze leer. In zijn arrest van 23 februari 1973, betreffende een scheiding van tafel en bed wan partujen die de Duitse nationaliteit hebben, overweegt de Hoge Raad dat het niet uitgesloten is dat een vordering tot echtscheiding of scheiding van tafel en bed, aangebracht woor de Nederlandse rechter, door ander dan Nederlands reclyt wordt beheerst. ${ }^{59}$

Met de uitspraak van de Hoge Raad uit 1973 is echtscheiding of scheiding van lafel en bed niet meer "van openbare orde" in die zin dat uitsluitend Nederlands recht wan toepassing is. Dat neemt niet weg dat volgens artikel 1 van de Wet conflictenrecht echtscheiding van 25 maart 1981, Stb. 166, toepassing van Nederlands recht nog steeds hoofdregel is.

58 HR 13 december 1907 W. 8636, Boon-Sohmidt. VgL. Strikwerda 1997, p. 78-79; Jessumn d'Oliveira $1975.9239 \%$

59 NJ 1973, 366* Strikwerda 1997, p. 120-121; Jessurun d'Ohiveina 1975, p. 239, spreckt van de ontstatelijking van het familierecht. Het betreft hier de zatak die ik in de inleiding van dit hoofdstuk als voorbeeld heb gebruikt. 
Strillwerda spreekt in dit verband over een te grote exportpretentie van Nederlands echtscheidingsrecht In de kwestie van het lerse echtscheidingsverbod ziet Vonken in het undragen van deze exportpretentie via het openbare orde begrip kennelik geen overwegend bezwat. Het begrip openbare orde moet dan echter gevrijwaard kunnen worden van de door Vomken opgeworpen bexwaren. Drie beginselen van mensenrecht kounen dawibij dienst doen als richtsnoer.

\section{Openbare orde als laatste kwaliteitstoets in het ipr}

Het in dit hoofdstuk in verband met voorrangsregels ter sprake gekomen Alnati-arrest van de Hoge Ruad (1966) wordt wel gezien als een Nederlands novm met exportkwaliteit. Dararan getuigt het feit dat het mede model heef gestaan voor artikel 7 van lyet EEGVerbintenissenverdrag (1980). Volgens antikel 2 van dit verdrag heeft het universele werking. Dat betekent dat het ipr ten aamzien wan overeenkomsten geheel door dit verdrag word behecrst, ook als het overeenkomsten betreft die geen direct aanknopingspunt met de verdragstaten hebben. Artikel 3 bevat als hoofdregel van het verdrag het beginsel varn partijatonomie, de vrijheid van partijen zelf het op hun overeenkomst toepasselik rechisstelsel aan te wijzen.

In het EEG-Verbintenissenverdrag is een oplopende lijn van drie categorieen dwingend recht te vinden, die de partijautonomie kumnen doorbreken: dwingende bepalingen, bepalingen van bijzonder dwingend recht en openbare orde. ${ }^{63}$ Met het oog op openbare orde als symoniem voor dwingend recht kan deze differentiatie beschouwd worden als voorlopig resultaat van het steeds verder uitkistalliseren en concretiseren van het openbare orde begrip. De eerste categorie, dwingende bepalingen, betreft met name consumenten(artikel 5) en arbeidsovereenkomsten (artikel 6). Bij deze overeenkomsten is de partijautonomie beperkt ter bescherming van consumenten en werknemers tegen een door de wederpartij opgelegde keuze voor een consumenten- of werknemersonvriendelijk rechtsstelsel." In dit type dwingend recht komt het aspect zorg (bescherming van de zwakkere partij) expliciet nar voren bij het streven nat evenwicht in de machtsbalans bij het uitocfenen wan betrowbare partijatutonomie als aspect van wrijheid.

60 Strikwerda $1991, \mathrm{p}, 120$

61 Roelof Kotting, Extrateritoriale wetgeving, preadwies NVIR, Deventer 1984, p. 117. EEG-Verbintenissenverdrag, Trb. 1980, 156. Zie ook Vlas 1989, p. 9.

62 Zie voot een overzich van dil op 1 sept. 1991 voor Nederland in werking getreden verdrag $I$. Strikwerda, Kromiek van het ipr, NJB 1991, p. 1287-1298, p. 1294 v.

63 Zie hicroker M. . Polak, Arbeidsverhondingen in het Nederlandse intemationaal privaatrecht, Deventer 1988, p. 98 w.

64 Polak 1988, p. 100;. Kotting 1984, p. 122. L. Strikwerda, De hanteebaarleid van het intemationaal privatrech, in Grensoverschrijdend privantrecht, Deventer 1993, p. 245, bespreekt artikel 6 lid I van het vertrag als voorbeld van het ingewikkelde van het ipr. Zie voor de verhouding van afd. $6.5 .2 \mathrm{~A}$ BW tot de art. 3-7 van het verdrag A.S. Hartkamp, Intemationale overeenkomsten en nieuw dwingend recht, in en burdel wan de Offerhatus Kring, Deventer 1987 , p. 93-104, p. 96 \% 
Artikel 7 lid 2 van het EEG-Verbintenissenverdrag slat op bepalingen van het land wan de rechter die "het geval dwingend beheersen". Dat zijn bepalingen in de tweede categorie (bijzonder dwingend recht). Het betreft hier de eerder besproken voorrangsregels, die in ontwikkelingsperspectief als uitwerkingen van het openbare orde begrip kunnen worden gezien.

In artikel 16 van het verdrag zijn voorschriften wan de derde categorie (openbare orde) te vinden." Volgens artikel $16 \mathrm{kan}$ de toepassing van een bepaling van het door het verdrag aangewezen recht slechts terzijde worden gesteld als deze toepassing "kennelijk onverenigbaar is met de openbare orde van het land van de rechter." Daarmee is volgens het toelichtend Rapport bij het verdrag bedoeld "dat de rechter niet het vreende recht in abstracto, maar de concrete toepassing daarvan op het voorliggende geval moet bezien in het licht van zijn eigen fundamentele beginselen. ${ }^{* 660}$

In de oplopende reeks van dwingend recht, bijzonder dwingend recht en recht van openbare orde komt het openbare orde begrip in artikel 16 van het EEG-Verbintenissenverdrag naar voren als laatste kwaliteitstoets. Een volgens de overige regels van ipr toepasselijke norm kan in laatste instantie aan de hand van het openbare orde begrip worden geweerd. ${ }^{67}$ Het gaat in dit verdragsartikel om kennelijke onverenigbaarheid van toepassing van vreemd recht met fundamentele beginselen van het land van de rechter. Dat doet denken aan de gedachtengang zoals die naar voren is gekomen ten aanzien van de zaak Soering contra het Verenigd Koninkrijk. Waar het on gaat is of de rechter door toepassing van vreemd recht fundamentele beginselen van mensenrecht schendt, die in zijn eigen recht dienen te worden geëerbiedigd. In deze opvatting past het openbare orde begrip inderdaad als een laatste kwaliteitstoets in de lijn van deze studie.

In 1917 concludeert Kollewijn dat de openbare orde de rechter in het ipr geen richtsnoer geeft om te vinden wat recht is. In technisch juridische zin kan dat ook in 1998 nog beweerd worden. Dat vloeit voort uit het in beginsel algemeen inzetbare karakter van het openbare orde begip als open algemeen rechtsbegrip. Mijn stelling daarover wordt in dit hoofdstuk in diwerse toonaarden bevestigd. Maar ook de tweede stelling, over de notie mensenrecht als morele kern wan het tegenwoordige recht, wordt in de geschetste ontwikkeling van het ipr bevestigd. In deze ontwikkeling past doorwerking van drie beginselen van mensenrecht via het begrip openbare orde. 38; Contractenrecht X (Struycken) No. 3, p. X-35, X-95 (suppl. 54/okt, 1981).

Zie voor een checklist als leidrad voor de behandeling van buitenlandse nomen Th. M. de Boer en R. Kotting, President Wijnholt vs President Reagan, NUB 1982, p. 1177-1186, p. 1185, nood 42. 



\section{PRIVAATRECHT}

\section{Inleiding}

Het internationaal privaatrecht heb ik aan het begin en het internationaal publiekrecht aan het einde van dit tweede deel gesitueerd. In het middenstuk komen "bimnenlandse" privataten publiekrechtelijke onderwerpen aan bod. Daarbij moet aangetekend worden dat het onderscheid tussen privaatrecht en publiekrecht niet altijd gemakkelijk to maken is. Er is sprake van een vergaande vermenging.' Toch kan nog uitgegaan worden van de idee dat privaatrecht primair relaties tussen burgers onderling betreft terwijl in het publiekrecht de overheid steeds mede van de partij is. Zo gezien omvat publiekrecht "al het recht inzake het overheidsingrijpen in de maatschappij."2 Als aanloop naar het privaatrechtelijk contractenrecht in dit hoofdstuk en publiekrechtelijke onderwerpen in het volgende hoofdstuk schets ik hierna de ontwikkeling van privaat- en publiekrecht op het grondgebied waartoe thans Nederland behoort (par. 2).

De keuze voor het contractenrecht als privaatrechtelijk onderwerp is ingegeven door de overweging dat het tot de harde kern van het privaatrecht behoort. Daarbij komt dat sedert de invoering van het Burgerlijk Wetboek in 1838 het begrippenpaar openbare orde en goede zeden de grens tussen het rechtsgeldige en het nietige contract markeert. In het in 1992 ingevoerde Burgerlijk Wetboek zijn een aantal in de rechtspraak ontwikkelde vernieuwingen opgenomen, maar het begrippenpaar openbare orde en goede zeden heeft als juridische constructie deze vernieuwing overleefd. Na een korte schets van deze juridische constructie (par. 3) komt de combinatie van de begrippen openbare orde en goede zeden aan bod. In het vorige hoofdstuk hebben we gezien hoe Kranenburg (1895) kiest voor het openbare orde begrip en dit loskoppelt wan het "schaduwbegrip" goede zeden. Vier jaar later kiest Van der Ley (1899) voor het begrip goede zeden. ${ }^{3}$ Daarbij zet hij niet het begrip openbare orde als ongrijpbaar of "te glibberig" aan de kant, zoals Kranenburg dat met de goede zeden doet. Van der Ley is van mening dat de component openbare orde naast de goede zeden overbodig is. Volgens hem drukt de component goede zeden precies het essentiele van het openbare orde begrip uit: doorwerking van moraal in het recht (par. 4).

Dat het begrip goede zeden zich goed leent voor doorwerking van morele aspecten in het recht, ligt voor de hand. Zowel in de juridische traditie als in alledaags taalgebruik geeft het witdrukking aan opvatingen over maatschappelijke behoorlijkheid. Naast het bogrip-

1 Osmose ussen publiek- en privaarecht themarummer Ass Acqu 1987, ni. 5, p. 273-372.

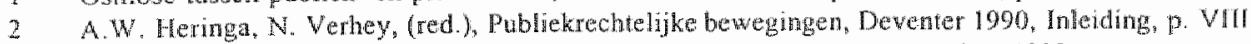

3 IN. Wan der Ley. Overeenkomsten, in strja met de goade zeden, Amsterdam 1899. 
penpaar openbare orde en goede zeden spelen echter ook andere open begrippen een belangrijke rol bij doorwerking van zedelijke beginselen in het recht. Met het oog daarop dringt zich wen vergeliking op van Nieuwenhuss" "Drie beginselen van contractenrecht" met drie beginselen van mensenrecht (par. 5), die deze confrontatie doorstan. In de laatste paragraf onderzock ik doorwerking van drie beginselen van mensenrecht in drie fasen: voor, tijdens en na het sluten van het contract (par. 6).

\section{Ontstaan van het Nederlandse privat-en publiekrecht}

In de oudgermaanse tijd", ongeveer tot de zesde eeuw, handhaven op het grondgebied wartoe nu Nederland behoort "vrije" boeren en "edelen" (hereboeren-grootgrondbezitters), als heersers en rechters binnen hum eigen familie/bedrifsverband een op overgeleverd gewoonterecht gebaseerde rechtsorde. Vorsten komen waaschijnlijk op doordat jonge mannen uit verschillende families aansluiting zoeken bij een beroend strijder, als diens leerlingen en strijdmakkers. ${ }^{\gamma}$ Als familie- en kleine vorstenverbanden grotere eenheden vormen ontstaan stammen. In stamvergaderingen komen alle vrije mannen op vaste tijden in vergadering bijeen. In kwesties van gemeenschappelijk belang die aan de vergadering. worden woorgelegd beslissen zij over wat naar gewoonte rechtens is. Interne kwesties bimen de kleinere verbanden blijven ter beoordeling van de pater familias of van de vorst als hoofd wan zijn eigen huishouding. Hier tekent zich een feitelijk onderscheid af tussen recht in de private sfeer en recht in de publieke sfeer.

In de loop van de zesde tot omstreeks de elfde eeuw worden alle hoorden van kleine verbanden "fideles", getrouwen van een Frankische koning. Op een "rijksdag" bespreekt de koning zijn recht met de hoogste klasse van zijn fideles. De "consensus" die de aanwezigen geven betekent niet instemming, mar "erkenning als recht". In de loop van de negende eeuw daalt de macht van de koning zo ver dat "consensus" geweigerd kan worden." In beginsel leeft elke groep dan nog naar overgeleverd gewoonterecht. In stamvergaderingen wordt echter geleidelijk ook nieuw recht gekozen. Al doende vervaagt het onderscheid tussen gewoonterecht en gekozen recht. Doordat het steeds moeilijker wordt om tot eenparigheid van stemmen te komen ontstat een regel die voorschrijft dat de minderheid de meerderheid moet volgen. Geleidelijk ontwikkelt deze procesregel zich tot het principe dat de meerderheid beslist, maar dat de mindertheid recht houdt op respect voor har eigen standpunt."

J.H. Nienwenhuis, Drie beginselen van contractenrecht, Deventer 1979.

$5 \quad$ Ik volg het overzicht en de indeling in tijdvakken van Garbenzon/Algra 1987; zie p. 27-32 van dil werk voor een literatuuroverzicht van wereld-, Europese en Nederlandse rechtsgeschiedenis.

6 Gotbenzon/algra 1987, p. 40 .

7 Het woord vorst verwigt naar voorste, eersie, Gerbenzon/Algra 1987, p. 40, waarschiwen: "Men hoede er zich voor, de Germanen als een min of meer homogeen "ras" te zien" het was een ratjetoe van allerlei groepen en groepjes, vaak weinig to "apatheid" geneigd ten opzichte van de volkeren. waarmee zij tijdens de volksverhuizing in contact kwamen."

8 Gerbenzon/lgra 1987, p. 60.

9 Gerbenzont/Agra 1987, p. 23-24. 
In de landsheerlike periode, wan omstreeks het begin wan de elfde eeuw tot 1581, ontstan een groot aantal staatjes, elk geregeerd door een landsheer (hertog, markgraaf, graat, bisschop) die praktisch het hoogste gezag heeft. In de loop van de dertiende en do veertende eeuw stijgt het gezag van de koning geleidelijk weer boven dat van zijn landsheren wit. Daarbij heeft hij krachtige steun van het "geleerde" recht van de juristen, in het kader wan de "receptie" van het klassieke Romeinse recht. "Achter de "receptie" van het Romeinse recht staat naast herleving van het gezag van de antieke cultuur en van een oude Germaanse traditie waarin het Romeinse recht als het gemeenschappelijk jus commune wordt gezien een derde kracht. Ik bedoel de opkomst van het modeme wetenschappelijk denken. ook op gebieden als theologie en filosofie. In dit knachtenveld ontwikkelt het recht zich meer en meer als een wetenschap van Romeins en kerkelijk recht. Het "geleerde" onderseheid dat juristen maken tussen priwattrecht en publiekrecht werkt het latere gebruik van het begrip openbare orde in het privaatrecht in de hand, als grens aan de private vrijheid, met het oog op publicke belangen.

In 1581 komt de Republiek der Verenigde Nederlanden tot stand. In deze statenbond verwult de onder de bedreiging van de Spaanse legers in 1579 tot stand gekomen Unie van Utrecht de functie van grondwet. "In kerkelijke zaken zouden de gewesten nar eigen goedvinden besluiten, mits ieder in zijn persoonlijke overtuiging vrij zou blijven en dus wervolging om den gelove was uitgesloten." Met deze erkenning van de vrijheid van geweten in artikel XIII Unie Van Utrecht, als persoonlijke godsdienstige overtuiging, komen we terecht bij de eerste positivering van de idee van rechten van de mens in een concreet vrijheidsrecht. ${ }^{12}$

Met de Bataafse omwenteling komt een einde aan de feodale vermenging van privaatrecht en publiekrecht. "Privaatrecht en publiekrecht worden zelfs streng gescheiden, zulks onder" afschaffing wan privaatrechtelijke beschikkingsmacht over openbare zaken (heerlike rechten). Het streven was gericht op een zo groot mogelijke overheidsonthouding in de private rechtsorde en op de genoegzaamheid van het toen bestaande publiekrecht voor de primaire overheidstaak (openbare orde en veiligheid)." In de Staatsregeling voor het Bataafsche volk (1798) staat in artikel 1 , in navolging van artikel 2 van de Franse Verklaring vat de Rechten van de Mens en Burger van 1789, onder het hoofd Algemeene Beginselen: "Het oogmerk der maatschappelike vereeniging is beveiliging van persoon, leven, eer en goederen en beschaving van verstand en zeden." In de cerste Nederlandse grondwet (1814) worden enkele grondrechten opgenomen, betreffende justitiele waarborgen, de godsdienstvrijheid, het onderwijs en de ammenzorg. In 1815 wordt de grondwet angevuld met de vijheid van drukpers, het recht van petitie en de onschendbaarheid wan de woning. In 1848 worden bepalingen over het recht tot vereniging en vergadering, de onschendbaarheid

10 Gerbenzon/Algra 1987, p. 94 v

11. Van der Pot/Donner/Prakke 1995, p. 87. Zie yoor de tekst wan de Unie van Ufrecht Van Hasseli 1987.

12 Zie verder hoofdstuk \&, par. 2.

13 J.C. Schroot, Privaatrecht/publiekjecht, strijd on het primat, in Publick Domein 1989, p. 157-159, p. 157. 


\section{Hoofdsusk 6}

van het briefgehem en de wrijheid van onderwijs toegevoegd.. ${ }^{4}$ De beide wereldoorlogen geven een belangrijke impuls aan het internationaliseren van grondrechten. ${ }^{15}$

De ontwikkeling van de liberale rechtsstaat in de richting van de democratische sociale rechtsstaat gaat gepaard met een enorme groei van publiekrecht. Op theoretisch niveau ontbrand een strijd om thet primaat van privaat- of publiekrecht. In $1909 \mathrm{komt}$ R. Kranenburg in zijn dissertatie ${ }^{16}$ tot de conclusie dat er geen principieel onderscheid te maken walt tussen privaatrecht en publiekrecht. Volgens Schroot heeft hij daarmee "de kiem gelegd voor de later ontwikkelde opvatting, dat het priwaatrecht en het publiekrecht gelijkwaardige delen van de rechtsstof zijn, die toch in wezen een eenheid vormen."1? Het enige waarover rechtsgeleerde opvattingen inzake het onderscheid tussen privaatrecht en publiekrecht tot nu toe duidelijkheid verschaffen schijnt te zijn dat het onderscheid onduidelijk is. ${ }^{18}$

\section{Het begrippenpaar openbare orde en goede zeden in het contractenrecht}

In artikel 1356 oud BW worden vier juridische eisen gesteld woor het tot stand komen van een overeenkonst. Drie daarvan zijn in het BW na 1992 behouden gebleven: 1) handelingsbekwaamheid van de contracterende partijen, 2) toestemming van partijen en 3) een bepaald onderwerp. Ten aanzien wan thandelingsbekwaamheid is de hoofdregel, dat een ieder bevoegd is verbintenissen aan te gaan, indien hij daartoe niet onbekwaam is verklaard door de wet. Handelingsonbekwaam zijn volgens de wet minderjarigen en onder curatele gestelden. Het tweede vereiste, de toestemming van partijen, is in het BW neergelegd in een regeling voor het tot stand komen van een overeenkomst door wilsovereenstemming tussen partijen over een aanbod en de aanvaarding (artikel 6: 217 BW). Met het oog op de eis van wilsovereenstemming spelen juridische figuren zoals dwang, dwaling en bedrog een rol. Die zijn bedoeld om belemneringen in de vrije wilsvorming van contracterende partijen te voorkomen. Al deze rechtsfiguren, zoals intussen ook het leerstuk misbruik van omstandigheden, zijn gericht op het waarborgen van vrijheid van partijen bij het angatan van het contract. De derde eis, een bepaald onderwerp, dient om to waarbotgen dat prestaties waantoe de contractpartners zich tegenover elkaar verplichten voor hen voldoende duidelijk zijn.

14. Meij wan Bruggen 1989, p. 14, verwijst naar Van Hasselt 198\%, p. 17, over de Staatsregeling; Burkens 1989. p. 14, over de Grondwet 1814; Melwissen 1284, p. 140, over uitgebreide negeling van de vrigheid van godsdienst in 1848; Crijns 1982, p. 440, over de onderwijspacificatie 1917, Meuwissen 1984. p. 83, over jurtsprudentie van de Hoge Rad.

15 Daarover verder in hoofdstuk 8.

16 R. Kranenburg, De tegenstelling tussen publiek- en privaatrecht en de ontwerpen tot regeling der administratieve rechlspraak, LeidenGroningen 1909.

17 Schroot 1989, p. 159.

18 Volgens Schroot 1989, p. 159 , heeft Tak met deze conchusie nog altijd geljik. A.Q.C. Tak, Overheidsbestum en Privatrecht, A lphen a.d. Rijn 1978. Selroot geeft een korte schets van de strijd van theoretici over het primat wan prival- of publiekrechi sedert de tweede helft van de vorige eeuw en de huidige beweging in de richting van gelijkwaardigheid wan de beide rechtwelen die in wezen een eenheid vomen. 
Bij het vierde vereiste voor het tot stand komen van een contract komt het openbare orde en goede zeden begrip aan bod. Volgens artikel 1371 oud BW is een overeenkomst die zonder oorzaak of uit een valse of ongeoorloofde oorzak is aangegaan krachteloos. Volgens artikel 1373 is sprake van een ongeoorloofde oorzak, als datgene wat partijen met de overeenkomst beogen bij de wet verboden is of in strijd is met de goede zeden of de openbare orde. Zoals ze naasi de wet worden genoemd, verwijzen goede zeden en openbare orde hier naar ongeschreven recht.

Op 1 januari 1992 is woor het algemeen gedeelte van het overeentomstenrecht het nieuw BW in werking getreden. ${ }^{19}$ Daarin is het vereiste dat een overeenkomst een geoorloofde oorzak moet hebben niet meer te winden. Dat wil niet zeggen dat de materie waar het om gat vervallen is. Deze materie is ondergebracht in een regeling die alle rechtshandelingen besiaat. Daaronder vallen ook overeenkomsten. Een rechtshandeling is nietig als ze door inhoud of strekking in strijd is met de goede zeden of de openbare orde (artikel 3:40 $\mathrm{BW})^{20}$

\section{Doorwerking van moraal via het begrippenpaar openbare orde en goede zeden}

Op basis van een reeks argumenten van historische, utilitaire, wettelijke en intemationaal privaatrechtelijke aard komt Van der Ley (1899) tot de bevinding, dat in artikel 1373 oud BW van het begrippenpaar openbare orde en goede zeden de component openbare orde gemist kan worden. Als de voorkeur wordt gegeven aan het behoud van de combinatie openbare orde en goede zeden, acht hij het nodig dat openbare orde synoniem wordt verklaard met haar "tweeling-expressie" goede zeden." Het begrip goede zeden geeft volgens hem uitdrukking aan doorwerking van moraal in het recht. En juist dát ziet Van der Ley als het essentiële van de openbare orde.

Van der Ley maakt onderscheid tussen wat hij een positieve en een negatieve doorwerking van de moraal in het recht noemt. Positieve doorwerking ziet hij in gevallen waarin "goede trouw" tot rechtseis is gesteld. Met negatieve doorwerking bedoelt hij de situatie warin het recht bescherming an het immorele ontzegt. Als voorbeeld daarvan noemt hij artikel 14 Wet Algemene Bepalingen. ${ }^{22}$ De negatieve doorwerking van de moraal in het recht komt volgens Van der Ley óok tot uitdrukking in artikel 1371 jo artikel 1373 oud BW. Overeenkomstig deze wetsartikelen zijn contracten die in strijd zijn met de openbare orde of de goede zeder nietig.

19 KB 20 tebuari 1990,5 b. 90.

20 Als de grond van nietigheid slechts een deel wan de rechtshandeling betref, kan deze voor het overige in stand blijuen, voor zover ze niet in een onverbrekelijk werband stat met het nietige deel van de rechshandeling (artikel $3: 41 \mathrm{~B}$ W).

21 Van der Ley 1899, p. 23

22 De in hoofustuk 5, par. 3 ter sprake gekomen bepaling over nietigheid wan overaenkomsten en andere privaatrechtelike handelingen. Stelling if bij het proefschrift van Van der Ley 1899, luidt: "Het woord "openbare orde" in artikel 14 A.B. moet wervallen." 


\section{Hoofdstuk 6}

Om te proberen enige lijn te ontdekken in rechterlijke uitspraken waarin contracten nietig worden verklaard wegens strijd met de goede zeden, gaat Van der Ley op zoek naar een structuur van het immorele contract. Daartoe maakt hij onderscheid tussen een formele en een materiêle vraag. De formele vraag of rechtsvraag geeft aan wat door de zedelijkheid beantwoord moet worden. Of dat vervolgens ook feitelijk in strijd is met de goede zeden is volgens hem niet door het recht doch slechts door de moraal te beantwoorden. De consequentie van deze opvatting is, dat slechts de formele rechtsvraag tot de bevoegdheid van de Hoge Raad behoort. Omdat de materiële vraag of moraliteitsvraag van feitelijke aard is, staat deze slechts ter beoordeling aan de feitenrechter. Ze valt buiten de mogelijkheid van cassatie door de Hoge Raad. Deze beperkt zich immers tot de rechtsvraag.

In de rechtspraak vindt Van der Ley drie groepen gevallen, waarin een contract nietig kan zijn omdat de inhoud (het doel, de oorzaak) immoreel is en daarom in strijd wordt geacht met de goede zeden. Dat kan het geval zijn 1) als het onderwerp van de overeenkomst immorel is, 2) als niet het onderwerp zélf, maar het opnemen ervan in een contract (met rechtsdwang) immoreel is en 3) als de immoraliteit van het contract blijkt uit het onzedelijk verband tussen de prestatie van de ene partij en de tegenprestatie van de andere partij. In een vierde groep gevallen gaat het om het gevolg van het uitvoeren van de contractsinhoud, datgene wat partijen beogen.

Als een van de genoemde vier typen van gevallen zich voordoet, kan formeel gesproken de overeenkomst als immoreel in strijd zijn met de (openbare orde en) de goede zeden. Bij de wraag of dat feitelijk zo is, komen we bij de materiële zedelijkheidsvraag terecht. Ten aanzien daarvan betoogt Van der Ley dat de rechter zich uitsluitend te houden heeft aan de moraal van het heden. Hij dient geen rekening te houden met moraal van het verleden of de toekomst. Uit de rechtspraak kan tot op zekere hoogte blijken wat de moraal van het heden inhoudt. In het Nederlandse contractenrecht van zijn tijd is volgens Van der Ley slechts een laconieke, praktische moral te vinden. Slechts een ál te exorbitante contractsvrijheid wordt daardoor belemmerd. Ernstige bedreiging van leven, gezondheid en eerbaarheid kan bijvoorbeeld wel in strijd zijn met de goede zeden, maar dat kan zeker niet als regel zonder witzondering worden gezien. Contracten "waarbij leven, gezondheid en eerbararheid in gevaar zijn van arbeiders en werkvrouwen, gelijk bij zekere chemische indusirieën (loodwit en chloorkalk-fabrieken) worden geldig geacht." ${ }^{\text {"23 }}$ Het ziet er volgens Van der Loy wél (in 1899) naar" uit, dat of "over niet lange tijd, zowel de geldwoeker als het uitzuigingscontract doorlopend geacht worden in strijd te zijn met de goede zeden, of dat er wettelijke regeling omirent dit onderwerp zal ontstaan." ${ }^{24}$ Hij laal daar echter meteen nog eens de warschuwing op volgen, dat de toekomstige moraal de rechter vooralsnog onverschillig moet zijn. Slechts de tegenwoordige moraal mag van invloed zijn.

24 Van der Ley 1899, p. 82. 
In zijn proefschrift uit 1920 over overeenkomsten in strijd met de goede zeden acht Petit $^{25}$ het begrip openbare orde niet overbodig. Hij ziet echter geen zelfstandige betekemis voor elk van de beide begrippen openbare orde en goede zeden. Volgens Petit vormen ze samen één uildrukking, "goede zeden doet meer denken aan een ethische waardeering, openbare orde meer aan de onaantastbaarheid van de maatschappelijke ordening; waar in wetsbepalingen slechts een van deze termen is gebezigd, wordt in den regel niets anders bedoeld als wat de beide uitdrukkingen te zamen onvatten." ${ }^{26}$

In tegenstelling tot Van der Ley betoogt Petit, tegen de dan nog heersende leer in, dat de goede zeden rechtsinhoud hebben. Hij verwijst naar de Hoge Raad, die doende is zijn toetsingsrecht op het gebied van ongeschreven rechtsnormen uit to breiden. Daarbij vormen normen waarnaar met "goede zeden" verwezen wordt de belangrijkste categorie buiten de wet te vinden rechtsregels. In de goede zeden kan de rechtswaarde van maatschappelijke belangen als economische vrijheid, goede trouw in het maatschappelijk verkeer, behoorlijke nakoming van overeenkomsten, sexuele en lichamelijke integriteit tot uitdrukking komen. Petit wijst in dit verband ook op de dan recente nieuwe interpretatie van artikel 1401 oud BW, betreffende de onrechtmatige daad. Volgens het arrest van 31 januari 1919 van de Hoge Raad, NJ 1919 p. 161, in de zaak Lindenbaum/Cohen, bepalen ook de regels van "maatschappelijke betamelijkheid en zedelijkheid" het begrip "onrechtmatig". De maatschappelijke gedragsregels waar de wet met de "goede zeden" naar verwijst, worden dan niet meer opgevat als feiten waaraan de rechter geen rechtsoordeel zou kunnen ontlenen. Een beroep op nietigheid van een overeenkomst op grond van strijd met de goede zeden is in cassatie een middel "van openbare orde" en daarmee een ambtshalve door de rechter te onderzoeken rechiswraag. ${ }^{27}$

Zoals we dat eerder bij Van der Ley en ook al in het vorige hoofdstuk hebben gezien, is ook bij Petit een verwijzing naar positieve en negatieve werking van het openbare orde en goede zeden begrip te vinden. Petit legt er de nadruk op dat de formule strijd met de openbare orde en goede zeden in het contractenrecht gelijkijdig de beide functies kan onvatten. De negatieve, afwerende functie werkt als een beknotting van de contractsvrijheid. Tegelijk kan deze beknotting de positieve functie hebben van bescherming van vitale rechtswaarden, waronder de contractsvrijheid zelf.

Dat contractswijheid als uiting van private autonomie de zedelijke kem is van het contractsbegrip, correspondeert met wilsovereenstemming van partijen als juridisch vereiste voor het ontstaan van een overeenkomst. Die komt tot stand door wederzijdse instemming die erop gericht is een bepaald gewild rechtsgevolg te weeg te brengen. Daarmee heeft de vrijheid on te contracteren betrekking op meér aspecten dan alleen op de wilsovereenstemming ten aanzien van het ontstaan van het contract. Ze betreft ook de vrijheid om zélf de inhoud van het contract te bepalen en de vorm warin het wordt aangegaan. Naarmate het

25 Ch.J.M. Petit, Owereenkomsten in strijd met de goede zeden, Leiden 1920.

26 Petill 1920, p. 62-63.

$27 \mathrm{Vgl}$. P. Abas, Beperkende werking van de goede trouw, Deventet 1972, p. 96 v, over de ontwikkcling van redelijkheid en billijkheid wan feitelijke vraag naar rechtswrabs, sinds 1923 waste jurisprudentie wan de Hoge Raad. 


\section{Hoofdstuk 6}

vrijheidsgehalte van één of meer van deze aspecten in het gedrang komt, verliest de zedelijke factor wam de gebondenheid aan het zelf gegeven woord in het contractenrecht aan betekenis. ${ }^{28}$

Het uitgangspunt van de contractsvrijheld, dat partijen zich ten aanzien van het tot stand komen, de inhoud en de strekking van een overeenkomst economisch en maatschappelijk in cen gelijkwaardige positie bevinden, strookt vaak niet met de realiteit. Naarmate dit besef een breder draagvlak heeft gekregen, zijn pogingen gedaan tot het keren van machtsmisbruik en is de roep om sociale wetgeving luider geworden. Dit heeft geleid tot steeds sterker en grootscheepser ingrijpen in de contractsvrijheid door de overheid. Maar naarmate dat gebeurt komt het zedelijk beginsel van gebondenheid aan het zélf gegeven. woord als kern van het contractsbegrip onder druk te staan. Daarmee zijn we bij het probleem van het gelijktijdig en evenwichtig waarborgen van private en publieke autonomie van burgers in een sociale en democratische rechtsgemeenschap.

Naarmate het juridisch ingrijpen in de contractsvrijheid op bepaalde gebieden van het recht meer gebeut in de vorm van sociale wetgeving, zoals in het arbeidsrecht en in het pachten huurrecht, is op die via de formule van strijd met de openbare orde of de goede zeden. Zoals we dat in het vorige hoofdstuk hebben gezien bij de ontwikkeling van voorrangsregels in het ipr, neemt in het contractenrecht sociale wetgeving geleidelijk een gedeelte van de functie van het openbare orde en goede zeden begrip over. ${ }^{29}$ Daarnaast ontstaan nieuwe algemene leerstukken die een deel van de doorwerking van moraal in het recht overnemen. Een voorbeeld daarwan is "misbruik van omstandigheden", een leerstuk dat direct voortvloeit uit het openbare orde en goede zeden begrip. ${ }^{30 .}$

Het onder de noemer strijd met de goede zeden in de rechtspraak ontwikkelde leerstuk van misbruk van omstandigheden was onder het regime van het oud BW slechts bij overeenkonnsten aan de orde. In het nieuw BW is misbruik van omstandigheden een algemene grond voor vernietiging van vermogensrechtelijke rechtshandelingen. Misbruik van omstandigheden is aanwezig, wanneer iemand die weet of moet begrijpen dat een ander door bijzondere omstandigheden, zoals noodtoestand, afhankelijkheid, lichtzinnigheid, abnormale geestestoestand of onervarenheid, bewogen wordt tot het verrichten van een rechtshandeling, het tot stand komen van die rechtshandeling bevordert, ofschoon hetgeen hij weet of moet begrijpen hem daarvan zou behoren te weerhouden (artikel 3:44, lid 4 BW). Deze uilvoerige wettelijke uitwerking van de rechtsfiguur misbruik wan omstandigheden is een mooi yoorbeeld van het uitkristalliseren van morele beginselen via de openbare orde en goede zeden. Dat het begrippenpaar openbare orde en goede zeden zélf daarmee miet juridisch uitgewerkt is, blijkt uit de uitbreiding in het nieuw BW van de figuur vann nietigheid bij strijd met de openbare orde en goede zeden tot alle rechtshandelingen. Maar

28 Vgl J.H. Beckuis, Contract en contractsvrigheid, rede, Groningen, Djakarta 1953.

29 zie over bescherming wn de zwakkere partij als "enige geheel newwe gerechtigheidsgedachte die zich hat het lot stand komen van het oude wetboek in ons burgerlijk vermogensrecht een plaats heeft veroverd": G.E. Langemeijer, De yereclatigheid in ons burgerhijk vermogensrech, wijde herziene drak, Zwolle 1985, p. 86 v.

30 Vgl J.M. van Dunné, Verbintenissenrecht in ontwikkeling, Deventer 1987, p. 57 v. 
het begrippenpaar openbare orde en goede zeden heeft niet het monopolie van doorwerking wan moraal in het contractenrecht. De verhouding tot andere open rechtsnormen komt in de laatste paragraaf aan bod. Eerst wil ik in de volgende paragraaf Nieuwenhuis" "Drie beginselen van contractenrecht" vergelijken met drie beginselen van mensenrecht.

\section{Drie beginselen van contractenrecht en drie beginselen van mensenrecht: een vergelijiking}

Nieuwenhuis betoogt dat de verbindende kracht van overeenkomsten berust op drie beginselen: het autonomiebeginsel, het vertrouwensbeginsel en het causa-beginsel." Contractspartijen zijn bevoegd om desverkiezend rechtsbetrekkingen aan te knopen: een verwijzing naar het autonomiebeginsel. Het in dat kader opgewekt vertrouwen verdient bescherming: een verwijzing naar het vertrouwensbeginsel. De door de overeenkomst in het leven geroepen verbintenissen zijn van elkaar afhankelijk. Ze staan over en weer in een middel/doel-relatie: een verwijzing naar het causalseginsel. Als de contractswrijheid wordt gezien als een mensenrechtelijk perspectief van private autonomie, dan is de vraag in hoeverre Nieuwenhuis' drie beginselen van contractenrecht sporen met drie beginselen van mensenrecht.

Als rechtvaardiging van de verbindende kracht wan de overeenkomst hebben drie beginselen van contractenrecht een dubbele basis. Zij wortelen in de maatschappelijke werkelijkheid (de "realia" van het recht) én in de waarden die een samenleving tot leidraad heeft gekozen (de "idealia" van het recht). In een open proces van rechtsverwerkelijking werken rechtsbeginselen als sluizen waardoor de invloeden van de matschappelijke werkelijkheid (realia van het recht) en van het waardenpatroon dat de rechtsgemeenschap tracht te verwezenlijken (idealia van het recht) het positieve recht binnen stromen, aldus Nieuwenhuis. ${ }^{32}$

Als realia van het contractenrecht beschrijft Nieuwenlzuis vertrouwen, zekerheid, wederkerigheid, de overgang van "Gemeinschaft" naar "Gesellschaft" en institutionalisering. ${ }^{33}$ De realiteitsbasis van vertrouwen, zekerheid en wederkerigheid wortelt in de economische orde van een samenleving. Met "Gemeinschaft" en "Gesellschaft" zijn uiteenlopende typen sociale betrekkingen bedoeld. Gemeinschaft drijt op gevoelde saamhorigheid (in familieverband bijvoorbeeld). Gesellschaft drijt op samenwerking op grond van beredeneerd eigenbelang. Overeenkomst als vorm van samenwerking is een noodzakelijke voorwarde voor een arbeidsdeling die de grenzen van gevoelde saamhorigheid overschrijd. Institutionalisering omschrijft Nieuwenhuis als de vorming van traditionele patronen van samenleving. Instituties zijn iets als "recepten" die dienst doen ter verlichting van de constante keuzedwang waarwoor mensen zich geplaatst zien. Om hun werk te kunnen doen moeten deze recepten soepel genoeg zijn om menselijke creativiteit niet volledig de kop in te

33. Nieuwe nhuis 1979, p. 47 \% 


\section{Hoofdstuk 6}

drukken. In het contractenrecht beschouwt Nieuwenhuis institutionalisering als tegenhanger van de will wan partijen.

Onder de idealia wan het recht rangschikt Nieuwenhuis in de eerste plaats vrijheid en verder rechtvaardigheid, gelijkheid en lotsverbondenheid. ${ }^{3.4}$ Vrijheid beschrijft hij in twee aspecten: het aspect van niet-inmenging door anderen en dat van zelf-ontplooiing. Bij rechtvaardigheid en gelijkheid gaat het er om, gelijke gevallen gelijk te behandelen en ongelijke gevallen ongelijk naar de mate van het verschil. Deze formele categorieên moeten ingevuld worden met behulp van een materieel criterium dat de neerslag vormt van het waardensysteem van een samenleving. Als een extern en onafhankelijk criterium ontbreckt, komt het volle gewicht op de procedure te liggen krachtens welke een criterium wordt vastgesteld. ${ }^{35}$ Evenwicht in het onderhandelingsmechanisme en een gelijkwaardige positie van partijen wormen de beste garanties voor een evenwichtig resultaat, voor ruifrechtvaardigheid, aldus Nieuwenhuis. Met "lotsverbondenheid" als ideële factor bedoelt hij de verwevenheid van contractuele verplichtingen. Deze vormen als het ware ellkaars "oorzaak", elkaars "fundament". ${ }^{36}$ Het idecel aspect van het vertrouwensbeginsel vat Nieuwenhuis samen in het ethisch postulaat "een man een man, een woord een woord."

Als we nu drie beginselen van contractenrecht nog eens bekijken, dan is daar om te beginnen het autonomiebeginsel. Dat staat in het teken van het vrijheidsaspect zelfontplooiing. Naast een individuele dimensie heeft zelf-ontplooing in de visie van Nieuwenhuis ook een sociale dimensie. In het contractenrecht gaat het met name om de sociale dimensie van zelf-ontplooiing. Voor het realiseren van hun levensplannen zijn mensen door alle tijden heen mede aangewezen op samenwerking met anderen. Het contract is een instrument om aan deze samenwerking gestalte te geven op basis van wederkerigheid. "Contractsvrijheid, de mogelijkheid on desverkiezend rechtsbetrekkingen aan te knopen, is niet slechts een ideaal (zo men wil ideologie) van het 19e-eeuwse liberalisme, zij wortelt tevens in de feitelijke, biologische geaardheid van de mens.,"3. Geconstateerd kan worden dat het autonomiebeginsel aansluit bij vrijheid als beginsel wan mensenrecht, in de dimensie van private autonomie.

Als tweede beginsel van contractenrecht stelt Nieuwenhuis het vertrouwensbeginsel voor. Gerechtvaardigd vertrouwen verdient bescherming, alldus Nieuwenhus. In mijn optie voor een gespreksmodel wan recht wordt het beginsel "tronw" primair ingevuld als "betrouwbatarheid" in de betekenis van het instaan voor het eigen woord. In Nieuwenhuis" leer is dat het idedle aspect van het vertrouwensbeginsel. Het is de verdienste van Nieuwenhuis dat hij de ideb̈le en de reele basis van het vertrouwensbeginsel duidelijk naast elkaar zet. "Een overeenkomst is soms gellig, ondanks de omstandigheid dat de ene contractant die

34 Nienwenhuis 1979, p. $52 \%$

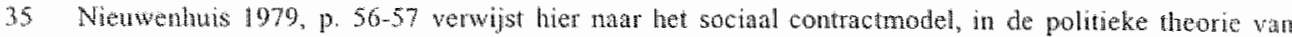
Jom Rawis.

36 Niwwenhuis 1979, p. 59, verwist nad HR 17 april 1914, NJ 1914668.

37 Nicuwabuis $1979,0.42$.

38 Nenwenhus 1979, p. 46-47 verwijst in dit verband mat Konrad luorene, dic spreekt over de mens als "das unfertige Wesen" dat gedwongern is zijn levensplan in viiheid te kiezen. 
gebondenherd niet werkelijk wilde, op grond van het gerechtvaardigd vertrouwen van de wederparti" 39 Gerechtvaardigd verirouwen omvat ook in mijn visie zowel het idede aspect van betrouwbarheid als het reele aspect van het rechtens dragen van de consequenties van (de schijn van) betrouwbaaheid. Daamee komt de invulling van het vertrouwensbeginsel als beginsel van contractenrecht overeen met trow als beginsel wan mensenrecht.

Resteert aan de ene kant het causabeginsel, aan de andere kant het beginsel zorg. Volgens Nieuwenhuis vormt het causabeginsel op twee wijzen tegenwicht ten opzichte van het autonomiebeginsel. De volwaardigheid van de autonomie is niet voldoende om de geldigheid wan het contract aan te nemen. De onvolwaardigheid wan de autonomie is niet voldoende om het contract ongeldig te verklaren. Hij spreekt in dit verband over de "lotsverbondenheid" van de over en weer bedongen prestaties. Hienuit valt een zodanige zorgplicht van partijen ten opzichte van de verwevenlueid van de overeengekomen prestaties op te maken, dat deze zorgplicht de verbindende kracht van de overeenkonst mede bepaalt. Daamee ligt zorg als prijs van de contractsvijheid aan de basis van het causabeginsel en is de wergelijking compleet. Geconcludeerd kan worden dat drie beginselen van contractenrecht sporen met drie beginselen van mensenrecht. ${ }^{\$ 1}$

\section{Doorwerking van drie beginselen van mensenrecht in drie fasen: voor, tijdens en In het sluiten wan het contract}

Door de furidische constructie in het $\mathrm{BW}$ kan de rechtsfigur openbare orde en goede zeden een cruciale rol spelen bij het ontstaan van de overeenkomst. Bij de winoering van de overeenkomst speelt een andere rechtsfiguur, de goede trouw, een centrale rol. Dat voeit voont uit de bepaling van artikel 1374 lid 3 oud $\mathrm{BW}$, dat overeenkomsten "te goeder" trouw worden ten uitwoer gelegd." Volgens artikel 1375 oud BW verbindt de overeenkomsi tevens tot al hetgeen door de billijkheid wordt gevorderd. In het nieuw $B W$ is "goede trouw" vervangen door "redelijkheid en billijkheid" (artikel 6:248 BW). Een. verschil in betekenis is daamee niet beoogd. Ook tussen de temen redelijkheid on bilijkheid onderling wotdi in rechtsprak en literatuur doorgaans geen juridisch onderscheid gemaakt.

39) Nienwenhuis 1979, p. 66

40 Nieuwenturis 1979, p. 78.

41 Voor zover deze conchusie steekhoudend is, ksn Nieuswenhuis" uitgebreide toepassing op belangrigke deelgebieden tevens dienst doen als illustratie van doorwenking wan drie beginselen van mensenrecht in het Nederlandse contractenrecht. $Z$ ie Nienwenhuis 1979 , deel II

42 Zie Hijma/Othof, Compendium wan het Nederlands vermogensrechi, zesde dnuk, Deventer 1996, p. 18 over de "verbintenisrechtelijke" goede trouw, die in het NBW niet langer goede trouw maal redelijkheid en billijkhed wordt genoend (art. $6.2,6248,6: 258$ BW en de uitwerking van $3: 12 \mathrm{BW}$ ). Vgl. ook H.G. Van der Werf, Redelijkheid en billijkheid in het contractenrecht, Arnhem 1982, p. 19 met literatuuverwijzingen en Langemeijer $1985 \mathrm{p} .111 \mathrm{v}$. 


\section{Hoofdstuk 6}

De goede trouw, c.q. redelijkheid en billijkheid heeft in de fase van de uitvoering van de overeenkomst een aanvullende en een beperkende werking. De aanvillende werking dient on leemtes in het contract naar redelijkheid en billijkheid op te vullen. De beperkende werking dient als toets voor de wijze waarop de overeenkomst wordt uitgevoerd, on de contractsbepalingen niet te laten dienen "als vrijbrief voor onredelijk gedrag." Van der Werf karakteriseert de werking van de goede trouw als het slatan van een brug tussen aan de ene kant het privaatrecht als dogmatisch stelsel met eigen wetmatigheden en aan de andere kant privaatrecht als middel om tot rechtvaardige oplossing van conflicten in het maatschappelijk verkeer te komen. Daarbij richt de goede trouw zich naar haar aard telkens naar de specifieke omstandigheden van het voorliggende geval. Steeds gaat het om een evenwichtige waardering van alle bij een overeenkomst betrokken belangen. ${ }^{44}$

De goede trouw in het contractenrecht wordt ook wel onschreven als het beginsel van de contractuele zorgvuldigheid. ${ }^{45}$ Met deze koppeling van trouw aan zorg komt naar ik meen terecht ook de verplichting tot betrouwbatheid van partijen over en weer naar voren en niet alleen het vertrouwen van partijen over hetgeen zij van elkaar mogen verwachten. Met De Kluiver spreekt mij meer aan "dat men niet vraagt wat een ander van een bepaalde persoon verwacht of waarop hij vertrouwt, maar dat men de vraag stelt waartoe een persoon "te goeder trouw" gehouden is mede in verband met zijn eerdere uitspraken of handelingen gelet op de context waarin die tot stand kwamen." ${ }^{46}$ De Kluiver betoogt naar ik meen terecht dat een theorie waarin een al te grote plaats woor "vertrouwen" wordt ingeruimd ongewenst is, omdat ze geen recht doet aan de werkelijkheid, versluierend werkt en daardoor niet ongevaarlijk is. Hij ziet tweeërlei gevaren. "Enerzijds kan het vertrouwen zozeer worden geobjectiveerd dat al hetgeen men maatschappelijk wenselijk acht daaronder kan worden gevat. Anderzijds houdt een vertrouwensbegrip waarin het subjectieve vertrouwen centraal staat juist weer te weinig rekening met gerechtvaardigde maatschappelijke wensen. ${ }^{947}$

De goede trouw c.q. redelijkheid en billijkheid, gekoppeld aan een zorgvuldigheidsnorm, speelt niet alleen expliciet een rol in de fase van de uitvoering van het contract. In de huidige stand van het Nederlands contractenrecht is dat ook al in de vórfase van de overeenkomst het geval. In het negentiende eeuwse contractsbegrip was daar geen sprake wan. Dat klassieke contractsbegrip werd gekenmerkt door een strikte afbakening van vrijwillig aangegane contractuele gebondenheid in de tijd. Al hetgeen zich in de precontractuele fase tussen onderhandelende partijen afspeelde was rechtens niet relevant.

43 Vander Warf 1982, p. 14.

44. Van der War $1982, p$. 14 net verwijzingen.

45 Van der Werf 1982, p. 18 bespreekt instemmend J.M. Van Dumne, Drie beginselen van contractenrecht, ean boekbeshouwing. WPNR 5525, 1980, p. 458. Al in 1923 spreakt M.G. Levenbach, De spaning wan de kontraktsband, Amsterdam $1923, \mathrm{p} .47 \mathrm{v}$, oxer de "zorg" wan de debitean als richtsnoer bij zijh eigen gedmag in verband met de vervulling van de overeenkomst. Wgl. aver het "dubbel gebod" wan goede trouw en zorgvuldigheid in de fase die an het sluten wan het contract voorafgat H.C.F. Schoordijk, Onderhandelen te goedet troww, Deventer 1984, p. 14.

47 De Kluiver 1992, p. 37. 
Geleidelijk is in rechtspraak en literatur aandacht gegroeid voor de aan het sluiten van het contract voorafgaande fase. Precontractuele aansprakelijkheid voor onbehoorlijk gedrag wan (én van) partijen wordt niet langer uitgesloten.

Een doorbraak in het denken over aansprakelijkheid in het geval van afgebroken onderhandelingen heeft in Nederland in het begin van de jaren tachtig plaats. Het arrest Plas/Valburg van de Hoge Raad markeert deze doorbraak. ${ }^{49}$ In deze zaak wordt de met de Gemeente Valburg over de bouw wan een zwembad onderhandelende aamemer Plas door de Gemeente op het laatste moment gepasseerd. In zijn uitspraak onderscheidt de Hoge Raad meer in het algemeen twee stadia in onderhandelingen die rechtens van betekenis kunnen zijn. In beide stadia speelt de goede trouw een rol. In het eerste stadium acht de Hoge Raad de onderhandelingen nog niet zover gevorderd dat een afbrekende partij te goeder trouw deze niet meer had mogen afbreken, maar wél in een stadium dat zulk afbreken haar in de gegeven omstandigheden niet meer zou hebben opengestaan zonder de gemaakte kosten geheel of gedeeltelijk voor haar rekening te nemen. In het iweede stadium acht de Hoge Raad het niet uitgesloten dat de onderhandelingen zover gevorderd zijn dat het afbreken ervan onder de gegeven omstandigheden als in strijd met de goede trouw moet worden geacht, omdat partijen over en weer mochten vertrouwen dat enigerlei contract in ieder geval uil de onderhandelingen zou resulteren. In zo'n situatie kăn er volgens de Hoge Raad naast een verplichting tot vergoeding van kosten (eerste stadium) ook sprake zijn van een verplichting tot vergoeding van gederfde winst (tweede stadium).

Na het arrest Plas/Valburg wordl in juridische kringen intensief gediscussieerd over de vraag of een verbintenis to schadevergoeding wegens afgebroken onderhandelingen kan worden gebaseerd op de goede trouw. De lagere rechtspraak aanvaardt dit in meerdere uitspraken. De Hoge Raad spreekt zich over de grondslag van een mogelijke vordering niet duidelijk wit. ${ }^{50}$ In de Nederlandse rechtswetenschap schijnt zich een consensus af to tekenen, dat in geval van afgebroken onderhandelingen de goede trouw onder omstandigheden bron van verbintenissen kan zijn. De Kluiver sluit zich daarbij aan, maar twijfelt aan het nut van een beroep op de goede trouw. Beter dan de goede trouw kan hier volgens hem het leersuk van de onrechtmatige daad dienst doen. Dit leerstuk kan enerzijds recht doen alan de economische eis van brede oriëntering en daarmee samenhangende vrijhcid van onderhandeling. Anderzijds kan ook rechtens de woorwarde gesteld worden dat een contractspartij onder bepaalde omstandigheden schade vart de andere partij voor har rekening neemt. ${ }^{\text {s! }}$

Als naast of in plaats van de goede trouw de onrechtmatige daad in de precontractuele fase als rechtsgrond voor schadevergoeding wordt aangemerkt, wordi de matschappelijke zorg-

Zie hierover uitgebreid, ook rechtsvergelijkend, De Klwiver 1992, p. 179 w. Volgens De Kluiver, p. 187 , is Telders in 1937 (WPNR 3536/3537), de eerste die in Nederland een afzonderlijke beschouwing wijd aan de problematick van aansprakellikheid bij afgebroken onderbandelingen. HR 18 juni 1982, NJ 1983, 723. Zie hierover De Kluiver 1992, p. 234 v. Zie ook Schoordijk 1984, p. 35 en p. $61 \%$.

50 De Kluiwer 1992, p. $250 \%$.

S1 De Kluiver 1992, p. 263. 


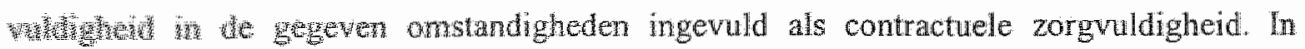

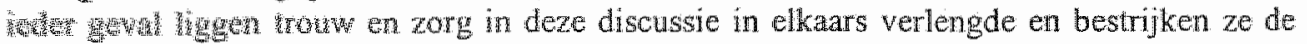

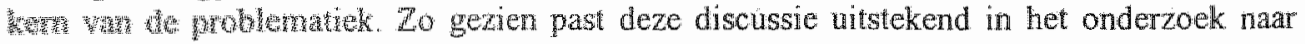

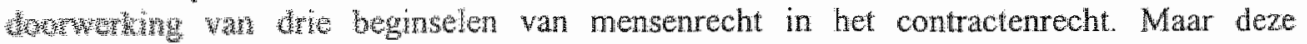

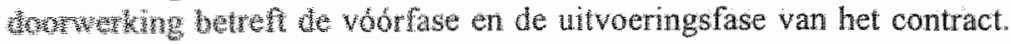

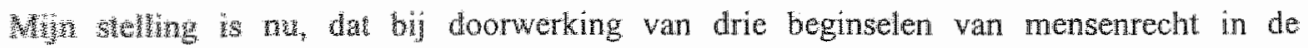

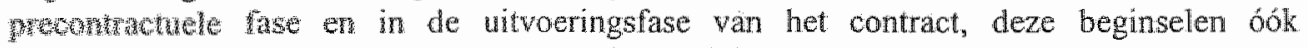
Whorwergen in de fase van de contractsluting zélf. Als deze stelling opgaat, dan kunnen ththe beginseten van mensenrecht in die fase doorwerken via de rechtsfigutr openbare orde us goede zeden. Dat de stelling opgat is te meer aannemelijk als het contract wordt

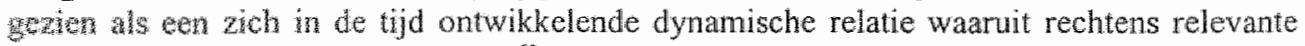
watrothetuthingen kumnen voortvloeien. ${ }^{52}$ Uitgangspunt in deze benadering is het systeem van hat wermogensrecht. Een aantal afwegingsfactoren kunnen daarbij dienst doen als richtpunterat wet vaststellen van gehoudenheid. ${ }^{53}$

Unycande wan ontwikkelingen in de Nederlandse, Engelse en Amerikaanse rechtspraak formuleert Van Erp als afwegingsfactoren: "(a) ontstane eenzijdige of meerzijdige verwachtingen; (b) eenzijdig of meerzijdig vertrouwen; (c) het voordeel dat iemand als gevolg van de ontstane verwachtingen respectievelijk het ontstane vertrouwen heeft genoten; (d) het nadeel dat iemand heeft geleden of het voordeel dat men heeft laten varen als gevolg van de ontstane verwachtingen respectievelijk het gewekte vertrouwen; (e) overeenstemming tussen de betrokkenen; (f) normen van maatschappelijke zorgvuldigheid respectievelijk redelijkheid en billijkheid; $(\mathrm{g})$ beleidsoverwegingen." ${ }^{, 54}$

Op ẻen na kunnen de genoende afwegingsfactoren teruggebracht worden tot het afwegen van betrokken belangen (factoren $c$ en d) in onderling verband en in samenhang met de werking van de achterliggende beginselen vrijheid (factor e), trouw (factoren a en b) en zorg (factor $\mathrm{f}$ ). Dat de afwegingsfactor beleidsoverwegingen ( $\mathrm{g}$ ) zonder nadere concretisering niet onder te brengen is, wijst er naar ik meen niet op dat de beginselen van mensenrecht een te beperkte reikwijdte hebben. Het wijst er met het oog op rechtsbescherming wel op dat gewaakt moet worden tegen een eerder instrumentele dan mensenrechtelijk georienteerde invulling wan beleidsoverwegingen.

Samenvattend kan gezegd worden dat drie beginselen van mensemrecht alle relevante aspecten bestrijken van een belangenafweging die past in het systeem van het Nederlandse contractenrecht. De begrippen goede trouw, redelijkheid en billijkheid en (contractuele) zorgvuldigheid brengen in ondelling verband en samenhang deze beginselen juridisch tot

52 Zie IH.M. van Erp, Contract als rechtsbitrekking, Zwolle 1990, p. 284-285. Vgl over een dynamisch systeen van verbintenissen ook Schoordijk 1984.

53 Van Erp 1990, p. 294 v. Uitgangspunt bij de wrag of in een concreet geval sprake is wan een gehoudenheid en wat daarvan de inhoud is, is HR 30 jannari 1959, NJ 1959, 548, Quint/Te Poel. Danrin verwijst de Hoge Raad nat het stelsel van de wet bij het zoeken van aansluiting bij woll in de wet geregelde gevallen. 
uitdrukking in de precontractuele fase en in de uitvoeringsfase van het contract. Het begrippenpaar openbare orde en goede zeden doet dat in de fase van het sluiten van het contract. 



\section{PUBLIEKRECHT}

\section{Inleiding}

Ook bij het bespreken van publiekrechtelijke onderwerpen ga ik uit wan samenhang tussen de juridische ontwikkeling wan het openbare orde begrip en een geleidelijk sterker wordende oriëntering op mensenrecht. In dit licht wordt ook de in het vorige hoofdstuk naar voren gekomen samenloop van een afwerende en een opleggende functie van het openbare orde begrip nader bekeken.

Als staatsrechtelijk onderwerp komt het verenigingsrecht aan bod, zoals dat sedert 1848 in de Nederlandse Grondwet staat. Deze keuze ligt voor de hand, ondat artikel 8 (grondrecht tot vereniging) het enige artikel in de huidige Nederlandse Grondwet is waarin het begrip openbare orde als beperkingscriterium ten aanzien van een grondrecht wordt gebruikt. ${ }^{1}$ Vanwege de publiekrechtelijke aard en het vanuit democratisch oogpunt vitaal belang spits ik de bespreking toe op het verenigingsrecht van politieke partijen (par. 2). Als bestuursrechtelijke onderwerpen vergelijk ik algemene beginselen van behoorlijk bestuur met drie beginselen van mensenrecht (par. 3) en bespreek ik het politiebegrip openbare orde (par. 4). Bespreking van het strafrecht, dat als specifieke bescherming van de rechtsorde als geheel "van openbare orde" kan worden beschouwd, beperk ik tot misdrijven en overtredingen betreffende de openbare orde en de zeden in het Wetboek van Strafrecht (par. 5).

\section{Het openbare orde begrip in het verenigingsrecht van politieke partijen ${ }^{2}$}

In 1848 wordt het verenigingsrecht samen met het recht tot vergadering in artikel 10 van de Grondwet opgenomen: "Het regt der ingezetenen tot vereeniging en vergadering word erkend. De wet regelt en beperkt de uitoefening van dat regt in het belang der openbare

1 Sedert 1983 staan de rechten tot vergadering en betoging als koppel in artikel 9 Grondwet. Voorheen werden de rechten tot wereniging en wergadering in éen adem genoend en was het rech van beloging niet in de grondwet opgenomen. In hes huidige artikel 9 Grondwet is tert aanzien wan de rechters wan vergadering en betoging de beperkingsfortule "in het belang van de openbare orde" verengd tot "fer bestrijding of voorkoming wan wanordelijkheden". Ten aanzien van bet recht tot wereniging, daf sedtert 1983 in antikel 8 Grondwet stat, is dat niet gebeurd.

2 In deze paragaaf magk ik gebruk wan het proffschift wan J.A.O. Eskes, Repressie van politioke bewegingen in Nederland, Een jurisch-historische studie ower het Nederlandse publiekrechelijke verenigingstech gedurende het tijdvak 1798 1988, 2wolle 1988 . Zie ook mijn recensie van dit proefschrift in Publiek Domein 1989, p. 337-340. 
orde." Het artikel betreft zowel verenigingen van privat- als van publiakrechelige aad. Tijdens de parlementaire behandeling van aen in 1850 ingediend ontwerp van cen witworingswet word de openbare orde formule in het grondwetsartikel gehekeld vanwege da zeer ruime beperkingsmogelikheid. "Het artikel had schrik en angst verwekt. Waarom? Omdat het recht van vereniging en vergadering daarbij erkend werd. (..) Ziet gij dan nien dat de tweede zinsnede de cerste wegcijfert? Dat de gewone wetgever geheel vrij blijf, on te nemen niet alleen repressieve, maar ook preventieve maatregelen; in het belang, dat is, voor het nut, der openbare orde; dat met die tweede zinsnede elk dwangmiddel verdedig. baan is."

Wa het mishkken van het eerste onwerp uitvoeringswet is in een nieuw ontwerp (1854. 1855) het oprichten van verenigingen vrij: "Tot de oprigting eener vereeniging wordt geene magtiging gevorderd." (artikel 1). Volgens artikel 2 is de vereniging die strijdig is met de openbare orde verboden. In artikel 3 wordt met de openbare orde strijdig geacht eke verenging welke tot doel heeft: "1) ongehoorzaamheid aan of overtreding van de wet of eene wethelijke verordening; 2) aanranding of bederf der goede zeden; 3) stoomis in de uitoefening der regten, van wie het ook zij. "Volgens artikel 4 wordt deelnening aan een verboden vereniging strafbar verklaard, als strijdig met de openbare orde. "Over dit repressief stelsel ten anzien van verboden verenigingen, dat in handen van de strafrechter wordt gelegd, is het parlement tevreden.

Het in het wetsontwerp opgenomen rechtspersoonlijkheidsregime krijgt forse kritiek. Een van de punten van kritiek richt zich op de maatstaf die gehanteerd moet worden bij het weigeren var de rechtspersoonlijkheid: "gronden ontleend aan het algemeen belang." Gevreesd wordt dat dit zeer tuim weigeringscriterium in handen van de bestuurlike overheid kan leiden tot willekeur bij het beperken van het recht van vereniging als politiek grondnecht: Ondanks deze kritick wordt het ontwerp in het parlement aanvaard. De regeling gaat de geschiedenis in als Wet van 22 april 1855 (\$.32) tot regeling en beperking der uitoefening van het regt wan vereeniging en vergadering (WVV).

3 Zie over artikel 10 Grondwet 1848 en de datop gebaseerde Wet Vereniging en Vergadering 1855 ook hoofdstituk 5 , par. 3.

4 Op éch uitzondering nith - artikel 18 wan de Statatstegeling voor de Batalsche Republiek wan 1798 . heeft de Nederlandse wetgever er steeds van afgezien regelingen tot stand te brengen die exclusief gerich zijn op politieke partijen. De op artikel 18 van de Statsregeling 1798 gebaseerde strafbepa. lingen tegen "verstoorders wan de publicke rust" geven strafmodaliteiten als strenge geseling, brand. mek, gevangenisstraf, verbaming en doodstraf. Deze regeling was geen lang leven beschoren. De Statstegeling van 1801 laat elke regeling betreffende het verenigingsrech achterwege. Eskes $1988 . \mathrm{p}$. 11.

Handelingen II 1850.1851, p. 1138 rechter kolom (Groen van Prinsterer). Minister wan bimenlandse zaken is Thorbecke. Fskes 1988, p. $29-43$.

Defimitieve tekst, wa enkele wijzigingen, zie H II 1854-1855, p. 63, p. 323, p. 556-557. Eskes 1988, p. 33. Zie ook hfdst. 5. par. 3.

7 Deze strafbepaling is later ondergebracht in artikel 140 van het Wetboek van Strafrecht.

De door Thorbecke en anderen gesignaleerde mogelijkheid van willekeur is in de praktijk herhaldelijk werkelijkheid geworden. Zie over toepassing van de WVV in de periode 1855-1930 Eskes 1988, p. $45-88$. 
Het reclatspersoonlijkheidsregime in de WVV blijkt inderdaad te werken als een instrument waarmee het overheidsbestuur staatsgevaarlijk geachte en andere ongewenste verenigingen het leven moeilik kan maken, terwill de verbodenverklaring als zwaarste middel vermeden kan worden. Toch werkt het openbare orde begrip uit het verbodsregime door in het algemeen belang criterium bij het weigeren van de rechtspersoonlijkheid. De redenering loopt als volgt. De bestuurlijke overheid ziet het als haar plicht om een vereniging die "gevaar in zich sluit woor de openbare orde en goede zeden" de rechtspersoonlijkheid te weigeren "op gronden ontleend aan het algemeen belang."

In 1939 wordt de WVV aangescherpt. In de periode van 1855 tot 1939 wordt het zwaarste middel, verbodenverklaring, maar één keer ingezet. Dat is in 1894, in het geval van de Sociaal-Democratische Bond (SDB). ${ }^{10}$ Daarbij geven rechterlijke instanties blijk van grote terughoudencheid in de omgang met het verbodsregime. "Na meerdere terugverwijzingen wordt het doel van de SDB tenslotte strijdig geacht met de openbare orde als dat zonneklaar blijkt uit een door de partijleden goedgekeurde resolutie. Daarin verklaart de SDB een revolutionaire partij te zijn die "de omverwerping der bestaande matschappelijke orde beoogt met alle hare ten dienste staande onwettelijke of wetrelijke, vredelievende of gewelddadige middelen." 12 Naar aanleiding van het SDB-verbod maakt Eskes attent op een krachtig argument om de verstrekkende beslissingsbevoegdheid betreffende het verboden karakter van verenigingen toe te wijzen aan de rechter. Het betreft het argument dat bestuurlijke onregelmatigheden die wij tegenwoordig als strijdig met algemene beginselen van behoorlijk bestuur zouden aanmerken, niet gecorrigeerd zouden kunnen worden door enig systeen van rechterlijke controle. "Bestuurlijke beslissingen waren - voor zover niet (in zeldzame gevallen) in administratief beroep was voorzien - in de negentiende eetuw volstrekt onaantastbaar." 13

Met het oog op het dreigende gevaar van het nationaal-socialisme ${ }^{14}$ stelt Van den Bergh in 1936 de principiële kwestie aan de orde van "partijen, die witsluitend met wertige middelen aan de democratie een einde willen maken (...), om dan door wijziging van wet en Grondwet onze democratische staat in een dictatoriale te veranderen." Hij baseert zijn verwerping van de "relativistische" of "waardevrije" democratie-opvatting op "één fundamenteel en principieel werschil tussen democratische on niet-democratische partijen: de laatste categorie streeft naar die ene beslissing, die de democratie haar mogelijkheid van "zelfcorrectie" ontneemt en dan gaat het on de beslissing, die de democratie zelf opheft." 16

Het betref de weigering van de rechtspersoonlijklieid aan de Nieuw-Malthusiansche Bond bij Ministeriele beschikking van 4 juni 1927, WhR, 11666, p. 4. Zie hitrover Eskes 1988, p. 82-86.

10 Al in 1884 was de $S D B$ de rechtspersoonlijkheid geweygerd. Eskes $198.8,0,46 \%$

11 Zie bij woorbeeld Hof Arnhem, 5 mei 1893 , WhaR 6334; Eskes 1988, p. 51 .

12 Tekst weergegeven in uilspraak HR 3 december 1894 , WhR 6585, wskes 1988, p. 49/50

13 Eskes 1988, p. 55 .

14 Zie over de jaren dertig Eskes 1988 , p. 89.282

15 G. van den Bergh, De democratische Stat en de nietedemocratische parijen, Inangurele rede (Uniw. Ansterdam), 1936, p. 6, Eskes 1988 , p. 249.

16. Van den Bergh 1936, p. 6; Eskes 1988, p. 249. 
Op zoek naar mogelijkheden om op te treden tegen niet-democratische partijen komt Van den Bergh bij het tweede punt van de onschrijving van het openbare orde criterium in artikel 3 van de WVV 1855: cen doel dat gericht is op "aanranding of bederf der goede zeden". "Dit verbodsmotief kan volgens hem de rechtsgrond opleveren om fundamentele zedelijke beginselen - hij noemt de vrijheld van godsdienst en levensovertuiging en het beginsel van gelijkheid woot de wet - via het openbare orde criterium te laten doorwerken. Door het negeren van de eerbied voor de persoonlijkheid van ieder mens bedreigt de dictatuur-gedachte van niet-democratische partijen in zijn opvatting elk van deze drie zedelijke beginselen.

In een in 1939 doorgevoerde wijziging van de WVV ${ }^{18}$ wordt het juridisch instrument van de verbodenverklaring aangescherpt. In de nieuwe opzet zit de verbodsbeslissing niet meer in een rechtsoverweging van de strafrechter, maar krijgt ze zelfstandige betekenis, als een declaratoire beschikking van de burgerlijke rechter. Op basis daarvan kan dan eventueel een strafvervolging tegen deelnemers aan de verboden vereniging worden ingesteld. In de aanhef van artikel 3 WVV komt een toevoeging. ${ }^{19}$ Naast het doel mag nu ook de feitelijke werking van de vereniging niet strijdig zijn met de openbare orde ${ }^{20}$ In de volgende opnerking in de Memorie van Toelichting is bevestiging te vinden voor een oriëntatie aan fundamentele zedelijke beginselen, zoals door Van den Bergh bepleit. "Het wezenlijke in de rechtsstaatgedachte is: dat de Staat zelf rechten erkent, die aan zijn bevoegdheid voorafgaan, en dat ook hij zich gebonden weet aan hoogere normen, zoodat het positieve recht niet is product van den wil van den wetgever alleen".".

In de periode na de tweede wereldoorlog tot 1976 wordt de WVV met het oog op aanpassing an de internationale rechtsorde twee maal gewijzigd. ${ }^{22}$ Een in 1968 ingediend wetsontwerp betreft het verbodsregime en houdt verband met het Verdrag van New York van 7 maart 1966 inzake de uitbanning van elke vorm van rassendiscriminatie. ${ }^{23}$ Waar in dit wetsontwerp voorgesteld wordt om praktisch alle vormen van rassendiscriminatie strafbaar te stellen ${ }^{24}$ lijkt aanpassing van artikel $3 \mathrm{WVV}$ overbodig. De verbodsgronden

17 Van den Bergh 1936 , p. 19; lakes 1988, p. 250.

18 Wet van 13 mei 1939 , S. 200.

19 Op tocvocgingen an artikel 3 die de Tweede Kaner als van "conjuncturele aard" beschouwde ga ik hier aief in. Het gat om butenlandse bindingen van Nederlandse politieke partijen. Voor clit deel wan de wijziging werd een werkingsdur tot 1 januari 1944 in de wet vastgelegd. Juist die "vreemdelingen", dio men met deze bepalingen uit de Nederlandse politiek wilde weren, hadder bimnen een jart wh he inwerkingtreden van de wett de mach!", aldus Eskes 1988, p. 278.

20 Deze verscherping en uitbreiding van de bestaande verbodsnom gaat een stap verder dan de jurisprudentie in die tijd. Daarin wass al vastgelegd dat een "doel" ook als "feitelijk doel" kon worden vastgesteld an de hand wan de "werkeanheid" wan een associatie. Zie al HR 11 januari 1909, WwhR 8797 (Club International de Bienfaisance); Eskes 1988, p. 266.

21 H II 1977-1938, 475.3, p. 3; Eskes 1988, p. 263-264.

22 De eerste wijiging (Wet van 10 december 1964, S. 42) betreft het rechtspersoonlijkheidsregime en is bedoeld om te voldoen an het "Verdrag van San Francisco" over wakerenigingsrech, goedgekeurd bij wet wan \& december 1949. Stb. I 538 . Eskes 1988 , p. 378 v.

23 H II $1967-1968,9724,1-2$. Eskes 1988, p. 383 w

24 Zie daarover hierna parr. 5 . 
overtreding van de wet of aantasting of bederf der goede zeden lijken immers alle vormen van rassendiscriminatie via het openbare orde criterium te kunnen opvangen. Mede met het oog op het internationaal forum bestaat echter behoefte aan duidelijkheid. Bij Wet van 18 februari 1971, $\$ .96$, wordt als vierde verbodsgrond aan artikel 3 WVV toegevoegd: "het bedrijven, in stand houden of bevorderen van discriminatie van mensen volgens hun ras." Voor een omschrijving van discriminatie wordt verwezen naar het Wetboek van Strafrecht." ${ }^{25}$

In 1976 wordt het hele verenigingsgedeelte van de staatsrechtelijke WVV overgeheveld naar het nieuw $B W$, "een cruciaal moment in de geschiedenis van ons publiekrechtelijk verenigingsrecht en in het bijzonder van het verbodsregime."27 In de privaatrechtelijke sfeer waarin de herziening van het Burgerlijk Wetboek wordt behandeld, komt de in de WVV sedert 1939 geregelde declaratoire uitspraak van de verbodenverklaring te vervallen. Het openbare orde criterium overleeft de verhuizing van de WVV naar het BW. Artikel 15 van het in 1976 ingevoerde boek 2 BW luidt: "Een rechtspersoon is verboden, wanueer haar doel of werkzaamheid in strijd is met de openbare orde of de goede zeden."

De behoefte aan een eerste toepassing van het nieuwe verbodsregime op een politieke partij laat niet lang op zich wachten. Het betreft de grof op racistische gevoelens inspelende Nederlandse Volks-Unie (NVU). ${ }^{28}$ In december 1977 vordert de officier van justitie bij de Rechtbank in Amsterdam ontbinding van de NVU wegens de verboden aard van de partij, waarvan het doel enfor de werkzaamheid in strijd is met de openbare orde en/of de goede zeden. Bij beschikking van 8 maart $1978^{20}$ wijst de Rechtbank Amsterdam de vordering tot ontbinding af. De Rechtbank aarzelt niet de NVU in een rechtsoverweging als een verboden vereniging te kwalificeren. Een ontbinding alleen van de NVU mist volgens de Rechtbank echter elke betekenis, nu de NVU zo nauw verbonden is met de "Stichting tot Steun en Toezicht op de Nederlandse Volks-Unie" dat de rechten en verplichtingen van de NVU uitsluitend aan deze stichting toekomen. De Hoge Rad oordeelt dat de overweging van de Rechtbank over het verboden karakter van de NVU, anders dan de Rechtbank meent, rechtens geen consequenties heeft. ${ }^{30}$ Met deze uitspraak van de Hoge Raad is de totale mislukking van de justitiele actie tegen de racistische NVU een feit.

De ongelukkige NVU-uitspraak wordt aanleiding voor een wijziging van het verbodsregime in het $\mathrm{BW}$. Een daartoe in 1982 door minister van justitie De Ruiter aan de Tweede Kamer aangeboden wetsontwerp (17476) wordt buitengewoon slecht ontwangen."

25 Ant. 3, tweede lid WVV, jo art. 90quater WwS. Zie ook hiema par. 5.

26. Wet van 8 april 1976, S. 229 .

27 Eskes 1988, p. 414. Op p. 411-435 geeft bij zen uigebreid juridisch-fistorisch overzicht wan de totstandkoming van boek $2 \mathrm{BW}$, aok over de schernutselingen ower privat- of publiekrechtijke inbodding van het verenigingsrecht.

31 Over de reparatie wan het verbodsregime in het BW (1982-1988) Eskes 1988, p. 481.564. 


\section{Hoofdsiuk 7}

Maar in de op 13 november 1984 aangeboden Memorie van Toelichting geeft minister van justitie Korthals Altes aanvaardbare antwoorden op de lawine van door de Tweede Kamer gestelde vragen. Het veelvuldig verwijt van de vaagheid van de verbodsgrond "strijd met de openbare orde of de goede zeden" pareert hij door de fundamentele discussie daarover bij het tot stand komen van boek $2 \mathrm{BW}$ in herimering te brengen. "K2 "Korthals Altes kon in dit verband met instemming wijzen op de interpretatieve uitspraken van zijn voorganger Samkalden in 1953, die voor het BW-verbodsregime in vergelijking met de WVV een duidelijke verenging van het verbodscriterium hadden opgeleverd, in die zin dat het in ieder geval: a. beperkter was dan strijd met de wet en b. beperkter was dan aantasting van andermans rechten. ${ }^{n 33}$

In alinea 8 van de Memorie van Antwoord geeft de minister een nadere explicatie ten aanzien wan de verbodsgrond "openbare orde of de goede zeden", die volgens hem de kem raakt van wat met de verbodsgrond wordt beoogd. ${ }^{34}$ Naast een aantal voorbeelden geeft hij in deze passage op twee plaatsen een algemene normering van het verbodsoptreden. Het moet gaan on "handelingen die inbreuk maken op de algemeen aanvaarde grondvesten vam ons rechtsstelsel" of om "een aantasting van de als wezenlijk ervaren beginselen van ons rechtsstelsel die, indien op grote schaal toegepast, ontwrichtend zou blijken voor de samenleving." De uitleg van de minister krijgt in de Tweede Kamer praktisch volledige instemning. De grotendeels samenvallende abstracte normen hebben volgens Eskes het openbare orde-criterium in artikel 15 (thans artikel 20) boek 2 BW een vastere en duidelijkere omlijning gegeven dan het ooit eerder bezat. ${ }^{35}$

Artikel 20 boek $2 \mathrm{BW}$, zoals gewijzigd bij Wet wan 17 maart 1988 luidt: "1. Een rechtspersoon waarvan de werkzaamheid in strijd is met de openbare orde, wordt door de rechtbank op vorclering van het openbaar ministerie verboden verklaard en ontbonden. 2. Een rechtspersoon waarvan het doel in strijd is met de openbare orde, wordt door de rechtbark op vordering van het openbaar ministerie ontbonden. Alvorens de ontbinding uit te spreken kan de rechtbank de rechtspersoon in de gelegenheid stellen binnen een door haar te bepalen termijn zijn doel zodanig te wijzigen dat het niet meer in strijd is met de openbare orde."

Met het schrappen wan de woorden "of met de goede zeden" in de verbodsbepaling in het BW wordt aansluiting gezocht bij de beperkingsclausule in het grondwetsartikel. Het in artikel 8 Grondwet 1983 voorkomende begrip openbare orde omvat mede het begrip goede zeden, zo blijkt uit de beraadslagingen." Artikel 8 Grondwet 1983 luidt: "Het recht tot vereniging wordt erkend. $\mathrm{Bij}$ de wet kan dit recht worden beperkt in het belang van de openbare orde." Letterlijk genomen geeft de grondwetgever met deze tekst de wetgever tot vandaag de dag carte blanche voor de invoering van de meest ingrijpende beperkingen op

33 Fister 1988, p. $50 \%$

34. H II 1984-1985, 17476,5, p. 3.

35 Estes 1988, p. $508-509$.

36 Hadelingen $111976-1977$, p. 2201 . 
het verenigingsrecht, tot zelfs een preventief toezicht toe. ${ }^{37}$ Daarover merkt Eskes naar ik meen terecht op dat niet goed voor te stellen is dat de wetgever van deze bevoegdheid ooit nog gebruik zou (willen) maken. Maar, ook daarin geef ik Eskes geiijk, "voor het platsen van een grondrecht onder de hoge rechtsmacht van de Grondwet blijft wezenlijk dat niet afgegaan wordt op (vermoede of verwachte) intenties van de gewone wetgever."

Wat heeft de bespreking van het verenigingsrecht van politieke partijen opgeleverd voor de vraag naar doorwerking van drie beginselen van mensenrecht wia het begrip openbare orde? Mij lijkt dat de opmerking van Van den Bergh in 1936 over de eerbied voor de persoonlijkheid van ieder mens het meest pregnant de morele kem van thet beginsel vrijheid raakt. In het criterium dat de democratie haar mogelijkheid van "zelfcorrectie" niet ontnomen mag worden komen vrijheid, zorg en trouw samen: het daadwerkelijk zorgvuldig en betrouwbaar instaan voor de gelijkwaardige wrijheid van ieder in een democratische samenleving. In deze geest wordt de doorwerking wan fundamentele zedelijke beginselen in het openbare orde begrip bevestigd bij de wijziging van de WVV in 1939.

En hoe staat het met her gelijkheidsbeginsel? Wijst de uitbreiding van de wettellike omschrijving van "strijd met de openbare orde" in artikel 3 WVW in 1971 met het verbod van rassendiscriminatie niet expliciet op doorwerking van het gelijkheidsbeginsel in het begrip openbare orde? Zeker. Maar de wettelijke omschrijving van discriminatie, als aantasting van rechten van de mens en fundamentele wrijheden," bevestigt óók mijn stelling dat het bij het gelijkheidsbeginsel gaat om gelijkwaardige vrijheid, zorg en trouw (als beginselen van mensenrecht) ten aanzien van ieder. In mijn concept kornt het aspect van gelijkwaardigheid expliciet tot uiturukking in de eis van alpartijdigheid.

Het inruilen van de vier verbodsgronden wan artikel 3 WVV voor de formule "openbare orde of de goede zeden", bij de verhuizing naar boek 2 BW in 1976, past in de ontwikkelingslijn van doorwerking wan fundamentele zedelijke beginselen. Met het in aansluiting op artikel 8 Grondwet 1983 laten vervallen van de woorclen "of de goede zeden" in artikel 20 boek 2 BW (1988) kan de wettelijke erkenning van doorwerking van zedelijke beginselen in het openbare orde begrip zélf als voltooid worden beschouwd. De geschiedenis van het openbare orde begrip in hef politiek verengingsrecht laat zien dal respect voor individuele en collectieve vrijheid, waaronder ook die van politieke partijen zelf, in dit begrip steeds duidelijker op de voorgrond komt. Aspecten van zorgvuldigheid (zoals bij het uitbannen van vormen van discriminatic) en betrouwbaarheid (zoals bij het streven on halfslachtig. heid en willekeur te wermijden bij het aanpakken van niet-democratische politieke partijen) zijn daar onverbrekelijk mee verbonden.

38 Eskes 1988. p. 461 .

39 Artikel 90quater Wetboek wan Strafrecht, waanaar in artikel 3 lid 2 WVV (1971) wordl verwezen. Zie daarover ook par. 5 van dit hoofdstuk. Een opmerking in de Memorie van loeliching bij de wijziging van de WVV, dat een verbod wan rassendiscrminatie een plaats zon verdienen in de Grondwet, heef mede geleid tot de formulering wan het gelijkheidsbeginsel in artikel 1 wan de in 1983 gewijzigde Grondwet. Eskes 1988, p. 385, noot 360. 


\section{Hoofdstuk ?}

Ten aanzieji van functies van het openbare orde begrip hebben we in het ipr en in het contractenrecht gezien dat de afwerende functie van de formule "strijd met de openbare orde" niet alleen beperkend, maar ook beschermend werkt ten aanzien van vitale rechisbelangen. In het verenigingsrecht blijkt dat niet anders te zijn. Een woorbeeld van het samenvloeien wan de afwerende en opleggende functies van het openbare orde begrip is artikel 20 boek $2 \mathrm{BW}$. Als de rechtbank gebruik maakt van de mogelijkheid om een politieke partij de gelegenheid te geven haar doel zodanig te wijzigen dat het niet meer in strijd is met de openbare orde wlocien de verschillende functies van het openbare orde begrip samen in een bemiddelende, mensenrechtelijk georiënteerde beschermingsfunctie.

\section{Algemene beginselen van behoorlijk bestuur in verhouding tot drie beginselen van mensen recht}

In de eerste decennia van deze eeuw staan in een "antagonistisch vaderschap" de Amsterdamse hoogleraar Struycken en diens Leidse collega Krabbe aan de wieg wan de beginselen van behoorlijk bestuur. ${ }^{40}$ In de jaren dertig wordt de gollf van "stormachtige" wetenschappelijke aandacht voor ongeschreven normen van behoorlijk bestuur gebroken door een reactie die gericht is op beperking van rechterlijke bemoeienis met het besturr. ${ }^{41}$ Tijdens de tweede wereldoorlog is het Scheidsgerecht voor de Voedselvoorziening de eerste administratieve rechter die openlijk zijn toevlucht zoekt tot ongeschreven beginselen van bestuurlijke behoorlijkheid. ${ }^{42}$ In 1950 duikt het begrip "algemene beginselen van behoorlijk bestuur" (abbb) op in het rapport van de door de regering ingestelde Commissie van advies inzake verhoogde rechtsbescherming (Commissie-De Monchy). ${ }^{43}$ In 1952 introduceert de Kroon het begrip in de jurisprudentie, ${ }^{* 4}$ in 1954 verschijnt het in de wetgeving. In artikel 5 van de Wet administratieve rechtspraak bedrijfsorganisatie (WetArbo) worden als beroepsgronden opgenomen: a) strijd met een algemeen verbindend voorschrift, b) kennelijk misbruik van bevoegdheid, c) dat de overheid bij afweging van de betrokken belangen niet in redelijkheid tot het besluit of de handeling heeft kunnen komen of d) besloten of gehandeld heeft in strijd met enig in het algemeen rechtsbewustzijn levend beginsel van behoorlijk besturur.

In zijn in 1952 voor de Nederlandse vereniging voor Administratief Recht geschreven preadvies vat Wiarda de abbb op als "ethische tencenzen" die aan het bestuursrecht ten

P. Nicolni, Beginselen van behoorlijk bestuur, proefschifi. Amsterdam 1990, p. 11-24. Zie voor een tecensie C.J. Bax in. NSB 1991, p. 779-783. Het "antagonistisch vaderschap" betreft A.A.H. Struyckcu, Administratic of rechter, Arnhem 1910 en H. Krabbe, Administratieve Rechtsprak - Bijdrage. Gromingen 1901; De moderne Statsidee, 's-Grawenhage 1915.

41 Nicolai 1990, p. 39.52

42. Nicolai 1990, p. 54 v., beschrijt hoe dama ook de burgerlijke rechter en de Centrale Raad van Beroep "op ontdekkingstocht gaan".

43 Het woorstel van deze Commissie word later verwerkt in de Wet beroep administratieve beschikhingen (Wet-Bab, 1964). In 1976 word deze wet vervangen door de Wet administratieve rechtspraak overheidsbeschikkingen (Wet-Arob), die op har beurt in 1994 is vervangen door de Algemene wet bestunsrecht. 
grondslag لliggen. "In zijn inventarisatie van rechtsprak komt hij tot de beginselen van fair play, zorgvuldigheid, zuiverheid van oogmerk, evenwichtigheid an rechtszekerheid. Met fair play val hij de eisen samen wan een eerlijke procedure, waarin de onpartijdigheid van het bestuur en de gelegenheid voor de burger om voor zijn betrokken belangen op te komen gewaarborgd worden. Bij het beginsel zorgvuldigheid denkt Wiarda in de eerste plaats aan eisen van procedurele nauwkeurigheid en oplettendheid. In een rumere opvatting denkt hij ook aan een inhoudelik zorgvuldige afweging van belangen. Zwiverheid war oogmerk bekijkt hij aan de positieve en an de negatieve kant. De bestuurshandeling moet geticht zijn op het doel waarvoor de bevoegdheid is verleend (positien) en er mogen geen andere doelstellingen als hoofd-of nevenoogmerk in het spel zijn (negatief). Het begunsel wan evenwichtigheid ziet op evenredigheid in de verhouding tussen algemeen an bijzonder belang en op evenwichtigheid in de verhouding tussen de beslissing in het gegeven geval en die in vergelijkbare gevalten. Het rechtszekerheidsbeginsel heef volgens Wiarda de algemene strekking dat gerechtvaardigde belangen behoren te worden gehonoreerd.

In werhouding tot drie beginselen van mensenrecht is Wuarda"s fair play beginsel in eerste Ifin terug te voeren tot procedurele vrijheid (openheid en eerlijkheid van informatie en communicatie). Zijn zorgvuldigheidsbeginsel valt uiteraand onder zorg, evenals de positieve kant van zijn beginsel züverheid van oogmerk. Negatief gezien valt zuiverheid wan oogmerk met het oog op betrouwbal bestuurshandelen in de earste plaats onder trouw. Het evenwichtigheidsbeginsel is in mijn model terug te vinden in de eis van alpartijdigheid. Wiarda's onschrijumg van het rechtszekerheidsbeginsel is te beschouwen als een specificatie van het beginsel trouw, in een betekenis van stelselmatigheid van bestursbeleid en daarop gelaseerd betrouwbar bestumshandelen in het indiwiduele geval.

In de evolutie van beginselen van abbi wordt het belang van de "compenserende" functic wan deze beginselen in de sociale rechtsstaat Nederland steeds duidelijker. ${ }^{46}$ Op het niveau van bestuursbeleid leveren ze tegenwicht tegen een terugtred van de welgever. Op het niveau van het individuele geval compenseren ze het ontbreken van effectieve politicke controle op het bestur en zijn ze een aanknopingspunt bij het vorm geven aan een veranderende verhouding burger-overheid. Op zoek nat een ordenend principe voor een nieuwe systematisering van abbo bekijkt Nicolaij of het goede zin heeft om ansluiting to zoeken bij privatrechtelike beginselen wan behoorlijkheid. ${ }^{47}$ Daarbij verwijst hij naar eon benadering door Van Gerven (1983). In een aan privatrecht en publickrecht geneenschappelike onderbouw beperkt deze de beginselen catalogus tot het zorgvuldigheidsbeginsel, het everwichtigheidsbeginsel en het vertrouwensbeginsel. Daarbj spreekt hij van algemene beginselen van behoorlijk handelen. ${ }^{4 *}$ Deze benadering is in mijn op basalo beginselen gericht onderzoek witeraard interessant. ${ }^{49}$ Volgens Nicolai is het echter miet verhelderend

45. Algemene beginselen wan behoorlijk besturn, preadwezen uitgebracht door 1 . Samkaldon en $G . J$. Wiarda, Geschriften van de Vereniging voor Adninstratiof Recht XXI, Harlem 1952, p. 75. Over deze preadviezen Nicolaî 1990, p. $79 \mathrm{v}$. 


\section{Hoofdstuk 7}

on voor abbb aansluiting te zoken bij basale beginsellen. De vrag is nu, of en hoe de argumenten die Nicolai darwoor tegen Van Gerven aandraagt ook mijn concept van drie beginselen van mensenrecht raken.

Nicolai spitst zijn betoog in eerste instantic toe op het zorgvuldigheidsbeginsel. Zijn eerste argument is dat het betrekken van dit abbb op een globaal zorgutuligheidsbeginsel geen recht doet aan een in het bestuursrecht algemeen aanvand onderscheid tussen procedurele en materide aspecten van bevoegdheidsuitoefening ${ }^{50}$. Als abbb is het zorgwuldigheidsbeginsel primair procedureel georienteerd terwijl het privatrechtelijk ook aan materiêle eisen is georienteerd, aldus Nicolail. Dit argument is niet sterk. Ook Van Gerven vat het zorgvuldigheidsbeginsel als beginsel wan behoorlik handelen primair procedureel op. ${ }^{5}$ Met het oog op materiele aspecten van een redelijke en billijke afweging van alle betrokken belangen hanteert Van Gerwen het evenwichtigheidsbeginsel, als algemeen beginsel vam behoorlijk handelen. ${ }^{52}$ Bovendien is het zorgvuldigheidsbeginsel niet alleen in het privalrecht, maar ook in het bestuursrecht niet uitshitend procedureel, maar ook materieelrechtelijk van aard. "het zorgvuldigheidsbeginsel reemt in het bestuursrecht een belangrijke plats in. Het heef enerzijds betrekking op de voorbereiding van besluiten, anderzijds op de wijze van besluiten zelf en op de inhoud van het besluit. ${ }^{053}$

Een tweede argument van Nicolaï tegen het zorgvuldigheidsbeginsel als algemeen beginsel van behoorlijk handelen heeft betreklking op de specifieke in de uitoefening van bestumrsbevoegdheden aanwezige thmenten van gezag, dienstbarheid en publieke belangenbehartiging. Deze maken de concretisering van het zorgvuldigheidsbeginsel op besturusrechtelijk terrein dermate verschillend wan die op privaatrechtelijk terrein (ook al zou het beginsel zuiver procedureel worden opgevat), dat het volgens hem meer verhelderend is om van twee verschillende zorgvuldigheidsbeginselen te spreken. ${ }^{54}$ Vooral specifieke bestursrechtelijke zorgvuldigheidseisen die uitdrukking geven aan het beginsel van actief dienstbetoon kumnen volgens Nicola. bimen een privaatrechtelijk zorgvuldigheidsbeginsel niet verklaard worden. Ook dit argument overtuigt niet. In bestuursrecht én privaatrecht komen zeer uiteenlopende gezags- en machtsposities, dienstbaarheid en eisen van rekering houden met publiek belang voor. Mij lijkt dat het operationaliseren van op specifieke verhoudingen toegespitste eisen van zongwuldig handelen juist aan helderheid wint, als dat gebeurt vanuit het besef van een gemeenschappelijk basisbeginsel dat het bele recht doortrekt.

50 Nicolaî 1990, p. 231.

51 Vgl. Van Gerven 1983, p. 16 .

52 Bij zijn bespreking van hel "zorguldigheidsbeginsel" in artkel 6.3.1.1.hid 2 NBW (thans art.162 lid 2 boek $6 \mathrm{BW}$ ), dat buiten het bereik van de artikelen 6.1 .1 .2 (art. 2 boek $6 \mathrm{BW}$ ) en 6.5 .3 .1 (art. 248 boek $6 \mathrm{BW}$ ) mede de materiéle eisen van redelijkheid en billijkheid zou moeten bestrijhen, ziet NicoIall 1990, p.231-232, de algemene schakelbepaling betreffende redelijkheid en billikheid van artikel 3.1.116 jo artikel 3.1.1.13 NBW (thans ant. 15 jo art 12 boek $3 \mathrm{BW}$ ) ower het hoofd.

53 Memorie van Toelichting. TK 1988-1989, 21221, nr. 3; De parlementaire geschiedenis van de Algemene wet bestuurstecht, Eerste tranche (wet van 4 juni 1992, Stb. 315). p. 247.

54 Nicolin 1990, p. 232. 
Ten aanzien van het wertrouwensbeginsel is Nicolair bereid te spreken van een "gemene onderbouw", voor zover het gaat om een algemeen principe dat in het rechtsverkeer gewekt vertrouwen in beginsel bescherming verdient. Door de specifieke "verticale" relatie overheid-burger in het bestuursrecht kán de inhoud van een bestuursrechtelijk en cen privaatrechtelijk vertrouwensbeginsel volgens Nicolail niet samenvallen. Dat doet aan het onderliggend beginsel van behoorlijk handelen niet af, lijkt me. Evenals bij het zorgvuldigheidsbeginsel gaat het ook bij het operationeel maken van het vertrouwensbeginsel als algemeen beginsel van behoorlijk handelen telkens om een specifieke inkleuring naar de aard van de rechtsbetrekking en de context waarin het rechtsverkeer zich afspeelt. Dat het in het bestuursrecht gaat on een op publieke gezagsuitoefening gebaseerde "verticale" relatie komt in deze optiek juist helder naar voren.

Het evenwichtigheidsbeginsel, zoals Van Gerven dat voorstelt, beschouwt Nicolaï wél als een algemeen beginsel van behoorlijk handelen. Hij betoogt dat voor iedere bevoegdheidsuitoefening geldt dat "het resultaat van de afweging van de belangen niet op willekeur mag wijzen en dient te voldloen aan door de rechter (al dan niet "marginal") te toetsen eisen van redelijkheid en billijkheid." Het bestaan van een "recht" tot "misbruik" van een bevoegdheid acht hij in zijn algemeenheid onverenigbaar met de idee van een rechtsstaat. Daarom geldt het verbod van misbruik van bevoegdheid voor iedere uitoefening van bevoegdheid, ongeacht de aard van de bevoegdheid, aldus Nicolaï.

Geconcludeerd kan worden dat Nicolaï's argumenten tegen algenene beginselen die betrek king hebben op zorg en trouw onvoldoende hout snijden. Zijn erkenning van een evenwichtigheidsbeginsel kont in de richting van mijn woorstel over "alpartijdigheid". Waar hij bij evenwichtigheid het accent legt op niet onrechtvaardig handelen (verbod van willekeur), ligt in mijn voorstel wan alpartijdigheid het accent op rechtvaardig handelen (het daadwerkelijk evenwichtig meewegen van alle betrokken belangen). ${ }^{56}$ Mij lijkt dat deze actieve opvatting van everwichtigheid een goede basis biedt voor een opvatting van beginselen van behoorlijk bestuur als open normen die algemene regels geven voor de behoorlijke uitoefening van bestuursbevoegdheden, zoals Nicolai die ook zelf voorstaat.

In zijn poging tot systematisering komt Nicolai tot éen algemeen beginsel van behoorlijk bestuur dat altijd geldt, ongeacht de aard van het bestururshandelen: het beginsel wan correct en zorgwuldig bestuursgedrag. Als we correct bestuursgedrag hier vertalen als cerlijk, betrouwbaar bestuursgedrag, dan is dit beginsel te zien als een uitwerking in het bestuursrecht van de door mij voorgestelde beginselen trouw en zorg. Tien specifieke beginselen van behoorlijk bestuur spitst Nicolai toe op besluitend besturen en koppelt hij aan wijf fasen in het beslutvormingsproces. Beginselen van 1) correcte bejegening an 2) zorgvuldig onderzoek situeert hij in de fase wan voorbereiding van het bestuursbesluit. Aan de fase van de beslissingsprocedure koppelt hij het beginsel van 3) zorgvuldige beslissings-

55 Nicolai 1990 , p. 235.

56 Zie over het willekeurwerbod als gemeenschappelijke ondwgrens wan behoorlik overheidshandelen A.Q.C. Tak en R.E. Bakker, De centrale rol wan het willekeurverbod bij de toetsing wan overheidsMandelen, in Pubiekrechtelijke bewegingen, red. A. W. Heringa en W. Verheij, Deventer 1990, p. 205218. 


\section{Hoofdstuk 7}

procedure, aan de fase van het nemen van het besluit het beginsel van 4) deugdelijke besluitvorming. In de fase van het vaststellen van de inhoud van het besluit spelen het beginsel van 5) draagkrachtige motivering, 6) het gelijkheidsbeginsel, 7) het vertrouwensbeginsel en 8 ) het beginsel wan redelijke en billijke belangenafweging. Tenslotte situeert huj in de fase van de kennisgeving van het besluit de beginselen van 9) zorgvuldige kennisgeving en varn 10) kenbare motivering. In het merendeel van deze specifieke beginselen van behoorlijk bestuur zijn gemakkelijk contextafhankelijke aspecten van zorg of trouw te onderkennen. Voor het overige sporen deze beginselen - met name het gelijkheidsbeginsel en dat van redelijke en billijke belangenafweging - met de basiseis van alpartijdigheid.

In de bespreking van de abbb tot nu toe is vooral sprake van betrouwbaar en zorgvuldig overheidsbestuur. Waar blijft in dit verhaal de vrijheid wan de burger? "Naar huidig inzicht is het bestuur niet meer te typeren als de overheid die over de burger beslist zonder met diens zienswijze rekening te houden. Weliswaar is het bestuur in de eerste plaats gebonden aan de regels van de wetgever en aan de resultaten van de politieke besluitvorming, maar binnen die grenzen moet het ook rekening houden met de belangen van de bij de besluitvorming betrokken burger zoals die burger deze zelf ziet. Dit vergt een andere benadering van de burger, waarbij sprake is van een betere communicatie dan vroeger noodzakelijk. werd geoordeeld. ${ }^{257}$ In deze passage in de Memorie van toelichting van een in 1989 aan de Tweede Kamer aangeboden ontwerp Algemene wet bestuursrecht komen als kaderprincipes van deze wet naar voren: subjectiviteit van de burger, wederkerigheid van de relatie bestuur-burger en actieve zorgplicht van het bestuur. ${ }^{58}$ Daarin zijn niet alleen aspecten van zorg en trouw te onderkennen, maar vooral ook de principiële vrijheid van de burger om naar eigen inzicht voor eigen belangen op te komen en de rechtsplicht van de overheid om deze viriheid te respecteren.

De Algemene wet bestuursrecht $(\mathrm{Awb})$ is, ter codificatie van het bestuursrecht, opgezet als "aanbouwwetgeving". In de eerste tranche $e^{59}$ is wat de abbb betreft vooral aandacht besteed aan aspecten van zorgvulaligheid en belangenafweging. Zo staat bij voorbeeld in artikel 3:2 Awb dat het bestuursorgaan bij de voorbereiding van een besluit de nodige kennis vergaart omtrent de relevante feiten en de af te wegen belangen. In artikel $3: 3 \mathrm{Awb}$ staat dat het bestuursorgaan de bevoegdheid tot het nemen van een besluit niet gebruikt voor een ander doel dan waarvoor ze is verlcend. Artikel 3:4 lid 1 Awb handelt over het afwegen van de betrokken belangen en in het tweede lid van dit artikel stat dat de voor een of meer belanghebbenden nadelige gevolgen van een besluit niet onevenredig mogen zijn in verhouding tot de met het besluit te dienen doelen.

In aanvulling op de algemene zorgvuldigheidsplicht ten aanzien van het vergaren van kennis omtrent relevante feiten en af te wegen belangen is voor beschikkingen in hoofdstuk 4 van de Awb het horen van belanghebbenden in de voorbereidingsfase geregeld. Een

$58 \quad$ Nicolar 1990, p. 180.

59 Wet wan 4 juni 1992, Stb. 315. 
hoorplicht is ook te vinden in hoofdstuk 7 , betreffende de bezwarschriftprocedure. Daarover is in de parlementaire geschiedenis van de $A w b$ een passage te vinden die naadloos aansluit bij een gespreksmodel van recht. Het betreft de volgende opmerking van minister van justitie Hirsch Ballin: "In de ontwerp-Algemene wet bestursrecht worden een antal elementaire eisen gesteld aan de inrichting van de bezwaarschriftprocedure. De meest voor de hand liggende en meest wezenlijke is, dat het orgaan dat moet beslissen op het bezwaarschrift ook van oor tot oor en van aangezicht tot aangezicht in contact treedt met de "belanghebbende."

De mooie woorden van de minister worden in de $A$ wb niet waargemaakt voor het geval dat het bezwaar "kennelijk ongegrond" is. Dan kan van het horen van belanghebbenden worden afgezien (artikel 7:3 onderdeel $b$ Awb). De bedoeling is om de aan de bezwaarschriftprocedure verbonden bestuurslasten te verminderen zonder wezenlijk afbreuk te doen aan de rechtsbescherming van betrokkene. ${ }^{61}$ Het probleem is echter ${ }^{\text {dat }}$ je niet vooraf maar pas achteraf kunt weten of horen iets kan bijdragen. Een in de Tweede Kamer ingediend amendement om onderdeel $b$ van artikel 7:3 Axw te laten wervallen is echter verworpen. ${ }^{62}$

In de optiek van drie beginselen van mensenrecht is de genoemde nitzondering van de hoorplicht een voorbeeld van cen gebrek aan vrijheid van de burger (private autonomie), dat correspondeert met een gebrek aam zorg aan de kant van overheidsorganen. Dat deze uitzondering op de hoorplicht het gevolg is van democratische besluitvorming in het wetgevingsproces (vitoefening van publieke autonomie) doet daar niet aan af. Als de burger zich naar eigen inzicht door niet gehoord te worden rechtens te kort gedaan voelt, dan is in ieder geval de weg naar de rechter nog open. Deze zal dan mede toetsen of terecht van het horen van belanghebbenden is afgezien. Aan de kant van het wetgevingsproces is de vraag wat terecht komt van het (te zijner tijd op zijn betrouwbaarheid te toetsen) voornemen om aan deze problematiek bijzondere aandacht te schenken bij de volgens artikel 9:3 Awb voorgeschreven evaluatie van de Awb. A. met al is de Awb een aardig "oefenterrein" voor het toetsen van algemene beginselen van behoorlijk bestuur aan drie beginselen van mensenrecht, in het spanningsweld van administratieve macht en private en publieke autonomie.

\section{Het politiebegrip openbare orde}

Waar de Algemene wet bestuursrecht vooral is toegesnedlen op beschikkingen en andere schriftelijke overheidsbesluiten, gat het bij het handhaven wan de openbare orde als politiebegrip vooral om feitelijk handelen op strat en ander openbaar terrein. "Het begrip openbare orde duidt hier een rechtens relevante feitelijke situatie aan die de grondslag

61 PG Awb 1, p. 72. 


\section{Hoofdstuk 7}

vormi voor de bevoegdheid tot bestuurligk optreden ter handhaving. ${ }^{\text {n.t. }}$ Als algemene beginselen van politierecht noemt Van der Meulen het proportionaliteitsbeginsel, het subsidiariteitsbeginsel, het evenredigheidsbeginsel en het beginsel van gematigdheid. Volgens hem is hier sprake van algemene beginselen van behoorlijk bestuur (zorgvuldigheidsbeginsel, evenredigheidsbeginsel, verbod van willekeur) "in een ander jasje." "655

Om tot een praktisch bruikbare omschrijving van het politiebegrip openbare orde te komen maakt Van der Meulen gebruik van twee onderscheidingen. ${ }^{66}$ De eerste betreft de functies van het openbare orde begrip. Wat ik eerder heb aangeduid als afwerende functie duidt hij aan als bevoegdheidsbegrenzing. De opleggende functie duidt hij aan als bevoegdheidsgrondslag. In beide functies relateert hij openbare orde aan de samenleving als geheel.6" Inhoudelijk koppelt hij de functie van bevoegdheidsbegrenzing aan een harde kern van elementaire normen die de grondslag van de samenleving vormen. In de functie van bevoegdheidsgrondslag ziet hij het openbare orde begrip veel ruimer, met het oog op de talloze aspecten van de organisatie van de samenleving. Hij verwijst in dit verband onder andere nat openbare orde in het kader van de huishouding van de Gemeente (artikel 168 oude Gemeentewet). De grens van de gemeentelijke huishouding ligt bij de bijzondere belangen in de private sfeer van de ingezetenen. ${ }^{6.8}$

Als bevoegdheidsbegrenzing wordt het begrip openbare orde gebruikt om een grens te stellen aan een algemene regel. In mijn studie komt dit neer op begrenzing van private autonomie, zoals in het contractenrecht. De bevoegdheidsgrondslag betreft de operationele functie van het openbare orde begrip. Deze operationele functie komt neer op het onder de noemer openbare orde uitoefenen van bestuurlijke macht die democratisch gelegitimeerd moet worden door uitoefening van publieke autonomie.

De tweede onderscheiding heeft betrekking op de betekenissen van het openbare orde begrip. Hier makt Van der Meulen onderscheid in een normenstelsel en een feitelijke situatie. Waar met het openbare orde begrip rechtsnormen worden aangeduid gaat het steeds om "een min of meer beperkte groep normen ter onderscheiding van het geheel aan normen". Als rechtsfeit ziet openbare orde steeds op "een complex en uitgebreid geheel in de fysicke werkelijkheid. politiebegrip openbare orde op. Terecht, denk ik. Maar ik denk óók dat de grote verwevenheid wan openbare orde als rechtsfeit met het achterliggende normenstelsel niet te ontkennen valt. Dat wordt duidelijk als openbare orde als rechtsfeit in een handelingsperspectief Van der Meulen 1993. 24. Artikel 3:1 Awb bepaalt dat de in de Awb gecodificeerde abbb ook gelden wor andere handelingen dan beshiten, voor zover do aard van deze handelingen zich dantegen niet verzet. De aard van feitelijke politiehandelingen lijkt zich inderdaad niet te veizetten tegen ioetsing aan abbl. Zie daatover $V$ an del Meulen 1993, p. $294 \mathrm{v}$. met literaturverwijzingen.

66 Van der Meulen 1993, p. 14 v.

67 Van der Meulen 1993, p. 15, verwijst in dit verband nar De Vareilles-Sommieres, Des lois d'ordre public en de la dérogation aux lois, 1899

68 Wan der Meulen 1993, p. 18, werwijst nat het bekende "Wilnisser Visser-arrest" van de Hoge Raad van 13 febrtari 1922 , NJ 1922, p. 473 . 
wordt bekeken als het resultaat van feitelijke openbare ordening volgens een bepaald normenstelsel. De verwevenheid van het reële en het ideële in het politiebegrip openbare orde is ook terug te vinden in de historische ontwikkeling van het politiebegrip zelf.

Tot in de achtitiende eeuw drukte het begrip politie praktisch de complete overheidsfunctie uit. ${ }^{70}$ Politie had toen de betekenis van bestuur. In die betekenis werd de gemeentelijke Apv, nu Algemene plaatselijke verordening, vroeger Algemene politieverordening genoemd. "Naarmate zich geleidelijk in verband met de groei van overheidstaken afzonderlijke ministeries vormden, werd politie als overheidsfunctie beperkt. Gaandeweg vielen overheidstaken als de zorg voor de staatsorganisatie en voor de exteme veiligheid buiten het bereik van het politiebegrip. Tenslotte werd daaronder nog slechts begrepen de zorg voor de interne veiligheid van het land. In deze ontwikkelingsgang is de betekenis van politie als functie teruggebracht tot bescherming van orde, rust en veiligheid in de samenleving. Deze betekenis komt overeen met "het liberale feitelijke begrip openbare orde (rust op straat)." ${ }^{, 72}$ Maar dat wil niet zeggen dat in dit primair feitelijk politiebegrip openbare orde de ideeje factoren, die betrekking hebben op het normenstelsel als geheel, verdwenen zijn.

De geschiedenis van politie als ambt zoals wij dat nu kennen begint na de Franse overheersing in 1813. De in het Franse recht tot ontwikkeling gekomen tweedeling in judiciele politie (opsporing van strafbare feiten) en bestuurlijke politie (handhaven van de openbare orde en voorkomen van misclijven) werd destijds in Nederland wel overgenomen, maar niet consequent toegepast. Afkeer van de geheime staatspolitic van Napoleon schijnt daaraan in de weg te hebben gestaan. Pas in 1957 is het gelukt de totale politietaak in een Politiewet te regelen. Artikel 2 van de Politiewer" geeft de politie tot taak "in ondergeschiktheid aan het bevoegd gezag en in overeenstemming met de geldende rechtsregelen te zorgen voor de daadwerkelijke handhaving van de rechtsorde on het verlenen van hulp aan hen, die deze behoeven."

Onder de "daadwerkelijke handhaving van de rechtsorde" in artikel 2 Politiewet valt zowel de strafrechtelijke handhaving van de rechtsorde als "het handhaven van de openbare orde" als bestuurijk onderdeel van het handhaven van de rechtsorde. Als de politie optreedt ter strafrechtelijke handhaving van de rechtsorde, staat zij onder gezag van de officier van justitie (artikel 13 Politiewet). ${ }^{74}$ Treedt de politie op ter handhaving van de openbare orde en ter uitvoering van de hulpverleningstaak, dan staal zij onder gezag van de burgemeester (artikel 12 Politiewet). ${ }^{75}$ Dat de burgemeester bij de handhaving van de openbare orde

Wgl.J.H. Suyver, Politie in de rechtsonde, Zwolle 1986; F. Ferrick, Politie in Nederland, Zwolle 1982.

7 J.W. Edinga, De model Algemene platselike verordening in 2000, Regelmaat 1995/1, p. 11.17.

72 P.H. Bakker Schut, T. Prakken en Th. de Roos, Politiek protest in de rechtszan, Recht en Kriliek. 1984, p. 51. Vgl. Van der Meulen 1993, p. 20.

73. Voorheen artikel 28 . Op 1 april 1994 is de neuwe Politicwet van 9 december 1993, Stb. 724, in werking getreden.

74 Vootheen artikel 36 Politiewat 1957

75 Voorhern antikel 35 Politiewet 1957. 


\section{Hoofdstuk 7}

het gezag heeft over de politie staat sedert 1851 ook in de Gemeentewet. ${ }^{76}$ Darmee staat een als consistent en berrouwbaar bedoelde in het politiebegrip openbare orde jngebakken zorgplicht van de overheid ten aanzien van ordehandhaving juridisch buiten kijf. De vraag is of en zo ja in hoeverre deze ordehandhaving gericht is op vrijheid van de burger.

Om de ordehandhavende taak te situeren bimnen het geheel van overheidstaken, bespreekt van der Meulen twe hoofdtaken van de overheid in de rechtsstaat. De eerste staatstaak betreft het algemeen belang, het waarborgen van de continuilteit van de samenleving als zodanig. De rechtsstaat voegt daar als tweede taak waarborging van de individuele wrijheid aan toe. ${ }^{77}$ Ordehandhaving is gegrondvest in het geweldsmonopolie van de overheid. Met het oog daarop dient sprake te zijn van een deugdelijke democratisch-wettelijke onderbouwing met voldoende waarborgen voor de individuele vrijheid. ${ }^{78}$ Deze opvatting zet het politiebegrip openbare orde in een democratisch perspectief van vrijheid.

Bij een nadere bepaling van vrijheid maakt Van der Meulen onderscheid tussen drie hoofdaspecten: onaantastbaarheid, uitingsvrijheid en bewegingsvrijheid. Deze kernvrijheden hebben naast een hoge intrinsieke waarde (zij zijn ieder voor zich erkend als grondrecht) ook een hoge extrinsieke waarde. Daarmee bedoelt hij situaties waarin deze kernaspecten van vrijheid geen doel in zichzelf zijn maar middel tot het realiseren van andere waarden. ${ }^{7 "}$ Ordehandhaving door de politie betreft rechtstreeks het fundamentele recht op bewegingsvrijheid van betrokkenen in de openbare ruimte. De overheid heeft een structurele zorg voor het open houden van de openbare ruimte. Daarnaast treedt de overheid ook ordenend op met betrekking tot het "vluchtig" gebruik van de openbare ruimte, "hel alledaagse gebruik waarbij de imrichting van de ruimte en de mate van structurele veiligheid als gegeven gelden (constante factoren zijn)." ${ }^{8 i}$ Dit ordenend optreden impliceert volgens Van der Meulen vrijwel steeds zowel bescherming als beperking van het fundamentele recht op bewegingsvrijheid.

Interventies in de beide andere kernaspecten van vrijheid - onaantastbaarheid en titingsvrijheid - zijn volgens Van der Meulen niet aan ordehandhaving inherent. "Indien daarvan in een concreet geval sprake is, behoeft dit een bijzondere rechtvaardiging." Als ik her goed zie dan is deze op het eerste oog vanwege de duidelijkheid antrekkelijke opvatting vanuit een oogpunt van rechtsbescherming niet ongevaarlijk. Daarbij denk ilk zowel aan het nier eisen van teen bijzondere rechtwaardiging bij beperkende interventies in het aspect bewegingsvrijheid als aan het wét eisen van een bijzondere rechtvaardiging, óók bij beschermende interwenties, in de aspecten onaantastbaarheid en witingsvrijheid.

Thans in artikel 174 wan de nieuwe Gemeentewet van 14 februari 1992, Stb. 96.

Vaudar Meulen 1993, p. 7 .

Van der Meulen 1993, p. 13.

Van der Meulen 1993, p. 13.

Van der Metilen 1993, p. 30. koppelt ieders gelike recht van de openbare ruinte gebruik te maken overenkonstig de daraan gegeven bestemming aan het (nog net) verschoond zijn van een legitimatieplicht en duan het Souverein bestuit van 12 december 1813 . Stcrt. 1814, nr. 4 .

Van der Menten 1993, p. 33. 
Streven naar optimale bewegingsvrijheid voor ieder lijkt als uitgangspunt met het oog op het algemeen gebruik van de openbare ruimte passend. Dit uitgangspunt impliceert echter naar ik meen dat rekening wordt gehouden met de hoge "extrinsieke waarde" van dit kernaspect van vrijheid, als middel tot het realiseren van andere kernaspecten van vrijhoid (onaantastbaarheid en uitingsviijheid). Mij lijkt dat iedere "openbare orde" interventie gerechtvaardigd moet kunnen worden met het oog op het warborgen van individuele vijiheil in de publieke ruimte. Dat geldt, ongeacht welk kernaspect van vrijheid in de feitelijke situatie op de voorgrond staat. Voor uitingsvrijheid zal meestal zonder meer duidelijk zijn dat ze direct in het verlengde van bewegingsvrijheid ligt. Bij onaantasibaarheid valt dat misschien niet direct op, omdat het daarbij gaat om de persoonlijke levenssfeer. Het gaat om de vrijheid van de burger on datgene wat hij voor zich wil houden af te schermen van anderen en met name ook van overheidsinterventie. Toch lijkt mij dat eerbiediging van de persoonlijke levenssfeer bij het gebruik van de openbare ruimte wel degelijk mede inherent is aan ordehandhaving.

Laten we als voorbeeld nemen twee untspraken van de Hoge Raad van 14 oktober 1986.2 In de beide arresten, die over hetzelfde geval gaan, staat centraal de rechtmatigheid van "schaduwen", observeren en volgen door de politie, in een fase watarin geen strafbare feten zijn gepleegd en tegen de geobserveerde personen geen redelijke verdenking bestaat. Er is geen sprake van opsporing in de zin van strafrechtelijke handhaving van de rechtsorde. Als wettelijke basis voor het schaduwen gat de Hoge Raad uit van artikel 28 (thans artikel 2) Politiewet. Ten aanzien wan de klacht dat met het schaduwen door de politie inbreuk wordt gemakt op het in artikel 8 lid 1 van het Europees mensenrechtenverdrag beschermde privacy-recht overweegt de Hoge Raad dat deze klacht "reeds hierom" geen doel treft "omdat de verbalisanten blijkens hun tot het bewijs gebezigde rellaas zich hebben beperkt tot waarneming van hetgeen in het openbaar geschiedde." Hoge Raad de toetsingskous af. De waarneming komt in dit geval neer op het door de politie drie uur lang observeren van een stilstaande auto, gevolgd door het inzetten van een achtervolging vóórdat het bericht komt dat een inbraak is gepleegd. Pas na dat bericht kunnen de inzittenden van de auto als verdachten worden beschouwd.

"Waameming van hetgeen in het openbaar geschiedde" kan worden beschouwd als bij uitstek horende bij de openbare orde tak wan de politie. Als het goed is hoeft de politie in het kader van ordehandhaving zelfs praktisch niets anders te doen dan waarnemen wat in het openbaar gebeurt. Maar of volgehouden kan worden dat waameming in het openbaar "reeds hierom" geen inbreuk oplevert op eerbiediging van de persoonlijke levenssfeer, omdat en zolang ze zich beperkt to datgene wat in het openbaar gebeurt is nog maar de vraag. Stel je voor: je zoekt een zonnig plekje in het stadspark op om op je gemak de krant te lezen of te mijmeren over dingen van het leven. Een stel politiemensen kom tegenover je staan en behandelt je als een object van systematische, indringende waarneming in het openbaar. Die waarneming duurt net zo lang als je het nog volhoudt op dat platsje onder de zon. Tast de politie in die situatie je vrijheid van persoonlijke levenssfeer 


\section{Hoofdstuk 7}

aan? Mij lijkt van wel. Een redenering als die van de Hoge Raad, dat de waaneming "reeds hierom" geen inbreuk oplevert op je persoonlijke levenssfeer omdat en zolang deze zich beperkt tot datgene wat in het openbaar gebeurt, schiet hier eenvoudig te kort. Als respect voor en bescherming van de persoonlijke levenssfeer zich niet mede tot de openbaarheid uitstrekt, dan kan de openbare ruimte gemakkelijk verworden tot een voor menselijke vrijheid onherbergzame ruimtelijke sfeer. Daarin wordt de vrijheid waarborgende functie van ordehandhaving opgeofferd aan een technisch-functionele ordening van bewegingswrijheid.

"Elke wrijheid bevat een kem die bescherming behoeft, ondat anders ce betreffende vrijheid zelf verloren gaat", zegt Van der Meulen ${ }^{*}$ Tegen de achtergrond van de feitelijke macht van het geweldsmonopolie van de politie wil ik daar sterk aan vasthouden. Als niet wordt vastgehouden aan een integrale bescherming van algemene én individuele vrijheid in al haar kemaspecten, dan valt van het politiebegrip openbare orde geen bemiddelende functie in dienst van mensenrecht te verwachten. Eerder is dan te verwachten dat het openbare orde begrip als bevoegdheidsgrondslag (voor de politie) in dienst komt te staan van bevoegdheidsbegrenzing (van de burger).

\section{Misdrijven en overtredingen betreffende de openbare orde en de zeden in het Wetboek van Strafrecht}

Het privaatrecht en ook het staats- en bestuursrecht worden doorgaans in de praktijk gebracht zonder dat daar een rechter aan te pas komt. Afgezien van transacties in het voortraject is het strafrecht daarentegen aangewezen op erkenning en toepassing door de rechter in het strafproces. Dat is niet verwonderlijk. Het strafrecht wordt gekenmerkt door het toevoegen van leed, anders dan via eigenrichting door betrokken partijen. Vanaf de Germaanse tijd tot aan de Bataafse omwenteling van 1795 is het strafproces geleidelijk veranderd van een openbaar, mondeling proces waarin het initiatief bij de klager lag en de rechter een lijdelijke rol speelde in een min of meer schriftelijk proces, waarbij van rechtswege werd vervolgd en waarin de rechter het onderzoek naar de materielle waarheid in handen had. Met de Franse overheersing $(1810-1813) \mathrm{kwamen}$ idealen over het mondeling karakter wan het strafproces in de belangstelting. Mede daardoor geïnspireerd aijn openbatarheid en mondelinge procesbehandeling leidende beginselen in het Nederlands Wetboek van Strafvordering van 1838 geworden. Ook de ontwerpers van het thans nog geidende Wetboek van Strafvordering van 1926 hebben de bedoeling gehad het onclerzoek ter terechtzitting een openbaar en mondeling karakter te geven. Dat aan het "onmiddellijke" karakter wan het strafproces afbreuk wordt gedaan naarmate de rechter meer afgaat op het schriftelijk materiaal uil het vooronderzoek en verklaringen van horen zeggen en anonieme getuigenverklaringen als bewijsmiddelen accepteert, mag duidelijk zijn. ${ }^{85}$

85. Dorothe Gare, Het onmiddellijkheidsbeginsel in het Nederiandse strafproces, Amhem 1994, over de ontwikkeling van het Nederlands strafproces tot 1926, p. $3-40$, over de ontwikkelingen sedert $1926, \mathrm{p}$. 79-142. Zie ook G.P.M.F.Mols, Staande de zitting; Een beschouwing over het onmiddellijkheidsbeginsel. Anhem 1989. 
Ten aanzien van de inhoxd van het strafrecht werd in Nederland met de inlijuing bij Frankrijk in 1811 de Franse Code Pénal van kracht. In afgezwakte vorm is die tot 1886 in werking gebleven. Zo werden in 1854 de lijfstraffen en in 1870 de doodstraf (behalve in het militair strafrecht) afgeschaft. Op 1 september 1886 is het Wetboek van Strafrecht (Sr) in werking getreden, dat tot op heden van kracht is gebleven. ${ }^{\text {sh }}$ Daarnaast zijn strafbepalingen ook te vinden in bijzondere wetten, in gemeentelijke en andere verordeningen. Denk bij voorbeeld aan de Wegenverkeerswet, de Wet Eonomische Delicten en Algemene platselijke verordeningen.

Al is het strafrecht eigenlijk bedoeld als "ultimum remedium", voor "uilschieters" van onrecht," het functioneert ók als een soort "vangnet" voor allerlei soms zeer lichte vergrijpen. $^{88}$ De onderscheiding in misdrijven en overtredingen is een kwestie van een politiekjuridische keuze ten aanzien van een meer of mindere mate van strafwaardigheid. Met het oog daarop worden misdrijven in het strafrecht anders behandeld dan overtredingen. Zo moet bij misdrijven steeds het bewijs van cen worm van opzet of schuld geleverd worden. Bij overtredingen gaat het doorgaans om een pure gedraging. Gevangenisstraf kont alleen bij misdrijven voor, niet bij overtredingen." Het Wetboek van Strafrecht is ingedeeld in drie boeken. In het eerste boek staan algemene bepalingen dic voor het gehele strafrecht gelden. In het tweede boek staan misdrijven, in het derde boek overtredingen. Naast een groot aantal andere categorieën misdrijven en overtredingen (bijvoorbeeld betreffende de algemene veiligheid van personen en goederen) bestaan speciale categorieën misdrijven en overtredingen betreffende de openbare orde en de zeden. Mijn keuze voor deze categoriezon is geinspireerd door het begrippenpaar openbare orde en goede zeden in het privaatrecht.

Ik begin met de categorie die het minst om het lijf heeft: overtredingen betreffende de zeden. Onder deze titel staat nog maar één artikel (de overige zujn vervallen): het verbod op openbare dronkenschap (artikel $453 \mathrm{Sr}$ ). Als we het zedelijke niet zedenmeesterachtig opvatten, maar in het perspectief van mensenrechtelijk georiënteerde zedelijke beginselen, dan heeft een zelfstandig verbod van openbare dronkenschap in onze tijd geen reden van bestaan meer. Ordeverstoring in dronkenschap is geregeld onder overtredingen betreffende de algemene veiligheid van personen en goederen (artikel $426 \mathrm{Sr}$ ).

In tegenstelling to de categorie overtredingen betreffende de zeden laat de categoric misdrijven tegen de zeden (artikelen 239-253 Sr) niet het beedd van leegloop zien. In het merendeel van de twintig in deze titel ondergebrachte artikelen gaat het mede of uitsluitend om de bescherming van kinderen. Het betreft onderwerpen als het aanbieden aan kinderen van pornografie of het gebruiken van kinderen voor pornografie of voor seksuele gemeenschap, ontucht of koppelarij, het dronken maken van kinderen en het afstaan van

86 Hazewinkel-Suringa/Remmelink, Inteiding to de studie van het Nederlandse strafrecht, wijtiende druk, Alphen a.d. Rijn 1996, p. 53 \%.

87 Hazewinkel-Suringa/Remmelink 1996, p. 10.

88 C. D. van der Vijwer, De burger en de zin wan strafrecht, Lelystad 1993, p. 35.

89 Zie voor de talrike werschilpunten tussen misdriven en overtredingen Hazewinkel-Suringa/Remmelisk 1996, p. $100-107$. 
kinderen voor ongezond werk. Los van minderjarigen zijn delicten opgenomen zoals ongeweniste confrontatie met pornografie, verkrachting, gemeenschap of ontucht met een bewustelloze of geestelijk gestoorde en vrowwenhandel. Het gaat om misbruik van kinderen en andere zwakke groepen, wooral op seksueel gebied. Als zedelijk beginsel is dan vooral bescherming van onvolwassen indiwiduele vrijheid (op seksueel gebied) als maatschappelijke zorgplicht voor de zwakkere het richtsnoer. Op terreinen als dit, waar mensen bijzonder kwetsbaar zijn, is het gevaar uiteraard groot dat zorg kan omslaan in moralistisch paternalisme. In het concept dat ik voorsta dringt zich hier de rol op van het beginsel trouw, in een betekenis van integere rechtsbescherming die duurzaam gericht is op respect voor wrijheid voor ieder.

De titel "Overtredingen betreffende de openbare orde" (artikelen 429bis-442a Sr) lat een bonte verzameling strafbepalingen zien. Daarin lopen meer en minder actuele onderwerpen uiteen van smalende godslastering in het openbaar, via discriminatie in ambt, beroep of bedrijf, naaktrecreatie, burengencht, bedelarij, landloperij, het onbevoegd gebruik maken van Rode Kruis kentekens en telefonische colportage voor een liefdadig doel tot het onbevoegd opnemen van een pleegkind. In deze categorie worden verschuivingen in de beleving van wat strafwaardige ordeverstoring is en het vergaarbak-karakter van het openbare orde begrip aardig gedemonstreerd. Als aangenomen wordt dat de titel de lading dekt, dan moet in ieder geval in elke bepaling een of ander aspect van openbaarheid te vinden zijin. Er is echter niet in iedere bepaling een feitelijk ruimtelijk openbaarheidsaspect aan te wijzen. Het gaat hier kennelijk niet uitsluitend om openbare orde in een ruimtelijke betekenis van het ordelijk verloop van het gemeenschapsleven op een bepaalde plaats. Zo stelt artikel 429 quater $\mathrm{Sr}$, de laatste keer geactualiseerd in 1991, strafbaar het in de uitoefening van een ambt, beroep of bedrijf discrimineren van personen wegens hun ras, thun godsdienst, hun levensovertuiging, hun geslacht of hun hetero- of homoseksuele gerichtheid. In dit artikel, waarop ik hierna terugkom, bestrijkt het openbaarheidsaspect de gehele sociaal-economische sfeer.

Onder de titel "Misdrijven tegen de openbare orde" (artikelen 131-151c Sr) loopt het scala onderwerpen uiteen van opruiing in het openbaar tot enig strafbaar feit, mislukte uitlokking, belediging, aanzetten tot, deelnemen aan of steunen van discriminatie, via huisvredebreuk, het aftuisteren van gesprekken binnen of buiten met een apparaat, grafschending en het wegmaken van lijken tot het afstaan van kleine kinderen uit winstbejag. Bij deze verzameling misdrijven is duidelijker dan bij de overtredingen dat het openbare orde begrip hier meér inhoudt dan rust en veiligheid op straat en ander openbaar terrein. Er zil bij voorbeeld "ook iets in van de mensen niet hinderen in hun door de rechtsorde gegeven vrijheidl van privéleven met inbegrip van de religieuze sfeer, in welk verband ik aan delicten als huisvredebreuk en godslastering denk ${ }^{190}$ Naast bemiddelende bescherming van vrijheid in de publieke en private sfeer zijn hier evenals bij de overtredingen gevallen te vinden waarin expliciet de zorg voor zwakkeren en het vrijwaren van mensen tegen achierstelling voorop staan.

90 Noyou/Langemeijer-Remmelink, Wetboek wan Strafrecht, Boek II, titel V, Misdrijven tegen de openbare orde, p. 137 
Op het vrijwaren tegen achterstelling, of anders gezegd het witbannen van vormen van discriminatie, ga ik hier wat nader in. De vragg is of de ontwikkeling van strafbepalingen op dit gebied gezien kan worden in samenhang met de ontwikkeling van de mensenrechtelijk georiënteerde beginselen wrijheid, trouw en zorg. De ontwikkeling van strafbepalingen die ik op het oog heb begint met de invoering in 1934 van de artikelen $137 \mathrm{c}$ en $137 \mathrm{~d} \mathrm{St}$ als misdrijven tegen de openbare orde." De genoemde artikelen betreffen in die tijd kort gezegd het in het openbar zich in beledigende vorm uitlaten over een volksgroep (artikel $137 \mathrm{C} \mathrm{Sr}$ ) en het verspreiden van voor een volksgroep beledigende geschriften of afbeeldingen (artikel $137 \mathrm{~d}$ Sr). Volgens de Memorie van Toelichting is de invoering noodzakelikk ondat met name beledigingen tegen "onze Israelitische medeburgers" in die tijd een soort "epidemisch karakter" krijgen." De Duitse bezeting heef aan vervolgingen betreffende belediging van Joden een einde gemaakt, "waarna van een serienze herleving van de artikelen $137 \mathrm{c}$ en $\mathrm{d} \mathrm{Sr}$ in hun oude vorm in feite geen sprake meer is geweest, hoewel nog wel een incidentele vervolging werd ingesteld" "w"

De artikelen komen weer in de belangstelling met het oog op het Intenationad Verdrag van New York wan 7 maart 1966, inzake de nibanning van alle vomen van rassendiscriminatie. ${ }^{24}$ Het verdrag legt de deelnemende staten onder andere de verplichting op (in artikel 4 sub a) om bij de wet strafbaar te verklaren het verspreiden van racistische denkbeelden, het anzetten tot rassendiscriminatie met inbegrip van racistische geweldpleging en het verlenen van steun aan racistische activiteiten. ${ }^{95}$ Deze verplichtingen geven aanleiding om de artikelen $137 \mathrm{c}$ en $137 \mathrm{~d}$ Sr aan te scherpen en toe te spitsen op belediging, het anzetten tot hat of het discrimineren van een groep mensen wegens hin ras, godsdienst of levensovertuiging. Een nieuw artikel $137 \mathrm{e} \mathrm{Sr}$ verbied het anders dan ten behove van zakelijke berichtgeving openbaar maken of verspreiden van uitingen die beledigend zijn of aanzetten tot haat, discriminatie of geweld tegen mensen wegens ras, godsdienst of levensovertuiging.

Naast deze misdrijven tegen de openbare orde worden als overtredingen betreffende de openbare orde de artikelen 429 ter en 429 quater Sir ingevoerd. In artikel 429 ter wordt strabar gesteld hij die deemeemt an of geldelijke of andera stoffelike steun verleent aan activiteiten gericht op discriminatic van mensen wegens hun ras. In artikel 429 quater word strabaar gesteld hij die in de uitoefening wan zijn beroep of bedrijp in het gooderenm of dienstenverkeer ienand wegens zijn ras achterstelt. Aan godsdienst en levensovertuiging als discriminatiegronden is volgens de wetgever in die tijd geen behoefte, terwijl gestacht en seksuele geaardheid als discriminatiegronden door de regering worden afgehouden met de mededeling dat $20^{\circ} \mathrm{n}$ uitgebreidere strafbepaling de uitwoening van het Verdrag van New York te buiten zou gaan. ${ }^{\circ}$

91 Wet van 19 juli $1934,5 t b .405$.

92 Hand, II 1933-1934,237, nr, 3, p. 2-3; Wan der Neut 1986, p. 28.

93 Vander Neut 1986, p. 28.

Trb. 1966, 237 (Franse en Engelse tekst, Trb.1967, 48 (Nederlandse tekst). Inwerkingtireding in Nedarland 9 jaruari 1972 . Zie over dit verdrag ook par. 3 van dit hoofdstuk.

95 Vgl. Van der Neut 1986, p. 31-32; Eskes 1988, p. $383 \%$

96 MvT. 9724, 1967-1968, p. 4, Hand. 11, 1969-1970, p. 4334 w; Van der Neut 1986, p. 36 


\section{Hoofdstuk 7}

De rekkijdte van artikel 429 quater Sr wordt na de invoering ervan in 1971 al snel als le beperkt ervaren, vooral met het oog op de vestiging in Nederland wan grote aantallen Surinamers en buitenlandse werknemers. Met een aanscherping van het artikel in 1981 wond het tegengaan wan achterstelling beoogd, niet alleen op de markt van goederen en diensten, mat ook op de arbeidsmarkt." Met ingang van 1 februari 1992 is artikel 429 quater Sir wéer aanzienlijk witgebreid en heeft het zijn huidige redactie gekregen: ${ }^{5} \mathrm{Hij}$ die in de uitoefening van een ambt, beroep of bedriff personen discrimineert wegens hun ras, hun godsdienst, hun levensovertuiging, hun geslacht of hun hetero- of homosekstele gerichtheid wordt gestraft met hechtenis van ten hoogste twee maanden of geldboete van de derde categorie."

In de loop van de parlementaire behandeling van de wijziging van artikel 429 quater $S \mathrm{~s}$ is ook cen misdaadvariant van deze overtreding ingevoegd, artikel $137 \mathrm{~g} \mathrm{Sr}$. Het verschil met de overtreding is, dat in artikel $137 \mathrm{~g}$ opzetteljk discrimineren wordt vereist en dat naast ras geen andere discriminatiegrond word genoemd. Ook van artikel 429ter Sr is een misdadvariant ingevoerd. Deze bepaling, artikel $137 \mathrm{f} \mathrm{Sr}$, is niet naast een corresponderende overtreding komen te staan, maar is, aangescherpt en uitgebreid, daarvoor in de plaats gekomen. Bij dezelfde wetswijziging zijn ook de discriminatiegronden in de artikelen $137 \mathrm{c}, 137 \mathrm{~d}$ en $137 \mathrm{e} \mathrm{Sr}$ aangevuld. Daarbij valt op dat in artikel $137 \mathrm{~d}$ (aanzetten tot haat of discriminatie) naast hetero- of homoseksuele gerichtheid ook geslacht wordt genoemd, terwijl in artkel $137 \mathrm{c}$ (opzettelijke belediging) geslacht wet wordt genoend. Stof voor een volgende aanscherping?

De uitbreiding en aanscherping in de loop van de jaren van strafbepalingen inzake discriminatie laten zien dat achterstelling van mensen wegens ras en andere genoemde gron* den steeds zwaarder als strafwaardig onrecht wordt aangemerkt. Zijn deze uitbreidingen en verschuivingen in het licht van feitelijke ontwikkelingen uit te leggen als pogingen tot een alpartijdige uitwerking van de mensenrechtelijke beginselen wrigheid, rouw en zorg? $\mathrm{k}$ denk van wel. Onder discriminatie of discrimineren wordt in het Weboek van Straftecht overeenkomstig artikel 90 quater verstaan "ellke vorm vain onderscheid, elke uitsluiting, beperking of woorkeur, die ten doel heeft of ten gevolge kan hebben dat de erkenning, het genot of de uitoefening op voet van gelijkheid van de rechten van de mens en de fundamentele vrijheden op politiek, economisch, sociaal of cultureel terrein of op andere torreinen van het matschappelijk leven, wordt teniet gedaan of aangetast." Dit discriminatiebegrip legt een directe juridische verbinding tussen achterstelling en mensenrechtelik gooribnteerde vrijheid. ledere achterstelling warn mensen op de genoemde gronden is een drecte antasting van menselijke virijheid en waardigheid. antek, 1 * bij artikel 429 quater $\mathrm{Sr}$; Van der Neut 1086, p. $39 \%$.

98 Wel van 14 november 1991 , Stb. 623. Artikel 429 ter is bij deze wet ingetrokken.

99 Het discriminatiebegrip van artikel 90 quater Sr correspondeent met artikel 1 lid 11 van het Verdrag van New York inzake de uibanning van alle vormen van rassendiscriminatie Zie hierover Van der Neut 1986, p. $29 \mathrm{v}$, met literaturvermeldingen. 
Het strafrechtelijk tegengaan van achterstelling met het oog op ieders gelijkwaardige vrijheid is een vorm van overheidszorg. Deze zorg op het niveau van de ordehandhavingsen misdaadbestrijdingsfunctie van het strafrecht moet gecombineerd worden mel zorg op het niveau van rechtsbescherming van de burger tegen de overheid. Juist de rechtsbeschermende functie van het strafproces bepaalt het rechtskarakter van het strafrecht en is bij uitstek georiènteerd op mensenrechtelijke beginselen van behoorlijk handelen. Kunnen dimensies van zorg in mensenrechtelijk perspectief op beide niveaus samengaan?

Aan de hand van recente wetgeving en wetswoorstellen op strafrechtelijk terrein laten Dorothé Garé e.a. als tendens de neiging van de Nederlandse overheid zien om internationaal erkende rechtsbeginselen instrumenteel in plaats van rechtsbeschermend toe te passen. ${ }^{100}$ Het gaat dan onder andere om het onmiddellijkheidsbeginsel, het externe en interne openbaarheidsbeginsel, het beginsel van de contradictoire procesvoering, de onschuldpresumptie en het privacy-beginsel. Al deze beginselen hebben te maken met een vije, eerlijke procesvoering naar het woorbeeld van het open gesprek.

Ik denk dat in het spanningsveld van een instrumentele en cen rechtsbeschermende opvatting van strafrechtelijke beginselen het beginsel trouw als verbindende factor tussen wrijheid en zorg van bijzonder belang is. Op het niveau van de bescherming van mensen tegen belediging en het aanzetten tot haat komt het aspect trouw mooi naar voren in een uitspraak van de Hoge Raad uit 1940. ${ }^{101}$ Daarin wordt een beroep van de verdachten op hun geloofsovertuiging door de Hoge Raad verworpen. De overtuiging van de verdachten betreft de bestrijding van godsdienstleiders. Daar kan volgens de Hoge Raad niet de noodzakk wit volgen om deze overtuiging te uiten in een vorm die "met uitsluiting van iedere mogelijkheid wan goede trouw zonder enige motivering aan de wederpartij in een keur van grievende en beledigende uitdrukkingen kwade en de meest lage doeleinden aanwijst." In het licht van zorg staat de "uitshiting van iedere mogelijkheid van goede trouw" hier gelijk atan het categorisch onthouden aan een ander wan een mijheid die de een wél voor ziclizelf opeist.

Een bemiddelende rol van het beginsel trouw ten aanzien van aan de ene kant adequate strafvervolging en aan de andere kant individuele rechtsbescherming is te illustreren aan de hand van de actuele discussie over strafrechtelijke ansprakelijkheid van journalisten die beledigende witspraken van derden citeren als bijdrage aan het publicke debat, bij voorbeeld over racisme. ${ }^{102}$ Met het oog op bepalingen in verdragen op het gebied van de mensenrechten heeft deze discussie een sterk international publiekrechtelijke inslag. Ik stel daarom voor de bespreking uit te stellen tot het volgende hoofdstuk. Als afsluiting van deze discussiebijdrage over strafrecht wil ik nog kon ingaan op discussie in het strafrecht.

100 Dorohbe Garé ea. (N.J.C.Mwerkgraep Strafrecht en Mensenrechen), Stratsburg: ijkphin of breekpurt?. NICM Bulletin 1995, p. $482-503$.

$101 \mathrm{HR} 4$ maart 1940, NJ 1940, 830. Zie daarover Noyon-Langemejer/Remmelink, auxek la (noot i) op arikel $137 \mathrm{cs}$ s.

102 Zie over deze discussic Fred Janssens, Belledigende uithatingen in de media, Opmerkingen mar aranleiding van EHRM 23 september 1994, Series. A 289 (Jessidd $\psi$. Denenarken, NMCM Bulletin. $1995, \mathrm{p} .124-141$ 


\section{Hoofdsituk 7}

In onderstande passage breng Peter Bal de idee van discussie in het strafrecht treffend naar voren. "Om de morele verwerpelijheid van het gedrag van de "dader" en diens aansprakelijheid te bepalen, mogen we niet het deelnemersperspectief verlaten en een objectiverend warmemersstandpunt tegenover hem innemen. We moeten met andere woorden "in gesprek" bljwen met de dader. Slechts wanneer alle perspectieven van het slachtoffer, de dader en de maatschappij openlijk aan de orde zijn gesteld, kan de morele lakbarheid en toerekenbaarheid van toegebrachte schade worden vastgesteld. Een dergelijke open discussie biedt bovendien aan de dader de gelegenheid om morele werantwoorde ij kheid op zich te nemen."

Als inhoudaije richtinnen voor "het gesprek met de dader" vraagt $\mathrm{Bal}$ aandacht voor mensernechten. Hij beschouwt deze rechten als de morele maatstaven voor juridische discoursen. Ze openen volgens hem de mogelikheid om de legitmiteit van het positieve strafrecht vanuit een moreel gezichtspunt te beoordelen. Naast een mensenrechtelijke fundering van een eerlijk strafproces pleit hij voor een inhoudelike rol voor mensenrechten in het strafrechtelijk discours. In deze visie moeten misdaaddefinities gefundeerd worden op ernstige schendingen van fundamentele rechten. Ook bij het overtreden van algemeen erkende strafrechtsnomen moet de mogehikheid wan een op mensenrechten gebaseerde rechtvardigingsgrond open blijven. Als tegenover elkar staande fundamentele rechten in het geding zijn, acht Bal enigerlei vorm van juridische controle via wetgever enwof rechter geboden. "In dit opzicht vervulten strafrecht en strafiechtspleging de rollen van morele hoeders in dit soort aangelegenheden, al zullen ze het debat hierover open moeten laten," $" 104$

Het pleidooi van Bal voor en richtinggevende procedurele én inhoudelijke rol voor mensentechten in het strafrech sluit aan bij mijn opvating van drie beginselen van mensenrecht als toetssteen voor het rechtskarakter wan recht. Dat geldt witeraard ook voor misdrijven en overtredingen betreffende de openbare orde en de zeden. Bal gaat uit van het juridisch niveau van mensenrechten zelf. In mijn voorstel wil ik de mogelijkheid van open discussie principieel open houden, ók als het gat om de juridisering van rechten die als fundamenteel ervaren worden. Daarom wil ik de achter juridische mensentechten liggende beginselen van behoorlijk handelen dienst laten doen als basaal richtsnoer voor het rechtskarakter van rechtsbeslissingen , ók in het strafrecht. Dat in de rechtsprakujk mensenrechen zélf als algemeen aanvarde juridische standard van behoorlijk handelen worden ervaren doet aan dit voorstel niet af. Integendeel, deze menserrechten zijn in mijn voorstel te beschowwen als algemeen aanvarde juridische witwerkingen van de mensenrechtelijke beginselen vrijheid, trow en zorg. Overigens gata ook Bal bij de interpretatie van mensentechten in het strafiecht uit wan het recht op persoonlijke vrijheid. Dar. mee wordt ook langs deze weg vrijheid als leidend beginsel van mensenrecht bevestigd.

103 Peter Bal, Wat dragt Habermas bij tot de ontwikkeling wan een discourstheorie van het stal(proces)rechl', Recht en Kritiek 1994, p. 152-169, zie p. 163 .

104 Bal 1994, p. 168, verwijst voor een genumceende beschouwing over de verhouding tussen mensenrechten en morele verantwoordelijkheid naar Raes 1992. 


\section{INTERNATIONAAL PUBLIEKRECHT}

\section{Inleiding}

Het internationaal publiekrecht is ontstaan uit het traditionele volkenrecht, dat oorspronkelijk alleen rechten en plichten van staten onderling regelde. Het bemoeide zich niet mel: mensenrechten. Na de eerste wereldoorlog werden in vredesverdragen regels over de behandeling wan minderheden opgenomen. "Hoewel ook dit afspraken ussen staten waren betroffen deze regelingen in de eerste plats mensen. Een eerste begin van mensenrechten trad het volkenrecht birnnen."

Na de tweede wereldoorlog is in een overgang van volkenrecht naar internationaal publiekrecht de opmars van mensenrechten op gang gekomen. De idee van een interne samenhang tussen drie beginselen van mensenrecht, warvan ik in deze studie uitga, sluit aan bij de doctrine van ondeelbaarheid en onderlinge afhankelijkheid van alle mensenrechten. Deze doctrine wordt aangehangen door de Verenigde Naties. Maar hoewiel relevante pogingen worden gedaan is ze nog niet vertaald naar de rechtspraktijk. ${ }^{2}$ Werkt wrijheid als leidend beginsel van mensenrecht de feitelijke achterstandspositie van sociale mensenrechten ten opzichte van klassieke vrijheidsrechten in de hand? Bij sociale rechten staat immers niet wrijheid, maar feitelijke zorg op de voorgrond. Deze kwestie roept de historische vraag op, hoe de voorrangspositie van klassieke vrijheidsrechten ten opzichte van sociale mensenrechten zich feitelijk ontwikkeld heeft.

Als model voor de historische ontwikkeling van de voorrangspositie van klassieke vrijheidsrechten ten opzichte van sociale mensenrechten schets ik de ontwikkeling van de vrijheid van geweten sedert de Griekse oudheid tot de erkenning als mensenrecht (par. 2), in 1950 in het Europees verdrag tot bescherming van de rechten van de mens an de fundamentele vrijheden (EVRM), in 1966 in het Internationaal verdrag inzake burgerlijke en politieke rechten (IVBPR). In een aparte paragraaf behandel ik daarna de vraag of cen algemeen geformuleerd mensenrecht op gewetensvrijheid, los van godsdienstige overtuiging, juridisch mogelijk is (par. 3). Deze bespreking is bedoeld on de juridisch-praktische houdbaarheid van een leidende positie van vrijheid als nensenrechtbeginsel op dê proef te stellen.

1 H.G. Schemers, Mensenrechten en internationaal publiekrecht, in P.B. Cliteur en A.P.M.J. Vonken, (red.), Doorwerking van mensentechten, Gronimgen 1993 , p. 143-151, p. 143.

2 Cees Flinterman, De ondeelbaarheid van de rechtem van de mens, in A.P.M. Coomans e.a. (red.), De toenemende betekenis van economische, sociale en culturele mensenrechtew, Leiden 1994, p. 1-7. 


\section{Hoofdstuk 8}

Het EVRM en het IVBPR zijn juridisch bindende verdragen op het gebied van de klassieke rechten var de mens. Verdragen op het gebied vam sociale rechten van de mens zoals het in 1961 in Europees werband overeengekomen Europees Sociaal Handvest (ESH) en het in 1966 in VN-verband gesloten International verdrag inzake economische sociale en culturele rechten (IVESCR) - zijn moeilijker juridisch hard te maken. De in deze verdragen aangenomen sociale rechten blijven als "ondergeschoven kind" in de schaduw wan burgerlijke en politieke rechten. ${ }^{3}$ Darmee strookt de praktijk inderdaad niet met de doctrine van de ondeelbarheid en onderlinge afhankelijkheid van alle rechten van de mens. Kunnen drie beginselen van mensenrecht in hun eenvoud een handje helpen om theorie en praktijk dichter bij elkaar te brengen? Bij het bekijken van de ingewikkelde leer van negatieve en positieve verplichtingen van staten uit het EVRM lijkt dat aannemelijk (par. 4).

Het begrip openbare orde komt in dit hoofdstuk pas kijken bij de in het vorige hoofdstuk uitgestelde bespreking van de discussie over strafrechtelijke aansprakelijkheid van joumaUisten die racistische uitspraken van derden publiceren (par. 5). De onopvallende rol die het begrip openbare orde in deze discussie speelt is op het punt van imhoud een bevestiging van een algemene inzetbaarheid van het begrip openbare orde, georiënteerd op drie beginselen van mensenrecht. De vraag naar functies leidt tot bundeling van eerder besproken deelfuncties in een universele bemiddelende functie van het begrip openbare orde (par. 6). Na een verkenning op het gebied van mensenrecht in de context van het Europees Gemeenschapsrecht (par. 7) kom ik in die context kort op dit bemiddelend openbare orde begrip terug (par. 8). Ik doe dat in een speculatieve beschouwing over het aanpakken van een actuecl rechtspolitiek probleem: discriminatie van "Europese vreemdelingen" ten opzichte van burgers van de Europese Unie.

\section{De ontwikkeling van de vrijheid van geweten tot klassiek mensenrecht $t^{4}$}

In de klassieke Griekse polisfilosofie vallen politiek en religie samen. De idlee dat het individu vanuit een morele overtuiging zelfstandige rechten tegenover de staat zou kunnen hebben ontbreekt. Onstreeks het einde van de vijfde eeuw voor Christus begint de politick-religieuze eenheid wan de polis af te brokkelen. Het inzicht ontstaat dat het politicke systeem niet een natummoodzakelijke ordening is maar het resultaat van menselijk handelen. Daardoor ontstal ruinte voor conflict tussen persoonlijke (private) en gemeenschappelijke (publieke) moraal.

3 Th. van Boven, Slotopmerkingen in A.P.M. Coomans e.a. (ved.), De toenemende betekenis wan economische, sociale on culturele mensenrechten, Leiden 1994 , p. 140-142, p. 140. Zie onk NJCMcommentaren inake de versterking wan het respect voor economische, sociale en culturele recluten, N.CMA-Bulletin, $19-3$ (1994), p. 276-296 en NJCM-Bulletin, 20-2 (1995), p. 255-259.

$4 \quad$ It mak gebruk wan het proefschrift wan B.P. Vermetten, De vrijheid van geweten, en fundamented rechtsprobleem, Arahem 1989. Zie ook R. Bost, Recensie in Tijdschrift voor Privaatrecht 1990 . p. 1$495-1511$ 
Na het verval van de Griekse polis lijken Romeinse denkers zich in twee tegengestelde richtingen van de polisfilosofie af te keren. Aan de ene kant richt het denken zich op kosmopolitisch universalisme. Aan de andere kant richt het zich op het individu, op het innerlijk. Door het inzicht dat je iemand per definitie niet kunt dwingen om te geloven komt vrijheid van geloof als beginsel tegenover geloofsdwang te staan. Door een sterke oriëntatie op innerlijke autonomie blijft een uiterlijke sfeer van vrijheid voor de individuele mens echter nog buiten beeld. Daarbij kont dat ook het beginsel van geloofsvrijheid zelf restrictiever wordt toegepast naarmate de vervolging van het christendon wegens vermeende staatsvijandigheid afneemt. ${ }^{5}$

Tegen de tijd dat het christendom de status van Romeinse staatsgodsdienst heef bereikt, heeft er een koerswijziging plaatsgehad in de christelijke theologie. Doordat het criterium voor objectieve waarheid gezocht wordt in de kerk, worden argumenten vóbr wrijheid en tégen dwang op het terrein van de religie ondergraven. De kerk is niet meer een geestelijke gemeenschap van gelovigen op basis van vrijwilligheid. Ze is "een machtig, hiërarchisch georganiseerd en door de staat beschernd instituut." De middeleeuwse Westeuropese samenleving wordt letterlijk een "respublica christiana". In een eenheid wan kerk en Rooms-Duitse rijk symboliseren paus en keizer samen de politiek-religieuze eenheid van de christenen.

Met de opkomst van zich onahankelijk beschouwende nationale vorsten brokkelt vanaf de dertiende eeuw het Rooms-Duitse imperium af. Pleidooien woor tolerantie en gewetensvitjheid worden steeds sterker. Door geloofsverdeeldheid, dynastiek en adelijk machtsstreven en de overtuiging de (eigen) enig ware godsdienst met alle middelen te moeten beschermen, wordt West-Europa vanaf de tweede helft van de zestiende eeuw het toneel van bloedige godsdienstoorlogen. Om hieraan een einde te maken worden pogingen gedaan om in een nieuwe politieke orde met juridische regelingen tot een zekere mate van vreedzame coëxistentie van verschillende godsdiensten te komen. De eerste regeling op dit gebied is het verdrag dat bekend staat als de Augsburgse religievrede (1555). Dit verdrag erkent de rooms-katholieke en de lutherse confessie en verbiedt de roomse en lutherse landsheren van het Duitse rijk elkaar tegen hun geweten in tot een van deze religies te dwingen. De vrijheid van godsdienstkeuze wordt geformuleerd als gewetenswrijheid van de vorst. Zijn onderdanen moeten hun vorst in zijn keuze volgen of uitwijken.

De Augsburgse religievrede geeft voeding aan de idee van cen soevereine stat die niet (meer) als hoofddoel heeft het handhaven van waarheden, maar hel waarborgen van een vreedzame politicke orde. De primaire staatstaken liggen in deze visie niet op religieus, maat op wereldlijk terrein. Het belang van eenheid van religie moet wijken als het herstel van die eenheid niet zonder grote schade aan het algemeen belang (orde, vrede, welvaart) te bereiken is. Om de orde en rust te kunnen waarborgen moet de vorst als een neutrale, soevereine instantie boven twistende religiepartijen staan. 


\section{Hoofdstuk 8}

Naast en waak in samenhang met de politiek-pragmatische pleidooien voor (partiële) secularisatie van de staat en voor tolerantie ten aanzien van godsdienstige minderheden worden in de zestiende en zeventiende eeuw principieel-ethische argumentaties ontwikkeld voor religieuze verdraagzaamheid. In aan tijd en omstandigheden aangepaste vorm zijn deze argumentaties meestal gebaseerd op de klassieke bezwaren tegen geloofsdwang. Een spiritualistisch motief grijpt terug op de eerder besproken ethiek van het innerlijk. Verder wordt opnieuw een beroep gedaan op het argument dat het geloof slechts in vrijheid aanvaard kan worden. Origineel is een derde argument: de onaantastbare waardigheid vain het individuele geweten. Dit argument ligt ten grondslag aan de formulering van de vrijheid van geweten op het terrein van de religie als individueel recht van de mens. Eerdere argumenten kunnen geen individueel recht funderen ondat afwijzing van geloofsdwang daarin niet gebaseerd is op iets individueels, maar op het wezen van kerk en geloof

Vooronderstelling in de tot nu toe geschetste redenering is nog steeds dat de objectieve (geloofs)waarheid in beginsel gekend kan worden. Maar er ontstaat ook cen tendens van relativering van de waarheid. Het argument dat geen enkele wereldlijke instantie in staat is te bepalen wat de waarheid is en dus geen bevoegdheid heeft iemand omwille van zilin geloofsovertuiging te veroordelen en te straffen wint steeds meer aan kracht. Daarmee zijn de belangrijkste praktische en theoretische voorwaarden vervuld om de vrijheid van geweten te kunnen formuleren als een recht. Praktisch is de eenheid tussen kerk en stat verbroken. De staat heeft zich tegenover de religie geëmancipeerd. Theoretisch is het argument van dwang ter wille van geloofswaarheid weggevallen. Deze ontwikkelingen scheppen de ruimte waardoor een bepaald aspect van het geweten - in het geweten kont de mens in aanraking met God - nu als argument voor de gewetensvrijheid kan gaan fungeren. Deze opvatting ligt al besloten in het gewetensconcept dat sinds de oudheid dominant is. Nu zijn de noodzakelijke condities vervuld om het geweten op grond van godsverbondenheid een eigen sfeer, juridisch geformuleerd als vrijheidsrecht, te kwnnen en te moeten toekennen.

In de loop van de tijd wordt in verdragen, edicten en verdedigingsverbonden aan de aanhangers van de belangrijkste godsdiensten gaandeweg vrijheid van geweten toegekend. De Unie van Utrecht (1579) is op dit gebied een primeur. De in artikel XIII Unie van Utrecht gewaarborgde vrijheid van geweten kan beschouwd worden als de eerste positivering van de idee der mensenrechten in een subjectief vrijheidsrecht. ${ }^{7}$ Niet een autonome grondslag, waarvan hier nog geen sprake is, maar de theonome grondslag van het geweten blijkt de juridische formulering van de vrijheid van geweten alls cerste mensenrecht mogelijk to hebben gemaakt.

In de tijd vóór de Franse revolutie worden politieke verlangens die te maken hebben met zekerheid van leven en eigendom, met vrijheid van godsdienst en meningsuiting, met beginselen van een eerlijke procesgang en met bescherming tegen wreedheden in de strafrechtspleging steeds meer gemeengoed. Sterker nog, men gaat daar rechten in zien die 
aan een ieder mens als zodanig behoren toe te komen. Interiationaal gezien is dat nog niet zo duidelijk bij het tot stand komen van de Unie van Utrecht in 1579 en ook niet bij de Engelse Bill of Rights van 1688. In Bills of Rights die tot stand komen in de onafhankelijkheidsstrijd van Jonge Amerikaanse staten tegen Engeland, is dat wél duidelijk. De eerste Amerikaanse Bill of Rights is die van Virginia van 1776. Deze en latere Amerikaanse Verklaringen hebben grote invloed op de Franse Verklaring van de Rechten van de Mens en de Burger van 1789 en via deze op alle latere verklaringen van rechten van de mens."

Artikel 2 van de Franse Verklaring van 1789 luidt: "Het doel van iedere politieke vereniging is het handhaven van de natuurlijke en onvervreendbare mensenrechten. Deze rechten zijn vrijheid, eigendom, veiligheid en het verzet tegen onderdrukking."10 De Franse verklaring staat bij de vestiging van de Bataafse Republiek model voor de Hollandse Proclamatie der rechten van den Mensch en van den Burger van 1795. Artikel 5 wan de Hollandse Proclamatie is echter van eigen bodem. Als een vernieuwing van de in 1579 in de Unie wan Utrecht vastgelegde vrijheid van geweten op het gebied van de religie staat in dit artikel: "dat ieder Mensch het recht heeft, om God zoodanig te dienen als hij wil, of niet wil, zonder daarin op eenigerlei wijze gedwongen te kunnen worden."

In de Unie van Utrecht van 1579 en in de Hollandse Proclamatie van 1795 mag de notie van mensenrecht te herkennen zijn, het blijt een interne statelijke aangelegenheid. Pas na de eerste wereldoorlog komt met de oprichting van de Volkenbond ais eerste algemene wereldorganisatie een voorzichtige internationalisering van rechten van de mens op gang. Het streven van de Volkenbond is erop gericht om staatsgrenzen en grenzen van volkeren zo veel mogelijk te laten samenvallen. Dit leidt tot internationale afspraken over de behandeling van minderheden. "Hoewel ook dit afspraken tussen staten waren betroffen deze regelingen in de eerste plaats mensen. Een eerste begin van mensenrechten trad het volkenrecht binnen." "1?

Tijdens de tweede wereldoorlog klinken klemmende pleidooien voor een wereldomvattende regeling op het gebied van mensenrechten. Een bekend voorbeeld van zo'n pleidooi is de boodschap van President Franklin D. Roosevelt wan 6 januari 1941, gericht aan het Congres van de Verenigde Staten van Amerika. De in die boodschap verpakte "Vier

A.A.G. Peters, De emancipatie van de mens. in M.B.W. Bieshewel en C. Dlinterman (red), De rechten wan de mens, Amsterdam 1983, p. 7.22, zie p. 10-11. Peters maki er op attent dat al in de Engelse Magna Charta wan 1215 vier wezentije bestanddelen van de rechen van de mons te onderkennen zijn: de notie wan een forum warvoor zuke rechten verdedigd kunnen worden; een beroep op "hoger tech" dan een bevel van politieke overtheden, een beginsel van wederkerigheid en de nodige feitelijke politieke macht van onderdinen om subjectieve rechten te kumen doorzetten.

9 Peters 1983, p. 11. Zie ook Gerbenzon/Algra 1987, p. 182 v.

10 Over de introductie in de Franse Verklaring van individuele on collecteve zelbeschikking van dr mens, als individu en burger, zie Meij van Bruggen 1989, p. $12 \mathrm{v}$.

1) Gerbenzon/Algra 1987, p. 184. De auteurs verwijzen naar de Amsterdanse dissentatic van W.J. Goslinga De Rechten van den Mensch en Burger (1936). 


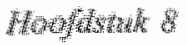

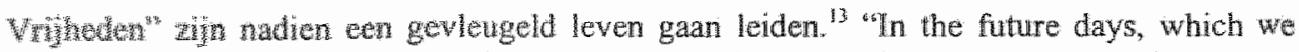

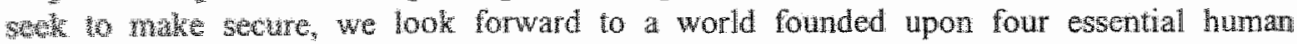
fredtows. The ritst is freedon of spech and expression - everywhere in the world. The sacoud s.s fredtom ar every person to worship God in his own way - everywhere in the worth. The third is treedom from want - which, translated into world terms, means econome understandings which will secure to every nation a healthy peace life time for its

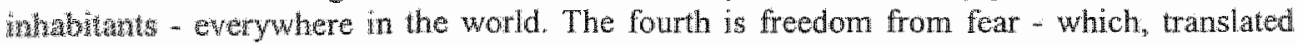
wate world temsers means a worldwide reduction of armaments to such a point and in such a horough fashion that no nation will be in a position to commit an act of physical wgrgession against any neighbour - anywhere in the world. That is no vision of a distinct milnennim. It is a definite basis for a kind of a world attainable in our own time and generation. ${ }^{314}$ In dexe historische boodschap worden niet alleen klassieke vrijheidstechtem genoemu, waronder de gewetenswrijheid op het gebied van de religie. Ook sociale rechten vatu de mens worden daarin voorgesteld als aspecten van vrijheid.

In 1945 komt het Handvest van de Verenigde Naties (VN) tol stand. Daarin worden enkele bepathingen opgenomen over het bevorderen door de VN van universele eerbied voor en inachtneming van de rechten van de mens en de fundamentele vrijheden voor allen, zonder onderscheid naar ras, geslacht, taal of godsdienst. In 1948 wordt in de Algemene vergadering van de WN de eerder als politieke intentieverklaring dan als juridisch document bedoelde Universele Verklaring van de Rechten van de mens aangenomen. In artikel 1 van de Universele Verklaring staat dat alle mensen vrij en gelijk in wardigheid en rechten geboren worden, dat zij begiftigd zijn met verstand en geweten en dat zij zich jegens elkander in een geest van broederschap behoren te gedragen. Een hernieuwing van de boodschap van de Franse revolutie: vrijheid, gelijkheid en broederschap. Juridisch bindend wordt de gewetensvrijheid daarna in Europees verband gecodificeerd in artikel 9 EVRM. In VN-verband gebeurt dat in artikel 18 IVBPR.

\section{Zet "oeverloosheid" van het geweten het vrijheidsbeginsel opzij? ${ }^{15}$}

In zijn proefschrift betreffende de gewetenswrijheid als fundamenteel rechtsprobleem komt Vermeulen tot de conclusie: "het geweten heeft elke "aanwijsbaarheid" verloren. Hel heeft net enkel de grenzen van zijn oorspronkelike terrein, de religieuze, private sfeer reeds lang overschreden. Zijn actieradius is zelfs onbeperkt geworden: het is "oeverloos" geworden." Hij betoogt dat het geweten niet alleen theoretisch, maar ook feitelijk oeverloos is

13 Nar deze morele uitgangspunten verwijst de "Four Freedoms Award" wan de Roosevelt Stiching. Oudpremier $R$. Lubbers onving deze onderscheiding op 3 april 1995 voor zijn insparningen in de jaren rachtig om eem einde te makan an de Koude Ootlog.

14 Th.C. van Boven, De wolkenechtelike bescheming wan de godsdienstvrijhed, proefschrift Leiden. Assen 1967. p. 67. verwijst vaor dit citat naar Commager. Hemry Steele, Documents of American History (3rd ed, 1946), p. 634.

15 De "aewerloosheidsthese" wordt verdedigd door Vermenlen, 1989. De bespreking in deze paragraaf is cen verkorte weergave van mijn commentar op deze these in Bost 1990. Vermenlen 1989, p. 123. 
geworden. Factoren als toenemende overheidsinterventies op terremen die woorheen tot het private domein behoorden, diferentiatie op godsdienstig terrein, polikisering en individua lisering van het geweten spelen hierbij een rol. Naast het voor de hand liggende anarchieargument - angst voor opheffing van de beschermende functies van het recht bij onbegrensde exteme gewetenswrijheid - werkt Vermeulen een principieel juridisch argument uit tegen een algemeen recht op gewetenswijheid: omdat het geweten geen concrete verschijningsvorm beeft is adequate clausulering van de gewetenswrijheid principieel onmogelijk.

Een analyse van de artikelen 9 EVRM en 18 IVBPR leidt Vemeulen tot de bevinding dat deze slechts de innerlijke gewetensvrijheid bestrijken, niet de externe wrijheid van geweten. Hij betoogt dat de daarin opgenomen bepalingen over de vrijheid van godsdienst an levensovertuiging objectief-restrictief uitgelegd moeten worden. In zijn betoog gat het om de rol die de vrijheid van geweten in het bestaande Nederlandse rechtssysteem speelt en kan spelen. Vooral op het laatste (kán spelen) is mijn bezwaar gericht in de visie van Vermeulen kan het geweten slechts die rol in het rechtssysteem spelen waarvoor de wetgever op deelterreinen vooraf een overzichtelijk kader cueesert. Mijn bezwaar ziet niet op het pragmatisch-juridisch miweau van regelgeving of rechtspraak ter effectuering van een fundamenteel menselijke waarde als de vrijheid van geweten. Mijn bezwaar ziet op het principieel-juridisch niveau van de erkenning van die fundamentele waarde zélf. Het keert zich tegen een visic waarin deze principiele algemene erkenning - waaran in een democratische rechtsstaat ook overheidsorganen gebonden zijn - geacht wordt nutteloos te zin, ondat ze in de rechtspraktijk "onmogelijk" zou zijn.

Is het geweten inderdad oeverloos geworden? Laat de ontwikkeling van het Westerse denken over gewetensdwang en gewetenswrijheid niet de geleidelijke uilkristallisering zien van universele menselijke waarden als algenene inspiratiebronnen voor gewetensvol handelen? Kan de Universele Verklaring van de Rechten van de Mens, waamaar Vemeulen in de openingspassage van zijn studie verwijst, niet gezien worden als neerslag van deze eeuwenoude ontwikkeling op het gebied van menselijke (gewetens)warden? Mij lijkt dat de Unversele Verklaring beschouwd kan worden als eerste poging in de geschiedenis wan de menseljke soort on te komen tot uniwersele politick-juridische matstaven voor gewetensvol handelen. Dat geld juist ook, nu algemeen menselijke waarden geleidelijk aan losgekoppeld zijn of worden van de christelijke religie als inspiratiebron. De door Vementen beschroven schijnbar bescheiden plaats die de gewetensvrijheid in oris huidig rechtssysteen inneent kan dan verklaard worden vanuit de gedachte dat de wrijheid van geweten juridisch gezien een soort restcategorie is. In samenhang met nieuwe inzichten in de samenleving word deze restcategorie telkens nader gedifferenticerd en geconcretiseerd. De kern van morele vrijheid blijf daarbij het uitgangspunt.

Voeding voor" de hier voorgestelde visie vind ik bij Vermeulen zelf, waar hij verwijst mar fundamentele rechtsbeginselen, "basiswatden als de democratie on het respect voor de rechten van de mens" die in onze rechtsorde differentiatie tussen verschillende gewetensmotteven toelaten. "De redelijkheid van een dergelijke differentiatie vlocit voort uilt de taak wan de staat genoende beginselen te waarborgen, hetgeen impliceent dal hij niet hoeft en 


\section{Hoofdstuk 8}

soms zelfs niet dient te wijken voor (gewetens)principes die deze beginselen witshiten." Impliceert dit niet dat het de taak van de staat is on ók of juíst het beginsel van gewetenswriheid als grond- of mensenrechbeginsel te waarborgen? Een beginsel dat zich niet oplost met het steeds weer nader concretiseren. En komen, mét respect voor de rechten van de mens, niet tevens algeneen-nenselijke voedingsbronnen en daraan gekoppeld lets als een universele "oever" voor de uit deze bromen voorkomende stromingen in zicht? Ik denk aan stromingen als werdragzam humanisme, pacifisme en een ecologische wedespolitick.

Vermeulen onderschrift mijn betoog op het punt van het telkens nader differentiërn en juridisch concretiseren van de vrijheid van geweten. ${ }^{18}$ Mar hil ziot daarin eerder een bevestiging dan een weerlegging van de in zijn proefschrift verkondigde stelling dat de wrijheid wan geweten en onmogelijk recht is. Het is en blift volgens hem goed mogelijk het beroep op het geweten en de vrijheid van geweten te zien als een belangrijke morele inspiratiebron om te komen tot de formulering en eebiediging van grondrechten. Historisch kan het beginsel wan de vrijheid van geweten zelfs gezien worden als de "moeder der grondrechten." Door de positivering van een aantal gewetensrelevante vrijheden is de juridische taak wan de gewetenswrijheid wolgens Vermeulen echter witgehold. Ik ga er darentegen van wit dat de wijheid van geweten als rechisbeginsel niet woor juridische witholling vatbar is. Integendeel, ze blijft steeds vatbaar voor nadere juridische concretisering.

Als uitgegaan wordt van erkenning wan vrijheid van geweten als beginsel van mensenrecht, dan dient juridische beperking van deze gewetenswijheid zich niet aan als "ommogelijk", het uitgangspunt van Vermeulen. Juridische beperking dient zich dan aan als "noodzake. lijk" in een democratische samenlewing. Het uitgangspunt voor het mogelijk maken wan gewetensconform levensgedrag of voor de erkenning van gewetensbezwaren is dan, niet zoals bij Vermeulen de praktische hanteerbaarheid bezien vanuit het rechtssysteem. Hot uitgangspunt is dan respect woor en bescherming van de gewetensvrijheid als fundamentele rechtswarde, in een evenwichtige afweging met en bescherming van andere basiswaarden.

Vermeulen stelt dat er zwaarwegende gronden zijn om an te nemen dat artikel 9 lid 1 EVRM uitshitend de unterne gewetensvrijheid bestrijkt. Anders dan de tegengestelde visic, die in rechtspratak veelal wordt ingenomen, moodzaakt dit standpunt er niet toe om toevlucht te nemen tot onaanvaardbare beperkingsmethoden, aldus Vermeulen. ${ }^{20} \mathrm{Hij}$ onderbouwt zinti standpunt met argumenten van historische, systematische en rechtslogische ard. Ik beperk de bespreking hier tot het in de ogen van Vermeulen doorslaggevend

17 Vermevilen 1989, p. 233.

18 B.P. Wemeulen, Wie bepalt de reikwijde van de grondrechten? Preadvies, Handelingen van de vereniging voor wijsbegeerte van het recht, R\&R $1992 /$, p. 16-46, p. 31-32.

19 Vermeulen 1992 , p. 32, verwijst naw G. Jellimek, Die Eiklärung der Menschen- und Bürgerrechte (1895) in R.Schnur (Hrs.), Zur Geschichte der Erklärung der Menschenrechte, Darmstadt 1964.

20 Vermeulen 1989, p. 184 . 
rechislogisch argument: de onmogelijkheid van ongeclausuleerde externe gewetensvrijheid. ${ }^{21}$

Ik deel de mening van Vermeulen dat de beperkingsgronden van artikel 9 lid 2 EVRM waaronder het criterium openbare orde - uitsluitend van toepassing zijn op uitingswrijheid, niet op innerlijke wrijheid. Dat blijkt duidelijk uit de tekst van dit artikellid: "De vrijheid zijn godsdienst te belijden of overtuiging tot uitdrukking te brengen kan aan geen andere beperkingen zijn onderworpen dan die bij de wet zijn voorzien en in een democratische samenleving noodzakelijk zijn in het belang van de openbare velligheid, voor de bescherming van de openbare orde, gezondheid of goede zeden of voor de bescherming van de rechten en vrijheden van anderen." Ook ben ik het met Vermeulen eens dat het gezien verdragstekst en verdragssystematiek niet toegestaan is de in artikel 9 lid $\mathbb{1}$ EVRM opgesomde vrijheden buiten artikel 9 lid $2 \mathrm{om}$ te beperken. In de visie van Vermenlen dwingt dit rechtslogisch tot de conclusie: "Daar de vrijheid van geweten in artikel 9 lid 1 EVRM niet aan beperkingen onderworpen is, kan en mag zij enkel op het forum internum betrekking hebben."

In de volgende benadering vervalt het in Vermeulens redenering ijzersterk rechtslogisch argument, de onmogelijkheid van ongeclausuleerde externe gewetenswrijheid. In de overgang tussen het eerste en het tweede gedeelte van artikel 9 lid I EVRM meen ik stof voor deze benadering te vinden. Voor de duidelijkheid volgt hier de tekst van artikel 9 lid 1 EVRM integraal: "Een ieder heeft recht op vrijheid van gedachte, geweten en godsdienst; dit recht omvat tevens de vrijheid om van godsdienst of overtuiging te veranderen, alsmede de vrijheid hetzij alleen, hetzij met anderen, zowel in het openbaar als in zijn particuliere leven zijn godsdienst of overtuiging te belijden door de eredienst, door het onderwijzen ervan, door de praktische toepassing ervan en het onderhouden van de geboden en voorschriften."

Vermeulen spreekt over "twee verschillende groepen van vrijheidsrechten, waarbij de ene categorie (de vrijheid van gedachte, geweten etc.) enkel op het form internum, de andere categorie (de godsdienstige en levensbeschouwelijke uitingsvrijheid) op het forum externum betrekking heef." ${ }^{, 23}$ Het onderscheid tussen louter innerlijke geesteswrijheid en uiterlijke handelingsvrijheid wordt volgens de auteur enigszins "verdoezeld" door de frase dat het eerdergenoende recht tevens het laatstgenoemde omvat ("includes resp. "implique" in de authentieke Engelse en Franse verdragsteksten), 2.24 Ten onrechte suggereert dit volgens hem dat de vrijheid van gedachte, geweten en godsdienst mede betrekking heeft op het forum externum.

\footnotetext{
21 Voor cen bespreking wan de andere argumenten verwijs ik naar Bost 1990, p. 1508-1509. De strekking van vemeulens redenering ten anzien wan antikel 9 EVRM is ook wh topassing op artikel 18 IVBPE

22 Vermeulen 1989, p. 191.

23 Vermeulen 1989, p. $185-186$.

24 Vermeulen 1989, p. 186
} 


\section{Hoofdstuk 8}

Zou het kumnen dat het bindteken - omvat, includes, implique - ook verhelderend werkt? Ik doel op het feit, dat dit bindteken nevenschikkend seculiere en religieuze noties in een doorgaande lijn betrekt op innerlijke en uiterlijke vrijheden. Is de overgangspassage zo gezien zowel een verbinding tussen het religieuze en het seculiere geestesleven als tussen het rijk van de geest en dat van het sociaal handelen? In deze visie drukt artikel. 9 lid 1 EVRM niet "twee verschillende groepen vrijheidsrechten" uit, maar innerlijke vrijheden en daarvan te onderscheiden, maar niet of nauwelijks te scheiden uiterlijke vormen van diezelfde vrijheden, zoals ze zich in de samenleving manifesteren. Zo gezien worden in artikel 9 lid 1 EVRM innerlijke aspecten van de geesteswereld naar hun uiterlijke aspecten samengevat in een religieuze stroming onder de noemer "godsdienst" en een seculiere stroming onder de noemer "overtuiging". De seculiere externe gedachten- en gewetenswrijheid is dan onder le brengen in uitingswormen van "overtuiging". Dat komt overeen met de in artikel 9 lid I. EVRM genoemde "praktische toepassing ervan" (van godsdienst en overtuiging). Zo gezicn kan naar ik meen met recht gepleit worden woor een interpretatie van artikel 9 lid 1 EVRM die rekening houdt met de secullarisatie van het gewetensbegrip, maar het daarom nog niet als "overloos" beschouwt.

De tegenwerping dat de externe gewetenswrijheid niet af te leiden is uit artikel 9 lid 1 EVRM, juist omdat ze als het ware "opgeslokt" wordt door de vrijheid van overtuiging, snijdt in de door mij voorgestelde interpretatie geen hout. Deze tegenwerping gaat wit van een visie die niet alleen het interne gewetensbegrip, maar ook de exteme uitingsvormen van levensovertuiging zuiver formeel benadert, als uitsluitend objectief herkenbaar aan "hoe" de overtuiging zich manifesteert en niet mede aan "wat" ze tot uitdrukking brengt. ${ }^{25}$ Als aangenomen wordt dat externe gewetenswrijheid in artikel 9 lid 1 EVRM inderdaad onder de noemer van uiting wan (gewetens)overtuiging te brengen is, dan komt deze externe gewetensvrijheid per definitie onder het beperkingsregime van artikel 9 lid 2 EVRM te vallen, waaronder het beperkingscriterium openbare orde. Daarmee vervalt in déze redenering het in Vermeulens redenering ijzersterk argument van rechtslogische aard tégen het erkennen van externe gewetenswrijheid.

De historische ontwikkeling van de gewetenswrijheid én de oeverloosheidsthese van Vermeulen illustreren de achtergrond van de voorrangspasitie van klassicke vrijheidsrechten ten opzichte van sociale mensenrechten. Klassieke vrijheidstechten die weinig of niets kosten (interne gewetensvijheid) of die vanuit overheidsoptiek juridisch goed beheersbaar zijn (externe godsdienstwrijheid) kunnen gemakkelijker juridisch erkend worden dan sociale rechten waarvan gevreesd wordt dat ze een "onmogelijke" zorgverplichting op de stat leggen. Met ontkrachting van de oeverloosheidsthese en de daarop gebaseerde "onmogelijkheid" wan principiële erkenning van externe gewetenswrijheid wordt een mogelijk juridisch obstakel voor vrijheid als leidend beginsel van mensenrecht uit de weg geruimd. Dat is zeker van belang waar het hier om het geweten als morele kern van de mens en om gewetenswrijheid als "moeder der grondrechten" gaat.

25 Dat een formele, "objectief-restrictieve" interpretatie wat het "objectieve" betreft nogal betrekkelijk kan zijn lieb ik proberen te illustreren an het woobeeld dat Vemenlen geeft in de zaak Arrowsmith woor de Europese Conmissie. Zie Vermeulen 1989, p. 202 \%; Bost 1990, p. 1510. 


\section{Drie beginselen van mensenrecht als hulpmiddel bij het opheffen van de twee- deling in klassieke en sociale mensenrechten?}

"De ondeelbaarheid en onderlinge afhankelijkheid van alle rechten van de mens staan iegenwoordig buiten kijf. $\mathrm{Zij}$ zijn een fundamenteel beginsel van de benadering van de rechten van de mens door de Verenigde Naties en behoren tot de normatieve grondslag van het tegenwoordige internationale recht inzake de rechten van de mens." ${ }^{226}$ Theoretisch sluit deze doctrine aan bij de in het eerste deel van deze studie weergegeven reconstructie van subjectieve rechten als woorwaarden voor een legitieme rechtsorde. ${ }^{27}$ Praktisch lijkt de doctrine van de ondeelbaarheid en afhankelijkheid van alle rechten van de mens nog nauwelijks vertaling te vinden in de rechtspraktijk. Dat de tweedeling van mensenrechten in afzonderlijke politieke en sociale componenten onvoldoende recht doet aan de bescherming van de menselijke persoon in haar totaliteit leidt Van Boven naar ik meen terecht af "wit de keuzes die in latere codificaties zijn gemaakt aangaande bescherming van bepaalde categorieën mensen: vrouwen, kinderen, migranten, inheemse volkeren. In al deze codificaties zijn de politieke en sociale grondrechten bij elkaar gebracht omdat juist voor de kwetsbare mens de beschikking over politieke mondigheid en sociale bescherming een levenswoorwaarde is voor een menswaardig bestaan." 28

Bij het hanteren van de klassieke vrijheidsrechten van het EVRM is via het Europees Hof voor de bescherming van de rechten van de mens te Straatsburg de leer van de negatieve en positieve staatsverplichtingen ontstaan. ${ }^{29}$ Deze leer kan gezien worden als een poging tot een gedeeltelijke vertaling van de doctrine van de ondeelbaarheid en onderlinge afhankelijkheid van alle rechten van de mens in de rechtspraktijk. Als een probleem dringt zich dan op dat het onderscheid tussen negatieve en positieve verplichtingen soms "werkelijk verwarrend" kan zijn. ${ }^{30}$ Laten we deze materie wat nader bekijken aan de hand van een analyse van de aard van positieve verplichtingen uit het EVRM. ${ }^{31}$

De traditioneel als klassieke mensenrechten aangeduide rechten uit het EVRM gaan uit "van de aan de Franse en Amerikannse revoluties ontleende idlee dat ieder individu een bepaalde mate van vrijheid toekomt warin de staat, of ieder met de staat gelijk te stellen verband, niet mag treden. (..) Naast, en in contrast met, deze klassieke grondrechten staan de sociale grondrechten. Saciale grondrechten leggen aan de staat een verplichting op om actie te ondernemen om het individu bescherming te bieden of on anderszins woordelen woor het individu veilig te stellen. Het beeld dat aldus ontstaat is er een van twee soorten

Zie hidst, 3, par. 2.

Van Boven 1994, p. 140-141.

Zie herover Canoline J. Forder, Positieve verplichtigen in het kader wan het Europees Verdrag tor bescherming wan de rechten van de mens en de fundamentele vribheden, in NJCM-Bulletin $17-6$ (1992), p. $611-637$.

Forder 1992, p. 619

31 Fonder 1992, p. $616 \mathrm{v}$. 


\section{Hoofdstuk 8}

constitutionele rechten: van sociaal-grondrechtelijke en klassiek-grondrechtelijke aard." In het verlengde van de hir geschetste tweedeling ligt en onderverdeling in positieve (sociale) en negatieve (klassieke) rechten met daaraan gekoppelde positieve en negatieve statsverplichtingen.

In de leer van positieve staatsverplichtingen uit het EVRM worden positieve (sociale) rechtein en dito staatswerplichungen gewomd uil rechten waarvan oorspronkelijk aangenomen werd dat ze uitsluitend en negatief (klassiek) karakter hadden. In een onderzoek van de jurisprudentie van het Hof in Straatsburg naar de reikwijdte van positieve verplichtingen in het kader van het EVRM komt Forder tot de conclusie dat het moeilik kan zijn positieve en negatieve verplichtingen van elkaar te onderscheiden. Soms blijkt de karakterisering vrij willekeurig te gebeuren terwijl het aanmerken wan een verplichting als positief kan resulteren in een geringere bescherming van het desbetreffende belang. Forder toont overtuigend aan "dat positieve en negatieve verplichtingen niet van dien aard zijn dat zij als twee uitersten tegenover elkar staan, maar dat ze eerder twee parallelle, complementaire en elkarr soms overlappende categorieen van bescherming vertegenwoordigen." reden pleit zij ervoor, positieve verphichtingen zoveel als redelijkerwijs mogelijk is naar analogie met negatiewe te ontwikkelen.

Ik zou nog een stap verder willen gaan. IK zou willen pleiten voor het bekijken van alle staatsverphchtingen op het gebied van grond- en mensenrechten als (varianten van) positieve verplichthingen. Met deze benadering wil ik niet alleen de ondeelbaarheid en onderlinge afhankelijkheid van alle rechten van de mens accentueren. Ik denk dat deze benadering ook kan helpen voorkomen dat de klassieke wrijheidsidee en daarmee de idee van de rechtsstat in de kern bedreigd wordi. Dat laatste kan gebeuren als de klassieke vrijheidsidee overwoekerd wordt door handelend optreden wan de overheid bij het verwezenlijken van sociale grondrechten. ${ }^{34}$

Bij de door mij voorgestelde benadering kan de an het einde van het eerste deel van deze studie ter sprake gekomen typologie van verplichtingen van staten goede diensten bewijzen. Het gaat om de verplichtingen 1) "to respect", 2) "to protect" en 3) "to fulfil", 35 Wat nu en negatieve verplichting word genoemd kan dan getypeerd worden als de (positieve) verplichting "to respect". Het positieve aspect van deze verplichting is de positieve grondhouding van respect die geeist wordt voor ieders persoonlyke whijheid. Deze grondhouding brengt de verplichting mee om zich te onthouden van iedere ongerechtvardigde immenging in de private en publieke vrijheidssfeer van de rechtsgenoten. Deze benadering van positicf respect voor vrijheid spoort met een leidende positie voor het mensemrechtelikk beginsel vrijheid, in onverbrekelijke samenhang met de beginselen trouw entin zorg.

32 Fodder 1992, p. 616, verwijst naar Van der PotDonner. Handboek van het Nederlands statsrecht, bewcrkt door L. Puakke, J.L. de Reede en G.J.M.van Wissen, Zwolle 1989, p. 236.

33 Forder 1992, p. 637 .

34 Forder 1992, p. 623 signaleert deze tendens onder verwitzing nar C.A.J.M. Kortmanin, De Grondwetsherzieninge, Deventer 1987, p. 42.

35 Zie hfdst. 4, par. 6, met verwijaing mar Coomans 1994. 
De verplichtingen om te respecteren, te beschermen en te verwezenlijken kunnen alle drie ap dezelfde manier vastgesteld worden als het Straatsburgse Hof nu de negatieve verplichtingen vaststelt. Op dat punt komt mijn voorstel overeen met dai van Forder, die betoogt dai het Hof bij positieve verpiichtingen hetzelfde "twee-trappenproces" moet toepassen als bij negatieve verplichtingen. "Aldus moet het Hof zich allereerst toeleggen op de vraag naar de strekking van het belang van het individu, om zich vervolgens te wijden alan een beschouwing van de vraag of er doelstellingen of andere factoren zijn die een beperking van de reikwijdte van het recht rechtwaardigen." 360

De eerste trap van het genoemde "iwee-trappenproces" heeft steeds in eerste instantie te maken met een aspect van vrijheid, een kern van morele wrijheid die in alle rechten van de mens zit. Op deze eerste trap is dat wrijheidsaspect direct betrokken op de strekking van het belang van het individu. Als aspecten van actieve zorg (in de varianten beschermen en verwezenlijken) daar in deze eerste stap ondeelbaar mee samen hangen, dan moeten die in ieder geval juist de kern van het vrijheidsaspect tot zijn recht laten komen.

Op de tweede trap spelen de beginselen vrijheid en zorg hun rol op een ander niveau. Op deze trap is staatszorg primair betrokken op algemene aspecten van vrijheid voor ieder binnen de rechtsorde als geheel. Onder de noemer van die algemene vrijheid vallen alle rechten van de mens. In het concrete geval hoort daaronder óok het beschermen van de kern van de individuele vrijheid die in het proces (op de eerste trap) aan de orde is. Het integer instaan voor bescherming van het in verhouding tot andere algenene belangen vaak zeer kwetsbaar individueel belang typeert hier de praktisch bemiddelende rol van het beginsel trouw. Het speeli die rol niet achtereenvolgens, op de beide niveaus van het weetrappenproces. Het speelt die praktische rol óbk bij het oversiappen van de ene theoretisch af te bakenen trap op de andere. Het beginsel trouw moet in een cloorlopend proces borg staan voor een integere bescherming van ieders individuele vrijheid als algemeen belang. Als het twee-trappenproces vanuit deze optiek kan worden toegepast, dan werken drie beginselen van mensentecht inderdaad als hulpmiddel bij het vertalen van de doctrine van de ondeelbaarheid en onderlinge afhankelijkheid van alle rechten van de mens in de rechtspraktijk.

\section{Staatsverplichtingen: ütbanning van rassendiscriminatie tegenover respect voor uitingsvrijheid van journalisten}

In het vorige hoofdstuk heb ik de uitbreiding en aanscherping geschetst van Nederlandse strafbepalingen met het oog op het bestrijden van discriminatie." In de discussie over rassendiscriminatie via de media draait het om de strafrechtelijke aansprakelijkheid van de journalist. "Deze problematiek doet zich met name in die gevallen voor, waarin een journalist, ogenschijnlijk onbecommentarieerd, witlatingen wars opruiend of (voor een groep mensen) beledigend karakter uit overwegingen van nieuwswaarde aanhaalt met de intentie

37 Hedst 7. par. 5. 


\section{Hoofdstuk 8}

on zijn publiek te informeren over het verschijnsel van rechts-extremisme. ${ }^{138}$ Is deze journalist strafbaar of gaat hij vrij-uit vanwege de vrijheid van het publieke debat in de media?

Een witspraak van 23 september 1994 van het Europees Hof voor de Rechten van de Mens gaat over een geval dat zich in Denemarken heeft afgespeeld rond de journalist Olaf Jersild. ${ }^{37}$ Het Hof heeft deze zaak behandeld nadat Jersild in Denemarken tot in hoogste strafrechtelijke instantie wervolgd en veroordeeld is wegens medeplichtigheid aan belediging van een groep mensen wegens hun ras in een televisieprogramma. Volgens de Deense rechters moet het belang van de bescherming tegen rassendiscriminatie in de zaak Jersild zwarder wegen dan dat van de vrijheid van meningsuiting van de journalist, betreffende zaken van openbaar belang. De Deense cassatierechter komt tot de slotsom dat het uitzenden van de opvattingen van de extreem-rechtse jongeren voor de joumalist niet geboden was, "temeer niet daar Jersild van de uitlatingen geen afstand heeft genomen én daar aan de uitlating elke nieuwswaarde ontbreekt." ${ }^{340}$ Volgens het Hof in Straatsburg daarentegen had Jersild wrij-uil moeten gaan. Het Hof oordeelt dat Denemarken met het strafrechtelijk veroordelen wan Jersild artikel 10 EVRM (vrijheid van meningsuiting) heeft geschonden.

De eerste trap van het in de vorige paragraaf genoemde twee-trappenproces levert hier geen probleem op. De vrijheid van meningsuiting staat in het proces voorop. Dat de weroordeling van de journalist een inbreuk op die vrijheid inhoudt, is tussen partijen onbetwist. Het Hof kan in één adem doorlopen van de eerste naar de tweede trap: "It is common ground that the measures giving rise to the applicants case constituted an interference with his right to freedom of expression. ${ }^{* 41}$ Evenmin staat tussen partijen ter discussie dat deze inbreuk bij de wet is voorzien en een legitien doel dient, overeenkomstig de eisen van artikel. 10 lid 2 EVRM. Het legitiem doel van de desbetreffende Deense strafbepaling komt overeen met het in artikel 10 lid 2 EVRM genoemde doelcriterium: bescherming van de goede naam of rechten van anderen. Resteert overeenkonstig de laatste eis van artikel 10 lid 2 EVRM de vraag of de inbreuk op de vrijheid van meningsuiting door middel van een veroordeling van de journalist "noodzakelijk" is in een democratische samenleving. Dat is de vraag waar het in de zaak Jersild tegen Denemarken om gaat.

Bij de vraag nar de noodzaak van de veroordeling van Jersild betrekt het Hof de in cerdere uitspraken uitgezette lijn. Aan de ene kant staat de belangrijke rol die de media in cen demoeratische samenleving hebben. Aan de andere kant staan de "plichten on verantwoordelijkheden" die de vrijheid van meningsuiting overeenkomstig het tweede lid

38 Ianssens 1995, p. 124, verwijst in dit verband nar de artikelen $131,137 c_{0} 137 \mathrm{e}, 261 \mathrm{cn} 266$ Sr. Ter illustatie van het probleem wijst hij op recente commotie over een documentaire over Duitse neonazi"s, whatin extreem-rechtse jongeren ruim de kans kregen on hun visie over Auschwitz te geven. EHRM 23 september 1994. Series A 289 (Jersild $*$ Denemarken). Over deze uitsprak uitgebreid Janssans 1095. p. $125 \mathrm{~F}$. Zie voor de belangrijkste rechtsoverwegingen uit het arrest NICM-Bulletin $20-2(1995)$, p. $167-175$.

40 Janssens 1995, p. 126

41 Rechisoverweging ar. 27, NICM-Bulletin 1995, p. 168. 
wan antikel 10 EVRM met zich brengt met het oog op de in dat lid genoemde beperkingsgronden. Met het oog op "plichten en verantwoordelijkheden" var de joumalist ten aanzien van de reputatie en de rechten van anderen ziet het Hof als een belangrijke factor of het onderwerp als geheel, objectief gezien, geacht kan worden als doel te bebben gehad het propageren van racistische gezichtspunten en ideeen. 2 Het Hof komt tot de slotsom dat Jersild in het kader van het publieke debat een integer gebruk heeft gemaakt van zin whijheid wan meningsuiting.

Vertaald naar de Nederlandse strafrechtspraktijk is het in het vorige hoofdstuk besproken artikel $137 \mathrm{e} \mathrm{Sr}$ hier relevant. Deze strabepaling verbiedt het verspreiden of openbaar maken van voor een groep mensen wegens thun ras beledigende uitlatingen, thnders dan ten behoeve van zakelijke berichtgeving. In een Nederlandse variant van de zaak Jorsid kan de verwijzing in artikel $137 \mathrm{e} \mathrm{Sr}$ naar zakelijke berichtgeving de Nederlandse rechter behulpzaam zijn bij het vaststellen van de "plichten en verantwoordelikheden" van joumalisten in het kader van de bescherming van mensen tegen discriminatie via de strafwet." In de Deense strafbepaling komt zo'n bestanddeel betreffende zakelijke benichtgeving niet voor. In de rechtspraak van het Hof in Straatsburg speelt de taak van journalisten in het kader van het publieke debat een belangrijke rol, ongeacht de inhoud van nationale bepalingen. Aan de andare kant speelt het nakomen door de mationale staten van verplichtingen uit het VN-verdrag inzake de uitbanting van alle vormen van rassendiscriminatie een belangrijke rol. Dit verdrag heeft een op het EVRM aarvullende werking ${ }^{\text {at }}$

In Nederland is niet alleen in artikel $137 \mathrm{e} \mathrm{Sr}$ een verwijzing nat het publieke debat te winden. Volgens het derde lid van artikel $261 \mathrm{Sr}$, over smaad en smaadschrift, gat de dader vrij-uit als hij te goeder trouw heeft kunnen aannemen dat het te laste gelegde waar was en dat het algemeen belang de telastlegging eiste. Janssens oppert naar ik meen terecht dat de term "te goeder trouw" in artikel 261 lid 3 ST conrespondeert met de cerder besproken "plichten en verantwoordelijkheden" van de joumalist in het kader van het publieke debat over aangelegenheden van openbaar belang." De term "te goeder troww" in artikel 261 lid $3 \mathrm{Sr}$ bevestigt een juridische bemiddelende rol wan het mensenrechtelijk beginsel trouw ten opzichte van de beginselen wrijheid en zorg. Trouw is her de verbindende factor tussen indwiduele vrijheid van meningsuiting ton dienste van publicke communicatie en overheidszorg voor het vrijwaren van mensen tegen rassendiscriminatie.

Het begrip openbare orde speelt in deze paragraaf mee via de strafbepaling van antikel $137 \mathrm{e} \mathrm{Sr}$. In de internationale context van artikel 10 lid 2 EVRM is dere nationale strafbepaling een bij wet woorziene noodzakelijke beperking wan de vrijheid var meningswing Als nationale strafbepaling valt arikel $137 \mathrm{e} \mathrm{Sr}$ onder de noemer openbare orde. Zoals eerder besproken staat dit artikel in het Nederlandse Wetboek van Strafrechl onder Janssens 1995, p. 133 \%. komt tot de conclusie dat de Nederlandse rechtspraktijk "Jersidd" op de voet volgt. in theorie en prakijk, $3 e$ druk. Nijmegen 1990, p. $587-588$. 


\section{Hoofdstuk 8}

de titel Misdrijven tegen de openbare orde. ${ }^{46}$ Als beperkingsgrond volgens artikel 10 lid 2 EVRM valt dit misdrijf tegen de openbare orde niet onder het criterium openbare orde, maar onder bescherming van de goede naam of de rechten van derden. Juist door het onopvallende ervan speelt openbare orde hier een rol die naar ithoud een algemeen inzetbaarheid van het begrip openbare orde, georiënieerd aan drie beginselen van mensenrecht, bevestigt. Wat functies ten aanzien van mensenrecht betreft heeft het begrip openbare orde hier via artikel $137 \mathrm{e} \mathrm{Sr}$ tegelijk een beschermende (tegen rassendicriminatie) en potentieel beperkende functie (vrijheid van meningsuiting). Nu deze samenloop al meerdere malen in deze studie is geconstateerd, komt de vraag op naar een overkoepelend functiebegrip dat de diverse deelfuncties van het openbare orde begrip ten aanzien van mensenrecht omvat. Daarover gaat de volgende paragraaf.

\section{Een universele bemiddelende functie van het begrip openbare orde ten aanzien wan mensen recht}

Artikel 29 van de Universele Verklaring van de rechten van de mens luidt: "1. Een ieder heeft plichten jegens de gemeenschap, zonder welke de vrije en volledige ontplooing van zijn persoonlijkheid niet mogelijk is. 2 . In de uitoefening van zijn rechten en vrijheden zal een ieder slechts onderworpen zijn aan die beperkingen, welke bij de wet zijn wastgesteld en wel uilsluitend ter verzekering van de onmisbare erkenning en eerbiediging van de rechten en vrijheden wan anderen en om te voldoen aan de gerechtvaardigde eisen van de moraliteit, de openbare orde en het algemeen welzijn in een democratische gemeenschap." Zoals hier, als doelcriterium voor de noodzakelijke beperking van mensenrechten, is het begrip openbare orde een algemeen bekende verschijning in mensenrechtenverdragen en in nationale wetgeving inzake grond- en mensenrechten. In deze beperkende functie is het bij voorbeeld te vinden in de tweede leden van de artikelen $8 \mathrm{t} / \mathrm{m} 11$ EVRM (betreffende recht op privacy, wrijheid van geweten en godsdienst, vrijheid van meningsuiting en recht van vereniging en vergadering) en in overeenkomstige artikelen in het IVBPR.

In de Nederlandse tekst van het EVRM zijn vier varianten wan het begrip openbare orde als beperkingscriterium te vinden: in het belang van de openbare orde (in artikel 6 , betreffende het recht op een eerlijk en openbaar proces), voor de bescherming van de openbare orde (artikel 9 lid 2), voor de handhaving wan de openbare orde (artikel 2 lid $y$ van het bij het EVRM behorende Vierde Protocol, betreffende vrijheid van beweging) en tenslotte het voorkomen van wanordelijkheden (tweede leden van de artikelen 8, 10 en (1). ${ }^{47}$

462 ie theflst. 7, par. 5 .

47 A.M.F. LoofDonker, E.M. Peeters en P.H. van der Tang-van Loenen, De openbare orde: een te nemen horde? Kantekeningen bij de wijze warop de Nederlandse wetgever ongaat me! het begrip "openbare orde" als doelcriterium woor de beperking van grond- en mensenrechten, in NJCM-Bulletin 19-5 (1994). p. $503-518$, p. 506 . 
Via de authentieke Engelse en Franse teksten yan het EVRM proberen Loof-Donker ea. duidelijkheid te krijgen over de betekenis van de verschillende formuleringen, ${ }^{4}$ Daarbij wijzen zij er om te beginnen op dat de Franse term ordre public niet dezelfde betekenis heeft als de Engelse term public order. De eerste komt uit de Engelse conmon-law traditie, de tweede heeft een continentaal-Europese achtergrond. ${ }^{\text {s9 }}$ De onderzoekers komen tot een driedeling in betekenisgeving. Als het meest ruime openbare orde begrip omvat het Franse ordre public de fundamentele beginselen van een positief rechtsstelsel. De Engelse term public order is minder ruim en komt overeen met het ordelijk verloop van het gemeenschapsleven of met de afwezigheid van publieke wanorde. In een derde, meest enge betekenis komen het Franse a la defence de l'ordre en het Engelse for the prevention of disorder overeen met het ontbreken of voorkomen van wanordelijkheden.

Aan de hand wan deze driedeling onderzoeken Loof-Donker e.a. zes recente Nederlandse wetten die als grond voor wetgeving (handhaving van) de openbare orde hebben. ${ }^{50} \mathrm{Zij}$ komen tot de conclusie dat de opvatting van de Nederlandse wetgever slechts in twee van de zes gevallen strookt met de interpretatie zoals die af te leiden is uit de terminologie en de Europese jurisprudentie onder het EVRM. In de meerderheid van de gevallen blijkt de nationale wetgever een ruimer openbare orde begrip te hanteren dan in het corresponderende artikel van het EVRM gebeurt. In enkele van de onderzochte gevallen geeft de wetgever zo'n ruime invulling aan de bescherming van de openbare orde "dat niet slechts (de op zich al zeer ruime) bescherming van fundamentele rechtsbeginselen van de rechtsorde (ordre public) daar onder valt, maar ook iets dat lijkt op "het handhaven en beschermen van een maatschappelijk gewenste situatie."

Loof-Donker e.a. spreken van een "minimalistische houding" van de Nederlandse wetgever ten aanzien van grond- en mensenrechten "die geen recht doet aan het beginsel dat de vrijheidsrechten, als grondbeginselen, extensief moeten worden opgevat en dat de op die rechten toegestane beperkingen, als uitzonderingen, restrictief moeten worden uitgelegd." ${ }^{\text {52 }} \mathrm{Zij}$ beweren niet dat deze minimalistische houding ten aanzien van grond-en mensenrechten, hier synoniem, maatgevend is voor alle produkten van de Nederlandse wetgever. Wel signaleren zij een tendens watrin de wetgever steeds meer geneigd is "ruimhartig" gebruik te maken van "het belang van de openbare orde" als beperkingsgrond. "Hierbij lijkt de wetgever te vergeten dat grondrechten speciale bescherming genicten, ondat ze een halt behoren toe te roepen aan al te slagvaardig optreden van de overheid en een werhoogde rechtsgelding hebben, omdat zo een onlosmakelijk onderdeel

Loof-Donker e.a. 1994, p. 506 y. Zie ook J.G.C. Schokkenbroek, De openbare orde als beperkingsgrond woor de wrigheid wan meningsuiting, NYCM-Bulletin $11-1(1986), p, 3-22$ Loof-Donker ea. 1994, p. 506-507 verwijzen naar Van Dijk/wan Hoof 1990, p. 643 en Schokkenbroek 1986

50 Loof-Donker ea. 1994, p. 509. w. onderzoken de Wet veboden rechispersonen, de Wet openbare manifestaties, de Geneentewet, de Wet identificatieplicht, de Wet bestijding schijnhuwelijken en de Wel getuigenbescherroing. 
vormen wan onte rechtsorde. ${ }^{353}$

De gesignaleerde beperkende tendens komt overeen met de volgende constatering van de onderzockers Gerbranda en Kroes. "De vele jaren onderzoek naar de doorwerking van de grondrechten in de Nederlandse rechtspraktijk hebben ons in het eindrapport tot de conclusie geleid dat de wetgever zich vaker de rol van beperkter dan van beschermer heeft toegemeten." "Si Uit onderzoeken als de hier genoemde is in onderling verband op te maken dat de Nederlandse wetgever in de rol van beperkter van mensenrechten met het begrip openbare orde een vertrouwd, universeel instrument in handen heeft. Hoe staat het met de beschermende functie van het begrip openbare orde?

Evenals voor een beperkende functie is ook voor een universele beschermende functie van het openbare orde begrip een basis te vinden in de Universele Verklaring van de rechten wan de mens. Ik denk aan artikel $28 \mathrm{UV}$. Volgens dit artikel heeft een ieder "recht op het bestaun van een zodanige maatschappelijke en internationale orde, dat de rechten en vrijheden, in deze Verklaring genoemd, daarin ten volle kunnen worden verwezenlijkt." In hun onderlinge samenhang kunnen de artikelen 28 en 29 UV niet alleen model staan voor universele beperkende, maar ook voor beschermende en bemiddelende aspecten van het politiek-juridisch gebruik van het begrip openbare orde ten aanzien van mensenrechten. Ik stel voor, de verschillende aspecten onder de overkoepelende noemer van een bemiddelende functie te brengen zonder de afzonderlijke functie-aspecten uit het oog te verliezen.

Met "bemiddeling" als overkoepelende functie van het begrip operbare orde ten aanzien van mensenrecht bcoog ik de ondeelbaarheid en onderlinge afhankelijkheid van alle mensenrechten te accentueren. Wat vanuit het ene gezichtspunt een beperking is kan wanuit een ander gezichtspunt neerkomen op bescherming van hetzelfde of een ander mensenrecht. En wat op het micro-niveau van direct betrokkenen als beperkend overkomt kan vanuit het macro-niveau wan de rechtsgemeenschap als noodzakelijk beschermend gezien worden mot het oog op behoud van gelijkwaardige vrijheid voor ieder binnen die gemeenschap. In de vorige paragraaf hebben we uitgebreid een voorbeeld van een en ander bekcken. In dát licht stel ik voor de algennene inzetbaarheid van het begrip openbare orde ten aanzien van mensenrecht als "bemiddeling" aan te duiden. In deze functie geeft inhoudelijk het mensenrechtelijk beginsel vrijheid in zijn individuele en gemeenschappelijke dimensies de toon aan, in onderlinge samenhang met de beginselen trouw en zorg. Dat geldt óok voor sociale mensentechten waarin feitelijk de component zorg op de voorgrond komt. En het geldt óok waar bij openbare orde het functie-aspect beperking van mensenrecht op de voorgrond staat. De praktische zin van zo'n universele bemiddelende functie wan het begrip openbare orde ten aanzien wan mensenrecht komt in de slotparagraaf van dit hoofdstuk aan de orde in het kader van het Europees Gemeenschapsrecht. Als voorwerk probeer ik in die context in de volgende paragraaf te laten zien dat het zin heef de doctrine van de ondeelbaarheid en onderlinge afhankelijkheid van alle rechten van de mens

Loot-Donker e.a. 1994 , p. 518.

Tjeiske Gerbranda en Mariame Kroes, De wetgever en de mensenrechtem: beschermer of beperker? Enkele aatiekeningen mar annleiding wan het Grondrechten Evaluatie Onderzok, WJCM-Bulletin. 19-5 $(1994)$, p. 4654481, p. 465 . 
te vertalen mar de rechtspraktijk.

\section{Mensenrecht in de context van Europees Gemeenschapsrecht}

De Europese Gemeenschap (EG) is als samenwerkingsverband op economisch gebled niet direct als zelfstandige verdragspartij juridisch gebonden aan mensenrechtenverdragen. De lidstaten van de EG zijn wél direct gebonden aan mensenrechtenverdragen. Het Hof van Iustitic van de EG in $\mathbb{L}$ uxemburg heeft dat probleen al in 1969 aangepakt door mensenrechten bimen de EG afdwingbaar te maken als ongeschreven algemene beginselen wan gemeenschapsrecht. ${ }^{55}$ Het Verdrag van Maastricht (1992) betreffende de Europese Unie lijkt in artikel F lid 2 een stapje verder te gaan: "De Unie eerbiedigt de grondrechten, zoals die worden gewarborgd door het op 4 novenber 1950 te Rome ondertekende Europees Verdrag tot bescherming wan de rechten van de mens en de fundamentele wrijheden en zoals zij uit de gemeenschappelijke constitutionele tradities van de Lid-Staten woortwloeien, als algemene beginselen van het gemeenschapsrecht." In dit wrikel F" wordt het EVRM als rechtstreeks bindend voor de Europese Unie beschouxd. Onder de Slotbepalingen van hetzelfde Europese Unieverdrag wordt echter in artikel L bepaald dat de bevoegdhend van het Hof van Justitie niet van toepassing is op de inleidende bepalingen van het Verdrag, waaronder artikel $F$.

De Witte noemt de geschetste regeling én van de vele eigenaardigheden van het Europese Unieverdrag. "Enerzids wordt de bescherming van grondrechten belangrijk genoeg geacht om in éen wan de inleidende bepalingen van het werdrag genoend te worden; anderzijds wordt aan het Hof van Justitie de mogelijkheid ontnomen om die zelfde grondrechten ook werkelijk afdwingbaar te maken." Dit soort eigenaardigheden maakl het Furopees Gemeenschapsrecht tot een interessant verkenningsgebied met het oog op de doctrine van de ondeelbaarheid en onderlinge afhankelijkheid van alle mensenrechten. Ik giet cen korte verkenning in de vorm van een commentaar op het artikel "Over staatstaken, sociale grondrechten en mensenrechten" wan Elies Steyger. ${ }^{57}$

Wooropgesteld: ik deel de algemene conclusie van Steyger dat mensenrechten over coht belangrijke dingen gaan war we zumig op en mee moeten zijn. Waar hat mij hier on gat is Steygers mening dat deze zunigheid emee gediend is als sociale grondrechten, ook in

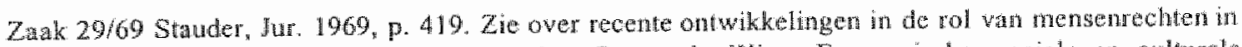
de rechtsorde wan de Europese Gemeenshap Bruno de Witte Economische sociale cr culturele rechen: de rol van de Eutopese Gemeenschap, in A.P.M. Coomans a.a. (red.). De hoenemente betekens wan economische, sociale en culurele mensentechter, Leiden 1994, p. 8-22, p. I5 v. met literaturverwijzingen.

56 De Witte 1994, $\mathrm{p} .16$, makt wat de gromdrechtenbescheming in de Enopese Unie betreften onder

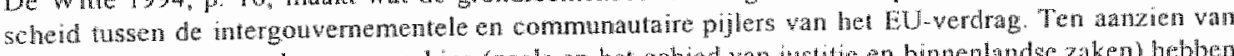

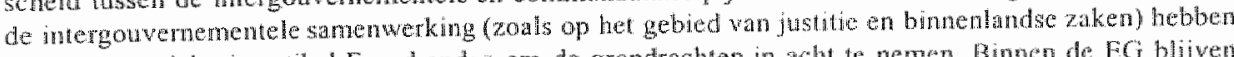

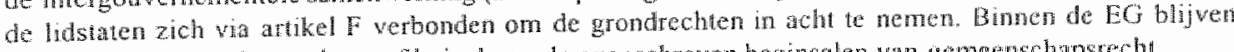
grondrechen evenals wooheen afdwingbar al ongeschreven beginselien wan geme exsohapsech. 


\section{Hoofdstuk 8}

het kader van de Europese Gemeenschap, opgevat worden als staatstaken en niet als grondof mensenrechten. Die mening deel ik niet. Door mijn opvatting tegenover die van Steyger te stellen denk ik aannemelijk te maken dat het zinvol is om de doctrine van ondeelbaarheid en onderlinge afhankelijkheid wan alle mensenrechten te vertalen naar de rechtspraktijk.

Steyger zet de toon met haar opvatting dat grond- en mensenrechten uit hun aard antidemocratisch zijn, of het nu gaat om klassieke of om sociale rechten. Waar ik op theoretisch niveau uitga van een intern verband tussen democratie en mensenrecht staat deze opvatting haaks op de mijne. Steyger bedoelt het volgende. "Du moment dat we (meestal op democratische wijze) hebben geaccepteerd dat grondrechten niet geschonden mogen worden hebben we de neiging om ze zodanig vast te leggen, dat aan dat principe niet meer getornd kan worden, ook niet wanneer de democratische verhoudingen in een land zodanig veranderen dat de ideeën over wie voor de bescherming in aammerking komt, wijzigen." ${ }^{158}$

De neiging om het principe dat grondrechten niet geschonden mogen worden praktisch onaantastbaar te maken lijkt mij gezond. Het is precies de bedoeling van grondrechten dat ze niet geschonden worden. Dat hoeft er in een democratische samenleving naar ik meen niet atan in de weg te staan dat veranderende idleeën over wie voor de grondrechtelijke bescherming in aanmerking komt geeffectueerd worden. Bij wijziging van inzichten over de reikwijdte van grondrechtelijke bescherming kan het principe zélf van de onschendbaarheid van grondrechten onverkort overeind blijven. Overigens vindt ook Steyger zelf het vasthouden aan het principe van onschendbaarheid een goede zaak, als het orn klassieke grondrechten gaat, waarvoor zi.j de term mensenrechten reserveert. Onverkorte bescherming van (klassieke) mensenrechten ziet $z \mathrm{ij}$ terecht als bescherming tegen machtsmisbruik. Over sociale grondrechten denkt zij anders. De gewenste bemoeienis van de staat met gebieden die in het algemeen geformuleerd zijn als sociale grondrechten wil zij onder de noemer staatstaak brengen en bij voorkeur niet als sociaal grondrecht of mensenrecht. definiëren. Waarom niet?

Als een nadeel van het formuleren van sociale grondrechten als grondrecht ziet Steyger een dearuit voortvloeiende verplichting tot staatsbemoeienis. Door staatsbemoeienis verplicht te stellen door middel wan sociale grondrechten wordt in haar ogen onrecht gedaan "alan het zelfregulerend vermogen van de samenleving en aan het democratisch vermogen te beslissen op welke wijze wij bemoeienis wensen van de staat." ${ }^{\text {"w9 }}$ Als een ander nadeel ziet zij de mogelijkheid dat sociale grondrechten gefonnuleerd als grondrecht individueel afdwingbaar worden. Zij vreest de neiging van het verabsoluteren van grond- of mensenrechten en hel daardoor uit het oog verliezen van de positie van derden. Op de genoemde nadelen ga ik nader in aan de hand van twee voorbeelden die Steyger geeft van sociale grondrechten die door het EG-verdrag beschermd en geëffectueend worden: het recht op gelijke beloning voor gelijk werk van mannen en vrouwen in het arbeidsproces en het recht op veilige en gezonde werkomstandigheden. Een derde door haar genoemd voor-

59 Steyger 1994, p. 26. 
beeld, gelijkberechtiging van EG-migranten, komt in de volgende paragraf aan bod. ${ }^{\text {to }}$

Als werkdefmitie verstaat Steyger onder sociale (en culturele) grondrechten rechten "die de bescherming van groepen van mensen op het oog hebben op gebieden die witeindelijk voor die groepen van belang zijn:" Volgens deze defintie beschouwt zij van de drie genoemde voorbeelden alleen het recht op veilige en gezonde werkomstandigheden onomstreden als een sociaal grondrecht. Het recht op gelijke beloning van mannen en vrouwen voon gelijk werk is wolgens haar een klassiek grondrecht (een mensenrecht), ook al stat het in een werdrag dat economische, sociale en culturele rechten vastlegt, het IVESCR (artikel 7 (a-i). Over het derde voorbeeld, gelijke behandeling van EG-migranten, zegt Steyger alleen dat men daarover kan twisten. Laten we met het enige door Steyger als mensenrecht aangemerkte vooibeeld beginnen.

Dat het recht op gelijke beloning van mannen en vrouwen bij de arbeid geen sociaal grondrecht, maar een (klassiek) mensenrecht is, baseert Steyger op het recht on in gelijke situaties gelijk behandeld te worden. "En hoewel het gelijkheidsbeginsel lange tijd door zowel wetgever als werkgevers niet werd geacht gelijke beloning te onvalten, neemt dit niet weg dat we het hier over een mensenrecht en niet over een socianl grondrecht hebben. Het simpele feit dat de (nationale) wetgever het werkgevers toestond om wel te discrimineren was een schending van een mensenrecht. Het was eigenlijk schandalig dat de EEG er voor nodig was dil recht te zetten." beloning voor gelijk werk om een mensenrecht gaat. Dit mensenrecht is in artikel 23 lid 2 UV in 1948 als volgt geformuleerd: "Een ieder, zonder enige achterstelling, heeft recht op gellik loon voor gelijke arbeid." In het oprichtingsverdrag wan de Europese Economische Gemeenschap in 1957 is dit recht in artikel 119 erkend.

In de tweedeling van Steyger lleidt de constatering dat het om een (klassiek) mensenrecht gaat er toe dat het dan miet tegelijk ók om een sociaal grond- of mensenrech kan gaan. In min optick gaat het om het integreren van klassieke en sociale aspecten in een en hotzelfde mensenrecht. Voor mij gaat het hier in de kern om gelijkwaardige vrijheid voor ieder ten aanzien van het deelnemen aan het arbeidsproces. Achterstelling op grond van geslacht is niet te rechtvardigen. Waar het zelfregulerend vermogen van de veije arbeidsmarkt kennelijk te kort schiet on deze achaterstelling op te heffen komt op basis van het mensenrecht een zorgverplichting op de stat te liggen om deze vorm wan discriminatu uit te bannen. In deze gedachtengang is Steygers constatering dat het hier om een klassick mensentecht gaat een bevestiging van ondeelbaarheid van klassieke en sociale aspecten wan dit mensenrecht.

Het tweede voorbeeld: recht op veilige en gezonde werkonustandigheden. Steyger ziet dit niet als een mensenrecht. Het is in haar termen een in zichzelf niet zonder meer afdwingbaar sociaal grondrecht. Het legt een verplichting op de staat matregelen te nemen om 


\section{Hoofdstuk 8}

daarvoor te zorgen. Steyger benadrukt dat de bemoeienis van de staat met arbeidsomstandigheden niet voortgevloeid is uit de erkenning van dit recht als sociaal grondrecht. ${ }^{2} \mathrm{Het}$ is in de vorige eetw ontstaan uit de veelal hemeltergende omstandigheden waarin mensen moesten werken en de gruwelijke ongelukken die daarbij gebeurden. In de verschillende Europese staten besefte men dat ongebreideld liberalisme en kapitalisme kennelijk niet genoeg zelfregulerende mechanismen bezat om dit soort excessen te voorkomen en dus werd tot wetgeving om de vrijheid van ondernemers op dit punt in te dammen besloten. Nogmaals dit had niets met grondrechten, of zelfs maar met democratie te maken. Ook in niet democratische landen kan men wan het begin van deze eetw arbeidsbeschermende wetgeving zien ontstaan, zij het in de laatste landen langzamer dan in de eerste."

Toegegeven, dit stukje geschiedenis heeft niets te maken met in die tijd bestacnde afdwingbare sociale grondrechten. Anders zouden de mensen die destijds onder mensonwaardige omstandigheden moesten werken juridisch een poot gehad hebben om op te staan. Maar heeft dit stukje geschiedenis ook niets te maken met het ontstaan van grondrechten op sociaal-econonisch gebied? Dat lijkt onwaarschijnlijk. Sterker nog, ik denk dat het ontstaan wan wat nu economische en sociale grond- en mensenrechten genoemd worden alles te maken heeft met het besef van onreclit door een of andere vorm van onmenselijkheid, achterstelling, machtsmisbruik. "In elke situatie, in elke groep en samenleving is het realiseren van menselijke waardigheid een opgaaf die tegen de druk van omstandigheden, obstakels, machten, priwileges en structuren in moet worden waargemaakt." de historische ontwikkeling van arbeidsrecht niet mensenrech-in-ontwikkeling? Ik denk van wel.

Uitgangspunt is het zelfregulerend vermogen van de samenleving. Als dat kennelijk te kort schiet ontstaat het besef dat staatszorg geboden is voor het keren wan onrecht. Dit besef zellf kan gezien worden in het licht van een rechtsontwikkeling, niet alleen in dat van een politieke ontwikkeling van staatstaken. In de kern gaat het evenals bij gelijk loon voor gelijk werk om gelijkwaardige vrijheid (hier vrijwaring van onveilige en ongezonde werkomstandigheden) en daaraan gekoppelde zorg voor ieder ten aanzien van het deelnemen aan het arbeidsproces. Mijn opvatting dat het in beide gevallen om een mensenrecht gaat strookt met artikel 23 UV. Daarin is het recht op rechtvaardige arbeidsvoorwaarden als mensenrecht opgenomen in het eerste lid en thet recht op gelijk loon voor gelijke arbeid in het tweede lid.

Vanuit de contractswrijheid kan de ontwikkeling van sociaal recht op het terrein van de aibeid beschouwd worden als het geleidelijk wettelijk beperken van een ongebreidelde machtspositic van ondernemers tegenover arbeiders als maatschappelijk zwakkere partij. In dit verband duikt het begrippenpaar openbare orde en goede zeden op. In werband met het arbeidscontract dat geacht wordt in strijd te zijn met de openbare orde en de goede zeden

03. Steyger 1994, p. 25 verwijst naar haar boek Medezeggenschap bij veiligheid en gezondheid, de Europese regelingen, Deventer 1990, p. 204-213. Peters 1983, p. 7. 
denk ik aan een eerder geciteerde passage wan Van der Ley. Contracten "waarbij leven, gezondheid en eerbaarheid in gevar zijn van arbeiders en werkrouwen, gelijk bij zekere chemische industrieèn (loodwit en chloorkalk-fabrieken) worden geldig geacht." Daarbij zuet het er volgens Van der Ley (in 1899) naar unt dat of "over niet lange tijd, zowel de geldwoeker als het uitzuigingscontract doorlopend geacht worden in strijd te zijn met de goede zeden, of dat er wettelijke regeling omtrent dit onderwerp zal ontstan. "*to

In VN-verband is het recht op veilige en hygienische werkomstandigheden thans met zoveel woorden vastgelegd in artikel 7(b) IVESCR en in Europees verband in artikel 3 ESH. Zoals we eerder hebben gezien blijf de juridische afdwingbaarheid van de un deze verdragen erkende sociale mensenrechten achter bij de afdwingbaarheid van klassieke mensenrechten. Wat dat betreft sluit de opvatting van Steyger aan bij de realiteit. De ontwikkeling van sociale grondrechten in Exropees Gemeenschapsverband bekijkt zij dan ook met enige argwaan. Met de Europese Akte van 1986 heeft de Europese Gemeenschap een expliciete bevoegdheid gekregen om bindende maatregelen te nemen op het terrein van de veiligheid en gezondheid op het werk. Met De Witte denk ik dat het er met het daaruit woortwloeiende pakket richtlinnen op lijkt "dat vanuit de Gemeenschap cen belangrijke impuls is uitgegaan voor de verbetering van de toestand in een aantal landen. Daardoor levert de $\mathrm{EG}$ een bijdrage tot de effecturering van het recht op "velige hygienische arbeidsomstandigheden dat in artikel 7 (b) van het IVESCR wordt genoend on in artikel 3 wan het ESH iets explicieter wordt beschreven." Wat mij betreft past ook deze rechtsontwikkeling in een visie op arbeidsrecht als mensenrechtmin-ontwikkeling.

De door Steyger gesignaleerde nadelen van het formuleren van sociale grondrechten als grondrecht vallen naar ik meen weg bij het aannemen van de ondeelbaatheid en onderlinge a fhankelikheid van alle mensentechten. Het is dan niet nodig om uit te gaan wan verplichte staatsbemoeienis, ook als daar geen behoefte aan is, zodra een sociaal grondrecht als grond- of mensenrecht wordt geformuleerd. Aan de hand wan de eerder besproken typologie van staatsverplichtingen kan ten aanzien van elk grond-of mensenrecht aan de hand van de feitelijke situatie telkens vastgesteld worden of volstaan kan worden met respecteren, dan wel dat er sprake dient te zijn van beschemen of van verwerkelijken.

Volgens Steyger wordt de stat door het creéren van een social grondrocht een macht op zichzelf, vour zover het om het effectueren wh dit grondrecht gaat zij geen er de wookeur an dat do staat op sociaal gebied zelf uitmaakt in hoeverte zij moet ingrijpen. "Bevalt ons de mate warin de staat dat doet niet, dan hebben wij de nogehikheid of, via de volksvertegenwoordiging de regering tot een andere houding te dwingen, of indien zij dit niet doet een andere volksvertegenwoordiging te kiezen die het beter doet." ${ }^{\circ}$ Mij lijkt dat de staat juist een macht op zichzelf wordt door het accepteren van staatstaken op social gebied die miet teruggevoerd kunnen worden tot grondrechten. 


\section{Hoofdstuk 8}

Ik versta onder een werkende democratie méér dan het terugfluiten of wegstenmen van niet bevallende regeerders of parlementariërs. Kenmerk van een democratische rechtsstaat is dat niet alleen de burgers, maar ook de staat onderworpen is aan het recht. Daaruit vloeit woot dat het bestuur als administratieve macht niet gerechtigd is zelf uit te maken in hoeverre het op sociaal gebied wenst in te grijpen. Staatstaken die betrekking hebben op fundamentele menselijke vrijheden en daarmee verbonden behoefte aan zorg, zowel op politiek als op economisch, sociaal en cultureel gebied, dienen gebaseerd te zijn op rechten van (groepen) mensen. En omdat het om rechten gaat, is in mijn opvatting van een werkende democratie niet alleen parlementaire controle, maar ook de mogelijkheid van rechterlijke controle op de rechtens juiste graad van staatsbemoeienis geboden. In tegenstelling tot staatstaken houden afdwingbare grond- en mensenrechten de weg naar de rechter open.

De rechter is de aangewezen instantie on grond- en mensenrechten via een eigentijdse interpretatie tot hun recht te laten komen, waar de wetgever achterblijft of het bestuur te kort schiet. Als staatstaken de plaats innemen van sociale grondrechten in plaats van daarop gebaseerd te zijn, wordt de rechterlijke macht als in een democratische rechtsstaat essentieel onderdeel van een systeem van checks and balances buiten spel gezet. En dat terwijl we het erover eens zijn dat de staat als uitoefenaar van macht aan grenzen gebonden moet worden.

Het ontkrachten van grondrechten en het daarmee buiten spel zetten van de rechter is geen goede remedie tegen het feit "dlat grondrechten, zowel sociale als klassieke de neiging hebben zó uit te breiden ten voordele van de goed articulerende, redelijk gefortuneerde mens, dat degenen voor wie ze echt geschreven zijn, wel eens vergeten worden." Met het onthouden van basale sociale rechten aan mensen voor wie die rechten echt bedoeld zijn, omdat er door anderen wel eens misbruik van gemaakt zou kunnen worden, zijn de sociaal zwakkeren niet gediend. Het voortdurend in het oog houden dat grond- en mensenrechten precies gericht zijn op het beschermen van de vrijheid van leven wan zwakkeren in de samenleving lijkt een betere remedie. Bij het alert zijn daarop kan het besef van ondeelbaarheid en onderlinge afhankelijkheid van alle mensenrechten behulpzaam zijn. Dat geld ook voor de ondeelbartheid en onderlinge aflankelijkheid van drie beginselen van mensenrecht.

\section{Openbare orde in de context van Europees Gemeenschapsrecht}

Als cen zelfstandige regionale rechtsorde heeft de EG een eigen openbare orde begrip. ${ }^{70}$ Maar de EG heeft ók te maken met openbare orde opvattingen in andere internationale rechtskringen en met nationale openbare orde begrippen van de lidstaten. Daardoor is Europees Gemeenschapsrecht niet alleen een interessant verkenningsgebied met het oog op mensenrecht, maar ook met het oog op het begrip openbare orde. Ik beperk de verkenning

70 H. Boonk, De openbare orde als grens van het vaij verkeer in de EEG, Alphen a.d. Rijn 1977. 
Wier tot het derde in de vorige paragraaf genoemde voorbeeld van een grond- of mensenrecht, de gelijkberechtiging wan EG-migranter.

Als gezegd laat Steyger het ten aanzien van gelijkberechtiging van EG-migranten bij de opmerking dat daarover te twisten valt. Ze bedoelt naar ik aanneem dat zowel iets te zeggen valt voor het aamemen van een mensenrecht als voor een socian grondrecht. Alleen al het voonitzicht van $20^{\prime n}$ twist geef volop voeding aan de eercer besproken werwarring over de aard van staatsverplichtingen en daarmee corresponderende reohtsbescherming. Als we haar eigen tweedeling in rechtens afdwingbare mensenrechten en niet rechtens afdwingbare sociale grondrechton volgen, dan hangt de rechtsbescheming voor EG-migranten immers af van de nitkomst van een twist ower de kevze voor éfn van de twee categorieèn. Wat mij betreft is dat een sterk argument tégen zo'n tweedeling en vóót een praktische toepassing van de doctrine van ondeelbaarheid en onderlinge athankelijkheid van alle rechten wan de mens.

Gelijke behandeling van EG-migranten is gebaseerd op artikel 6 van het EG-verdrag dat binnen de werkingssfeer van het verdrag elke discriminatie op grond van nationaliteit verbiedt. Dit artikel maakt geen onderscheid tussen burgers van de Europese Unie en personen met de nationaliteit van derde landen. In de praktijk geldt het recht op gelijke behandeling echter niet voor vreemdelingen uit niet-EG landen, die in een van de lidstaten verblijven. Dat in de communataire rechtspraktijk enkel discriminaties verboden zijn die EG-burgers betreffen noemt De Witte "een zwakke plek in de Europese regelgeving"." Hij vraagt zich af of deze selectieve effectuering van het in artikel 2 , tweede lid van het IVESCR opgenonmen verbod om te discrimineren op grond van mationaliteit tegelijk een schending van dat artikel betekent. Daarbij merkt hij op dat de bevoordeling door de communautaire wetgever van de unieburgers niet dwingend volgt uit de opzet en aard van de Europese Gemeenschap. ${ }^{72}$ Als dat zo is dan kan het structureel achterstellen van personen met de nationaliteit van een derde land bij het effectueren van sociale grondrechten binmen de EG naar ik meen inderdaad worden beschouwd als discrimimatie in de zin van artikel 2 IVESCR.

De achterstelling van "Europese vreemdelingen" wordt terecht beschouwd als een rechtspolitick probleem dat niet langer genegeerd kan worden. ${ }^{3}$ Van Boven noemt dit probleem de "achilleshiel van de Europese Unie" die kritische vragen oproept "in bet licht van de nomen en waarden die wij, buiten unieverband, intemationaal propageren." Bij wijze van toets ten aanzien van een mensenrechtelijk georiënteerd openbare orde begrip probeer ik hierna antwoord te geven op de volgende vraag. Zou in EG-werband het begrip openbare orde in een bemiddelende functie ten aanzien van mensenrecht bij het aanpakken van het probleem wan de "Europese vreemdelingen" een begrijpelijke on zivvolle juridische rol kunner spelen? 


\section{Hoofdstuth 8}

Bij het bedenken van een antwoord mag niet vergeten worden dat de EG primair werkt vanuit een economisch perspectief. Dat wil thiet zeggen dat de $E G$ als internationale rechtsorde geen bijdrage levert aan het verwezenlijken van mensentechten. Zo'n bijdrage staat echter niet voorop. Lang geleden heeft het EG-Hof ingestemd met EG-wetgeving die het recht op gelijke behandeling beperkt tot burgers van de EG-landen. ${ }^{75}$ Een goed aanknopingspunt om aan die voorkeursbehandeling voor Unieburgers een einde te maken lijkt de voortgaande effectuering van een Europese ruimte zonder binnengrenzen (artikel B verdrag van Maastricht). In $z 0^{\prime} \mathrm{n}$ open ruimte is geen plaats woor ongelijke behandeling van werlanemers op grond van het al dan niet hebben van de status wan Unieburger.

Stel dat EG-wetgeving achterblijft en het EG-Hof het voortouw zou nemen en zou willen "omgaan". Bij gevallen van ongelijke behandeling van "Europese vreemdelingen" zou het zich kumnen laten inspireren door artikel 2 IVESCR als een van de voedingsbronnen voor ongeschrewen algemene beginselen van Gemeenschapsrecht. Niet alleen het tweede lid, maar met name ook het derde lid van artikel 2 IVESCR kan inspirerend werken. Daarin gaat het over ontwikkelingslanden. Die kunnen, behoorlijk rekening houdend met de rechten van de mens en hun nationale economie, bepalen in hoewerre zij de in het IVESCR erkende economische rechten alan niet-onderdanen zullen waarborgen. Uit het feit dat EGlidstaten niel kunnen doorgaan als ontwikkelingslanden kan afgeleid worden dat binnen de EG géen onderscheid gemaakt mag worden op het gebied van sociale rechten van werknemers naar de maatstaf van Unieburgers en niet-Unieburgers.

Al dan niet op de voorgestelde manier gesterkt door het IVESCR en mogelijk andere inspiratiebronnen zou het EG-Hof kunnen kiezen voor een juridische weg die zowel loopt via algemene beginselen van Gemeenschapsrecht als via het openbare orde begrip in artikel 48 lid 3 EG-verdrag. Artikel 48 EG-verdrag is gericht op vrij verkeer van werknemers binnen de Gemeenschap. Er is sprake van werknemers der Lid-Staten, niet van burgers der Lid-Staten in hun functie van werknemer. Het begrip openbare orde figureert in artikel 48 lid 3 naast openbare veiligheid en volksgezondheid als beperkingsgrond die de lidstaten kunnen hanteren ten aanzien van het vrij verkeer van werknemers binnen de EG. In de jurisprudentie van het EG-Hof zijn de grenzen wan de beperkende bevoegdheid van de lidstaten op grond van het openbare orde begrip in artikel 48 lid 3 EG-verdrag steeds preciezer afgebakend. ${ }^{76}$ Een eerste vereiste in het kader van een conmunautair bepaald openbare orde begrip is dat de lidstaten moeten afgaan op do individuele situatie. Beperkende matregelen op grond van de openbare orde mogen uitsluitend berusten op persoonlijk gedrag van de betrokkene. Dat gedrag moet een werkelijke en genoegzaam ernstige bedreiging voor de openbare orde opleveren on en beperkende maatregel te rechtvaardigen." De bedreiging moet een "fundamenteel belang van de samenleving" aantasten."

76 Zie woor overzichten Boonk 1977; R.H. Lauwars, Het voorbehoud voor de openbare orde als. beperking wan het vije verkeer van personen in de EEG, SEW 12 (1978). p. 829 \%: Sacha Predual, Europese monsenrechtenconventie en EEG-recht vergeleken inzake vreemdelingenrecht, Groningen. 1983. p. $6 \mathrm{v}$

77 Zak 36/75, Rutili, Jur. 1975, p. 1232

78 Zaak 30/77. Boucheau, Jur. 1977, p. 2015. 
Daarbij mag geen oneigenlijk gebruik gemaakt worden wan het begrip openbare orde. Dat laatste is bijvoorbeeld het geval als redenen van openbare orde worden opgevoerd terwijt het in werkelijkheid gaat om economische belangen van de eigen staat.

Het EG-Hof zou discriminatie van "Europese vreemdelingen" ten opzichte van burgers van de Unie, door EG-wetgeving of wetgeving van de lidstaten, kumen beschouwen als ongerechtvaardigde beperking van het vrij verkeer van werknemers om oneigenlijke redenen van openbare orde. Daarbij zou de vaste jurisprudentie ten aanzien van een restrictieve invulling van het openbare orde begrip in artikel 48 lid 3 EG-verdrag als leidraad kunnen dienen. Ik neem aan dat ook de andere twee doelcriteria, openbare veiligheid en volksgezondheid, niet van toepassing zijn. Het resultaat zou zijn dat groepen mensen op het basale levensterrein van de arbeid niet structureel achtergesteld mogen worden bimen de Europese Unie als internationalle rechtsorde. De juridische kloof ussen burgers van de Unie en andere ingezetenen zou kleiner worden.

In de geschetste redenering schakelt de EG-rechter het openbare orde begrip uit als mogelijke rechtvaardigingsgrond voor het structureel achterstellen van "Europese vreemdelingen". Juist door deze uitschakeling hanteert de EG-rechter in feite een op werkelijk wrij verkeer van werknemers binnen de EG gerichte communantaire notie van openbare orde in cen betekenis van rechtsorde. Zo'n mensenrechtelijk georiënteerd Europees openbare orde begrip zou aansluiting kunnen zoeken bij de notie "ordre public de l'Europe"7" die de Straatsburgse rechtspraak kent. De vraag over een bemiddelende rol voor het openbare orde begrip ten aanzien van mensenrecht kan in het gegeven voorbeeld een positief antwoord krijgen. 1990, Leiden 1990, p. 3-35, p. 11. 



\section{EEN RICHTSNOER VOOR IEDER?}

\section{Inleiding}

Bij het onderzoek in het Nederlandse recht zijn de voornaamste onderzoeksresultaten gaandeweg vergeleken en meegenomen naar het volgende onderwerp. Toch loop ik de besproken onderwerpen in dit slothoofdstuk nog eens kort na, om een totaaloverzicht te krijgen. In deze samenvattende vergelijking (par. 2) wordt van meet af het eindresultaat betrokken: bundeling van deelfuncties van het begrip openbare orde in een universele bemiddelende functie, inhoudelijk georiënteerd aan drie beginselen van mensenrecht. Ter afronding van de houdbaarheidstest van het richtsnoer voor ieder (par. 3) wordt ook het moreel gezichtspunt van alpartijdigheid bij de onderzoeksresultaten betrokken.

Ik heb gespeeld met de gedachte om aan het slot van deze studie het richtsnoer vrij uitgebreid praktisch in te zetten. Daartoe dacht ik per onderzocht deelgebied in het Nederlandse recht het rechtsgehalte van enkele concrete beslissingen te peilen. Achteraf lijkt dat geen goede gedachte. Min of meer terloops zijn in het tweede deel al zoveel testmomenten aan de orde geweest dat de praktische hanteerbaarheid naar ik meen voldoende aannemelijk is geworden. Of en hoe het richtsnoer als hulpmiddel bij ieder ander werkt wordt niet duidelijker naarmate ik de mogelijke werking ervan zelf uitgebreider demonstreer. Voor ieder die het werkelijk als hulpmiddel wil gebruiken lijkt zelf praktisch ermee aan de slag gaan de enig aangewezen weg.

Voor een eenvoudige proef op de som kies ik het tweede Geertruidenberg-arrest, de beslissing van de Hoge Raad die de directe aanleiding tot deze studie is geworden.' De ingangsvraag blijft: is dit recht? (par. 4) Ik sluit deze studie af met een korte speculatieve beschouwing over drie beginselen wan mensenrecht als universeel richtsnoer voor icder in een wereldorde in wording (par. 5).

\section{Samenvattende vergelijking Nederlands recht}

Terugkijkend: bij de opkomst van het begrip openbare orde in het ipr ${ }^{2}$ stelt het in een afwerende functie de rechter in stat om ongewenst vreemd privaatrecht dat volgens de verwijzingsregels toegepast zou moeten worden buiten toepassing te laten, alls "in strijd met de openbare orde." Tegelijk gaat het in een opleggende functie als "recht van openbare orde" dienst doen als synoniem voor dwingend toepasselijk eigen recht. In plaats van

2 Hifdst 5 , par. 2. 
het ongewenste wremde recht wordt eigen recht toegepast als zijnde "van openbare orde". Deze gang var zaken in het ipr illustreert de centrale positie van het openbare orde begrip als juridisch handvat om ongewenste resultaten af te weren en gewenste resultaten af te dwingen.

Kranenburg (1895) betoogt dat "het beginsel van de openbare orde" in alle rechtsgebieden dezelfde afwerende en opleggende werking en ook dezelfde rechtens niet te passeren kerninhoud heeft. Deze kerninhoud oriënteert zich volgens hem aan persoonlijke vrijheid van de mens als misschien het meest tekenende kenmerk van de Nederlandse samenleving. Gezien in een doorgaande ontwikkelingsijn sluit mijn opvatting van vrijheid als leidend beginsel van mensenrecht in de kern van het openbare orde begrip daar mooi bij aan. Ook het beginsel zorg is bij Kranenburg in de kern wan het openbare orde begrip te winden, in de vorm van bescherming van maatschappelijk zwakkere groepen. Het beginsel trouw is bij hem vertaald in wetszekerheid. Dat past in een in die tijd gangbare opvatting van het legaliteitsbeginsel: geen recht buiten de wet.

De ontwikkelingen in het ipr in de laatste honderd jaar laten langs twee juridische wegen een toenemende invloed wan mensenrecht zien. De ene weg loopt via de opkomst van voorrangsregels ${ }^{4}$ en een steeds verdergaande inhoudelijke harmonisering van recht via internationale verdragen. ${ }^{5}$ De andere weg loopt via het transformeren van morele beginselen in algemene rechtsbeginselen ${ }^{6}$ en in universele beginselen van mensenrecht. ${ }^{7}$ Het begrip openbare orde doet wooral dienst als een verbindingsweg in noodsituaties. Polak typeert deze functie in de rechtspraak van de Hoge Raad sedert 1963 als "ultimum remedium" voor het tot uitdrukking brengen van universele morele beginselen van recht.

Als "ultimum remedium" in de richting van wereldrecht blijkt het begrip openbare orde een test voor het tot uitdrukking brengen wan op het EVRM gebaseerde beginselen van mensenrecht in het ipr goed te doorstaan. ${ }^{8}$ Met name in de discussie over een lerse echtscheidingskwestie is het toespitsen van deze test op drie beginselen van mensenrecht naar ik meen overtuigend. De afwerende en opleggende deelfuncties van het openbare orde begrip in het ipr kunnen hier adequaat gebundeld worden in een bemiddelende functie in dienst van mensenrecht.

Evenals in het ipr zijn ook in het contractenrecht een groevende doorwerking van mensenrecht en de werking van het begrip openbare orde duidelijk met elkaar in verband te brengen. Bij de bespreking van hei contractenrecht is langs diverse wegen a annemelijk geworden dat de beginselen vrijheid, trouw en zorg inderdaad alle relevante nomatieve en feitelijke aspecten kunnen bestrijken om tot een ewenwicht tussen individueel en algemeen belang te komen dat past in het Nederlandse recht." De reêle en ideële aspecten in Nietwenhuis' drie beginselen wan contractenrecht sporten met drie beginselen van mensenrecht. 
Ook een benadering wan het contract als een zich in fasen in de tijd ontwikkatende rechtsbetrekking leidt to hetzelfde resultaat.

Duidelijker dan in het ipr is in het contractenrecht een samenloop van deelunctes van het openbare orde begrip naar voren gekomen. In het contractenrecht is beter zichtbadr dat een overkoepelende bemiddelingsfunctie zich toespitst op een evenwicht tussen private en publieke antonomie. De afwerende deelfunctie die werkt als beperking van de contractsvrijheid geef de grens aan van private autonomie. Gelijktijdig werkt dat affweren wanuit een publiek gezichtspunt als bescherming van vitale materiele en geestelijke gemeenschapswarden. Vanuit dat gezichtspunt gaat het om uitoefening van publieke autonomie. Daaronder valt dan óbk het vaststellen van de grenzen van de contractswijheid als uitoefening van private autonomie.

De samenloop van afweren aan de ene kant en opleggen aan de andere kant is ook te zien in het werengingsrecht van politieke partijen. "Wat de inhoudelijke kant in dit rechtsgebied betreft kunnen enkele opmerkingen van Van den Bergh (1936) in deze studie als representatief worden beschouwd. Een daarvan gat over eerbied voor de persoontijkheid wan ieder mens, die als morele kem van het beginsel vrijheid in het openbare orde begrip tot uitdrukking dient te komen. Een andere opmerking gaat over een normatief criterium van democratie: dat de democratie har mogelijkheid van zelfcorrectie niet ontmomen mag worden. In dat criterium, het behoud van de democratische mogelijkheid tot zelfcorrectie binnen een rechtsorde, komen de beginselen vrijheid, trouw en zorg op een gelukte manier tot uitdrukking.

In vergelijking met het contractenrecht en het verenigingsrecht lijkt in het bestuurstecht een leidende positie van een mensenrechtelijk georiënteerd vrijheidsbeginsel wer te zoeken." In dit rechtsgebied wordt vooral de aanbodkant van de zorg belicht. De achterliggende wrijheid wan de burger blijft in de schaduw. Algemene beginselen wan behoorlijk bestuur zijn primair gericht op betrouwbaar en zorgvuldig overheidsbestuur conform de resultaten wan democratische besluitvorming.

In "een ander jasje" werken algemene beginselen wan behoorlik bestum ook door in het politierech." Bij het politiebegrip openbare orde dratit het feitelijk om de zorg van de pollitic voor en ordelijk verloop wan het gemeenschapsleven op strat en ander openbar. terrein. Het handhaven van de openbare orde door de politic betret volgens Van der Meulen rechtstreeks het fundamentele recht op bewegingsvrijheid van betrokkenen in de openbare rumte. Zijn opvating dat ordehandhaving zowel bescherming als beperking van deze fundamentele waijheid implicent kan $\mathrm{k}$ delen. Zijn opvatting dat interventies in andere kernaspecten van vrijheid (onaantastbaarheid en uitingswijheid) niet inherent zjin aan ordehandhaving deel ik niet. Daarbij ga ik uit van een rechtsbeschermende in platis van een instrumentele opvatting van ordehandhaving. Als fundamentele bewegingsvijheid 
in de openbare ruimte in nomatieve zin als richtinggevend voor ordehandhaving wordt erkend, dan zijn ook de andere genoemde kernaspecten van wrijheid niet uit het politiebegrip openbare orde weg te denken.

Een tendens van een meer instrumentele dan rechisbeschermende toepassing van rechtsbeginselen is ook in het kader wan het strafprocesrecht ter sprake gekomen. ${ }^{13}$ Naast beginselen die expliciet met openheid van gesprek en openbaarheid van de procesgang te maken hebben gait het daarbij evenals in het politierecht ook om private wrijheid. Het pleidooi van Bal voor een oriëntering aan mensenrechten in het strafrecht en mijn dốortrekken van dit pleidooi naar drie beginselen van mensenrecht is ook te vertalen naar andere rechtsgebieden. Met name ook naar het politierecht. Daar kan een mensenrechtelijk georiënteerde opvatting wan vrijheid in al haar kernaspecten tegenwicht leveren tegen een instrumentele opvatting van bewegingsvrijheid bij het handhaven van de openbare orde.

In het strafrecht gaat het in de bonte verzameling misdrijven en overtredingen betreffende de openbare orde en de zeden vooral orm zorg voor zwakkeren en het tegengaan van discriminatie. In verband daarmee is een bemiddelende rol van het beginsel trouw tussen vrijheid en zorg komen bowen drijven. In een doorlopend proces van rechtsvorming en rechtstoepassing gaat het erom dat op een integere manier wordt ingestaan voor het beschermen van kwetsbare individuele vrijheid. ${ }^{4}$ Op het individuele niveau wordt deze bemiddelende rol van het beginsel trouw bevestigd in de kwestie waarin het tegengaan van rassendiscriminatie staat tegenover de integriteit van de journalist die "te goeder trouw" een bijdrage levert aan het publieke debat in de media..

De doctrine van ondeelbaarheid en onderlinge afhankelijkheid van alle rechten van de mens sluit aan bij de idee van interne samenhang van drie beginselen. van mensenrecht. ${ }^{16}$ Evenals het hele onderzoek in het Nederlandse recht bevestigt ook deze doctrine nog cens mijn stelling over de notie mensenrecht als morele kern van reclat naar Westerse traditie. Bij het praktisch aannemen van de ondeelbaarheid en onderlinge afhankelijkheid van een mensenrechtelijk georiënteerde inhoud van het openbare orde begrip kan een bundeling van deelfuncties van dat begrip moeilijk uitblijven. Het onderzoek in de verschillende deelgebieden van het Nederlandse recht heeft niet alleen bevestigd dat het openbare orde begrij als kwalificatie van dwingend recht algemeen inzetbaar is. Het heef ook aangetoond dat met het oog op de notie mensentecht de afwerende en opleggende, beperkende en beschermende deelfuncties van het begrip openbare orde soms nauwelijks uit elkaar te houden zijn. In zulke verwarrende situaties kan de idee van bemiddeling onder de noemer openbare orde verhelderend werken. Het dubbelzinnig karakter wan het begrip openbare orde, als dwingend recht en als bemiddeling met het oog op mensentechtelijk georiënteerde vrijheid tekent de inherente spanning tussen openbare orde en mensenrecht. 


\section{Houdbaarheidstest in Nederlands recht geslaagd}

De voorgenomen houdbaarheidstest in het Nederlandse recht beschouw ik als geslaagd. Daarmee beweer ik niet dat nu ieder of zelfs maar iemand meteen moeiteloos met dit hulpmiddel overweg kan. Het gaat atls eerder gezegd on de potentielle praktische bruikbaarheid. Ten aanzien van drie beginselen van mensenrecht is die naar ik meen aannemelijk geworden. Rest een bespreking van het moreel gezichtspunt van alpartijdigheid.

In het gekozen gespreksmodel van recht is het perspectief van alpartijdigheid gekoppeld aan de openheid van het op onderlinge verstandhouding gericht gesprek. ${ }^{17}$ Het gaat erom dat alle relevante aspecten en belangen op een authentieke manier ingebracht kunnen worden en serieus bij de besluitvorming betrokken worden. Houvast bieden de noodzakelijke vooronderstellingen van toegankelijkheid, kritiseerbaarheid en oprechtheid van het open gesprek. Die vooronderstellingen bieden ook houvast voor de legitimiteit van wetgeving en rechtspraak. ${ }^{18}$ De legitimiteit wan overheidsbestum is aflankelijk van het gekoppeld houden van bestuurlijke macht an het democratisch besluitvormingsproces.

Uit het onderzoek in het Nederlandse recht is gebleken dat ook bij de uitvoerende bestuurstaak zélf de vrijheid van de burger meer op de voorgrond lijkt te komen. Dat is op te maken uit de wetsgeschiedenis van de Algemene wet bestuurstecht. Naast actieve zorgplicht van het bestuur worden ook subjectiviteit van de burger en wederkerigheid van de relatie bestuur-burger als kaderprincipes van deze wet aangegeven. De principiële vrijheid van de burger om naar eigen inzicht voor eigen belangen op te komen en de rechtsplicht van de overheid om deze vrijheid te respecteren worden onderkend. In plaats van voomverp van overheidszorg via het bestuursrecht wordt de burger deethemer in het bestuursrecht. Met het oog op het noreel gezichtspunt van alpartijdigheid gaat dat in de goede richting.

Als een tendens in de richting van alpartijdigheid kan in het ipr de opmars van partijautonomie bekeken worden. In het contractenrecht daarentegen hebben we vrij uitgebreide beperkingen van partij-autonomie kunnen constateren. Toch kunnen ook die uitgelegd worden als tendens in de richting van alpartijdigheid. De beperkingen zijn bedoeld om voor zwakkere contractpartijen to meer evenwicht in machtsverhoudingen te komen. In een wederkerige, aan elkaar gewaagde autonomie van betrokken partijen is meer kans dat alle relevante belangen tot hun recht komen dan bij het sterk domineren van én van de contracterende partijen ten koste van de ander. In het verenigingsrecht van politieke partijen is het criterium van behoud van de democratische mogelijkheid tot zelfcorrectie naar voren gekomen als illustratief voor de openheid van een alpartijdige besluitvorming.

De eerder besproken doctrine van ondeelbaarheid en onderlinge afhankelijkheid van alle rechten van de mens verdient ook hier nog eens de andacht. Deze doctrine loopt niet alleen parallel met de ondeelbaarheid en onderlinge afhankelijkheid van drie beginselen van mensenrecht. In een moreel gezichtspunt van alpartijdigheid heeft ze ook direct to 


\section{Hoofdstuk?}

maken met het achterblijven van zorg. In verhouding tot Klassieke vrijheidsrechten blijven sociale mensenrechten achter. De ontwikkeling van de gewetensvrijheid als eerste klassiek vrijheidsrecht heef de achtergrond daarvan laten zien. ${ }^{19}$ Vermeulens "oeverloosheidsthe-

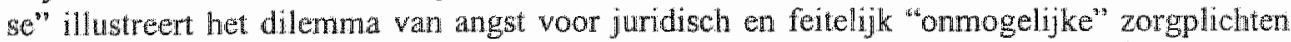
wan overheden bij het principieel erkennen van externe gewetenswrijheid. ${ }^{20}$ Dit soort dilemma's speelt ook een belangrijke rol bij het erkennen van sociale mensenrechten. Bij die erkenning is in de context van het Europees Gemeenschapsrecht in de discussie met Steyger nog een ander aspect van angst naar voren gekomen: sociale rechten leiden tot verplichte zorg van overheden. Die verplichte zorg doet te kort aan particuliere vrijheid. Sons profiteren er mensen van die de grootste mond hebben en komt de zorg niet ten goede aan mensen die deze zorg het meest nodig hebben. ${ }^{21}$

Tegenover deze angsten heb ik aan de hand van de leer van positieve verplichtingen uit het EVRM het zinvolle wan een praktische erkenning van ondeelbaarheid en onderlinge aflankelijkheid van alle mensenrechten aannemelijk proberen te maken. Dat geldt zowel voor rechten die primair met vrijheid als voor rechten die primair met zorg te maken hebben. ${ }^{22}$ Ik heb in dit verband voorgesteld alle statsverplichtingen op het gebied van klassieke én sociale mensenrechten op te vatten als positieve verplichtingen.

In mijn voorstel beginnen alle staatsverplichtingen in ieder geval met de positieve verplichting om een morele kern van individuele vrijheid te respecteren. Daaruit volgen voor zover dat met het oog op respect voor die kernvrijheid nodig is verdere verplichtingen. Die kunnen bestaan in de verplichting om actief te beschermen en verder in de verplichting om te verwezenlijken. In de vereiste positieve grondhouding van respect komt telkens een kern van morele vrijheid als praktisch operationeel richtsnoer voor het rechtsgehaite van rechtsbeslissingen naar voren. In het verlengde daarvan ligt betrouwbare, actieve zorg voor het beschermen of feitelijk verwezenlijken van het betreffende mensenrecht. Daarbij is het niet zo dat zorg in dienst komt te staan van vrijheid ${ }^{23}$ Vrijheid en zorg zijn intern met eikaar verbonden en aan elkaar gewaagd. De omvang van feitelijke zorg wordt telkens bepaald door het recht doen an de kern van vrijheid waar het in het gegeven geval om gaat.

Dat bij het scheiden van vrijheidsrechten en sociale mensenrechten relevante belangen gemakkelijk buiten beeld kunnen blijven mag duidelijk zijn. Datzelfde geldt voor opvattingen watrin groepen vrijheidsrechten als gescheiden behandeld worden. Een mooi voorbeeld darvan is Vermeulens loskoppeling van interne gewetensvrijheid als juridisch vrijheidsrecht en een algemeen recht op exteme gewetensvrijheid als juridisch onmogelijk. Mijn commentaar op zijn "oeverloosheidsthese" kan ook gelezen worden als cen pleidooi voor alpartijdigheid in het open democratisch gesprek. In dat gesprek mag gewetensvrijheid niet gereduceerd worden tot een min of meer vrijblijvende morele inspiratiebron, 
zoals Vermeulen voorstaat. Dat doet denken aan de tijd waarin basale zedelijke beginselen wan behoorlijk handelen nog niet getransformeerd waren in rechrbeginselen. ${ }^{24}$

Het behandelen van gewetensvrijheid als morele inspiratiebron in plaats van als universeel moreell recht doet ók denken aan de besproken twee ogenschijnlijk tegengestelde richtingen waarin Romeinse denkers zich na het verval van de Griekse polis van de polisfilosofie afkeerden. ${ }^{25}$ Aan de ene kant ging het denken in de richting van een kosmopolitisch universalisme. Aan de andere kant richtte het zich sterk op innerlijke autonomie. Zijn we nog steeds bezig met pogingen on deze beide denkrichtingen met elkaar te verzoenen? De doctrine van ondeelbaarheid en onderlinge afhankelijkheid van alle mensenrechten en mijn voorstel van drie beginselen van mensenrecht in een alpartijdig perspectief als richtsnoer voor ieder lijken daar underdaad voorbeelden van.

\section{Een proef met de kwestie Geertruidenberg: is dit recht?}

De feiten zijn bekend. ${ }^{26}$ Voor het gemak herhaal ik hier het begin en de afloop van de rechtszaak. Een kapelaan van de rooms katholieke St. Gertrudisparochie te Geertruidenberg houdt op 23 juni 1957 aldaar een openbare godsdienstoefening in de vorm van een door hem georganiseerde processie. Een strafrechtelijke vervolging tegen de kapelaan is het gevolg. Volgens de tenlastelegging heeft hij "de R.K. openbare godsdienst uitgeoefend op een andere plaats of op andere plaatsen, dan waar de openbare godsdienstoefening, naar art. 184 lid 2 (art.107 lid 2 oud) der Grondwet volgens de bij de mitvaardiging der Grondwet van 1848 bestaande wetten en reglementen was toegelaten." De kapelaan roept artikel 9 van het voor Nederland in 1954 in werking getreden Europees verdrag tot bescherming van de rechten van de mens en de fundamentele vrijheden (EVRM) in, dat dateert van 4 november 1950. Volgens de tekst wan artikel 9 lid 2 EVRM is een beperking van de in het eerste lid neergelegde godsdienstvrijheid slechts toegelaten als die niet alleen bij wet is woorzien in een democratische gemeenschap, maar ook "noodzakelijk" is voor de bescherming van de openbare orde.

In het tweede Geertruidenberg-arrest draait de Hoge Raad, in vijfde rechterlijke instantie in dit proces, het door het Hof Arnhem uitgesproken ontslag van rechtsvervolging terug. De Hoge Raad oordeelt dat de rechter alleen dan een wettelijke beperking van de vrijheid van godsdienst als niet noodzakeljk voor de bescherming van de openbare orde mag beschouwen "indien het ten enen male ondenkbaar zou moeten worden geacht dat een wetgever, gesteld woor de noodzaak met het oog op de bescheming van de openbare orde te dien aanzien een regeling te treffen, daartoe een zodanige regeling in redelijkheid zou kunnern treffen of handhaven." 


\section{Hoofdstuk 9}

Artikel 9 EVRM betreffende de vrijheid van gedachten, geweten en godsdienst is vrij uitgebreid besproken in verband met de gewetenswrijheid. ${ }^{27}$ Hier gaat het om het peilen van het rechtsgehalte van de uitspraak van de Hoge Raad aan de hand van het richtsnoer voor ieder. Op de eerste trap van toetsing is de in ieder geval te respecteren vrijheidskem duidelijk: wrijheid van godsdienst. Daarmee is ook de strekking van bet belang van de verdachte gegeven: het als katholiek ambtsdrager in vrijheid organiseren en in het openbaar houden van een processie in de parochie waar hij werkzaam is, de St. Gertrudisparochie in het Noord-Brabantse Geertruidenberg. Actieve zorg van de overheid in de varianten beschermen of verwezenlijken is daarvoor niet nodig.

Op de tweede trap wan toetsing rijst de vraag of er doelstellingen of andere factoren zijn die een beperking van de reikwijdte van het betreffende wrijheidsrecht rechtvaardigen. Het Hof Arnhem vindt wan niet en oordeelt dat de in het tweede lid van artikel 184 Grondwet neergelegde beperking van de godsdienstvrijheid niet geacht kan worden noodzakelijk te zijn voor de openbare orde. De Hoge Raad offert de godsdienstvrijheid van de kapelaan in het gegeven geval op aan het redden wan het oude grondwettelijke processieverbod. De Hoge Raad doet dat met de hierboven nog eens geciteerde abstracte openbare ordeformule.

Kan de uitspraak van de Hoge Raad gerechtwaardigde overheidszorg genoemd worden? Nee. In een alpartijdige opvatting van private en publieke altonomie is de openbare ordeformule die de Hoge Raad in dit geval uitspreekt voldoende om tot deze conclusie te komen. De Hoge Raad distantieert zich met deze formule van een positieve grondhouding wan respect en bescherming voor de in geding zijnde godsdienstvrijheid als private autonomie. Bovendien distantieert de Hoge Raad zich van een concrete toetsing aan het EVRM, als in ieder geval veel recentere uitdrukking van publieke autonomie dan het oude grondwettelijk processieverbod. De Hoge Raad geeft in dit geval niet de rechtsbescherming die het toepasselijke artikel 9 EVRM de werdachte had kumen bieden. Trouw van de Hoge Raad aan de Grondwet kan hier niet uitgelegd worden in de zin van het mensenrechtelijk beginsel trouw. Dat vraagt in dit geval een praktische bemiddeling tussen individuele vrijheid van de kajpelaan, algemene aspecten van vrijheid (met name ook met het oog op nietkatholieken in Geertruidenberg) en overheidszorg voor de continuitteit van het rechtsstelsel als geheel. In plaats daarwan houdt de Hoge Raad zich compleet afrijdig van een concrete afweging van relevante belangen. Conclusie: de rechtsordening in dit geval is niet te kwalificeren als mensenrechtelijk georiènteerde rechtsordening.

\section{Drie beginselen van mensenrecht als universeel richtsnoer voor ieder in een wereldorde in wording?}

In zijn beschouwing van vijfentwintig jaar rechtspraak wan de Hoge Raad op het gebied van het ipr, sedert de wijziging van de cassatiegrond schending van de wet in schending van het recht in 1963, signaleert Polak als rode draad een ontwikkelingslijn in de richting 
van "wereldrecht." ${ }^{\text {28 }}$ Zo"n ontwikkelingslijn walt ook in de andere onderzochte rechtsgebieden in het Nederlandse recht te onderkennen. Denk maar aan internationale ontwikkelingen in het contractenrecht en aan de aanscherping van strafbepalingen op basis van het $\mathrm{VN}$-werdrag tegen rassendiscriminatie.

Een ontwikkeling in de richting van wereldrecht is niet specifiek Nederlands. Ze wordt gestunrd door bovennationale, regionale en mondiale problemen. Evenals bij de opkomst van het ipr wordt deze ontwikkeling mede geïnspireerd door economische expansie, die nu duidelijk de vormen van wereldhandel heeft aangenomen. Op het gebied van rechten van de mens wordt de ontwikkeling in de richting wan wereldrecht mede geïnspireerd door een wisselwerking van regionaal georiënteerde verdragen zoals het mensenrechtelijk EVRM en het economisch gericht EG-verdrag en wereldwijd georiënteerde VN-verdragen, zoals het IVBPR en het IVESCR.

Al deze ontwikkelingen wijzen in de richting van groei naar een wereldorde, met de VN als overkoepelende politieke organisatie. Dat binnen de VN aan de onderhandelingstafel vaak grote verdeeldheid bestaat op rechtspolitiek gebied en dat $\mathrm{VN}$-vredesmachten vaak praktisch machteloos staan op oorlogsterrein valt niet te ontkennen. Maar dat de $\mathrm{VN}$ als wereldorganisatie bestaat en werkzaam is, valt ook niet te ontkennen. Hoe gebrekkig de feitelijke werkzamheid soms ook is, er is geen vreedzaam alternatief voor het gesprek voor het forum van de VN in deze meest gewelddadige eeuw die de mensenwereld ooit gekend heeft.

Acties van (wereld)burgerlijke openbaarheid kunnen een belangrijke rol spelen bij wereldwijd georiënteerde rechtsontwikkeling. Voorbeelden daarvan zijn niet ver te zoeken. In alle kranten en andere media liggen ze voor het oprapen. Als ik dit schrijf (jull 1995) is een spectaculaire actie van Greenpeace op milieugebied het meest recente voorbeeld van het met succes op korte termijn mobiliseren van de publieke opinie. "Brent Spar wordt eventjes brandpunt van de wereld" kopte mijn lokale krant. ${ }^{29}$ Als latste verweer tegen het dumpen van het Shell-olieopslagplatform Brent Spar in de Atlantische Oceaan wisten twee actievoerders wan Greenpeace zich voor het oog van de wereldpers bovenop het olieplatform te verschansen. "Onder druk van de publieke opinie en Westeuropese regeringen" verklaarde de Britse Shell-organisatie op 20 jumi 1995 van thet afzinken van het platform af te zien. Dat gebeurde wlak vóó het voorgenomen dumpen, tegen de opvatting van de Britse regering in. ${ }^{3 / 2}$ Ook al bleken Shell en de Brilse regering uiteindelijk, zoals ook Greenpeace later inzag, gelijk te hebben Deze affaire kan een belangrijke impuls zijn voor de hoognodige verdere uitwerking van internationale verdragen over de bescherming van het milieu in de Noordzee.

Ook een ander recent voorbeeld in de richting van wereldrecht haal ik uit de lokale krant: "Hulporganisatie wil vervolging van sekstoeristen." In hel rapport "Het kind van de

Hfdst. 5. par. 6 .

29 Limburgs Dagblad 20 juni 1995.

30 "Engeland haalt uit maar de "hysterie" frond Brent Spar" kopt het Limburgs Dagblad op 23 juni 1995.

31 Limburgs Dagblad 4 juli 1995. 


\section{Hoofdstuk 9}

rekening" geeft do kinderhulporganisatie Child Right Worldwide een inventarisatie van seksuele exploitatie van kinderen. De organisatie dringt aan op een wetswijziging. Die moet het mogelijk maken Nederlanders die in thet buitenland kinderen seksueel misbruiken in eigen land te vervolgen. Het gaat vooral orn zogenaamde sekstoeristen naar landen in Azié en Latijns-Amerika. Dit voorbeeld sluit direct aan bij de onderzochte oniwikkeling van een mensenrechtelijk georiënteerde aanscherping van strafbepalingen betreffende de operibare orde. ${ }^{32}$

Als laatste voorbeeld een onverwacht pleidooi in de richting van wereldrecht: "Paus op de bres voor de vrouw." In een open brief komt paus Johamnes Paulus II met opzet vlak voor het begin van de VN-vrouwenconferentie in Peking op voor de rechten van de vrouw. De paus doet een oproep aan alle staten, de gelijkwaardigheid tussen man en vrouw te erkennen en de rechten van de vrouw te beschermen. Hij noemt onder andere gelijke kansen op de arbeidsmarkt en in het onderwijs, gelijk loon en een gelijkwardige positie binnen het gezin. Of het helpt is nog maar de vraag. Hoe dat zij, dit pleidooi slluit in ieder geval an bij de wereldwijde campagne die vanaf 1991 vanuit de vrouwenbeweging gevoerd wordt voor integratie van mensenrechten van vrouwen. ${ }^{34}$

De bewering dat een ontwikkeling in de richting van een wereldrecht in een wereldorde de praktische bruikbaarheid van het door mij voorgestelde richtsnoer in de kaart speelt lijkt niet te gewaagd. Zo lang rechtsontwikkeling mensenwerk blijft, zal wereldrecht zich in normalieve zin blijven oriënteren aan mensenrecht. Een oriêntering op vrijheid, trouw en zorg is te beschouwen als elementair mensenrechtelijk, ondat ze de meest basale morele aspecten wan behoorlijk handelen in iedere rechtsorde omvat. Daardoor kan deze oriëntering dienst doen als een universeel richtsnoer voor ieder in een wereldorde in wording.

33 Limburgs Dagblad 11 juli 1995.

34 V. J. Swicbel De WN-Wereldconferentie Mensenrechen, Actualiteitenkatem Nemesis 1993, nr. 5, p. $30-31$ 


\section{Samenvatting}

In de eerste vier hoofdstukken, die tezamen het eerste deel van deze dissertatie uitmaken, wordt gepoogd een rechtsvindingstheorie te ontwikkelen op basis van Jirgen Habermas' theorie var de communicatieve rationaliteit, het zogenaamde "gespreksmodel". In de daar" op volgende vier hoofdstukken, het tweede deel, wordt de vruchtbaarheid van deze theorie onderzocht via een analyse van de betekenis van het begrip "openbare orde" in het Nederlandse recht.

In het eerste hoofdstuk wordt het probleem van de verhouding van formele en materiele rechtvaardiging in het recht geïntroduceerd aan de hand van het tweede Geertruidenbergarrest (HR 19 januari 1962, NI 1962, 107). Het ging hier om een kapelaan die te Geertruidenberg een verboden processie had georganiseerd. Volgens hem was dit sinds 1848 op de grondwet gebaseerde verbod dat inhield dat processies verboden waren waar ze niet al ruim voor 1848 zonder onderbreking gebruikelijk waren, in strijd met do godsdienstvrijheid zoals gewaarborgd door art. 9 EVRM. Het Hof had de kapelaan in het gelijk gesteld, omdat het van mening was dat er in het concrete geval geen sprake was wan een noodzaak van bescherming van een belang van openbare orde. De Hoge Raad was het echter oneens met het Hof. Volgens de HR was alleen van belang of de regeling als zodanig naar redelijkheid in het belang van de openbare orde geacht kon worden. De Hoge Raad achtte derhalve een toetsing in concreto niet nodig en hanteerde een historisch-wetspositivistische interpretatie, waarin geen aandacht werd geschonken aan de sinds 1848 radicaal veranderde positie van de katholieken in Nederland. De vraag die naar aanleiding van deze uitspraak wordt opgeworpen is hoe de onrechtvaardigheid van deze uitspraak juridisch kan worden onderbouwd. Daartoe wordt een zoektocht begonnen naar de imnerlijke relatie tussen recht, openbare orde, mensenrechten en democratie.

Voornitlopend op dat onderzoek worden in het eerste hoofdstuk twee stellingen geponeerd. De eerste stelling luidt dat het begrip "openbare orde" algemeen inzetbatr is. In tegenstel ling tot wat door thet weede Geertruidenberg-arrest wordt gesuggereerd, is het bogrip alleen goed te verstaan in samenhang met de diepste waarden die aan ons recht ten grondslag liggen. De tweede stelling luidt dat "mensenrecht", gezien als de aan de diverse mensenrechten, de rechtsstaat en de democratie ten grondslag liggende idee, de morele kern van ons recht uitmaakt. In die context geplaatst zal ook blijken dat openbare orde niet alleen een tegen daarop inbreuk makende burgers beschermd overheidsbelang vertegenwoordigt, maar dat er ook een betekenis aan toekomt in de relaties tussen burgers onderling en dat het zelfs om een de burgers tegen de overheid beschermend belang kan gaan.

Het feit dat rechten van de mens in juridische vomnen steeds meer in het begrip openhare orde tot uitdrukking komen, is op het eerste oog een positieve ontwikkeling. Het "machtige" begrip openbare orde komt steeds meer expliciet in dienst te staan van rechten van de mens. Het gevaar dreigt echter dat de notie mensenrecht onllherkenbaar wordt, steeds meer "ingelijfd" wordt in de ordenende macht van "openbare orde". 
Om de herkenbaarheid en werkbaarheid van de notie mensenrecht te bevorderen wordt in deze studie geprobeerd ze te concretiseren in een richtsnoer dat bestaat uit drue beginselen: vrijheid, trouw en zorg.

Het tweede hoofdstuk begint met de vraag of in een radicale opvatting sprake kan zijn van een onvervangbare inhoudelijke kern van recht. Moet in een radicaal opgevatte democratie niet iedere inhoud vari recht, inclusief de mensenrechten, als veranderlijk van inhoud door de burgers ter discussie kunnen worden gesteld? Als dat zo is, zijn recht en redelijkheid identiek met de uitkomst van een democratisch debat. Een in deze richting tenderende theorie van de rechtsvinding en van de verhouding van rechter en wet, is in 1992 verdedigd door Barendrecht in zijn dissertatie "Recht als model van rechtvaardigheid". Daarin bekritiseert hij de steeds sterker wordende tendens naar "Einzelfallgerechtigkeit" door toepassing van vage begrippen. Volgens Barendrecht dient rechtspraak programmatisch te opereren op een wijze die vergelijkbaar is met hoe wetenschap volgens Popper en Lakatos opereert. De rechter wordt daarmee tot een quasi-onderzoeker en een quasiwetgever. Barendrecht kent geen betekenis toe aan rechtsfilosofische opvattingen over gerechtigheid en hij placht de wetgever, waarvan hij het staatsrechtelijk primaat niet ontkent, in een overwegend passieve, volgzame relatie te plaatsen ten opzichte van de rechter te plaatsen.

Mijn kritiek op Barendrecht betreft niet zijn bezwaren tegen een vorm van rechtsvinding waarbij geen lijn meer te ontdekken valt in de rechtspraak. Dit kan echter gezien worden als het resultaat van een verkeerd gebruik van vage normen, die juist niet los van rechtsfilosofisch inzicht in hun betekenis dienen te worden gehanteerd. Interessant is dat Barendrecht aan het einde van zijn boek ook verwijst naar Habermas' gespreksmodel, dat mogelijk inhoud kan geven aan rechtvaardigheid. Daarbij verwaarloost hij echter dat Habermas gerechtigheid in het indiwiduele geval niet uitsluit als resultaat van een dialogisch proces. Het feit dat Barendrecht kiest voor een leeg rechtvaardigheidsbegrip maakt duidelijk dat hij niet uitgaat van een interne samenhang tussen democratie en een bepaalde inhoud van de rechtsidee. Dit onderzoek gaat daar wel vanuit. Het veronderstelt een zodanige interne samenhang tussen de notie mensenrecht en democratie, dat de vraag naar het primaat van een van beide in principe irrelevant is.

De houdbaarheid van deze vooronderstelling wordt onderzocht aan de hand van het begrip openbaarheid, dat in een gespreksmodel van recht correspondeert met openheid van publieke discussie. De openheid van gesprek houdt al op het empirisch niveau van het alledaagse gesprek een principiële erkenning in van menselijke vrijheid en waardigheid. Deze erkenning ligt besloten in de vooronderstellingen waarvan ieder altijd al moet uitgaan om een concreet op onderlinge verstandhouding gericht gesprek te kunnen voeren. Deze vooronderstellingen zijn: afwezigheid van dwang, toegankelijkheid voor kritiek en oprechtheid.

De principiele erkenning van menselijke vrijheid en wardigheid is de morele kern van de notie mensenrecht en tegelijk de kern van een op het open gesprek gebaseerde opvatting van democratie. Dat is de grondgedachte van dit onderzoek. Die gedachte maakt de vraag natr het primaat van mensenrecht of democratie in principe irrelevant. 
Uitgaande van deze gedachte wordt de interne samenhang tussen mensenrecht en democratie geanalyseerd tegen de achtergrond van de ontwikkeling van de modeme politieke filosofie (Hobbes, Locke, Rousseau en Kant), waarop Habermas heeft voortgebouwd. Bij hem komt de al in het werk van Rousseau en Kant vermoede interne samenhang tussen mensenrecht en democratie tot uitdrukking in het normatief gehalte van de witoefening van publieke autonomie.

In het derde hoofdstuk wordt beschreven hoe Habermas uit de idee van gelijkoorspronkelijke private en publieke autonomie stap voor stap een systeem van subjectieve rechten heeft gereconstrueerd. Achtereenvolgens: private handelingswrijheid, associatie-vrijheden, rechtsbescherming, politieke rechten en tenslotte sociale rechten (waaronder ook ecologische). Deze rechten zijn voorwaarden die het mogelijk maken het samenleven door recht legitiem te regelen. Het gaat dus om een reconstructie van voorwaarden voor legitien recht. Het zijn deze voorwaarden die het micro-sociale principe van open communicatie tussen gesprekspartners (de zogenaamde "leefwereld"), reproduceren op het systeemniveau van een democratische samenleving. In dit verband wordt de samenhang besproken van private en publieke autonomie met de realiteit van politieke macht. Geconcludeerd wordt dat het recht voor zijn legitimiteit en daarmee voor zijn sociaal-integratieve kracht uiteindelijk aangewezen blijft op de uitoefening van publieke autonomie door de rechtsgenoten. Omdat deze uitoefening staat of valt met openbaarheid wordt aansluitend het openbaarheidsbegrip nader besproken. Dit leidt tot een illustratie van de innerlijke kwetsbaarheid van een consequent op vrijheid georiënteerde democratische rechtsordening.

En hoe staat het met openbaarheid en gesprek in de rechtszaal? Uitgaande van de idee dat open communicatie in rechte mogelijk is, wordt geanalyseerd wat dit van de rechter vergt. In de eerste plaats zou het betekenen dat hoewel de partijen zich veelal instrumenteel en strategisch zullen opstellen, de rechter zich niet alleen communicatief ten opzichte van hen dient to gedragen, maar hen tot een overeenkomstige houding moet pogen te brengen. Het umpliceert ook dat waar wet en gerechtigheidsoordeel niet met elkaar in overeenstemming zijn te brengen, de rechter daarvan geen geheim moet maken. Verder zal de rechter moeten pogen om het gerechtigheidsgevoel van partijen, dat veelal georiënteerd is op de leefwereld, te relateren aan de gerechtigheidsidee op systeemniveau. Hij vormt als het ware ten brug tussen beide. Maar dit veronderstelt uiteraard dat de kloof inderdaad te overbruggen is. Qua heuristische methode impliceert dit dat de rechter in staat moet zijn om een concreet vraagstuk zowel vanuit het perspectief van ieder van de partijen als dat van het rechtssysteem waar te nemen. Dit wordt in navolging van Van der Burg (1991) "alpartijdigheid" genoemd. Een rechter moet derhalve goed kunnen communiceren, een goed ontwikkeld rechtsgevoel hebben en pro en contra evenwichtig kunnen afwegen. Genoende rechterlijke deugden corresponderen duidelijk met zin voor waarheid, rechtvaardigheid en oprechtheid, de drie essentialia van Habermas communicatieve rationaliteit. Maar het is nog niet duidelijk hoe deze rechterlijke openheid vertaald kan worden in cen concept van juridische alpartijdigheid.

Het vierde hoofdstuk begint met de vaststelling dat Habermas de vraag naar juridische alpartijdigheid niet beantwoord heeft vanuit het gespreksmodel. 
Hij heeft zijn stelling betreffende de gelijkoorspronkelijkheid van private en publieke autonomie alleen uitgewerkt met het oog op een democratietheorie, dat wil zeggen een theorie van politicke alpartijdigheid, niet als rechtsvindingstheorie. Voor een rechtswindingstheorie is het niet voldoende te laten zien dat private en publieke autonomie elkaar veronderstellen. Vanuit het perspectief van het individu is private autonomie niet noodzakelijkerwijs gericht op participatie aan het politieke debat. Integendeel het is primair een recht om het eigen leven te leiden zoals het een ieder goeddunkt. Heeft private autonomie niettemin ook nog een innerlijke relatie tot publieke autonomie, de juridisch-maatschappelijke positie van de mens?

Om die vraag te beantwoorden wordt eerst nagegaan of andere theorieên van politieke alpartijdigheid dan die van Habermas wellicht ook suggesties bevatten voor een theorie van alpartijdige rechtsvinding. In het bijzonder de theorie van Van der Burg, aan wie het begrip "alpartijdigheid" ontleend is, komt daarvoor in aanmerking. Met Habermas argumenterend tegen een abstracte opvatting van onpartijdigheid zoals men die bijvoorbeeld bij Rawls aantreft, heeft Van der Burg de volgende eisen aan politieke alpartijdigheid verbonden: participatie van alle betrokkenen, het aangeven van de gronden en de zin wan beslissingen, reflectie op de uitvoerbaarheid ervan en afweging van de gevolgen van de beslissing voor de verschillende erbij betrokken groepen mensen. Van der Burg ziet dif als invuling van Dworkins idee van "equal concern and respect" als fundamentele norm van een democratische samenleving. Hoewel dit beginsel zich ook leent voor onmiddellijke toepassing op rechterlijke alpartijdigheid, waarvoor Dworkin het dan ook in cerste instantie heeft ontwikkeld, raakt daarbij Habermas' ideaal van de vrijwillige acceptatie van de beslissing uit het vizier.

Als twee bruggen tussen private en publieke autonomie en daarmee naar een begrip van juridische alpartijdigheid dienen opmerkingen van Van Roernund en Holtmaat. Van Roermund meent dat met Habermas' karakterisering van het democratisch discours als een "debat tussen vreemden", die "afzien van geweld" en elkaar daarbij ook het recht toekennen "vreemden voor elkaar te blijven", in feite net als bij Luhmann aan recht een niet in termen van communicatieve rationaliteit te begrijpen functioneel karakter wordt toegekend. Ons inziens geeft Habermas aldus echter juist de mogelijkheid aan de systeemwereld discursief to relateren an de leefwereld. Holtmaats kritiek betreft simplistische dichotomieën in het recht, zoals die tussen recht en behoefte. Een en hetzelfde recht kan echter meerdere functies tegelijkertijd hebben, functies die bowendien onderling gerelateerd kunnen zijn.

Vervolgens worden vrijheid, troww en zorg als drie beginselen van rechtens behoorlijk handelen afgeleid uit het open gesprek, gekoppeld aan de notie van alpartijdigheid. In het vrijheidsbegrip kont de aan het moderne westerse recht ten grondslag liggende idee van de subjectieve autonomie tot uitdrukking. De morele dimensie van de vrijheidsidee wordt als leidend beginsel van wan rechtens behoorlijk handelen geimpliceerd door de acceptatie van de ander als ander in het model van het open gesprek. Het begrip trouw als prijs van de vrijheid is de normatieve uitdrukking van de wederzijdse gebondenheid aan de criteria van theoretische en praktische rationaliteit. 
Het begrip zorg tenslotte is uitdrukking van het besef dat de openheid van het gesprek afhankelijk is van zekere sociale en materiële condities.

Aangetoond wordt dat de drie beginselen van rechtens behoorlijk handelen een wergelijking met Habermas' en Van der Burgs democratie-theorieën kunnen doorstaan. In het geval wan Van der Burg moet daar echter aan worden toegevoegd dat in Dworkin's criterium van "equal concerm and respect" het begrip trouw onvoldoende tot zijn recht komt. Het doet de positiviteit van het recht uit het vizier verdwijnen, een gebrek dat Dworkin dan weer moeizaam poogt te herstellen via zijn begrip van de "integrity" van het recht.

Een verdere vertaling van drie beginselen van rechtens behoorlijk handelen in drie beginselen van mensenrecht is te beschouwen als een moreel appèl bimnen het recht zelf. Dit appèl bestaat in het accentueren van de morele dimensie van vrijheid, trouw en zorg als universele moreel relevante aspecten van menselijk samenleven - in gevallen waarin rechtsbescherming in de knel dreigt te raken. Dat private en publieke autonomie door vrijheid, trouw en zorg innerlijk met elkaar verbonden zijn, impliceert geenszins dat deze drie elementen niet in een spanningsverhouding tot elkaar kunnen staan en in concreto tegen elkaar moeten worden afgewogen. Dit geldt in het bijzonder bij het begrip "openbare orde". Hoe de innerlijke samenhang tussen de drie beginselen van mensenrecht" nader is op te vatten is eén van de centrale thema"s van het tweede deel. De andere twee zijn de uitwerking van de stellingen van de algemene inzetbaarheid van het begrip "openbare orde" en van de idee van mensentecht als morele kern van ons recht.

Het tweede deel begint dan met het vijfde hoofdstuk, dat aan "openbare orde" in het internationaal privaatrecht is gewijd. Al in Kranenburgs dissertatie (1895) komen elementen van de drie beginselen van mensenrecht naar voren. Kranenburg betoogt dat "openbare orde" in alle gebieden van het recht dezelfde afwerende en opleggende functies vervuld met een zinkern die gerelateerd is aan het begrip valn de vrijheid van het individu. Zorg is volgens Kranenburg ook een deel daarvan, namelijk de bescherming wan de sociaal zwalkkere. Het beginsel trouw manifesteert zich bij Kranenburg als procedurele betrouwbaarheid of rechtszekerheid, die bij hem nog als trouw aan de wet wordt opgevat. Een steeds grotere distantie van het idee dat "openbare orde" een eigenschap van wetten is, latat zich aantonen via auteurs als Hijmans (1937) en Van Brakel (1953). Volgens laatstgenoemde heeft het begrip betrekking op de zedelijke grondslagen van de rechtsorde. Nog verder van een wetspositivistische opvatting van het begrip geraken we als ook het semipubliekrecht, dat eerder als per definitie van openbare orde beschouwd werd, na het Alnati-arrest (HR 13 mei 1966, N.J. 1967, 3, m.n. H.B.) door voorrangsregels beheerst gaat worden. Verheul (1973) bepleit dan tenstotte een volledig van het nationale recht geabstraheerd begrip van openbare orde dat georiënteerd is op de rechten van de mens, waarop volgens hem ook de zojuist genoemde voorrangsregels zijn gebaseerd. Volgens Polak (1990) heef deze opvatting inderdaad de overhand gekregen in de jurisprudentie.

Toenemende distantie van het nationale recht en oriëntatic op de mensenrechten manifesteert zich ook in de werking van het EVRM bij de toepassing van buitenlands recht. Bif rechtstreekse toepassing ervan is het begrip openbare orde weliswaar overbodig, maar het houdt een functie als het EVRM onvoldoende bescherming biedt, zoals in het geval van 
het lerse echtscheidingsverbod. Omgekeerd kan wreemd echtscheidingsrecht in veel ruimere mate worden getolereerd. als "openbare orde" in het licht van drie beginselen van mensenrecht wordt gezien. Weliswaar is volgens Strikwerda (1991) door de HR sinds 1973 een meer tolerante houding aangenomen, maar aan het Nederlandse echtscheidingsrecht wordt volgens hem nog steeds teveel exportwaarde toegekend. De drie beginselen wan mensenrecht zijn ook nuttig woor de beoordeling van de vraag of er een relatie met de Nederlandse rechtsorde bestaat. De fundamentele mensenrechten vormen de zogenaamde "buitengrens" van onze rechisorde, zoals geillustreerd wordt aan de hand van de zaak Soering/VK (Europese Hof 7 juli 1989, NJ 1990, 158, m.n. Alkema), waarin de Britse regering zich ten onrechte niet verantwoordelijk wilde achten voor een eventuele veroordeling tot de doodstraf van Soering na vitlevering aan de Verenigde Staten. Maar ook het omgekeerde, een terugdringing van de zogenaamde "binnengrens" kan worden bepleit in het licht van de drie beginselen van mensenrecht. Deze pleiten immers voor ruime erkenning van vreemd recht zoals bepaald door de keuzevrijheid van partijen als de eigen rechtsorde van de rechter niet serieus in gevaar is.

In het zesde hoofdstuk is de betekenis van het begrip "openbare orde" in het privaatrecht aan de orde. Volgens het oude BW had een overeenkomst die qua inhoud of strekking in "strijd met de openbare orde en goede zeden" was, een "ongeoorloofde oorzaak". Het begrip ongeoorloofde oorzaak komt in het nieuwe BW niet meer voor. Daar staat echter tegenover dat "volgens art. 3:40 BW thans bij alle rechtshandelingen de "openbare orde en goede zeden" gerespecteerd dienen te worden.

De relevantie van de drie beginselen wan mensenrecht zijn eenvoudig te illustreren aan de hand van belangrijke bepalingen van ons vermogensrecht. In feite zijn mijn drie beginselen van mensenrecht al in de dissertatie van. Nieuwenhuis (1979) grotendeels geïdentificeerd als de drie beginselen van het contractenrecht. Nieuwenhuis' autononie- en vertrouwensbeginsel correspondeert duidelijk met de begrippen vrijheid en trouw. Zijn derde beginsel, het causa-beginsel, geeft uitdrukking aan de verbondenheid van de prestaties van partijen in het licht van het doel wan de overeenkomst, dat niet alleen een aangelegenheid van partijen is, maar dat beperkt wordt door het algemeen belang. Het causa-beginsel correspondeert dus met het zorg-beginsel.

Geanalyseerd wordt hoe in het contractenrecht de drie beginselen van mensenrecht doorwerken in de begrippen "goede trouw", "redelijkheid en billijkheid" en (contractuele) "zorgvuldigheid" in de precontractuele - en de uitvoeringsfase. Het begrippenpaar "openbare orde en goede zeden" heeft betrekking op de zorgvuldigheid jegens de samenleving ten tijde van het sluiten van de overeenkomst, waarbij ook de waarden wrijheid en trouw in het geding kunnen zijn.

In het zevende hoofdstuk is het publiekrecht aan de orde. Het eerste thema betreft de politieke verenigingsvrijheid. De historische ontwikkeling laat enerzijds een steeds sterkere oriëntatie op de mensenrechten zien als criterium voor het eventuele verboden karakter van een politieke vereniging. Daarbij past dat sinds 1976 niet meer iedere strijdigheid met het recht van doel of werkzaamheden van een politieke vereniging voldoende reden is deze als verboden te beschouwen. 
Bovendien manifesteert zich de zowel afwerende als opleggende, rechtsbeschermende opvatting van het begrip openbare orde in het feit dat thans ingevolge art $2: 20 \mathrm{BW}$ de rechtbank een politieke vereniging tijdens de procedure de gelegenheid mag geven zijn statuten zo aan te passen dat deze niet langer in strijd geacht kunnen worden met de openbare orde en de goede zeden.

Het tweede thema wordt gevormd door de algemene beginselen van behoorlijk bestuur. Deze hebben historisch gezien yooral betrekking op de betrouwbaarheid en de zorgvuldig heid van het bestuur. Pas in het kader van de AWB is ook de bescherming van de procedurele autonomie van de burger meer op de voorgrond komen te staan. Betoogd wordt dat Van Gervens stelling (1983) dat de abbb gezien kumnen worden als nitwerking van algemene beginselen van (rechtens) behoorlijk handelen, tegen de achtergrond van de drie beginselen van mensenrecht goed bestand is tegen de kritiek van Nicolaï (1990).

Het derde thema is het politierechtelijk begrip openbare orde. Van der Meulen (1993) heeft betoogd dat dit betrekking heeft op de bewegingsvrijheid en slechts indirect op de geestelijke en lichamelijke integriteit alsmede op de vrijheid van meningsuiting. Naar mijn mening getuigt deze visie op een gebrek aan besef van de innerlijke verbondenheid van de drie beginselen van mensenrecht. Een al te vergaande bewegingswrijheid kan immers een bedreiging vormen van de andere genoemde vrijheden.

Het vierde en laatste thema van het zevende hoofdstuk is de betekenis van openbare orde in het strafrecht. Terwijl de overtredingen tegen de openbare orde en goede zeden nogal heterogeen van aard zijn, geldt voor de misdrijven onder die noemer dat ze duidelijk niet. alleen betrekking hebben op de openbare ruimte, maar ook op de private vrijheid en de menselijke waardigheid. Deze laatste is nog betrekkelijk recent versterkt met bepalingen gericht op de bestraffing wan discriminatie. De strijd rond de plaats van de verdachte in het strafprocesrecht tenslotte, laat zich heel wel interpreteren als een strijd on de openheid van het gesprek bij de strafrechter. Het begrip trouw kan een brugfunctie verwullen tussen de bescherming van de verdachte en de zorg voor een adequate strafvervolging.

In het achtste hoofdstuk zijn aspecten van het volkenrecht aan de orde. De idee van de innerlijke samenhang van de drie beginselen van mensenrecht is in overeenstemming met de WN-doctrine van de ondeelbaarheid van de mensenrechten. De enorme ontwikkeling en differentiatie van laatstgenoemden maakt de vraag naar hun onderlinge verhouding echter onvermijdelijk. Deze vraag wordt behandeld in verband met de plaats van de vrijheid van geweten. De ontwikkeling van de mensenrechten kar worden gezien als een proces van differentiatie van een aanvankelijk zuiver religieus opgevatte vrijheid van geweten in thet kader wan een op wederzijdse tolerantie en vreedzame omgang gerichte samenleving. Tegenover Vermealen $(1989,1992)$ wordt verdedigd dat de functie van de gewetensvrijheid als moeder van de mensenrechten nog niet is uitgeput. Vermeulens argument daarvoor is dat de gewetenswijheid oeverloos is en iedere beperking van mensenrechten. zou kunnen ondermijnen. Vermeulens argumentatic in dit verband voor een met zijn opvatting strokende interpretatie van art. 9 EVRM, wordt door mij bestreden. Vermeulens angst woor oeverloosheid is verwant met de vrees dat sociale rechten onmogelijk in to lossen verplichtingen voor de overheid zouden kunnen scheppen. 
In het licht van de innerlijke samenhang van de drie beginselen van mensenrecht lijkt deze vrees echter in principe ongefundeerd. Waar immers de zorgplicht van de overheid zo eenzijdig zou worden opgeval, zouden de vrijheid van het individu on de betrouwbaarheid van de relaties tussen de burgers onderling en tussen burgers en staat worden ondermijnd. Gegewen mijn visie hierop, verwerp ik dan ook de theorie volgens welke er een principieel onderscheid is te maken tussen klassieke en sociale grondrechten alsmede tussen de negatieve en de positieve verplichtingen van de overheid in verband met de mensenrechten. De juiste, maar verkeerd begrepen grondslag van dit door mij bekritiseerde onderscheid, is dat de individuele vrijheid steeds het uitgangspunt dient te zijn. Maar voor een principicel onderscheid is niettemin geen plaats, omdat trouw en zorg steeds in het licht van hun positieve bijdrage aan de vrijheid als maatschappelijk belang moeten worden bezien. Dit wordt geillustreerd aan de hand van art. $137 \mathrm{e} \mathrm{Sr}$. waarin de perswrijheid in relatie tot het discriminatieverbod atan de orde is in het begrip "zakelijke berichtgeving". Hier wordt weer de bemiddelende, op "trouw" gerichte funclie van het begrip "openbare orde ${ }^{\text {ss }}$ aangetroffen.

De innerlijke samenhang van de drie beginselen van mensenrecht manifesteert zich ook in het kader wan het EG-recht. Steyger (1994), die Vermeulens onderscheid tussen klassieke en sociale grondrechten accepteert, heeft betoogd dat het beginsel van de gelijke beloning voor gelijk werk voor mannen en vrouwen, geen sociaal grondrecht is, maar gewoon een toepassing van het klassieke gelijkheidsbeginsel. Dit is een voorbeeld van dichotomisch denken. Waar immers het gelijkheidsbeginsel door de vrije markt in onvoldoende mate wordt gerealiseerd, kan het beginsel als het tevens sociaalrechtelijk wordt opgevat de overheid legitimeren bij het nemen van aanvillende maatregelen om het principe beter te waarborgen. Omgekeerd beschouwt Steyger het recht op een veilige en gezonde arbeidsplaats als een sociaal grondrecht en niet als een mensenrecht. Dit recht is echter een direct uitvloeisel van het recht op lichamelijke integriteit. Ook hier geldt dat het én het ander niet uitsluit. Steygers bezwaren tegen sociale grondrechten zijn wan politieke aard. Zij vreest dat ze een anti-democratisch effect kunnen hebben. Wij daarentegen zijn juist bang dat de staat wel eens te machtig zou kunnen worden als zijn recht op ingrijpen niet gebaseerd is op de bescherming wan mensenrechten.

Het EG-recht is ook van belang in verband met het begrip "openbare orde". Steygers dichotomie wan mensenrechten en sociale rechten is vooral van belang in verband met de gelijkstelling van EG-migranten die geen EG-onderdanen zijn. Het is echter niet nodig daartoe een rechtstreeks beroep op de mensenrechten te doen. De interpretatie van het begrip "openbare orde" van art. 48 lid 3 van het EG-verdrag getuigt van een juist begrip van de algemene inzetbaarheid van het begrip, alsmede van de innerlijke samenhang van de mensenrechten tegen de achtergrond van de beginselen van mensenrecht.

In het afsluitende negende hoofdstuk wordt geconcludeerd dat de stellingen vruchtbaar zijn gebleken. Daarop aansluitend wordt nog aandacht besteed aan het begrip "alpartijdigheid". Terwijl het in het strafprocesrecht de daar heersende problematiek goed reflecteert, begint het in het bestuursprocesrecht meer op de voorgrond te treden. In het ipr lijkt meer ruimte te komen voor de private autonomie, terwijl deze in het privaatrecht juist terecht beperkt is waar machtsongelijkheid in de weg zou kumnen staan aan alpartijdigheid. 
Tenslotte getuigt de nog veelal heersende idee van een principieel onderscheid tussen klassieke en sociale grondrechten van een verkeerd begrip van alpartijdigheid.

Dan keren wij nog eens terug naar het tweede Geertruidenberg-arrest. In het licht van de drie beginselen van mensenrecht is het niet moeilijk aan te tonen dat zonder een beoordeling in concreto geen rechtvaardige beslissing in het gegeven geval mogelijk is. Het Arnhemse Hof, dat deze beoordeling wel gaf, steunde terecht het beroep van de kapelaan op art. 9 EVRM.

De drie beginselen vrijheid, trouw en zorg zijn in hun innerlijke samenhang te beschouwen als elementaire beginselen van mensenrecht ondat ze de meest basale morele aspecten van rechtens behoorlijk handelen in iedere rechtsorde onvatten. 



\section{Synopsis}

Der erste Teil (Kapitel 1-4) dieser Dissertation ist der Entwricklung einer an die Diskurstheorie Jürgen Habermas' anknippfenden Rechtsfindungstheorie gewidmet. Im zweiten 'Teil der Arbeit wird dann die Fruchtbarkeit dieser Theorie erprobt, wobei der Begriff "bifentlichen Ordnung" ("openbare orde") in den verschieden Bereichen seiner Verwendung im miederländischen Recht zentral stelut.

Im ersten Kapitel wird das Augsgangsproblem des Verhältnisses von formaler und materieller Rechtfertigung im Recht an Hand des sogenannten "zweiten GeertruidenbergUrteils" des höchsten niederländischen Gerichts, des "Hoge Raad der Nederlanden" (HR 19 Januar 1962, NJ 1962, 107) eingeführt. Es handelte sich hier un die Frage, ob ein Kaplan 2u Geertruidenberg zurecht in der vorherigen Instanz durch den Gerichtshof vom strafrechtlichen Vorwurf, widerrechtlich eine öffentliche Prozession veranstaltet zu haben, freigesprochen worden war. Die derzeitige niederländische Verfassung enthielt ein Verbot, Prozessionen zu veranstalten, die nicht schon vor der Verfassung won 1848 nach den damaligen Gesetzen und Vorschriften erlaubt waren. Erst 1983 ist diese Bestimmung abgeschafft worden. Der Kaplan berief sich auf seine Religionsfreiheit gemäB Artikel 9 EMRK. Diese Auffassung wurde durch das Urteil des Gerichtshofes bestatigt, weil das Verbot nicht als notwendig im Interesse der öffentlichen Ordnung erachtet werden könne. Der Hoge Raad war aber anderer Meinung. Das Verfassungsverbot sei zu respektieren, so lange die Regelung nach Maßsstab der Redlichkeit im Interesse des Schutzes der öffentlichen Ordnung sein könne. Mit anderen Worten, unwichtig war, ob das Verbot an Ort und Stelle und zu diesem Zeitpunkt notwendig ist, sondern ob es im allgemeinen und zur Zeit des Gesetzgebungsaktes als eine redliche Regeiung angesehen werden konnte. Der Hoge Raad ignorierte also völlig, daß das Verbot nach mehr als einem Jalurhundert fast uberall seinen Sinn verloren hatte, weil es zur völligen rechtlichen und gesellschaftlichen Gleichstellung der Katholiken in den Niederlanden gekommen war.

Die Frage, die nach Anlaß dieses Falles zu Beginn der Arbeit gestellt und am Ende der Arbeit wieder aufgegriffen und beantwortet wird, ist wie man juristisch darlegen kann daß die Entscheidung vom Hoge Raad eine Sanktion won Unrecht war. Die Entscheidung weranlaßst die Autorin, den inneren Wertbezug des Rechtsbegriffs auf die öffentliche Ordnung, die Menschenrechte und die Demokratie zu beziehen und in ihrem Zusammenhang zu darzulegen.

Antizipierend auf den zweiten Teil der Arbeit, werden im ersten Kapitel zwei Thesen zum Begriff "offentliche Ordnung" aufgestellt. Die erste These ist, daß der Begriff "gffentliche Ordnung" allgemein einsetzbar ist. Im Gegensatz zu dem, was das Geertruidenberg-Urteil suggeriert, ist der Begriff nur im Zusammenhang mit den der Rechtsordnung zugrunde liegenden Werten richtig und voll zu verstehen. Die zweite These ist das "Menschenrecht" den moralischen Kern des westlichen Rechts ausmacht. Unter "Menschenrecht" wird die den Menschenrechten zugrunde liegende Idee verstanden. 
Sie liegt nicht nur den Menschenrechten zugrunde, sondern auch dem Demokratie- und dem Rechtsstaatsprinzip. Es ist dieser Kem, der wie z.B. im Geertuidenberg. Urtell, an den an reine Herrschaft orientierten Begriff "offentliche Ordnung" eine viel komplexere Bedeutung verletht. So wird dieser im Wertungszusammenhang auch fir Rechtsverhälnisse 2wischen Bügern und ebenso zum Rechtsschutz von Bürgern gegen die Obrigkelt verwendet. Diese an sich positive Entwicklung ist aber nicht ganz ohne Gefahren. Man muB darauf bedacht sein, daß Menschenrechte letztlich nur von der kollektiven Ordnung erfalt werden und nicht in ausreichendem Masse in inrer die individuelle Freiheit und ihe soziale Basis als solche schutzenden Funktion. Damit die Idee Menschenrecht besser erfabbare und anwendbar wird, ist in dieser Arbeit versucht worden, sie in dre Prinzipien zu konkretisieren: Freiheit, Treue und Sorge.

Das zweite Kapitel beginnt mit der Frage, ob diese radikale Auffassung von Demokratie nicht impliziert, daß jeder Inhalt von Recht im Prinzip von den Burgern selbst als auf demokratische Art und Weise veränderlich hinterfragt werden kann. Wenn dies so wäre, wurde das auch die Menschenrechte mit einschlieben. Die im ersten Kapitel gestellte Frage könte dann auf relativ einfache Weise beantwortet werden. Recht und Redlichkeit ist dann identisch mit dem Endergebnis einer demokratischen Debatte. Eine in diese Richtung tendierende Theorie der Rechtsfindung und des Verhältnisses von Richter und Gesetzgeber wurde noch nicht allzulange von Basendrecht (1992) in einer relativ viel Aufsehen erregende Dissertation "Recht als model van rechtvaardigheid" vertreten. Grund dieses Autsehens war sein Angriff auf die s.E immer starker werdende Tendenz der Einzelfallgerechtigkeit in der modemen niederländischen Rechtsprechung auf Basis vager Begriffe, die s.E. das präliktive Vermögen des Rechts untergraben. Eine rationale Rechtsentwicklung, die anknüpt an was an Gerechtigkeit in Gesetz und Jurisprudenz schon verkörpert ist, würde dadurch frustriert. Nach Barendrecht's an wissenschaftstheoretischen Modellen van Popper (Falsifikation) und Lakatos (Research Programme) anknüpfenden Vorschlag, soll die Rechtsprechung programmatisch verfahren, d.h. sich quasi-gesetzgeberisch in vom Gesetz nicht geregelten Fullen verhalten. Neue Falle können natürlich dazu führen, daß ein bestehendes richtertiches Entscheidungsprogramm für ein neues und besseres eingetauscht werden muß. Man kann Barendrecht's Theorie als eine moderne Version der Theorie des Gewohnheitsrechts ansehen, weil er der Philosophie jeden Eigenwert fur die Rechtsprechung abspricht und dem Gesetzgeber, ohne ihm das stattsrechtliche Primat abzusprechen, ein rezeptives Verhältnis zur Jurisprudenz unterstellt. Dies ist ubrigens jedenfalls in dem von ihm analysierten Teilen des niederländischen privatrechts, das in 1992 gerade in einem newen Burgerlichen Gesetzbuch kodifizient worden ist, auch vollig realistisch.

Die Kritik der Autorin an Barendrecht betrifft nicht seme Beschwerden gegen eine die Transparenz des Rechts lahmende Einzelfallgerechtigkeit. Insofern dies mit Hilfe vager Nomen geschieht, wird dies von ihr aber eher als ein MiBbranch dieser Normen angesehen. Sie möchte diesen ebensowenig wie der Rechtsphilosophie nicht jeden Erkenntniswert fir Gerechtigkeit in der Jurisprudenz absprechen. Interessanterweise verweist Barendrecht an Ende seiner Arbeit auch auf Jurgen Habermas" Diskurstheorie als eine Möglichkeit Gerechtigkeit nâher zu bestimmen. Er unterschlagt dabei aber, dab die subjektive Aufrich. tigkeit zu Einzelfallgerechtigkeit als Resultat eines dialogischen Prozesses fuhrt. 
Insoweit Barendrecht einen lehren Begriff won Gerechtigkeit befurwortet, bedeutet dies, daB er keinen inneren Zusammenhang zwischen Demokratie und einem bestimmten Inhalt der Rechtsidee unterstellt. Dagegen wird won der Autorin ein solcher Zusammenhang angenommen, wonach die Frage nach dem Primat von einen von beiden, in Prinzip irrelevant ist. Die Plausibilität dieser Annahme wird durch die Korrespondenz der Idee der Offenheit des Diskurses und der Idee der Öfentlichkeit in der Demokratie begründet. Die Offenheit des Diskurses beinhaltet schon auf dem empirischen Niveau des altaglichen Gesprächs eine prinzipielle Anerkennung von menschlicher Freiheit und Würde. Diese Anerkennung ist impliziert in den von den Gesprächsteilnehmem immer schon vorausgesetzten Bedingungen eines auf Verständigung zwischen ihnen zielenden Gesprächs. Diese Bedingungen sind: Abwesenheit von Zwängen, eine Aufgeschlossenheit für Kritik und Aufrichtigkeit.

Die prinzipielle Anerkennung menschlicher Freiheit und Würde ist der moralische Ken der Idee von Menschenrecht und zugleich der Kern einer im Gesprächsmodell fundienten Auffassung von Demokratie. Dieser Grundgedanke der Arbeit macht die Frage nach dem Primat von Menschenrecht und Demokratie in Prinzip irrelevant. Ausgehend von diesem Gedanken wird der interne Zusammenhang von der Idee der Menschenrechte und der Demokratie aus der politischen Philosophie der Moderne (Hobbes, Locke, Rousseau und schlieBlich Kant) rekonstruiert, auf welche Habermas aufgebaut hat. Bei him kommt der schon von Rousseau und Kant vermutete interne Zusammenhang von Menschenrecht und Demokratie in der normativen Qualität der Ausübung offentlicher Autonomie zum Ausdruck.

In dritten Kapitel wird dargestellt, wie Habermas die Idee der Gleichursprünglichkeit privater und öffentlicher Autonomie Schritt für Schritt in einem System von subjektiven Rechte rekonstruiert hat, beginnend mit privaten Handlungsfreiheiten, gefolgt won den Assoziationsfreiheiten, anschließ3end der Rechtsschutz und die politischen Rechten und zum Schluß soziale Rechte als Bedingung der Möglichkeit des materiellen, sozialen und ökologischen Überlebens.

Diese Rechte sind Bedingungen eiter von legitimen Recht geregelten Gesellschaft. Es sind diese Rechte, welche die Vorbedingungen einer offenen Kommunikation in der Lebenswelt auf der Systemebene der Gesellschaft reproduzieren und diese ais eine offene, demokratische Gesellschaft konstituieren. In diesem Zusammenhang tancht die Frage vom Verhältnis von privater und öfentlicher Autonomie und die Realität politischer Macht auf. Die Legitimitat des Rechts und seines sozial-integratives Potentials ist entscheidend bedingt durch die Ausübung öffentlicher Autonomie von den Rechtsgenossen. Weil die Qualität der Offentlichkeit hier bestimmend ist, wird der Begriff der Öfentlichkeit näher erb̈rtert. Die innerliche Anfalligkeit einer konsequent an Freiheit orientierten demokratischen Rechtsordnung wird dargestellt und erörtert.

Wie steht es nun mit der Offenheit des Gesprächs vor Gericht? Davon ausgehend, daß drese besteht, wird analysiert, welche Anforderungen diese Offenheit des Gesprächs an den Richter stellt. An erster Stelle sollte der Richter sich im Verhältnis zu den Parteien, trotz deren instrumentellen und strategischen Absichten, im Prozeß 3 auf kommunikative 
Rationalităt einstellen und soll er versuchen, die Parteien dazu ebenfalls zu (ver)futhren. Dieses Verfahren zielt letztich auf ein auf ubberzeugende Weise zu begrundendes Urteil. Das richterliche Bemühen um zu überzeugen betrifft nicht notwendiger Weise die Gerechtigkeit der Entscheidung in einem absoluten Sinne. Es kann auch die Abhängigkeit des Richters von einem eventuell auch nach dem Urteil des Richters ungerechten positiven Recht darlegen; eines Rechts, das dennoch anzuwenden ist, soweit die Gebundenheit des Richters daran zu rechtfertigen ist. Von einer relativen Rechtfertigung des Urteils wäre auch dann noch zu sprechen, wenn der Richter einer seinem Urteil nicht zustimmenden Partei darlegen kam, in welcher Hinsicht die Gerechtigkeitsurteile beider auseinander laufen. Des offeren impliziert dies eine Darstellung der Differenz zwischen verschiedenen Gerechtigkeitsurteilen: der Lebenswelt einerseits und der vom Recht vermittelten und im Recht reflektierten Systemwelt andererseits. Dies unterstellt jedoch, daß das Recht im Prinzip eine Verbindung hat zur lebensweltlichen Gerechtigkeit.

Unterstellen wir diese Möglichkeit, dann impliziert dies für die Heuristik der richterlichen Urteilsbildung, daf sich der Richter bemühen soll, sich eben so sehr in die Vorstellung und Beurteilung des Falles durch die Parteien zu versetzen, als daß er auch versuchen mu 3 , eine aus dem Rechtssystem aufgearbeitete Perspektive auf den Fall zu entwickeln. Diese Fähigkeit und dies Bemulthen wird von der Autorin unter Berufung auf Van der Burg (1991) "Allparteilichkeit" genannt. Wie bereits festgestellt, geht es dabei nicht um eine einfache Nebeneinanderstellung dieser verschiedenen Perspektiven, sondern um den Versuch, sie aneinander zu relatieren. Diese geht einher mit der Begründungslast, für die in Deutschland eine besondere "Relationstechnik" entwickell wurde. Dort gilt diese Relationstechnik bei der Unteilsfindung als eine Selbstverständlichkeit, wogegen sie z.B. in den Niederlanden als solche gar nicht bekannt ist. Es wäre aber ein Mißverständnis Allparteilichkeit als eine rein technische und rein intellektuelle Angelegenheit zu betrachten. Rechtsprechung in verhältnismäßig komplizierten Fällen ist nicht aus einer rein observierenden Perspektive des Richters vollziehbar. Bevor er letztlich urteilt, ist auch der Richter Teilnehmer am Rechtsgespräch. Auch die praktische Fähigkeit des Richters mit den Parteien zu kommunizieren, sein Rechtsgefühl, so wie seün Vermögen Pro- und Kontraargumente gleichmäßig abzuwägen, sind hierbei angesprochen. Offensichtlich korrespondieren Kommunikationswermögen, Rechtsgefuh」 und Abwägungswermögen mit den drei von Habermas bestimmten Wesensmomenten kommunikativer Rationalität: Sinn für Wahrheit, normative Richtigkeit und subjektive Aufrichtigkeit. Unklàr aber ist immer noch, worcouf sich diese Tugenden denn in sachlicher Hinsicht beziehen sollen.

Das vierte Kapitel beginnt mit der Feststellung, daß Habermas eine Antwort auf diese Frage nicht auf Basis seiner Diskurstheorie entwickelt hat. Er hat seine These der Gleichursprünglichkeit privater und öffentlicher Autonomie nur in Bezug auf die Demokratietheorie ausgearbeitet, eine Theorie der politischen Allparteilichkeit jedoch nicht fur eine Theorie der Rechtsanwendung. Eine Theorie der juristischen Argumentation, wie sie z.B. Alexy unter Bezugnahme auf Habermas an seine Theorie angeknüpf, reicht dazu nicht aus. Diese Theorie ist kaum mehr als eine Anwendung von allgemeinen Argumentationsregeln des moralischen Diskurses auf die rechtliche Argumentation. Gefordert ist vielmehr ein juristischer Begriff von Gerechtigkeitsperspektiven, der die Rechtsfindung steuern kann. Vom Gesichtspunkt der Privatautonomie zielen subjektive offentliche Rechte 
nicht notwendigerweise auf Partizipation an der Öfentlichkeit ab, sondern im Gegenteil auf ein Recht, sein Leben nach eigener Sicht zu fuhren und eigene Interessen statt kollektive zu verfolgen. Wenn aber private und öfentliche Autonomie tatsächlich gleichursprünglich gedacht werden soliten, muß auch private Autonomie einen innerlichen Bezug zur offentlichen Autonomie, der gesellschaftlich-rechtichen Position des Menschen haben.

Zur Entwickiung eines Begriffs dieser Beziehung von privater Autonomie auf Gesellschaflichkeit werden von der Autorin erst alternative Theorien demokratischer Allpartilichkeit auf ihre Anwendbarkeit auf juristische Allparteilichkeit untersucht. Insbesondere bezieht sie sich auf die Theorie Van der Burg's, der den Begriff der Allparteilichkeil zuerst verwendet hat. Mit Habermas gegen einen abstrakten Begriff der Unparteilichkeit argumentierend, wie man ihn bei Baier und besonders in Rawls" Prinzip des "Schleiers der Unwissenheit" antrifft, hat Van der Burg den Begriff der Allparteilichkeit zur Andeutung der Forderung entwickelt, daß im politischen Prozeß alle Betroffenen partizipieren. Er hat dabei die Gründe und den Sinn einer Entscheidung aufgezeigt sowie, dall die Ausführbarkeit eines Entscheidungsworschlages und insbesondere dessen Konsequenzen fur die verschiedene Gruppen von Betroffenen und Interessenten, dargelegt werden müssen. Van der Burg folgert dies aus den von Dworkin als Grundnorm einer demokratischen Gesellschaft betrachteten Prinzips von "equal concern and respect". Obwohl dieses Prinzip auch unmittelbar auf richterliche Allparteilichkeit anwendbar ist, fur den Dworkin es ja auch an erster Stelle entwickelt hat, geht daruber der Bezug zum diskurstheoretischen Gesichtspunkt der freiwilligen Akzeptanz verloren und führt daher nicht zu einem ausreichenden Verständnis des Begriffs einer juristischen Alparteilichkeit Kommentare von Van Roermund und Holmaat fungieren als zwei Brücken zwischen privater and offentlicher Autonomie und damit als Weg zum Begriff der juristischen Allparteilichkeit. Van Roermund hat Habermas auf Grund seiner Betrachtung des Systemcharakters der Politik im Verhältnis zur kommunikativen Rationalität kritisiert. Habermas schrieb in "Faktizität und Geltung" (S. 374):

"Aber die kommunikative Bewältigung dieser Konflikte bildet in einer säkularisienten Gesellschaft, die mit ihrer Komplexität auf bewaßte Weise umzugehen hat. einzige Quelle fur eine Solidaritat tmer Fremden - unter Fremden, die auf Gewalt werzichten whit die sich, bei der kooperativen Regehung ihres Zusammenlebens, auch das Recht zugestehen, fur einander Fremde zu bleiben."

Van Roermund meint, daß Habermas hier Luhmann und den rein funktionalen Charakter des modernen Rechts konzediert und ihn daher im Bereich einer instrumentellen und strategischen Rationalitât einordnet, dessen Bezug zu der dem Recht unterstellten kommunikativen Rationalităt von Habermas nicht geklärt ist. Die Autorin ist dagegen der Meinung, daßß dieser Bezug sich aus der Sicht Habermas' aus der Gleichursprünglichkeit und funktionaler Komplementaritat von privater und öffentlicher Autonomic erklären läßt. Genauso wie im demokratisch-politischen Diskurs innerhalb gewisser Grenzen die Partikularität der politischen Interessen durch Verhandlung im demokratischen Entscheidungsprozeß vermittelt werden kann, genau so kann im Recht einer bürgerlichen Gesellschaft ein strategischer Einsatz von Recht akzeptiert werden, solange die menschliche Würde davon nicht fundamental in Frage gestellt wird. 
So ist cs z $\mathrm{B}$ erlaubt, andere bankrot zu konkurrieren gerde well das offentliche Recht die Folgen solchen Handelns durch sozialrechtiche Regelungen absichert. Das Sozialrecht komplementiert eine Rechtertigung wines die wirtschaftiche Privatuntonomic stitzenden Rechts in Zusammenhang mit dessen wirtschatticher Funktion der kollektiven Wohlfahrtsgteigerung. Sowohl im politischen als im juristischen Diskurs ist also, anders als in rein moralischen, keine völlige Identifikation von Subjekten gefragt. Das Beispiel ist zugleich geeignet Habemas" These der Vemittlung von Lebens- und Systemwelt durch Recht zu konkretisieren.

Wie bereits dargelegt, ist die Offenheit kommunikativer Rationalität für instrumentelle und strategische Rationaliät die einen Freihertsbegriff widerspiegelt, worin der andere als anderer in seiner konkreten gesellschaftichen Existenz anerkannt wird, eine relative, weil das Recht ja auch die Gegenseitigkeit dieses Verhälnisses und die elementare menschliche Wurde zu verburgen hat. Diese Uberlegung wird von der Autorin in Zusammenhang gebracht mit einer feministisch inspirierten Kritik Holtmaat's einfacher Dichotomien im Recht, wie z.B. zwischen Recht und Bedurfnis. So kann das Recht eines Bankrotteurs auf Sozialunterstutzung nicht nur als ein Anspruch auf Versorgung gesehen werden, das als ein Abhängigkeitsvertuälnis zu charakterisieren wäre, da diese Unterstützung durch den Staat ja gleichzeitig die soziale und politische Unabhängigkeit verbürgt. Recht als subjektive Freiheit und Sorge sind also vermittelt im Recht. Dasselbe gilt fit die Gleichheit im Sinne der Gegenseitigkeit, wie z.B. im Primzip der Vertragstreue, die nicht nur als Beschrånkung der subjektiven Freineit, sonderı auch als ihre gesellschaftich-funktionale Bedingung betrachtet werden kann.

Anschließend werden Freiheit, Treue und Sorge als drei Prinzipien von rechtsondentlichem Handeln abgeleitet aus der Diskurstheorie im Zusammenhang mit dem Begriff der Allparteilichkeit. Sie fundieren den inneren Zusammenhang von privater und bffentlicher Autonomie und zeigen, daß thre Gleichurspringlichkeit nicht nur ein funktionaler, sondern ein in der Diskursmoral werwurzelter ist. Dabei geben sie auch den rechtsepistemologischen Ralmen sowohl für das Verfahen wie für die Zielsetzung der Rechtsanwendung. Im Freiheitsbegriff kommt die Idee der individuellen Selbstbestimmung als Ausgangspunkt jedes modernen Rechtsdiskurses zum Ausdruck. Sie reflektiert die implizite Anerkenmung des anderen als anderen im herrschafstreien Diskurs und ist das Leitprinzip auf das die anderen zwei Primzipien zurick zu beziehen sind. Im Begriff der Treue, der Preis der Freiheit sozusagen, wird die Gebundenheit an die Kriterien theoretischer und praktischer Rationalitat reflektiert. In Begriff der Sorge schleßlich wird die materielle Bedingtheit der Herschaftsfreiheit im Diskurs angesprochen.

Es wird gezeigt, daf die drei Primzipien rechtsordentlichen Handelns in Stande sind, Habermas. und Van der Burg's Demokratietheorie abzudecken. Es wird aber auch deutlich, dab das im Dworkinischen Prinzip von "equal concern and respect" die Treue nur indirekt als Prinzip angesprochen wird. Dworkin unterschlägt damit die Positivitat des Rechts, die er anderswo dann wieder muhsam durch Anwendung seines Konzepts won "integrity" aufrecht $z u$ crhalten wersucht. Eine nahere Bestimmung der drei Prinzipien rechtsordentichen Handelns als drei Prinzipien von Menschenrecht ist als moralischer Aufuf innerhalb des Rechts zu betrachten, wo Freiheit, Treue und Sorge, als allgemeine 
moralische Aspekte menschichen Zusammenlebens, Rechtsschutz bedüfen. Soweit private and offentliche Autonomie durch Freheit, Treve und Sorge inmerlich vertunden sind, bedeutet dies kemeswegs, daß sie nicht in emem Spannungsverhältwis zueinander stehen kömnen und der abwägenden Wertung unterworfen werden müssen. Dies gill insbesondere bei der Arwendung des Begriffs der offentlichen Ordnung, dessen komplexe Bedeutung anzusprechen nur dann möglich ist, wenn alle drei Ecken der vorgeschlagenen diskursiven Rechtsepistemologie gleichermalen und in dynamischer Weise in Betrach gezogen werden. Diese Einsicht wird in einer These des internen Zusammenhanges der drei Prinupien von Menschenrecht zum Ausdnok gebracht.

Im zweitex Teil der Arbeit (Kapitel fün bis acht) wird die Fruchtbarkeit dieser Rechtsfindungstheorie erprobt und die Methode ihrer Anwendung durch eine Analyse des Begriffes der offentlichen Ordnung in verschiedenen Bereichen des niederländischen Rechts demonstriert. Dabei soll vor allem die allgemeine Einsetzbarkeit des Begriffs "ôffentliche Ordnung" (These 1) aufgezeigt werden, so wie dessen Bezug auf Menschenrecht (These II). Was den methodischen Aspekt betriff wird dan auch die These der internen Ab. lnängigkeit der drei Prinzipien von Menschenrecht auf die Probe gestelli.

Das finfte Kapitel ist dem Internationalen Privatrecht gewidnet. Der Begriff "offentliche Ordmung" spielt hier schon seif Jahrhunderten eine Doppelrolle. Es exfullt einerseits eine Abwehrfunktion, wodurch fremdes Privatrecht nicht nach den geltenden Verweisungsregetin angewendet werden braucht. Andererseits erfillt es eine aufarlegende Funktion, wodurch das die eigene "öfrentliche Ordnung" konstituierende Recht angewendet werden kann.

Schon in Kranenburgs Dissertation (1895) kơnnen Elemente der drei Prinzipien von Menschenrecht aufgezeigt werden. Kranenburg argumentiert, dals das Prinzip "öfentliche Ordnung" in allen Rechtsgebieten dieselbe abwehrende und auferlegende Wirkung hat mit einem Bedeutungskem, der auf die individuelle menschliche Freiheit abzielt. Sorge ist nach Kranenburg ebenso ein Teil dieses Kerns und zielt auf den Schutz von sozial Schwacheren ab. Das Prinzip der Treue kommt bei Kranenburg als prozessuale Zuverlassigkeit vor: Rechtssicherheit, die von inm noch als Gesetzestreuc aufgefaßt wird. Eine immer weitergehende Joslosung von Kranenburgs Idee dahimgehend, daf "öfentliche Ordnung" mur als eine Eigenschaft won Gesetzen zu betrachten ist, karn uber Autoren wie Hijmans (1937) und Van Brakel (1953) verfolgt werden. Nach van Brakel bezieht der Begriff sich auf "die (sitlichen, R.B.) Grundlagen der Rechtsordmung". Noch wetter von enem gesetzespositivistischen Vorverstundnis hat sich der Begriff gelost, indem auch dass semi offentliche Recht, das bislang per definitionem als Recht offenthcher Ordnung galt, aber nach dem Alnati-Urteil (HR 13 mei 1966, NJ 1967, 3, m.n. H.B.) von Vorrangsregeln beherscht wird. Verheul (1973) befurwortet dan letulich einen völig von nationalen Rechtsordmungen losgelosten Begriff offentlicher Ordnung, der an Menschenrechten orienthert ist, auf die, wie er gezeigt hat, auch die soeben genannten Vorangsregeln rekurrieren. Nach Ansicht von Polak (1990) hat sich en solcher Begriff offentlicher Ordnung fatsächlich in der niederlandischen Rechtsprechung durchgesetzt. Diese Entwicklung kann im Rahmen der im ersten Teil dieser Arbeit aufgefuhten drei Prinzipien von Menschenrecht interpretiert werden. 
Die Entfernung vom nationalem Recht in der Anwendung des Begriffs und dessen Ausrichtung auf Menschenrecht, zeigt sich auch in der Wirkung der EMRK, wenn die Anwendbarkeit fremden Rechts zur Diskussion steht. Wenn die EMRK angewendet wird, ist aber der Begriff der offentlichen Ordinung nicht notwendig. Er behält aber eine Funktion, wenn die EMRK keinen ausreichenden Schutz bietet, wie z.B. im Falle des irischen Ehescheidungsverbots. Obwohl Treue und Sorge selbstverständlich auch im Ehescheidungrecht Rechtswerte von großer Bedeutung sind, sollte ein niederländische Richter ein praktisch kategorisches Ehescheidungsverbot unvereinbar mit dem Freiheitsprinzip erachten. Umgekehrt kann, wenn von einem Konflikt mit den drei Prinzipien nicht die Rede ist, fremdes Ehescheidungsrecht gerade in viel umfassenderen Masse toleriert werden als jetzt der Fall ist. Eine liberalere Tendenz hat die Rechtsprechung des HR hier zwar seit 1973 eingeleitet.

Nach Ansicht von Strikwerda (1991) ist das niederländische Ehescheidungsrecht aber noch immer durch eine zu große Vorliebe gekennzeichnet, sich selbst zu exportieren. Die drei Prinzipien sind auch aufschlufreich, wenn es um die Frage geht, inwiefen ein Bezug zur Rechtsordnung des urteilenden Richters besteht. Der Unterschied zwischen der sogenannten Außengrenze der offentlichen Ordnung wird im Sinne der absoluten Verwerflichkeit fremden Rechts definiert. Die fundamentalen Monschenrechte geben die Substanz dieser Grenze ab. Diese ist auch dann wirksam, wenn das frende Recht nicht innerhalb der eigenen Rechtsordnung wirkt, sondern nur als Folge einer in der eigenen Ordnung getroffene Entscheidung, wie z.B. im Fall Soering/VK (Urteil des Europäischen Gerichtshofs für Menschenrechte vom 7. Juli 1989, NJ 1990, 158, m.n. Alkema) in dem die englische Regierung sich bei einem eventuellen Todesurteil nach Auslieferung Soerens in die Vereimigten Staaten der Verantwortung zu entziehen versuchte. Aber auch die ungekehrte Dringlichkeit, die Anerkennung und Durchsetzung fremden Rechts, die sogenannte "Innengrenze" der öfentlichen Ordnung, ist mit Hilfe der drei Prinzipien zu bestimmen. Der Freiheitsbegriff erfordert einen weiten Raum für Privatautonomie, solange die Rechtssicherheit und die materielle oder soziale Position der Parteien innerhalb der eigenen Rechtsordnung des Riclaters nicht ernsthaft bedroht ist. Im Europäischen Schuldrechtsabkommen (EVÜ)! ist eine vom Alnati-Urteil inspirierte Differenzierung des Begriffs $z u$ finden, die sich im Rahmen des Vorhergehenden gut verstehen läßst. Nach diesen Vertrag gibt es drei Kategorien zwingenden Rechts, die die Parteiautonomie durchbrechen können. Die erste Kategorie betrifft das Konsurnentenrecht und das Arbeitsrecht, wobei die Gesichtspunkte der Treue und Sorge voranstehen. Die zweite Kategorie bezieht sich atuf die schon genannten Vorrangsregeln, deren Sinn sich ebenso auf Grund der drei Prinzipien verstehen laßt. Schließlich verwenclet das Schuldrechtsabkommen einen Begriff der offentiichen Ordnung, der als die sittlich-rechtliche Grundlage der Gesellschaft im Sinne von Van Brakel angesehen wird.

In sechsten Kapitel wird die Bedeutung des Begriffes im Privatrecht untersucht, wobei das Vertragsrecht zentral steht. Das niederländische Bürgerliche Gesetzbuch van 1838, das bis 1992 gegolten hat, qualifizierte einen Vertrag dessen Inhalt oder Absicht strittig war mit

1 Ubereinkommen iber das auf vertragliche Schuldverhältnisse anzuwendende Recht vom 19. Juni 1980 . 
der "openbare orde en goede zeden" als ein Vertrag mit einer umerlaubten Causa. In dem ab 1992 geltenden neuen Bürgerlichen Gesetzbuch figuriert die causa nicht melhr. Dagegen müssen jetzt nach Artikel 3:40 BW nicht nur bei Vertragen, sondern bei allen Rechtsgeschäften die "openbare orde en goede zeden" respektiert werden.

Die Relevanz von Freiheit, Treue und Sorge laBt sich an wichtigen Artikeln des Bürgerlichen Gesetzbuches leicht aufzeigen. Die drei Prinzipien sind in der Dissertation von Nieuwenhuis (1979) schon größtenteils als die drei Prinzipien des Vertragsrechts identifiziert worden: das Autonomieprinzip, das Vertrauensprimzip und das Causaprinzip. Letzteres ist Ausdruck der Verbundenheit der Parteien in der sachlichen Vertragsleistung und dessen Zweck, der beschränkt von "openbare orde en goede zeden" eben nicht nus Privatsache der Parteien ist, sondern auch das rechtliche Algemeininteresse der Gesellschaft berührt. Das Causaprinzip korrespondiert also mit dem Prinzip der Sorge.

Es wird analysiert, wie im niederländischen Vertragsrecht die drei Prinzipien in den Begriffen "goede trouw, redelijkheid en billijkheid en (contractuele) zorgvuldigheid" wirksam sind in der vorvertraglichen Phase sowie in der Ausfuhrungsphase des Vertrages. Das. Begriffspaar "openbare orde en goede zeden" bezieht sich dagegen auf die Sorgfäls" pflicht gegenüber der Gesellschaft zur Zeit des Abschlusses des Vertrags, wobei die geschüizten gesellschaftlichen Rechtsinteressen durchaus auch die Freiheit oder die Troue sein körnnen.

Im siebten Kapitel wird das öfentliche Recht untersucht. Zunächst bezieht sich die Untersuchung auf das politische Vereinsrecht. Seit der Verfassung von 1848 ist dieses Recht in der Hinsicht begrenzt von der Bedingung, daß ein politischer Verein nicht gegen die öffentliche Ordnung verstoßen darf. Nach dem Gesetz von 1855, worin diese Materie näher ausgearbeitet wurde, lag ein solcher Verstoß vor, wenn ein politischer Verein die Absicht hatte, Gesetze, Rechte oder die guten Sitten zu verletzen. Dabei wurde auch noch ein Filter eingebaut, indem einem politischen Verein die Rechtspersönlichkeit auf Grund des Algemeininteresses entsagt werden konnte. Zum förmlichen Verbot eines Vereins ist es nur einmal gekonmen und zwar in 1894, im Falle des tatsächlich mit revolutionären Absichten gegründeten "Sociaal-Democratische Bond". 1939 ist das Verbot, inspiriert von einem durch Var den Bergh in 1936 verfaßten Aufsatz uber undenokratische Parteien angeschärft worden. Seit 1939 ist nicht nur der formelle Zweck solcher Parteien ausschlaggebend, sondem können auch die Aktivitäten eines politischen Vereins zum Anlaß ilires verbotenen Charakters werden. Dieses Urteil muB abrigens vom bürgerlichen Richter ausgesprochen werden. Ausdrücklich wurde dabei der dem positiven Recht unterlegte Rechtsstaatsgedanke als die Grundlage der offentlichen Ordnung genanmt. Seil 1976 ist die ganze Thematik im zweiten Teil des Bürgerlichen Gesetzbuch geregelt. Genäß Artikel 2:15 sind alle Rechtspersonen verboten, deren Absicht oder Bestreben as ist, die öffentliche Ordnung oder die guten Sitten zu verletzen. Die Bedeutung dieser Bestimmung ist im Prinzip keine andere als die bereits 1939 geregelle.

Die Tatsache, daß seit 1976 nicht mehr jeder Verstoß gegen Gesetz oder Recht Anlaß sein kann, einen politischen Verein als verboten zu betrachten, zeugt u.E. von einer adäquateren Auffassung des Begriffs der öffentlichen Ordnung. 


\section{Synopsis}

Das gill atch fur die Anerkennung einer nicht nur abwehrenden, sonderin auch einer aufer legenden, rechisschützenden Funktion der öffentlichen Ordnung. Nach Artikel $2: 20$ des Bügerichen. Gesetzbuches kann das Gericht einen politischen Verein erlauben, seinen Zweck so abzuăndern, dab er nicht länger einen verbotenen Charakter hat.

Das zwe The Tha des Kapitels sind die allgemenen Prinzipien des Verwaltungsrechts. The Entwicklungsgeschichte im niederlandischen Recht zeigt, daß sie sich zunächst auf die Zuverlassigkeit und Sorgfalt der Staxtswerwaltung beziehen. Der Schutz der Freiheit der Birger tritt erst in den letzten Jahren mehr in den Vordergund, zumal in der Diskussion uber den aduquaten prozessualen Verwalungsrechtsschutz in Rahmen des seit 1992 in Phasen verabschiedeten "Algemene Wet Begturisrecht". Nicolai (1990) hat die These Van Gerven's (1983), dal3 die allgemeinen Prinzipien des Verwaltungsrechts sich als Ausdruck allgemeiner Prinzipien rechtsordnenden Handelns verstehen lassen, kritisiert. In der vorliegenden Studie wird dagegen argumentiert, daB sich Van Gerven's These jedenfalls auf Grund der drei Prinzipien gut gegenủber Nicolä"s Kritik verteidigen lassen.

Das dritte Thema des Kapitels ist das Polizeirecht und insbesondere die Handhabung der offentlichen Ordnumg im polizeirechtlichen Sinne. Van der Meulen (1993) meint, daB dessen Handhabung sich auf. Bewegungsfreiheit bezieht, nicht aber auf geistige und körperhiche lntegrität so wie auf die Meinungstreiheit, die nur als folge von der Bewegungsfreiheit polizeilich geschützt warren. Der Autorin erscheint dies als ein zu enger Begriff der offentlichen Ordnung, gerade weil ein schrankenloser Scinutz von Bewegungsfreiheit die beiden anderen Momente individueller Freiheit in Gefahr bringen kann.

Als letztes Thema des siebten Kapitels wird das Strafrecht einer Befrachtung unterzogen. Zwar findet man unter den leichteren Delikten gegen die "öffentliche Ordnung und guten Sitten" sehr heterogene Bestimmungen. Bei den schwerwiegenderen tritt deutlich hervor, daß sich die offentliche Ordnung nicht nur auf den offenthichen Raum bezieht, sondem auch auf die Privatautonomie und die Menschenwinde. Zum letzteren gehören auch die relativ neuen Bestimmungen gegen Diskriminierung aufgrumd ethnischer Herkunft, religioser oder weltanschaulicher Uberzeugung, Geschecht und sexueller Veranlagung.

Im niederbandischen Strafprozebrecht hat in den letzten Jathen ein Kampf um die Aufrechterhaltung der strafrechthchen Rechtsschutzgarantien getobt. Dieser labt sich durchaus als ein Kampf um die Offenheit des Gesprächs vor Gericht interpretieren, wie vor allem von Bal (1994) argumentient worden ist. In diesen Zusammenhang kann das Prinzip der Treue als eine Brücke zwischen dem freiheitlichen Schulz gegen strafende Rechtsantorität und der Sorge fur eine adäquate Strafverfolgung angesehen werden.

Im achten Kapitel werden Aspekte des internationalen offentichen Rechts thematisiert. Die Idee eines internen Zusammenhanges der dret Primzipien von Menschentecht stimmt der im Rahmen des VN-Vertrages aufgestellen Doktrin der Unteilbarkeit der Menschemechte uberein. Die enome Entwicklung und Ausdifferenzierung der Menschenrechte macht die Frage dach dem Vorrangsverhaltnis unumgänglich. Diese Frage wird im Zusammenhang mit der Stellung der Gewissensfreiheit diskutiert. 
Die Entwickiung der Menschenrechte kann als Ausdifferenzienung einer zuerst nur religiös aufgefassten Gewissensfreiheit im Zusammenhang mit einer auf ein friedliches Zusammenleben ausgerichteten gesellschaftlichen Ordmung gesehen werden. Gegen Vemeulen $(1989,1992)$ wird die These vertreten, daß diese Ausdifferenzierung die Funktion der Gewissensfreiheit als Mutter aller Menschenrechte nicht uberflussig gemacht hat. Vermeullen ist dieser Meinung zugetan, weil die Gewissensfreiheit uferlos sei und die Berufung auf das Gewissen gegen jede Beschränkung won Grundrechten eingesetzt werden könne. Vermeulen argumentiert, daß sich die von Artikel 9 erster Absatz des EMRK's unklausuliert verbürgte Gewissensfreiheit ausschyieBlich auf die interne Gewissensfreiheit bezieht. Die vom zweiten Absatz dieses Artikels erlaubte Beschränkung ware anders mämlich nicht verständlich. Diese These stimmt aber nicht mit dem Wortlant des Artikels uiberein und sie folgt auch nicht aus dessen Teilung in zwei Absatze. Vermeulens Arggt vor der Uferlosigkeit des Gewissens ist verwandt mit der Furcht, soziale Rechte würden dem Staat unmögliche Verpflichtungen aufbürden. Im Lichte der These der imneren $A b$ hängigkeit der drei Prinzipien von Menschenrecht erscheint diese Furcht grundsätzlich aber unbegründet. Ein solches Verhältnis würde ja die individuelle Freiheil als allgemeines Recht unmittelbar bedrohen and das Verhältnis der Treue zwischen den Bügern und zwischen dem Staat und seinen Bürgern untergraben. Die These der Prioritait der klassischen Menschenrechte oder der negativen gegenüber den positiven Grundrechtsverpflichtungen des Staates, wird darum von der Autorin nicht vertreten.

Klassische und soziale Menschenrechte können zu sowohl positiven wie negativen Verpflichtungen Anlaß geben. Der Grund für die von der Autorin verworfene These ist, daß die indiwiduelle Freiheit tatsächlich der Ausgangspunkt sein soll, aber, und das ist der springende Punkt, er soll auch immer im Zusammenhang mit den beiden anderen Prinzipien gesehen werden. Letztere sollen ihrerseits wieder in ilarer rückbezogenen Funktion zur Freilheit betrachtet werden. Hierbei sind zwei Beurteilungsstufen zu unterscheiden. Auf der ersten ist zu beurteilen, ob eine als Menschenrecht anerkannte Freiheit beschränkt wird. Auf der zweiten Stufe soll beurteilt werden, ob diese Beschränkung gerechtfertigt werden kann, im Lichte eines ausreichenden positiven Rückbezugs einer Beschränkung auf Freiheit. Dabei spieit Trene wieder eine vermitteinde Rolle zwischen Freiheit und Sorge. So wird in Artikel $137 \mathrm{e}$ des niederlïndischen Strafgesetzbuches im Zusammenhang des Schutzes der öffentlichen Ordnung sachliche Berichterstattung vom Diskriminierungsverbot ausgesondert. Von sachlicher Berichterstattung kann aber nur die Rede sein, wenn dem Berichterstatter, z.B. ein Journalist, auch eine sachliche Absicht zugeschrieben werden kann, d.h. wenn er wie ein zuverlässigel und professioneller Joumalist aufgetreten ist. Wir treffen hier wieder auf die vermittelnde, auf Treue ausgerichtete Rolle des Begriffs "öfrentliche Ordnung".

Der immere Zusammenhang der drei Prinzipien won Menschenrecht, der ihrer allgemeinem Einsetzbarkeit zugrunde liegt, manifestiert sich auch im Rahmen des EG-Rechts. Steyger (1994), die Vemeulen's These des differentiellen Charakters klassischer und sozialer Grundrechte unterschreibt, hat behauptet, daB das Diskriminierungsverbot nach Geschlecht bei der Belohnung von Arbeit, Ausflu3 des klassischen Gleichheitsprinzips ist, und kein soziales Recht. Die Autorin ist der Meinung, daß Steyger's Dichotomie eine Simplifizierung darstelit. Dort, wo der freie Arbeitsmarki micht ausreicht, um tatsachliche 
Ungleichheit auszuräumen, kann dieselbe Bestimmung, als soziales Recht aufgefaßt werden, das den Staat veranlaßt, zu diesem Zweck MaBnahmen zu treffen. Umgekehrt betrachtet Steyger das Recht auf sichere und gesunde Arbeitsverhalltnisse als ein soziales Grundrecht und nicht als ein Menschenrecht. Wo dieses Recht aber unmittelbar im Recht auf körperliche Unversehrtheit fundiert ist, ist das nicht zu verstehen. Auch hier ist es beides. Wo dieser Schutz nicht in Freiheit, d.h. durch arbeitsrechtliche Verträge in ausreichendem Masse zu Stande kommt, muß der Staat kompensierend eingreifen. Steyger's Beschwerde gegen soziale Grundrechte ist politischer Art. Sie fürchtet, daß diese eine anti-denokratische Auswirkung haben könnten. Die Autorin dagegen fürchtet gerade, dals der Staat eine zu große Macht erringen könnte, wenn seine Eingriffe nicht auf Menschenrechte zurïckgefuhrt werden können.

Das EG-Recht ist auch im Zusammenhang mit dem Begriff "öffentliche Ordnung" von Interesse. Steyger"s Dichotomie von Menschenrechten und sozialen Rechten ist besonders brisant im Zusammenhang mit der Gleichstellung von Migranten die keine EGStaatsangehörigen sind. Es ist aber nicht nötig, zur Lösung dieser Frage sich direkt aut Menschenrechtsverträge zu bezichen. Die richterliche Interpretation des Begriffs "offentliche Ordnung" von 48 Absatz 3 des EG-Vertrages zeugt nämlich von einer Auffassung des Begriffes, woraus dessen von der Autorin vertretene allgemeine Einsetzbarkeit und dessen menschentechtliche-vermittelnde Bezug spricht. Er reicht aus, die fragliche Diskrimierung zu verbieten.

Im abschließenden neunten Kapitel wird auf Grund der vorangehenden Untersuchung behauptet, daß die drei Thesen erhärtet worden sind. Danach widmet die Autorin sich noch einmal dem Begriff der Allparteilichkeit. Im Stralprozessrecht problematisch, erscheint er in Verwaltungsrecht gestärkt. Im internationalen Privatrecht wird Allparteilichkeit durch Privatautonomie gefördert, während sie im Vertragsrecht gerade beschränkt wird, wobei ungleiche Machtstellungen A.lparteilichkeit verhindern könnten. Im Verhältnis won Menschenrechten und sozialen Grundrechten besteht ein mangelndes, von der Autorin kritisiertes Verständnis von Allparteilichkeit.

Zuletzt wendet die Autorin sich noch eimmal dem Ausgangsproblem zu: Den Fall der verbotenen Prozession zu Geertruidenberg. Es kann unschwer gezeigt werden, daß ohne konkretie Interessenabwägung zwischen den zur Debatte stehenden Interessen im Lichte der drei Prinzipien von Menschenrecht, eine gerechte Entscheidung nicht möglich ist. Wird eine solche abor vollzogen, dann kann juristisch überzeugend dargelegt werden, daß das Verbot als ungerecht anzumerken ist. 


\section{Literatuurlijst}

- Abas, P., Beperkende werking van de goede trouw, Deventer 1972.

- Alkema, E.A., De betekenis van het EVRM voor de Nederlandise constitutie, in de bundel 40 jaar Europese Conventie voor de rechten van de mens en de Nederlandse rechtsorde. Staatsrechtconferentie 1990, Leiden 1990 , p. 3-35.

- Arendt, H., The Human Condition, Chicago 1958.

- Arendt. H., Vita Activa, Stuttgart 1960

- Ars Aequi, Osmose tussen publiek- en privaatrecht, themanummer Ars Aequi 1987, nr 5, p. $273-372$.

- Asser A.C.Scholten GJ., Algemeen Deel, Zwolle 1974.

- Asperen, G.M. van, De goede maatschappij, Assen 1978.

- Bakker Schut, P.H./ Prakken. T./ Roos. Th. de, Politiek protest in de rechtszaal, in Recht en Kritiek 1984, p. 33-62.

- Bal, P., Dwangcommunicatie in de Rechtszaal, Arnhem 1988.

- Bal, P., Wat draagt Habermas bij tot de ontwikkeling van een discourstheoric van het straf(proces)recht?, Recht en Kritiek 1994, p. 152-169.

- Barenarecht, J.M., Recht als model van rechtwaardigheid, Deventer 1992.

- Barendrecht, J.M., Het constitutionele toetsingsrecht van de rechter, in Handelingen NJY 1992 I, Preadviezen van L. Prakke, T. Koopmans en J.M. Barendrecht, Zwolle 1992, p. 85 172 .

- Bax. C.J., Beginselen van behoorlijk bestuur als ongeschreven rechtsregels, in NJB 1991, p. $779-783$.

- Beekhuis, J.H., Contract en contractswrijheid, rede Groningen, Djakarta 1953.

- Bergh, G. wan den, De democratische Staat en de niet-democratische partijen, rede UvA, Amsterdam 1936.

- Bernstein, R.J., Beyond Objectivism and Relativism: Science, Hermeneutics, and Praxis, Oxford 1983.

- Bers A. van, Twintig jaar kritische maalschappijtheoric, Een kennismaking met Habermas, in Vlaans marxistisch tijdschrift 1984, p. 11-28.

- Blankenbarg, E, De legitimiteit van het recht ligt in wat het doet, in Recht en Kritick 1994, p. $145-151$.

- Blom, T., Zin en systeem, in Tijdschrift voor Sociale Wetenschappen 1986, p. $23-53$.

- Boer. Th. de, De vermaatschappelijking van het intemationaal privaatrech, in NJB 1980. p. 785-796.

- Boer. Th. de t Tussen filosofie en profetie, de wijsbegeerte van Emmanuel Levinas, Bararn 1988.

- Boer, Th. de/Kotting, $R$, President Wijnholt vs President Reagan, in NJB 1982, p. 1177 1186.

- Boonh, H., De openbare orde als grens van het vrij verkeer in de EEG, Alphen aan den Rijn 1977. 
- Bost, R. Openbare orde: en towerspreuk, Beschowwingen naar aanleiding van de Geertruidenberg-arresten, in Mastrichtse wandelingen door het Rech, 10 scripties van de eerste lichting afgestudeenden aan de Faculteit der Rechtsgeleerdheid te Maastricht, 1986, p. $6-20$.

- Bost-Habets, R., Boekbespreking Eskes, in Publiek Domein 1989, p. $337-340$.

- Bost, R., De vrijheid van geweten als fundamenteel rechtsprobleem, Boekbespreking Vemeulen, in Tijdschrift voor Privatrecht 1990, p. 1495-1511.

- Bost, R., Recht als model wan rechtvardigheid, in R\&R 1994, p. 40-47.

- Boven. TH. C. vam, De volkenrechtelijke bescherming van de godsdiensivrijheid, Assen 1967.

- Boven, Th. C. van, Slotopmerkingen, in De toenemende betekenis van economische, socialle en culturele mensenrechten, A.P.M. Coomans e.a. (red), Leiden 1994, p. 140-142.

- Brakel, S. wan, Grondslagen en Beginselen van Nederlands Internationaal Privaatrecht, Zwolle 1953.

- Burg, W. wh der, Het democratisch perspectief, Hnhem 1991.

- Burms, A.Ain, H. de, De rationaliteit en haar grenzen, Leuven/Assen 1986.

- Cohen, M.J., Over hei denken wan juristen, Niewwenhoflezing V, Deventer 1992.

- Coomans, A.P.M., Schendingen van economische, socialle en culturele rechten, in De toenemende betekenis van economische, sociale en culturele mensenrechten, Coomans Heringa/Westendorp (red.), Leiden 1994, p. 59-73.

* Crijms, F.C.L.M., De herziening van artikel 208 van de Grondwet, Het loon van de angst?, In Jeukensbundel 1982 , p. 439 e.v.

- Crombag, H.F.M.Whikerstooth, JL. de/Cohen, M.J, Een theorie over rechterlike beshissingen, Groningen 1977.

- Dumné. JM. van, Drie beginselen van contractenrecht, een boekbeschouwing, in WPNR $5525,1980, \mathrm{p} .458$ e.v.

- Dunné, J.M. van, Verbintenissenrecht in ontwikkeling, Deventer 1987.

- Dworkin, R., Taking rights seriously, Londen 1978.

- Edinga, JW., De model Algemene platselijke verordening in 2000, in Regelmaat $1995 / 1$, p. $11-17$.

- Enschede, Ch., De burger en het recht, Amstendam 1988.

- Eras, J.M.M. De overeenkomst in het international privaatrecht, Den Hag 1928.

- Em, J.H.M. wa, Contract als rechtsbetrekking, Zwolle 1990.

- Eskes. I.A.O. Repressie van politieke bewegingen in Nederland, een juridisch-historische studie over het Nederlandse publiekrechtelike verenigingsrecht gedurende het tijdvak 1798 1988, Zwolle 1988.

- Fhinerman, $C$., De ondeclbaarheid van de rechten van de mens, in De toenemende betekenis van economische, sociale en culturele merscnrechten, A.P.M. Coomans e.a. (red.), Leiden 1994, p. $1-7$.

- Forder, C.., Positicve verplichtingen in het kader van het Europees verdrag tot bescheming van de rechten wan de mens en de fundamentele wrijheden, in NJCM-Bulletin 1992, p. 611. 637. 
- Frijda, N.H., Een psychologische theorie van de emotie, in Gevoel en emotie, M. van Nierop (red.), Delft 1985, p. 73-95.

- Garé, D., Het onmiddellijkheidsbeginsel in het Nederlandse strafproces, Arrhem 1994.

- Garé, D. e.a., Straatsburg: ijkpunt of breekpunt?, NJCM-werkgroep Strafrecht en Mensenrechten, in NJCM-Bulletin 1995, p. 482-503.

- Gerbenzon, P.Algra, N.E, Voortgangh des rechtes: de ontwikkeling van het Nederlandse recht tegen de achtergrond van de West-Europese cultuur, Alphen aan den Rijn 1987.

- Gerbranda, Tj./Kroes, M., De wetgever en de mensenrechten: beschermer of beperker? Enkele aantekeningen naar aanleiding van het Grondrechten Evaluatie Onderzoek, in NJCMBulletin 1994, p. 465-481.

- Gerven, W. van, Beginselen van behoorlijk handelen, Story Scientia, 1983.

- Groenhuijsen, M.S., De criticus bekritiseerd, in NJB 1982, p. 161 a.v.

- Groot, G.R. de, Staatsangehörigkeit im Wandel, Den Haag 1988.

- Gunning. M., Onvolwassen recht, in Nemesis 1994, p. 17-23.

- Hobermas, J., Strukturwandel der Öffentlichkeit (1962), Neuwied 1984/1962.

- Habermas, $J$., Theorie des kommunikativen Handelns, Band I (1981), Frankfurt an Main 1988.

- Habernas, J., Faktizität und Geltung, Frankfurt am Main 1992.

- Haersolte, A. wan, De mens en het zijne, Zwolle 1984.

- Hage, J.C., De objectiviteit van waardeoordelen, in Interne en externe analyses van recht, J.H.M. Klanderman en N.H.M. Roos (red.), Zwolle 1988, p. 49-66.

- Hart, A.C. 't, Recht als schild van Perseus, woordrachten over strafrechtstheorie, Arnhem/Antwerpen 1991.

- Harkamp, A.S., Internationale overeenkomsten en nieuw dwingend recht, in Feestbundel Offerhaus Kring, Deventer 1987, p. 93-104.

- Hortogh, G.A. den, Burgerschap en ongehoorzaamheid, in R.M. Themis 1989, p. 5-33.

- Hasselt, van, Verzameling van Nederlandse statstegelingen en grondwetten, samengesteld door W.J.C. van Hasselt, Alphen aan den Rijn 1987.

- Hazewinkel-Suringa/Remmelink, Inleiding tot de studie van het Nederlandse strafrecht, Alphen aan den Rijn 1996.

- Heringa, A.W.Merheij. N. (red.), Publiekrechtelijke bewegingen, Deventer 1990.

- HimalOlthor, Compendium van het Nederlands vermogensrechi, Deventer 1996.

- Hijmans. J.H., Algemeene Problemen van Internationaal Privatrech, Zwolle 1937.

- Hobbes, Th., The Citizin, Oxford 1983.

- Hobbes, Th., Leviathan (1651), ingeleid door C.B. Macpherson, Penguin 1981.

- Hoeven. J. van der, De drie dimensies van het bestuursrecht, Alphen aan den Rijn 1989.

- Holmaat, R. Tussen miet-verantwoordelijkheid en zorg, in Nemesis 1993, p. $71-80$.

- Janssens, $F$, Beledigende uitlatingen in de media, Opmerkingen naar aanleiding van EHRM 23 september 1994, Series A 289 (Jersild v. Denemarken), in NICM-Bulletin 1995, p. $124-141$.

- Jessumun d'Olweira, H.U., Openbare orde en rechtswergelijking, in 'T Exempel dwinght, Kisch-bundel, Zwolle 1975, p. 239-261. 


\section{Literaturtijst}

- Kluiver, H.J. de, Onderhandelen en privaatrecht, Deventer 1992.

- Kollewijn. R.D. Het beginsel der openbare orde in het internationaal privaatrechi, Den Haag 1917.

- Kotting, R., Extraterritoriale wetgeving, preadvies NVIR, Deventer 1984.

- Krabbe, H. Administratieve Rechtspraak - Bijdrage, Groningen 1.901.

- Krabbe, H., De moderne Staatsidee, Den Haag 1915.

- Kranenburg, F., Eenige opmerkingen over het begrip: "Publieke Orde", Groningen 1895.

- Kranenburg. R., De tegenstelling tussen publiek-en privaatrecht en de ontwerpen tot regeling der administratieve rechtspraak, Leiden/Groningen 1909.

- Krings, H., System und Freiheit, Freiburg/München 1980.

- Langemeijer, G.E, De gerechtigheid in ons burgerlijk vermogensrecht, Zwolle 1985.

- Lauwarars, R.H., Het voorbehoud voor de openbare orde als beperking van het vrije verkeer vam personen in de EEG, in SEW 1978, p. 829 e.v.

- Leijen, A., Profielen van ethiek: van Aristoteles tot Levinas, Muiderberg 1992.

- Levenbach, M.G., De spanning van de kontraktsband, Amsterdam 1923.

- Levinas, E., Het menselijk gelaat, Essays, gekozen en ingeleid door A. Peperzak, Bilthoven 1969.

- Levinus, E. De totaliteit en het oneindige, Essay over de exterioriteit, vertaald door Th. de Boer en Ch. Bremmers, Baarn 1987.

- Levinas, E., Van aangezicht tot aangezicht, 1987.

- Ley. J.N. van dep, Overeenkomsten, in strijd met de goede zeden, Amsterdam 1899.

- Lock, G., Van Hobbes tot Hegel: 1640-1820, in Van Gunsteren/Lock, Politieke theorieenn, Alpen aan den Rijn 1977, p. 56-151.

- Lock, G., Boekbespreking Van der Burg, in R.M. Themis 1992, p. 291-294.

- Lock/Van Gunsteren/Balibar, Sterke posities in de politieke filosofie, Leiden/Antwerpen 1989 , p. $43-57$.

- Locke, J., Two Treatises of Government (1690), Londen 1965.

- Loof-Donker, A.M.F./Peeters, E.M./Van der Tang-van Loenen, P.H., De openbare orde: een te nemen horde? Kanttekeningen bij de wijze waarop de Nederlandse wetgever omgaat met het begrip 'openbare orde' als doelcriterium voor de beperking van grond- en mensenrechten, in NJCM-Bulletin 1994, p. 503-518.

- Loon. J.H.A. van, De wisselwerking tussen internationaal privaatrecht en rechten van de mens, in Grensoverschrijdend privaatrecht, Van Rijn-Bundel, Deventer 1993.

- Macphersor, C.B., The political Theory of Possessive Individualism, Oxford/New York/Toronto 1983.

- Maneschijn, G. e.a., Gelijkheid voor allen - is dat rechtvaardig?, een publikatie van het Nederiands Gespreks Centrum, 1989.

- Meij-van Bruggen, R., Grondrechten als dilemma van overheidsoptreden, Den Haag 1989.

- Meuless, B.M.J. van der, Ordehandhaving, actoren, instrumenten en waarborgen, Deventer 1.993.

- Metwissen, D.H.M. Recht en vrijheid, Inleiding in de rechtsfilosofie, Utrecht/Antwerpen 1982 
- Moller Okin, S., Women and the making of the sentimental family, in Philosophy and Public Affairs 1981, p. 65-8.8.

- Mols, G.P.M.F., Staande de zitting; Een beschouwing over het onmiddellijkheidsbeginsel, Arnhem 1989.

- Neut van der, J.L., Discriminatie en strafrecht, Arnhen 1986.

- Nicolaï. P., Beginselen van behoorlijk bestuur, Amsterdam 1990.

- Nieuwenhuis, J.H., Drie beginselen van contractenrecht, Deventer 1979.

- Nieuwenhuis, J.H, leder het zijne, in R.M. Themis 1988, p. 73 e.w.

- NJCM, IVPBR Special, NJCM-Bulletin 1994, p. 765-944.

- NJCM, Commentaren inzake de versterking van het respect voor economische, sociale en culturele rechten, in NJCM-Bulletin 1994, p. 276-296 en NJCM-Bulletin 1995, p. 255-259.

- Noyon/Langemeijer/Remmelink, Wetboek van Strafrecht, Boek II, titel V, Misdrijven tegen de openbare orde.

- Perrick, F, Politie in Nederland, Zwolle 1982.

- Peters, A.A.G., De emancipatie van de mens, in De rechten van de mens, M.B.W. Biesheuvel en C. Flinterman (red.), Amsterdam 1983, p. 7-22.

- Peters, A.A.G., Recht als kritische discussie, Arnhem 1993.

- Petii, Ch.J.J.M., Overeenkomsten in strijd met de goede zeden, Leiden 1920.

- Polak, M.V. Arbeidsverhoudingen in het Nederlandse international privaatrecht, Deventer 1988.

- Polak, M.V., Internationaal privaatrecht voor het forum van de Hoge Raad, Deventer 1990.

- Posiema, G.J, Equality as membership, in R\&R 1990, p. 155-178.

- Pot, C.W. van der/Donner A.M.Prakke. L., Handboek wan het Nederlandse staatsrecht, Zwolle 1995.

- Pott. H.J., De rationaliteit wan emoties, in Gevoel en emotie, M. van Nierop (red.), Delft. 1985, p. 39-61.

- Préchal. S, Europese mensenrechtenconventie en EEG-recht vergeleken inzake vreendelingentecht, Groningen 1983.

- Raes, K., De post-Rawlsiaanse rechtvaardigheidsdiscussie, Liberalisme, Egalitarisme, Communitarisme, in R\&R 1990, p. 190-210.

- Raes, $K$., Variaties op het verschil-dilemma, in Nemesis 1991, nr 5, p. 5-21.

- Roemmad, B. van, Solidariteit onder vreemden: de rechtstheorie van Jurgen Habermas, in R\&R 1994, p. 120-156.

- Rood, M.G. Over de zwaarte van de rechtenstudie, in NJB 1992, p. 157-160.

- Roos, N.H.M., Recht als tweede orde moraal, in Publiekrechtelijke bewegingen, A.W. Heringa, N. Verheij (red.), Deventer, p. 29-65.

- Rousseau, J.J., Du Contrat Social (1762), Amsterdan 1762.

- Rousseat, J.J., Vertoog van de ongelijkheid, Meppel 1983, vertaling van: Discours sur l'orgine et les fondements l'inegalite parmi les hommes, uit Oeuvres complets III, 1755. 


\section{Lirerandurlist}

- Samkalden, IfWiarda, $G, J$, Algemene beginselen van behoorlijk bestuur, preadviezen, Geschriften wan de Verenging voor Administratie Rech XXIV, Haarlem 1952.

- Sauveplanne, J.G., Elementair Internationaal Privaatrecht, Dewenter 1989.

- Schermers, H.G., Mensenrechten en intemational publiekrecht, in Doorwerking van mensenrechten, P.B. Cliteur en A.P.M.J. Vonken (red.1, Groningen 1993, p. 143-151.

- Schokkenbroek, J.G.C., De openbare orde als beperkingsgrond voor de vrijheid van meningsuiting, in NJCM-Bulletin 1986, p. 3-22.

- Schoordifk, H.C.F. Onderhandelen te goeder trouw, Deventer 1984.

- Schroot. J.C., Privatrechtpubliekrecht, strijd om het primaat, in Publiek Domein 1989 , p. $157-159$.

- Simon, H. Publiekrecht of privatrecht, Zwolle 1993.

- Sieyger, E., Over staatstaken, sociale grondrechten en mensenrechten, in De toenemende betekenis van economische, sociale en culturele mensenrechten, A.P.M. Coomans e.a. (red.). Leiden 1994, p. 8-22.

- Strikwerda, L., Vier ipr dissertaties, in NJB 1988, p. 1444-1448.

- Strikwerda, La, Kroniek van het internationaal privaatrecht, in NIB 1991, P. 1287-1298.

- Strikwerda, L., De hanteerbarheid wan het internationaal privaatrecht, in Grensoverschrijdend privaatrecht, Deventer 1993 , p. 245 e.v.

- Strikwerda, L, Inleiding tot het Nederlands Internationaal Priwatrecht, Groningen 1997.

- Smycken, A.A.H. Administratie of rechter, Arnhem 1910.

- Suyver, J.J.H., Politie in de rechtsonde, Zwolle 1986.

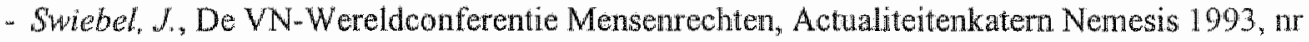
5. p. $30-31$

- Tak, A.Q.C. Overheidsbestuur en Privatrecht, Alpen aan den Rijn 1978.

- Tak, A.Q.C.Bakker R.E. De centrale rol van het willekeurverbod bij de toetsing van overheidshandelen, in Publiekrechtelijke bewegingen, A.W. Heringa/N Verheij (red.), Deventer $1990^{\prime}$ p. $205-218$.

- Velthoven. Th. van, De intersubjectiviteit van het zijn, Kampen 1998.

- Werheth, J.P. Rechtsvinding in het intemationat privastrecht, in Vijhig jaar calvinistische juristenvereniging (1923-1973), p. 83-152.

- Verhew, J.P., De openbare orde als tweesnijdend awaard, rede, Leiden 1978.

- Veweulen, B.P., De wrijheid van geweten, een fundamented rechtsprobleem, Amhem 1989.

- Vermeulen, B.P., Wie bepaalt de reikwijdte van de grondrechten? Preadvies, Handelingen van de vereniging voor wijsbegeerte van het recht, in $R \& R \quad 1992$, p. 1646.

- Viver, C.D. van der, De burger en de zin van strafrecht, Lelystad 1993.

- Was, P. Internationaal privaatrecht in de spiegel van het nieuwe BW, rede VU, Deventer 1989.

- Vonken, A.P.M.J., Het internationale afstemmingsrecht in perspectief, Amhem 1987.

- Wonken, A.P.M. J, De reflexwerking van de mensenrechien op het IPR, in Doorwerking var mensemrechten, P.B. Cliteur en A.P.M.J. Vonken (red.), Groningen 1993, p. 181 e.v. 
- Wochter, de, Ethiek en mensenrechten, Lezing gehouden in de reeks Filosofische Conferenties te Leuven op 18 februari 1987.

- Wentholt, $K$. , Rekening houden met zorgtaken, een ander perspectief voor het gelijkheidsbeginsel, in Recht en Kritiek 1991, p. 367-382.

- Werf, H.G. wan der, Redelijkheid en billijkheid in het contractenrecht, Arnhem 1982.

- Wemer, W., De fundering van het juridisch discours, in Recht en Kritiek 1992, p. 52-72.

- Wiarda, G.J., Drie typen van rechtsvinding, Zwolle 1980.

- Wiarda, J., Nederlands internationaal personen- en familierecht en de openbare orde, in 'T Exempel dwinght, Kisch-bundel, Zwolle 1975, p. $389-408$.

- Wild, A.H. de, De rationaliteit van het rechterlijk oordeel, Deventer 1980.

- Wilthagen, T., Recht in een gesloten samenleving, het debat over reflexief recht en autopoiesis, in Recht en Werkelijkheid 1992, p. 119-138.

- Witte, B. de, Economische, sociale en culturele rechten: de rol van mensenrechten in de rechtsorde van de Europese gemeenschap, in A.P.M. Coomans e.a. (red.), De toenemende betekenis van economische, sociale en culturele mensenrechten, Leiden 1994, p. 8-22.

- Witteveen. W.J., Evenwicht van machten, Zwolle 1991.

- Zaltbonmel, L.K. wan, De betekenis van het recht als systeem, Amsterdam 1993. 



\section{Een nawoord bij wijze van laudatio.}

Nawoorden zijn ongebruikelijk in een proefschrift en al helemal een nawoord wan een promotor. Nog ongebruikelijker dan dat is waarschijnlijk dat een dergelijk nawoord de vorm van een laudatio aanneemt. In dit geval zijn er echter een aantal argumenten om een dergelijk taboe te doorbreken.

Het eerste argument is dat de schrijfster als gevolg van ernstige ziekte haar proefschrift niet in het openbaar kon verdedigen en om die reden wan die verplichting door het College van Decanen van de Universiteit Maastricht is vrijgesteld. Daardoor was het ook niet mogelijk om bij die gelegenheid een laudatio wit te spreken.

Het tweede argument is dat de schrijfster en ik als gevolg van hatar ziekte niet in staat zijn geweest om alle in het kader van de dissertatie voorgenomen kwesties uit te diepen. $1 k$ wil dit nawoord gaarne gebruiken om aan te geven om welke kwesties het hier gaat.

Het derde argument hangt samen met de eerste twee. De schrijfster is zelf ook niet meer in staat aan een eventueel naar aanleiding van haar boek nog to ontstaan debat deel te nemen. Maar de inhoud van het boek is zodanig waardevol, dat daartoe alle analeiding is.

De waarde van dit boek is van zowel rechtstheoretische als van positiefrechtelijke aard. Deze twee kwaliteiten zijn volgens de in dit boek verdedigde rechtsvindingstheorie onverbrekelijk met elkaar verbonden. De rechtstheoretische waarde valt weer in twoeën uiteen. De eerste is een waarde binnen het ramwerk van de theorie van de communicatieve rationaliteit van Jürgen Habermas. In dit boek wordt uiteengezet dat Habermas zelf zijn theorie voor het recht alleen maar nader had uitgewerkt als een theorie van de democratie. Dit was echter betrekkelijk voor de hand liggend, aangezien het idee van een relatie van een rationeel debat en democratische politiek al twee eeuwen geleden door Kant en vijftig jaar geleden door Popper was gepresenteend. Daarnaast is er aan Habermas' theorie door Robert Alexy een theorie van de juridische argumentatie aangeknoopt die de goedkeuring van Habermas heeft kunnen wegdragen. Maar deze theorie is van procedurele alard en is nauwelijks meer dan cen toepassing van een algemene theorie van praktisch argumenteren op het recht. In dit boek wordt, en dat is wel behoorlijk origineel, aan Habermas een materiele rechtsvindingstheorie ontleend. Daarbij wordt in het tweede deel van het boek aangetoond dat deze theorie zich op wruchtbare en kritisch-constructieve wijze lat toepassen op het positieve recht. Voor Habermasianen moet het bevitijdend nieuws zijn dat de theorie van de communicatieve rationaliteit thans niet meer van een zekere steriliteit kan worden beschuldigd.

Door critici van Habermas, zoals schrijver dezes, kan echter de vraag worden opgeworpen in hoeverre Habermas' theorie een noodzakelijke voorwaarde is voor de rechtsvindingstheorie die hier is voorgesteld. Het idee dat in ons recht de individuele vrijheid het uitgangspunt is en dat het recht ertoe dient om deze vijheid te waarborgen, zowel rechtstreeks, door het gedrag van andere burgers en dat van de overheid berekenbaar te maken, 
als indirect, door sociale, materiêle en ecologische condities te helpen scheppen waaronder praktische autonomie pas mogelijk is, is een inzicht waarvoor op zichzelf genomen geen theorie van communicatieve rationaliteit nodig is. Daarbij komt dat de theorie van de communicatieve rationaliteit wan idealistisch-rationalistische huize is. Een wan de bekende kritieken op Habermas is dat er vormen wan zinvolle communicatie zijn, zoals het geven wan opdrachten, die spelen in sociale relaties zoals, gedeeltelijk althans, het onderwijs, die niet of niet volledig kurnen voldoen aan de rationaliteitswereisten die Habermas verbindt met open communicatie, maar die in sociaal-functionele zin zeer wel te rechtvaardigen zijn. Filosofisch gesproken kan de radicale, door Kant noch Habermas beantwoorde vraag worden opgeworpen: waarom rationeel zijn? Sociaal-politiek gezien is de vraag waarom de samenleving geheel en al zou dienen te voldoen aan het model van communicatieve rationaliteit. Een dergelijke vraag slaat natuurlijk ook terug op het recht.

Een tweede vraag betreft de verhouding van recht en democratie. In dit boek wordt duidelijk gekozen voor een fundering en een begrenzing van de democratie in het recht. Maar daarmee is de wraag nog onvoldoende beantwoord. Het gegeven dat de rechterlijke controle op de juridische legitimatie van de democratie zelfs in landen die, anders dan het onze, gezegend zijn met constitutionele rechtspraak volgens de maatstaven van de rechtstheorie die hier ontwikkeld is, nog tamelijk beperkt than worden genoemd, is daarbij naar mijn mening nog het geringste bezwaar. Een groter bezwaar lijkt me dat we met de fundering van het recht in het idee van mensenrecht, nog geenszins een einde lijken te hebben gemaakt aan de verschillen in politiek-ideologisch gekleurde opvattingen daarover. Deze kunnen we grof gezegd onderscheiden in een iberale -, een christen-democratische en een sociaal-democratische visie. Van de christen-democratische visie zou wellicht nog gezegd kumnen worden dat deze als gevolg van haar christelijk-communeautaristisch karakter niet in overeenstemming is te brengen met Habermas' theorie van de communicatieve rationaliteit. Voor de sociaal-democratische wisie kan dat echter niet worden gezegd. De actuele vraag die zich dan in deze "end of ideology/history"-periode opdringt, is of de verschillen van opvatting tussen liberalen en sociaal-democraten gereduceerd kumnen worden tot verschil van inzicht over de effectiviteit en kosten-baten van verschillende maatregelen, terwijl over de witeindelijke doeleinden van de politiek geen verschil van mening bestaat, of dat ze dieper gaan en ook aan de sociaal-democratische visie cen flinke closis idealisme a la Beethovens Negende is verbonden. Bij de sociaal-democraat Habermas bestaat daar geen twijfel aan. Hij leert immers dat het emancipatoire ideaal onderdeel is van communicatieve rationaliteit. Dit impliceert echter de legitimatie van staatsdwang ook daar waar een liberaal van mening is dat private en publieke autonomie van een ieder al voldoende gewaarborgd zijn. Het gevaar van patemalistisch utopisme, onlangs nog zo knap geanalyseerd door onze collega's Crombag en Van Dun in hun boek "De utopische werleiding", ligt dan op de loer. Het vrijheidsideaal heeft in de geschiedenis al heel wat onderdrukking weten te legitimeren.

Deze politieke kritiek op Habermas laat zich echter ook theoretisch formuleren. De betrekkelijke steriliteit van Habermas' theorie zoals hij die zelf ontwikikeld heeft, houdt m.i. ook verband met het feit dat hij aanneemt dat zich onder de assumptie van de norm van de "Herrschaftsfreiheit" niets naders laat zich zeggen over de vorm van de denocratic. Zo neemt hij zonder meer aan dat de bestaande staatsvorm van het publieke gezag en de 
daarbij aanshitende vorm van de politieke partij met hun integrale politieke programma"s, acceptabel zin. Anders gezegd, hij heeft geen staatstheorie ontwikkeld. Evenzo heeft hij geen theorie van de fundamentele rechtsinstituten, eigendom en contract, het strafrecht, de belastingen, de sociale zekerheid e.d. En alleen op die manier zou hij tot een positief begrip kunnen komen wan de verhouding tussen leef- en systeemwereld, waarvan hij meent dat het recht er tussen "bemiddelt". Zeker, maar hoe dan precies?

Deze en dergelijke vragen komen in het kader van de rechtsvindingstheorie, ook bij dic van de schrijfster, terug als die van de verhouding van rechter, wet en politiek. Dat neemt echter volstrekt niet weg dat ik haar theorie verwelkom als een aanzieniijke verrijking van de rechtswindingstheorie, zowel in kentheoretisch, in empirisch, als ook in kritisch opzicht. In kentheoretisch opzicht geeft haar theorie inzicht in wat door hermeneutische theoretici, zoals Josef Esser bijvoorbeeld, altijd tamelijk vaag is aangeduid als het "Vorverständnis" van de rechter, als "de hermeneutische cirkel tussen norm en feit" en als "die Sache Recht". Hieraan wordt door schrijfster inhoud gegeven door het idee dal de rechter op zoek is en dient te zijn naar de vrijheidsbelangen, het belang van de voorspelbaarheid van gedrag in rechte en de bescherming van sociaal zwakkeren. Dit laatste niet in een politieke zin, maar in relatie tot de mogelijkheid van autonomie naar juridische maatstaven. Deze theorie van het kentheoretisch zoeklicht van de rechter en wellicht van de jurist in het algemeen, laat zich zowel toepassen op de wijze waarop deze de betekenis van her bestaande recht reconstrueert, als op de wijze warop hij feiten selecteert in het concrete geval, alsmede op de wisselwerking tussen de constructie van het recht en van de feiten. Daarmee krijgt de theorie ook een empirische relevantie. Het laat zich m.i. tol op zekere hoogte empirisch onderzoeken of rechters in enigszins gecompliceerde gevallen aldus te werk gaan. Ook laat de kwaliteit van rechters zich aldus enigszins meten met empirische middelen. Of een rechter goed kan communiceren, of hij inzicht heeft in het leefwereldrechtsgevoel van partijen en de rechtsvaardigheidsmaatstaven van het rechissysteem en tenslotte, of hij gevoel heeft voor en inzicht in sociale verhoudingen zoals die zich in de matschappelijke werkelijkheid voordoen, zijn zaken die zich tot op grote hoogte empirisch laten vaststellen. Ook in kritisch opzicht heef de theorie van Rie Bost m.j. grote waarde. Immers, als cen rechter zich werkelijk communicatief opstelt zal hij zijn eventuele oordeel dat de onrechtivaardig is, niet onder stoelen of banken moeten steken, maar hiervan kennis dienen te geven, ook al zal hij zich in de reggel onderwerpen aan het gezag van de wet.

Met dit alles wil ik de theorie van de schrijfster ook nog in cen vierde opzicht prijzen. M.j. heeft de theorie een grote educatieve warde. Gesteld dat het een adequate theoric wan de rechtswinding is of althans heel wezenlike aspecten daarvan dekt, dan laat deze zich ook toepassen in het onderwijs, zowel in het zuiver cognitieve onderwijs als in het vaardighedenonderwijs. Daarmee heeft de schrijfster mijns inziens cen essentiele bijdrage geleverd aan de mogelijkheid de idealen te realiseren die ooit ten grondslag lagen aan de onderwijsvemieuwingen van de Maastricht faculteit waarvan zij student en medewerker is geweest. Als zodanig was zij zowell buitengewoon autonoom, trouw en zorgzatm in geestelijk en praktisch opzicht. 
Nawoord bij wije van laudatio

Daardoor en door thaar boek heeft zij voor mij en, naar ik stellig hoop ook voor anderen, binnen de begrenzingen van het ondermaanse eeuwigheidswaarde gekregen.

Maastricht, januari 1999.

N.H.M. Roos 